\title{
Dietary Determinants of Obesity
}

Citation for published version (APA):

Du, H. (2009). Dietary Determinants of Obesity. [Doctoral Thesis, Maastricht University]. Universitaire Pers Maastricht. https://doi.org/10.26481/dis.20091211hd

Document status and date:

Published: 01/01/2009

DOI:

10.26481/dis.20091211hd

Document Version:

Publisher's PDF, also known as Version of record

\section{Please check the document version of this publication:}

- A submitted manuscript is the version of the article upon submission and before peer-review. There can be important differences between the submitted version and the official published version of record.

People interested in the research are advised to contact the author for the final version of the publication, or visit the DOI to the publisher's website.

- The final author version and the galley proof are versions of the publication after peer review.

- The final published version features the final layout of the paper including the volume, issue and page numbers.

Link to publication

\footnotetext{
General rights rights.

- You may freely distribute the URL identifying the publication in the public portal. please follow below link for the End User Agreement:

www.umlib.nl/taverne-license

Take down policy

If you believe that this document breaches copyright please contact us at:

repository@maastrichtuniversity.nl

providing details and we will investigate your claim.
}

Copyright and moral rights for the publications made accessible in the public portal are retained by the authors and/or other copyright owners and it is a condition of accessing publications that users recognise and abide by the legal requirements associated with these

- Users may download and print one copy of any publication from the public portal for the purpose of private study or research.

- You may not further distribute the material or use it for any profit-making activity or commercial gain

If the publication is distributed under the terms of Article $25 \mathrm{fa}$ of the Dutch Copyright Act, indicated by the "Taverne" license above, 


\section{Dietary Determinants}

of

Obesity 
Cover design: Huaidong Du and Esther van Hoevelaken - Wilbrink Layout: Huaidong Du

Printed by: GVO drukkers \& vormgevers B.V. I Ponsen \& Looijen, Ede

(C) Huaidong Du, 2009

Thesis Maastricht University-173 pages-with references and summary in English, Dutch and Chinese.

ISBN: 978-90-9024757-1 


\title{
Dietary Determinants of
}

\section{Obesity}

\author{
DISSERTATION
}

to obtain the degree of Doctor at

the Maastricht University,

on the authority of the Rector Magnificus,

Prof. dr. G.P.M.F. Mols,

in accordance with the decision of the Board of Deans.

To be defended in public on

Friday December 11th 2009 at 10:00

by

$$
\begin{aligned}
& \text { Huaidong Du } \\
& \text { 木土 怀东. }
\end{aligned}
$$

Born on February $24^{\text {th }}$ 1971, Liaoning Province, China

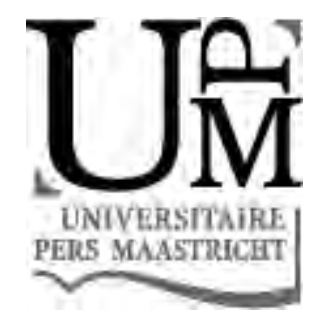




\section{Promoters/Supervisors:}

Prof. dr. ir. W. H.M. Saris

Prof. ir. E. J.M. Feskens (Division of Human Nutrition, Wageningen University)

\section{Co-promoter/Co-supervisor:}

Dr. D. L. van der A (Center for Nutrition and Health, National Institute for Public Health and the Environment, RIVM)

\section{Assessment Committee:}

Prof. dr. E. C.M. Mariman (Chairman)

Prof. dr. ir. M. van Baak

Prof. dr. ir. P. van den Brandt

Prof. dr. ir. C. de Graaf (Division of Human Nutrition, Wageningen University)

Dr. ir. T. L.S. Visscher (VU University Amsterdam)
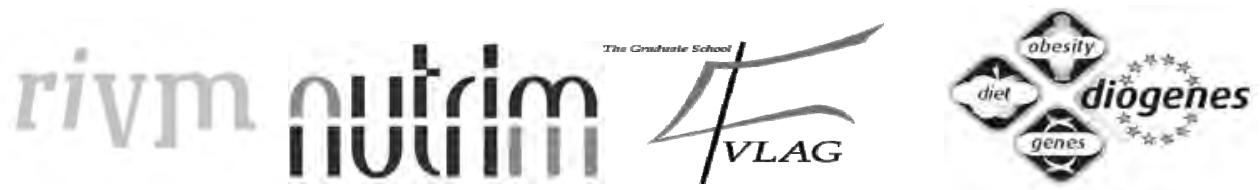

The research presented in this thesis was performed within the Netherlands National Institute for Public Health and the Environment (RIVM) and NUTRIM School for Nutrition, Toxicology and Metabolism of Maastricht University, which participates in the Graduate School VLAG (Food Technology, Agrobiotechnology, Nutrition and Health Sciences) of Wageningen University; and was financially supported by the pan-European program DiOGenes, which is the acronym of "Diet, Obesity and Genes" (Contract no. Food-CT-2005-513946). 


\section{Contents}

Chapter $1 \quad$ General introduction 7

Chapter 2 Dietary glycemic index: a review of the physiological mechanisms 23 and observed health impacts

Acta Cardiol. 2006;61(4):383-397

Chapter $3 \quad$ Glycemic index and glycemic load in relation to food and nutrient 45 intake and metabolic risk factors in a Dutch population

Am J Clin Nutr. 2008;87(3):655-661

Chapter $4 \quad$ Reproducibility and relative validity of dietary glycemic index and glycemic load assessed by the Dutch EPIC FFQ

Br J Nutr. 2009;102:601-604

Chapter 5 Dietary glycemic index, glycemic load and subsequent changes of weight and waist circumference in European men and women Int J Obes. epublished 25 August 2009

Chapter 6 Dietary energy density in relation to subsequent changes of weight and waist circumference in European men and women

Plos ONE. 2009;4(4):e5339

Chapter $7 \quad$ Fiber intake in relation to subsequent changes of weight and waist circumference in European men and women

Am J Clin Nutr. 2009; In review

Chapter $8 \quad$ Genetic polymorphisms in the hypothalamic pathway in relation to subsequent changes of weight and waist circumference

In preparation

Chapter 9 General discussion

Summary

Samenvatting

摘要

Acknowledgements

About the Author 



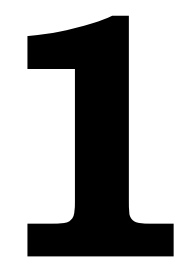

\section{General introduction}

Obesity, and to a lesser extent also overweight, is characterized as an excessive accumulation of energy in the form of body fat. Overweight and obesity have reached epidemic proportions globally and the most recent estimate indicates that more than 1 billion adults worldwide are overweight, of whom at least 300 million are obese. ${ }^{1}$ This poses a serious health problem because overweight and obesity lead to adverse metabolic effects on blood pressure, blood lipids, and insulin resistance, consequently increasing the risk of chronic diseases such as type 2 diabetes, cardiovascular disease (CVD), hypertension, stroke, and certain forms of cancer. According to the World Health Report 2002, approximately 58\% of diabetes, $21 \%$ of ischemic heart disease and $8-42 \%$ of certain cancers are attributable to a BMI above $21 \mathrm{~kg} / \mathrm{m}^{2}{ }^{1}$

The most commonly used quantitative measurement of adiposity is the body mass index (BMI), defined as the weight in kilograms divided by the square of the height in meters $\left(\mathrm{kg} / \mathrm{m}^{2}\right)$. Currently, a BMI $\geq 25 \mathrm{~kg} / \mathrm{m}^{2}$ is defined as overweight, and a $\mathrm{BMI} \geq 30 \mathrm{~kg} / \mathrm{m}^{2}$ as obese. Waist circumference is also widely used to measure obesity, especially abdominal obesity. A waist circumference $\geq 102 \mathrm{~cm}$ in men or $\geq 88 \mathrm{~cm}$ in women is defined as abdominal obesity or central obesity. ${ }^{2}$

\section{Risk Factors for Weight Gain}

One of the few non-controversial facts about obesity is that weight is only gained when energy intake exceeds energy expenditure for a prolonged time period. Our current environment is characterized by an essentially cheap and unlimited supply of convenient, high palatable, energy-dense foods, coupled with a lifestyle prohibiting a sufficient level of physical activity, due to the invention of cars, washing machines, televisions, internet, etc. Such environment promotes a positive energy balance. In addition, with human evolution, our human being has developed excellent physiological defenses against the energy deficiency and has become very efficient in preventing weight loss. However, we are still relatively ineffective in preventing excessive weight gain in an environment where food is abundant. 


\section{Dietary factors}

A high total energy intake is the main driver of higher body weights in modern populations. ${ }^{3}$ Many dietary composition factors and dietary behaviors are associated with energy intake, and thereby with weight gain and obesity. ${ }^{4,5}$ In 2003 , the joint WHO/FAO expert consultation report on diet, nutrition and the prevention of chronic diseases summarized the strength of evidence of factors influencing weight gain and obesity. ${ }^{6}$ The diet-related factors are listed in Table 1-1 and are briefly discussed hereafter.

\begin{tabular}{|c|c|c|c|}
\hline Evidence & Decreased risk & No relationship & Increased risk \\
\hline Convincing & $\begin{array}{l}\text { High dietary intake of } \\
\text { dietary fiber }{ }^{+}\end{array}$ & & $\begin{array}{l}\text { High intake of energy-dense } \\
\text { micronutrient-poor foods } \ddagger\end{array}$ \\
\hline Probable & Breastfeeding & & $\begin{array}{l}\text { High intake of sugar-sweetened soft } \\
\text { drinks and fruit juices }\end{array}$ \\
\hline Possible & Low glycemic index foods & $\begin{array}{l}\text { Protein content } \\
\text { of the diet }\end{array}$ & $\begin{array}{l}\text { - Large portion sizes } \\
\text { - High proportion of food prepared } \\
\text { outside the home (developed } \\
\text { countries) } \\
\text { - "Rigid restraint/periodic } \\
\text { disinhibition" eating patterns }\end{array}$ \\
\hline Insufficient & Increased eating frequency & & Alcohol \\
\hline \multicolumn{4}{|c|}{$\begin{array}{l}\text { * Strength of evidence: the totality of the evidence was taken into account. The World Cancer Research Fund } \\
\text { scheme was taken as the starting point but was modified in the following manner: randomized controlled trials } \\
\text { were given prominence as the highest ranking study design (randomized controlled trials were not a major } \\
\text { source of cancer evidence); associated evidence and expert opinion was also taken into account in relation to } \\
\text { environmental determinants (direct trials were usually not available). } \\
\text { + Specific amounts will depend on the analytical methodologies used to measure fiber. } \\
\text { ‡Energy-dense and micronutrient-poor foods tend to be processed foods that are high in fat and/or sugars. Low } \\
\text { energy-dense (or energy-dilute) foods, such as fruit, legumes, vegetables and whole grain cereals, are high in } \\
\text { dietary fiber and water. }\end{array}$} \\
\hline
\end{tabular}

\section{Dietary fiber}

Dietary fiber is defined as the edible parts of plant foods that are resistant to digestion and absorption in the human small intestine with complete or partial fermentation in the large intestine. It can facilitate body weight control through different physiological mechanisms.7 Firstly, fiber rich foods tend to be more satiating due to their relatively low energy density and palatability as compared to low fiber foods. Secondly, dietary fiber, especially soluble fiber, could increase the viscosity of diets and slow down the gastric emptying and digestion, thus stimulating the release of gut hormones and promote satiety. In addition, dietary fiber could provide a mechanical barrier to the enzymatic digestion of other macronutrients such as fat and starch in the small intestine. Moreover, the slower digestion and absorption rate of carbohydrates in high fiber foods would lead to a reduced postprandial blood glucose response, which increase satiety and, over a 
long term, could improve insulin sensitivity and influence fuel partitioning to favor fat oxidation. ${ }^{7}$ Although not completely consistent, findings in general support the beneficial role of dietary fiber in the regulation of body weight. ${ }^{8-10}$ Therefore, the WHO ranked the evidence for a beneficial role of dietary fiber in obesity control as "convincing" (Table 1-1).

\section{Energy density (ED)}

Energy density (ED) is defined as the amount of available energy per unit weight of foods or meals $(\mathrm{kJ} / \mathrm{g}$ or $\mathrm{kcal} / \mathrm{g}){ }^{11}$ Experimental data convincingly show that people tend to eat a similar volume of food to feel satiated, and, accordingly, consuming energy-dense foods could cause passive over-eating in terms of energy.12 Furthermore, energy-dense foods, usually high in fat and low in fiber, tend to be highly palatable and stimulate over-eating. ${ }^{13}$ It is believed that the general accepted harmful impact of high fat diets on fat mass accumulation is primarily mediated by dietary ED. Several intervention studies among overweight and obese subjects consistently demonstrate that ED reduction is associated with weight loss. ${ }^{14-16}$ Therefore, the evidence of a positive relationship between high intake of energydense foods and weight gain and obesity was classified as "convincing" (Table 1-1).

\section{Breast-feeding}

The protective effect of breast-feeding against childhood obesity has been reported by several observational studies. ${ }^{17-19}$ The main explanations include infants fed with breast-milk consume lower amounts of total energy and protein as compared to infants fed with formula milk; bioactive substances in breast-milk could inhibit adipocyte differentiation; infants fed with breast-milk develop the ability of regulating food intake early; ${ }^{20}$ and the early exposure of breast-milk flavor could enhance the infants' enjoyment of a wide variety of flavor in later life. ${ }^{21}$ On the other hand, formula-fed infants are often forced to finish the bottle, leading to an excessive consumption of energy and protein. Also, the higher protein content of formulas could stimulate the secretion of insulin therefore stimulating fat deposition and leading to the early development of adipocytes.22 However, results from the first published large randomized trial did not provide evidence about the protective role of breast-feeding. ${ }^{23,24}$ Therefore, the evidence on the protective role of breastfeeding in obesity prevention was viewed as "probable" (Table 1-1).

\section{Sugar-sweetened beverages}

Sugar-sweetened beverages generally contain a large amount of liquid energy, which is poorly compensated and may result in excess energy intake..$^{25}$ In addition, added sugars in the sugar-sweetened beverages are absorbed rapidly, which may promote visceral fat accumulation due to the insulin resistance and increased de novo hepatic fatty acid synthesis caused by the added sugars. ${ }^{26,27}$ Increased consumption of sugar-sweetened beverages, mainly soft drinks and fruit juices, are considered as a 
main driving force for weight gain and obesity, especially among children and adolescents. ${ }^{28}$ Although large high-quality clinical trials are lacking, the evidence in general support that consumption of sugar-sweetened beverages is a "probable" risk factor for obesity. ${ }^{29}$

\section{Glycemic index and glycemic load}

The glycemic index (GI) is a quantitative measure of carbohydrate quality based on the blood glucose response after consumption. ${ }^{30}$ Glycemic load (GL) measures the entire blood glucose-raising potential of dietary carbohydrates and is calculated as the product of GI and total carbohydrates. ${ }^{31}$ It has been suggested that low GI or GL diets can help to prevent body weight gain and stimulate weight loss. ${ }^{32}$ This is because the mild blood glucose and insulin response following a low GI or GL diet consumption could stimulate a higher satiation and satiety, thus leading to a decrease in energy intake, ${ }^{33}$ regulate energy partitioning resulting a reduced fat storage, ${ }^{34}$ and limit the decrease of resting metabolic rate under energy restriction. ${ }^{35,}$ ${ }^{36}$ However, findings in the literature are inconsistent. For example, a Cochrane review $^{37}$ of six randomized controlled trials (RCTs) has concluded that low GI and low GL diets are more effective in promoting body fat loss $(\sim 1 \mathrm{~kg}$ more $)$ than comparison diets, but studies published thereafter have not been able to consistently confirm this finding. ${ }^{38-41}$ Findings from large prospective cohort studies are inconsistent as well. For example, in the SEASONS study, GI, but not GL, has been positively associated with a change in body mass index (BMI ${ }^{42}$. In the Danish arm of the MONICA project, low GI diets have been associated with a lower weight and waist circumference gain in women but not in men. ${ }^{43}$ The evidence for GI was rated as "possible" in the WHO/FAO expert consultation report and more studies are needed to establish the association with certainty.

\section{Protein intake}

Protein has a higher satiety value than iso-energetic quantities of other macronutrients, and therefore higher protein intake could decrease total energy intake. ${ }^{44}$ Also, protein has a greater thermogenic effect and may therefore result in an increased energy expenditure. ${ }^{45}$ However, data from the USA show that the consumption of protein, both at absolute level and as percentage of total energy intake, has remained relatively stable during the past decades, while the obesity prevalence has increased dramatically. This secular trend data do not support the hypothesis that protein plays an important role of in the development of obesity. ${ }^{46,47}$ Most of the earlier observational studies even suggested a positive relationship between protein intake and adiposity among adults. ${ }^{48,} 49$ Also, high protein intake early in life is associated with an increased risk of childhood obesity. ${ }^{50}$ Therefore, the $\mathrm{WHO} / \mathrm{FAO}$ expert consultation reckoned that protein content of diet "possibly" has no independent role in obesity. More recently, some researchers proposed the protein leverage hypothesis, ${ }^{51}$ which means that the body must be supplied with a 
certain level of dietary protein. When a protein-rich diet is consumed, this demand can be easily reached with a lower level of fat and carbohydrate thus total energy intake, otherwise a higher amount of total energy must be consumed to obtain enough protein. Furthermore, several recent studies have observed an inverse association between protein intake and obesity. ${ }^{52,53}$

\section{Portion size}

Larger portion size is often accompanied by a higher total energy content, and thus could contribute to weight gain. ${ }^{54-56}$ Large portion sizes served at restaurants and produced by manufactures have been commonly blamed as one of the important factors in the rising prevalence of obesity. ${ }^{57}$ However, the influence of portion size on food intake may vary by age ${ }^{58}$ and weight status, and may also depend on the energy density of the foods, because it is "possible" that consumption of a larger portion of lower energy dense foods, such as fruits and vegetables, is protective against weight gain. .5

\section{Eating outside home}

Foods prepared at restaurants, especially fast food restaurants, are often of lower nutritional quality and have higher fat and energy contents than foods eaten at home. ${ }^{59}$ Individuals who eat more fast foods tend to have higher intake of energy, fat, and soft drinks, and lower intake of dietary fiber, fruits and vegetables. ${ }^{60}$ In addition, portion sizes served at restaurants are often larger and the palatability and variety of restaurant-prepared foods are often increased. ${ }^{57}$ These factors may contribute to an increased energy intake subsequently leading to obesity. ${ }^{57,61}$ Due to the limited number of studies have been conducted on this topic, the WHO categorized the evidence for a positive association between eating out of home and obesity as "possible".

\section{Rigid restraint and habitual disinhibition}

Restraint is the conscious restriction of food intake to control body weight. Disinhibition is the tendency to overeat in response to external stimuli, such as when a palatable food is available or under emotional distress. Rigid restraint and habitual disinhibition are the most important cognitive behaviors predicting weight gain and obesity in adults.62-64 Although data from intervention studies are lacking, it is "possible" that these psychological parameters of eating habits are positively related to weight gain and obesity.

\section{Eating frequency}

In comparison to eating infrequently (gorging), eating frequently (nibbling) is associated with metabolic advantages including reduced serum levels of total cholesterol, LDL cholesterol, and insulin. ${ }^{65}$ Eating frequently may increase food induced thermogenesis and decrease the efficiency of energy utilization. Frequent 
meals may also suppress hunger and reduce overeating. However, evidence suggesting a beneficial role of increasing meal frequency on preventing obesity is "insufficient" ${ }^{66,67}$ Standardized definitions, e.g. how to define an eating occasion or a meal, are needed, not only for improving the quality of findings in this field but also for providing public recommendations.

\section{Alcohol intake}

Alcohol is a form of liquid energy and research revealed that dietary compensation for liquid energy is less precise. Therefore, over-consumption of total energy might follow after alcohol intake. ${ }^{25}$ In addition, alcohol cannot be stored in the human body therefore it must be preferentially oxidized and thereby results a suppressed oxidation of other macronutrients especially fat. Observational studies have demonstrated mixed associations between alcohol intake and weight gain or obesity status, ${ }^{62,} 68-70$ and the observed associations might be secondary to the associations between obesity and other risk factors, such as poor eating behavior, physical inactivity, and low dietary quality. ${ }^{62},{ }^{69}$ Currently there is "insufficient" evidence suggesting that alcohol consumption is a risk factor for obesity.

\section{Other dietary factors}

Many other dietary factors have been suggested to play a role in regulating energy intake and body weight, such as the intake of whole-grain,,$^{71}$ fruits and vegetables, ${ }^{72}$ and calcium, ${ }^{41}$ total and different types of fat, ${ }^{73}$ and a "prudent" type of dietary patterns. ${ }^{74}$ These factors have been hypothesized to reduce obesity, but evidence is inconclusive and they may also work through the factors indicated above.

\section{Physical activity}

As mentioned earlier, overweight and obesity can only result from a positive energy balance, where energy intake exceeds energy expenditure for a prolonged period of time. Although basal metabolic rate accounts for the majority of total energy expenditure, differences in energy expenditure between individuals are largely determined by the differences in physical activity..$^{75}$ Several large studies have shown that the risk of weight gain is greater among individuals with a sedentary lifestyle as compared to those engaged in regular physical exercises. For example, in a cohort study of over 15,000 US adults, physical activity over 10 years has been inversely associated with weight gain. ${ }^{75}$ In a recent cross-sectional analysis of data from about 400,000 European adults, physical activity has been inversely associated with BMI status. ${ }^{76}$ Evidence from randomized controlled trials also indicate that participating physical activity programs during a dietary-induced weight loss could enhance the likelihood that the weight loss will be maintained. ${ }^{77}$

\section{Other newly detected determinants of obesity}

Early life programming 
Over the past decade, the detrimental effects of poor fetal growth on the development of obesity in later life has become clear. ${ }^{78}$ These effects could be further increased by accelerated postnatal growth. ${ }^{79}$ Accumulating evidence suggests early life programming plays an important role in long term metabolic health. For example, data from Dutch Hunger Winter Families Study indicate that maternal malnutrition in early pregnancy may predict later obesity in both men and women. ${ }^{80,}{ }^{81}$ One plausible mechanism for this effect relates to changes in the expressions of genes which are involved in the regulation of energy balance. In addition, epigenetic mechanisms may contribute to these changes in gene expression. ${ }^{82}$

Quantity and quality of sleeping

Chronic sleep deprivation is increasingly common in modern societies. Interestingly, this has been developing over the same period as the recent epidemic of metabolic conditions including obesity and diabetes. A number of epidemiological studies have been published relating short sleeping duration with more weight gain and obesity. ${ }^{62}, 83,84$ In experimental studies, sleep restriction impaired glucose tolerance and insulin sensitivity, decreased leptin levels and increased levels of the appetite-stimulating hormone ghrelin..$^{85}$ Recently, marked alterations in glucose metabolism and insulin sensitivity were also observed after experimental induction of a high degree of sleep fragmentation and low amounts of slow wave sleep, without changes in sleep duration. ${ }^{86}$ This result indicates that reduced sleep quality per se may also play a role in the pathophysiology of obesity-related risk factors.

\section{Environmental temperature}

The importance of the brown adipose tissue in adaptive thermogenesis, due to the expression of uncoupling protein-1 in the mitochondria, and the regulation of body weight have been proven in animal studies. ${ }^{87}$ However, it was generally thought that brown adipose tissue is only present in infants and has negligible physiologic relevance in adult humans. Recently, several studies have observed that functionally active brown adipose tissue is presented in adult humans, cold exposure can stimulate brown adipose tissue activity, and the amount and activity of brown adipose tissue is inversely correlated with BMI. 88,89 These findings imply that a slightly lower environmental temperature, or stimulated brown adipose tissue activity, could increase adaptive thermogenesis, thus facilitating body weight control. .90

\section{Gene-environment interaction}

Because the genetic background of humans is relatively constant over several generations, it seems unlikely that the recent rise in the prevalence of obesity has been triggered by changes in our genome. However, the susceptibility to obesity is largely determined by our genes. Within any given environment, an individual's becoming obese is not a certainty, but an event that occurs with a certain probability. 
In other words, an individual's body weight and body composition are determined by interactions between the environment and genetics. ${ }^{91}$ For example, the Pima Indians living in Arizona have a much higher incidence of obesity than the rest of the US population and their genetic kindred in the Sierra Madre mountains of Northern Mexico. ${ }^{22}$ Twins, adoptees and migrants have also provided good experimental settings for testing these interactive relationships. The results of these studies emphasize the importance of both environmental and genetic factors in the pathogenesis of obesity. Similar interactions between genes and environments have been suggested by observational studies in other populations also. For example, a study among Japanese men has demonstrated an interaction between a missense variant in the interleukin 6 receptor gene and dietary energy intake influencing abdominal obesity. ${ }^{93}$ In the Danish population-based Inter99 study, a low physical activity has been associated with an attenuated effect of a single nucleotide polymorphism (SNP) of the fat mass and obesity-associated (FTO) gene on body fat accumulation..$^{94}$ The interaction between dietary fat and the Pro12Ala polymorphism in the peroxisome proliferator-activated receptor gamma (PPAR $\gamma$ ) gene affecting BMI and insulin sensitivity has been observed in several studies.95-97

These gene-environment interactions might explain the heterogeneity in studies associating dietary factors and obesity, and may also contribute to the lack of replication of genetic associations. Despite the identification of many obesity genes, ${ }^{98}$ relatively few studies have been conducted investigating the effects of geneenvironment interactions on obesity development, which is a very important issue for better targeting the obesity prevention and programs.

\section{Physiological Regulation of Food Intake}

Physiological regulation of food intake can be divided into two phases: satiation and satiety. Satiation develops during a meal, ends eating, and determines the meal sizes. Satiety develops after foods have been ingested, delays the onset of the next meal and controls the inter-meal intervals. The regulation of satiation and satiety, thereby energy intake, is conducted by the hypothalamic signaling network. ${ }^{99}$ This network involves three main sets of signals.

The first set comprises of gut hormones such as cholecystokinin (CCK), glucagon-like peptide-1 (GLP-1) and ghrelin. CCK and GLP-1 are released from the gut following food consumption to terminate meals (satiation) and their effects depend on gastric distention. ${ }^{100}$ Therefore, inhibiting the gastric emptying rate could lead to a higher satiation which might be the underlying mechanism for the satiating effects of diets high in fiber and low in glycemic index.7, 101 Ghrelin is the only gut hormone stimulating meal initiation (reducing satiety). In addition, metabolites in blood after absorption could influence people's feeling of fullness (satiety). For example, the transient and dynamic declines in blood glucose concentrations could also promote eating (glucostatic hypothesis). ${ }^{100}$ This may also explain the low satiating effects of high GI foods because, as compared to low GI foods, high GI 
foods cause high blood glucose levels immediately after consumption, followed by a low level of blood glucose and free fatty acids at middle postprandial stage. This low-fuel state could stimulate meal initiation.101, 102 It has been noted that macronutrients exert hierarchical effects on satiety in the order of protein > carbohydrate $>$ fat. In addition, many short-term intake studies show that the weight or volume, rather than the energy content, of foods is one of the most important determinants of meal size. ${ }^{100}$ Energy dense foods are usually high in fat and low in water and fiber, and are consequently less satiating. ${ }^{103}$

Adiposity signals, including leptin and insulin, are the second set of signals. They monitor the nutritional status of the body, mediate the effects of gut hormones on the hypothalamus, and influence the sensitivity of the hypothalamus to satiety hormones such as CCK. For example, leptin deficiency induced by fasting limits the satiating effect of CCK, which, in turn, leads to an increased food intake during a meal, thereby restoring energy balance. 104

Signals released by the central nerve system, especially the hypothalamus, are the third set of signals and include alpa-melanocyte-stimulating hormone ( $\alpha-\mathrm{MSH})$ and its precursor pro-opiomelanocortin (POMC) (inhibits food intake) and neuropeptide Y (NPY) (increases food intake). ${ }^{99}$ A simplistic overview of the physiological regulation of energy intake is depicted in Figure 1-1.

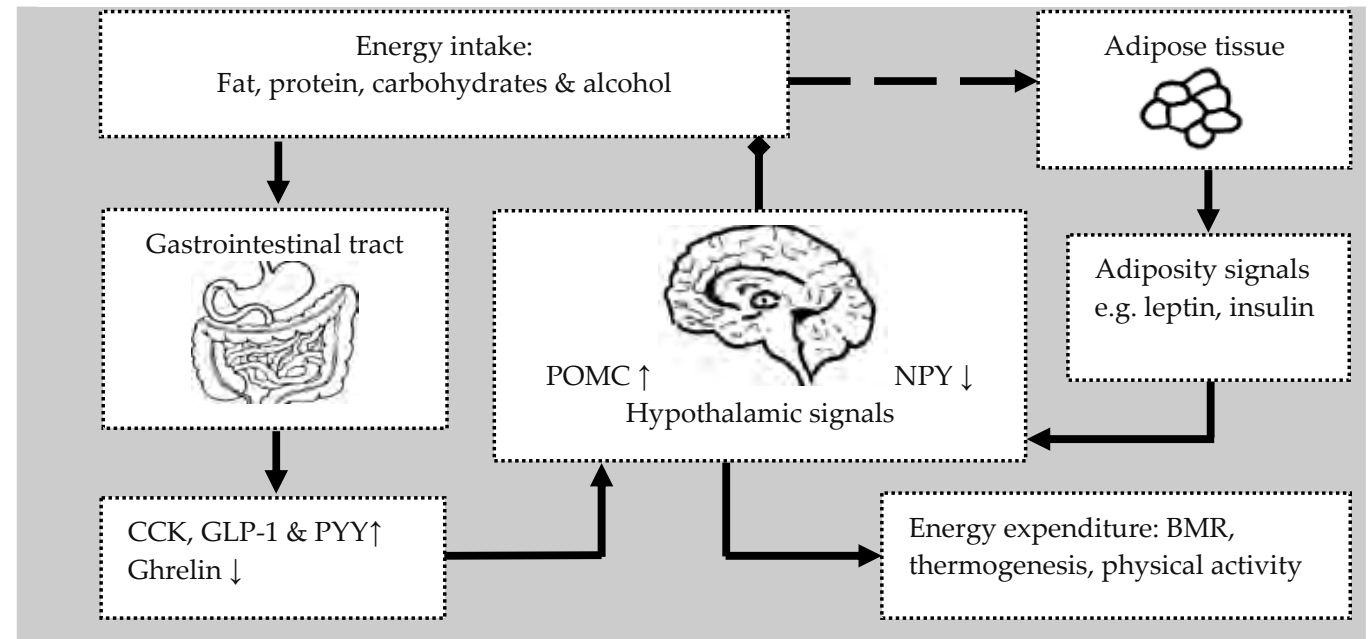

Figure 1-1. Schematic overview of energy intake regulation.

\section{Rational and Outline of the Thesis}

Obesity is a preventable condition and the prevention is easier, less expensive and more effective as compared to the treatment. However, there is little data available on the impacts of dietary factors in the prevention of weight or adiposity gain. On the other hand, quite a large number of studies have been conducted 
investigating the effects of dietary factors in treating obesity and any low calorie diet seems to work. ${ }^{105}$ But, dietary factors which could induce a quick weight loss among obese subjects may not be appropriate for a long-term use in order to prevent weight gain, such as the well-known very-low-carbohydrate diet.106-108 In addition, they may not equally effective in obesity prevention. For example, in the Women's Health Initiative, one of the longer-term intervention studies on weight loss, the low-fat group initially lost weight but then gained weight at least as fast as the control group. 109

Investigating the effects of dietary factors on the prevention of subsequent weight gain in the general population is of important public health relevance. The DiOGenes project was set up with the primary goal as to determine the efficacy of dietary macronutrient components for the prevention of weight gain and regain, due to the difficulties of conducting large intervention studies on primary weight gain. ${ }^{110}$ Within the research line of the DiOGenes population-based cohort study, this thesis was initiated to investigate the associations of dietary factors having impacts on satiation or satiety, including dietary GI, GL, ED, and fiber intake, and the genetic variants involved in energy intake regulation with subsequent weight and waist circumference change. For this purpose, we analyzed data of 89,432 participants from five European countries that are involved in the existing EPIC study (European Prospective Investigation into Cancer and Nutrition). First, to better understand the GI concept, a narrative review about the physiological mechanisms underlying the potential associations between GI and chronic diseases including diabetes, cardiovascular diseases, obesity and certain cancers was conducted and this part of work is presented in Chapter 2. Given that the food frequency questionnaires (FFQs) used in this study are not specially designed to assess GI and GL and the validities of the measurements were unknown, two studies were conducted to obtain insights into the relative validities of GI and GL measured by the FFQ used in the Dutch part of the EPIC study. Chapter 3 describes the cross-sectional associations between GI, GL and food intake as well as metabolic risk factors including blood glucose, insulin, lipids and the inflammatory marker C-reactive protein. In Chapter 4, the reproducibility and relative validity of GI and GL, as compared to the measurements from multiple 24-hour recalls, is described. Chapter 5, 6 and 7 present the associations of GI and GL, dietary energy density, and the intake of fiber (in total and from different food sources) with subsequent changes of weight and waist circumference respectively. Given the critical role of the hypothalamic signaling network in regulating energy intake hence body weight, the effects of SNPs in or near genes involved in this network have been investigated. The interactions of these SNPs with dietary GI were also investigated (Chapter 8). This thesis ends with Chapter 9, in which the research findings are discussed in a broader context and implications for future research and developments are explored. 


\section{References}

1. WHO. Global Strategy on Diet, Physical Activity and Health-Obesity and Overweight Geneva 2003.

2. Janssen I, Heymsfield SB, Allison DB, et al. Body mass index and waist circumference independently contribute to the prediction of nonabdominal, abdominal subcutaneous, and visceral fat. Am J Clin Nutr. 2002;75(4):683-688.

3. Swinburn BA, Sacks G, Lo SK, et al. Estimating the changes in energy flux that characterize the rise in obesity prevalence. Am J Clin Nutr. 2009;89(6):1723-1728.

4. Jebb SA. Dietary determinants of obesity. Obes Rev. 2007;8 Suppl 1:93-97.

5. Swinburn BA, Caterson I, Seidell JC, et al. Diet, nutrition and the prevention of excess weight gain and obesity. Public Health Nutr. 2004;7(1A):123-146.

6. WHO/FAO. Diet, nutrition and the prevention of chronic diseases: report of a joint WHO/FAO expert consultation. Geneva 2003.

7. Pereira MA, Ludwig DS. Dietary fiber and body-weight regulation. Observations and mechanisms. Pediatr Clin North Am. 2001;48(4):969-980.

8. Birketvedt GS, Aaseth J, Florholmen JR, et al. Long-term effect of fibre supplement and reduced energy intake on body weight and blood lipids in overweight subjects. Acta Medica (Hradec Kralove). 2000;43(4):129-132.

9. Liu S, Willett WC, Manson JE, et al. Relation between changes in intakes of dietary fiber and grain products and changes in weight and development of obesity among middle-aged women. Am J Clin Nutr. 2003;78(5):920-927.

10. Ludwig DS, Pereira MA, Kroenke $\mathrm{CH}$, et al. Dietary fiber, weight gain, and cardiovascular disease risk factors in young adults. Jama. 1999;282(16):1539-1546.

11. Ledikwe JH, Blanck HM, Kettel Khan L, et al. Dietary energy density is associated with energy intake and weight status in US adults. Am J Clin Nutr. 2006;83(6):1362-1368.

12. Prentice AM, Poppitt SD. Importance of energy density and macronutrients in the regulation of energy intake. Int J Obes Relat Metab Disord. 1996;20 Suppl 2:S18-23.

13. McCrory MA, Saltzman E, Rolls BJ, et al. A twin study of the effects of energy density and palatability on energy intake of individual foods. Physiol Behav. 2006;87(3):451-459.

14. Ello-Martin JA, Roe LS, Ledikwe JH, et al. Dietary energy density in the treatment of obesity: a yearlong trial comparing 2 weight-loss diets. Am J Clin Nutr. 2007;85(6):1465-1477.

15. Ledikwe JH, Rolls BJ, Smiciklas-Wright $\mathrm{H}$, et al. Reductions in dietary energy density are associated with weight loss in overweight and obese participants in the PREMIER trial. Am J Clin Nutr. 2007;85(5):1212-1221.

16. Rolls BJ, Roe LS, Beach AM, et al. Provision of foods differing in energy density affects long-term weight loss. Obes Res. 2005;13(6):1052-1060.

17. Panagiotakos DB, Papadimitriou A, Anthracopoulos MB, et al. Birthweight, breast-feeding, parental weight and prevalence of obesity in schoolchildren aged 10-12 years, in Greece; the Physical Activity, Nutrition and Allergies in Children Examined in Athens (PANACEA) study. Pediatr Int. 2008;50(4):563-568.

18. Kvaavik E, Tell GS, Klepp KI. Surveys of Norwegian youth indicated that breast feeding reduced subsequent risk of obesity. J Clin Epidemiol. 2005;58(8):849-855.

19. Arenz S, Ruckerl R, Koletzko B, et al. Breast-feeding and childhood obesity--a systematic review. Int J Obes Relat Metab Disord. 2004;28(10):1247-1256.

20. von Kries R, Koletzko B, Sauerwald T, et al. Breast feeding and obesity: cross sectional study. BMJ. 1999;319(7203):147-150.

21. Mennella JA. Flavour programming during breast-feeding. Adv Exp Med Biol. 2009;639:113-120.

22. Dietz WH. Breastfeeding may help prevent childhood overweight. JAMA. 2001;285(19):2506-2507.

23. Kramer MS, Matush L, Vanilovich I, et al. Effects of prolonged and exclusive breastfeeding on child height, weight, adiposity, and blood pressure at age $6.5 \mathrm{y}$ : evidence from a large randomized trial. Am J Clin Nutr. 2007;86(6):1717-1721.

24. Kramer MS, Matush L, Vanilovich I, et al. A randomized breast-feeding promotion intervention did not reduce child obesity in Belarus. The Journal of nutrition. 2009;139(2):417S-421S. 
25. Mattes RD. Dietary compensation by humans for supplemental energy provided as ethanol or carbohydrate in fluids. Physiol Behav. 1996;59(1):179-187.

26. Schwarz JM, Linfoot P, Dare D, et al. Hepatic de novo lipogenesis in normoinsulinemic and hyperinsulinemic subjects consuming high-fat, low-carbohydrate and low-fat, high-carbohydrate isoenergetic diets. Am J Clin Nutr. 2003;77(1):43-50.

27. Hill JO, Prentice AM. Sugar and body weight regulation. Am J Clin Nutr. 1995;62(1 Suppl):264S-273S; discussion 273S-274S.

28. Gill TP, Rangan AM, Webb KL. The weight of evidence suggests that soft drinks are a major issue in childhood and adolescent obesity. Med J Aust. 2006;184(6):263-264.

29. Gibson S. Sugar-sweetened soft drinks and obesity: a systematic review of the evidence from observational studies and interventions. Nutr Res Rev. 2008;21(2):134-147.

30. Jenkins DJ, Wolever TM, Taylor RH, et al. Glycemic index of foods: a physiological basis for carbohydrate exchange. Am J Clin Nutr. 1981;34(3):362-366.

31. Salmeron J, Manson JE, Stampfer MJ, et al. Dietary fiber, glycemic load, and risk of non-insulindependent diabetes mellitus in women. Jama. 1997;277(6):472-477.

32. Ludwig DS. Dietary glycemic index and the regulation of body weight. Lipids. 2003;38(2):117-121.

33. Ball SD, Keller KR, Moyer-Mileur LJ, et al. Prolongation of satiety after low versus moderately high glycemic index meals in obese adolescents. Pediatrics. 2003;111(3):488-494.

34. Stevenson EJ, Williams C, Mash LE, et al. Influence of high-carbohydrate mixed meals with different glycemic indexes on substrate utilization during subsequent exercise in women. Am J Clin Nutr. 2006;84(2):354-360.

35. Pereira MA, Swain J, Goldfine AB, et al. Effects of a low-glycemic load diet on resting energy expenditure and heart disease risk factors during weight loss. Jama. 2004;292(20):2482-2490.

36. Du H, van der A DL, Feskens EJ. Dietary glycaemic index: a review of the physiological mechanisms and observed health impacts. Acta Cardiol. 2006;61(4):383-397.

37. Thomas DE, Elliott E, Baur L. Low glycaemic index or low glycaemic load diets for overweight and obesity. Cochrane Database Syst Rev. 2007(3):CD005105.

38. Aston LM, Stokes CS, Jebb SA. No effect of a diet with a reduced glycaemic index on satiety, energy intake and body weight in overweight and obese women. Int J Obes (Lond). 2008;32(1):160-165.

39. Das SK, Gilhooly CH, Golden JK, et al. Long-term effects of 2 energy-restricted diets differing in glycemic load on dietary adherence, body composition, and metabolism in CALERIE: a 1-y randomized controlled trial. Am J Clin Nutr. 2007;85(4):1023-1030.

40. Sichieri R, Moura AS, Genelhu V, et al. An 18-mo randomized trial of a low-glycemic-index diet and weight change in Brazilian women. Am J Clin Nutr. 2007;86(3):707-713.

41. de Rougemont A, Normand S, Nazare JA, et al. Beneficial effects of a 5-week low-glycaemic index regimen on weight control and cardiovascular risk factors in overweight non-diabetic subjects. $\mathrm{Br} J$ Nutr. 2007:1-11.

42. Ma Y, Olendzki B, Chiriboga D, et al. Association between dietary carbohydrates and body weight. Am J Epidemiol. 2005;161(4):359-367.

43. Hare-Bruun H, Flint A, Heitmann BL. Glycemic index and glycemic load in relation to changes in body weight, body fat distribution, and body composition in adult Danes. Am J Clin Nutr. 2006;84(4):871-879; quiz 952-873.

44. St Jeor ST, Howard BV, Prewitt TE, et al. Dietary protein and weight reduction: a statement for healthcare professionals from the Nutrition Committee of the Council on Nutrition, Physical Activity, and Metabolism of the American Heart Association. Circulation. 2001;104(15):1869-1874.

45. Mikkelsen PB, Toubro S, Astrup A. Effect of fat-reduced diets on 24-h energy expenditure: comparisons between animal protein, vegetable protein, and carbohydrate. Am J Clin Nutr. 2000;72(5):1135-1141.

46. Norris J, Harnack L, Carmichael S, et al. US trends in nutrient intake: the 1987 and 1992 National Health Interview Surveys. Am J Public Health. 1997;87(5):740-746.

47. Cavadini C, Siega-Riz AM, Popkin BM. US adolescent food intake trends from 1965 to 1996. Arch Dis Child. 2000;83(1):18-24. 
48. Lluch A, Herbeth B, Mejean L, et al. Dietary intakes, eating style and overweight in the Stanislas Family Study. Int J Obes Relat Metab Disord. 2000;24(11):1493-1499.

49. Trichopoulou A, Gnardellis C, Benetou V, et al. Lipid, protein and carbohydrate intake in relation to body mass index. Eur J Clin Nutr. 2002;56(1):37-43.

50. Gunther AL, Remer T, Kroke A, et al. Early protein intake and later obesity risk: which protein sources at which time points throughout infancy and childhood are important for body mass index and body fat percentage at $7 \mathrm{y}$ of age? Am J Clin Nutr. 2007;86(6):1765-1772.

51. Simpson SJ, Raubenheimer D. Obesity: the protein leverage hypothesis. Obes Rev. 2005;6(2):133-142.

52. Merchant AT, Anand SS, Vuksan V, et al. Protein intake is inversely associated with abdominal obesity in a multi-ethnic population. The Journal of nutrition. 2005;135(5):1196-1201.

53. Lejeune MP, Kovacs EM, Westerterp-Plantenga MS. Additional protein intake limits weight regain after weight loss in humans. Br J Nutr. 2005;93(2):281-289.

54. Berg C, Lappas G, Wolk A, et al. Eating patterns and portion size associated with obesity in a Swedish population. Appetite. 2009;52(1):21-26.

55. Kelly MT, Wallace JM, Robson PJ, et al. Increased portion size leads to a sustained increase in energy intake over $4 \mathrm{~d}$ in normal-weight and overweight men and women. Br J Nutr. 2009;102(3):470-477.

56. Rolls BJ. The Supersizing of America: Portion Size and the Obesity Epidemic. Nutr Today. 2003;38(2):42-53.

57. Diliberti N, Bordi PL, Conklin MT, et al. Increased portion size leads to increased energy intake in a restaurant meal. Obes Res. 2004;12(3):562-568.

58. Rolls BJ, Engell D, Birch LL. Serving portion size influences 5-year-old but not 3-year-old children's food intakes. J Am Diet Assoc. 2000;100(2):232-234.

59. Zoumas-Morse C, Rock CL, Sobo EJ, et al. Children's patterns of macronutrient intake and associations with restaurant and home eating. J Am Diet Assoc. 2001;101(8):923-925.

60. Bowman SA, Vinyard BT. Fast food consumption of U.S. adults: impact on energy and nutrient intakes and overweight status. J Am Coll Nutr. 2004;23(2):163-168.

61. McCrory MA, Fuss PJ, Saltzman E, et al. Dietary determinants of energy intake and weight regulation in healthy adults. The Journal of nutrition. 2000;130(2S Suppl):276S-279S.

62. Chaput JP, Leblanc C, Perusse L, et al. Risk Factors for Adult Overweight and Obesity in the Quebec Family Study: Have We Been Barking Up the Wrong Tree? Obesity (Silver Spring). 2009;17(10):19641970.

63. Hays NP, Roberts SB. Aspects of eating behaviors "disinhibition" and "restraint" are related to weight gain and BMI in women. Obesity (Silver Spring). 2008;16(1):52-58.

64. Provencher V, Drapeau V, Tremblay A, et al. Eating behaviors and indexes of body composition in men and women from the Quebec family study. Obes Res. 2003;11(6):783-792.

65. Jenkins DJ, Wolever TM, Vuksan V, et al. Nibbling versus gorging: metabolic advantages of increased meal frequency. N Engl J Med. 1989;321(14):929-934.

66. Toschke AM, Kuchenhoff H, Koletzko B, et al. Meal frequency and childhood obesity. Obes Res. 2005;13(11):1932-1938.

67. Berteus Forslund H, Lindroos AK, Sjostrom L, et al. Meal patterns and obesity in Swedish women-a simple instrument describing usual meal types, frequency and temporal distribution. Eur J Clin Nutr. 2002;56(8):740-747.

68. Croezen S, Visscher TL, Ter Bogt NC, et al. Skipping breakfast, alcohol consumption and physical inactivity as risk factors for overweight and obesity in adolescents: results of the E-MOVO project. Eur J Clin Nutr. 2009;63(3):405-412.

69. Kruger J, Ham SA, Prohaska TR. Behavioral risk factors associated with overweight and obesity among older adults: the 2005 National Health Interview Survey. Prev Chronic Dis. 2009;6(1):A14.

70. Schroder H, Morales-Molina JA, Bermejo S, et al. Relationship of abdominal obesity with alcohol consumption at population scale. Eur J Nutr. 2007;46(7):369-376.

71. Good CK, Holschuh N, Albertson AM, et al. Whole grain consumption and body mass index in adult women: an analysis of NHANES 1999-2000 and the USDA pyramid servings database. J Am Coll Nutr. 2008;27(1):80-87. 
72. Vioque J, Weinbrenner T, Castello A, et al. Intake of fruits and vegetables in relation to 10-year weight gain among Spanish adults. Obesity (Silver Spring). 2008;16(3):664-670.

73. Hill JO, Melanson EL, Wyatt HT. Dietary fat intake and regulation of energy balance: implications for obesity. The Journal of nutrition. 2000;130(2S Suppl):284S-288S.

74. Newby PK, Muller D, Hallfrisch J, et al. Dietary patterns and changes in body mass index and waist circumference in adults. Am J Clin Nutr. 2003;77(6):1417-1425.

75. Littman AJ, Kristal AR, White E. Effects of physical activity intensity, frequency, and activity type on 10-y weight change in middle-aged men and women. Int J Obes (Lond). 2005;29(5):524-533.

76. Besson H, Ekelund U, Luan J, et al. A cross-sectional analysis of physical activity and obesity indicators in European participants of the EPIC-PANACEA study. Int J Obes (Lond). 2009;33(4):497506.

77. Hill JO, Wyatt HR. Role of physical activity in preventing and treating obesity. J Appl Physiol. 2005;99(2):765-770.

78. Oken E, Gillman MW. Fetal origins of obesity. Obes Res. 2003;11(4):496-506.

79. Eriksson JG, Forsen T, Tuomilehto J, et al. Catch-up growth in childhood and death from coronary heart disease: longitudinal study. Bmj. 1999;318(7181):427-431.

80. Ravelli GP, Stein ZA, Susser MW. Obesity in young men after famine exposure in utero and early infancy. N Engl J Med. 1976;295(7):349-353.

81. Ravelli AC, van Der Meulen JH, Osmond C, et al. Obesity at the age of 50 y in men and women exposed to famine prenatally. Am J Clin Nutr. 1999;70(5):811-816.

82. Cottrell EC, Ozanne SE. Early life programming of obesity and metabolic disease. Physiol Behav. 2008;94(1):17-28.

83. Patel SR, Hu FB. Short sleep duration and weight gain: a systematic review. Obesity (Silver Spring). 2008;16(3):643-653.

84. van den Berg JF, Knvistingh Neven A, Tulen JH, et al. Actigraphic sleep duration and fragmentation are related to obesity in the elderly: the Rotterdam Study. Int J Obes (Lond). 2008;32(7):1083-1090.

85. Spiegel K, Tasali E, Penev P, et al. Brief communication: Sleep curtailment in healthy young men is associated with decreased leptin levels, elevated ghrelin levels, and increased hunger and appetite. Ann Intern Med. 2004;141(11):846-850.

86. Tasali E, Leproult R, Ehrmann DA, et al. Slow-wave sleep and the risk of type 2 diabetes in humans. Proc Natl Acad Sci U S A. 2008;105(3):1044-1049.

87. Cannon B, Nedergaard J. Brown adipose tissue: function and physiological significance. Physiol Rev. 2004;84(1):277-359.

88. Cypess AM, Lehman S, Williams G, et al. Identification and importance of brown adipose tissue in adult humans. N Engl J Med. 2009;360(15):1509-1517.

89. van Marken Lichtenbelt WD, Vanhommerig JW, Smulders NM, et al. Cold-activated brown adipose tissue in healthy men. N Engl J Med. 2009;360(15):1500-1508.

90. Farmer SR. Obesity: Be cool, lose weight. Nature. 2009;458(7240):839-840.

91. Perusse L, Bouchard C. Gene-diet interactions in obesity. Am J Clin Nutr. 2000;72(5 Suppl):1285S1290 S.

92. Tataranni PA. Obesity in the Pimas. Rev Endocr Metab Disord. 2001;2(4):365-369.

93. Song Y, Miyaki K, Araki J, et al. The interaction between the interleukin 6 receptor gene genotype and dietary energy intake on abdominal obesity in Japanese men. Metabolism. 2007;56(7):925-930.

94. Andreasen $\mathrm{CH}$, Stender-Petersen $\mathrm{KL}$, Mogensen MS, et al. Low physical activity accentuates the effect of the FTO rs9939609 polymorphism on body fat accumulation. Diabetes. 2008;57(1):95-101.

95. Memisoglu A, Hu FB, Hankinson SE, et al. Interaction between a peroxisome proliferator-activated receptor gamma gene polymorphism and dietary fat intake in relation to body mass. Hum Mol Genet. 2003;12(22):2923-2929.

96. Luan J, Browne PO, Harding AH, et al. Evidence for gene-nutrient interaction at the PPARgamma locus. Diabetes. 2001;50(3):686-689. 
97. Robitaille J, Despres JP, Perusse L, et al. The PPAR-gamma P12A polymorphism modulates the relationship between dietary fat intake and components of the metabolic syndrome: results from the Quebec Family Study. Clin Genet. 2003;63(2):109-116.

98. Rankinen T, Zuberi A, Chagnon YC, et al. The human obesity gene map: the 2005 update. Obesity (Silver Spring, $M d$. 2006;14(4):529-644.

99. Woods SC, Seeley RJ, Cota D. Regulation of food intake through hypothalamic signaling networks involving mTOR. Annual review of nutrition. 2008;28:295-311.

100. de Graaf C, Blom WA, Smeets PA, et al. Biomarkers of satiation and satiety. Am J Clin Nutr. 2004;79(6):946-961.

101. Bornet FR, Jardy-Gennetier AE, Jacquet N, et al. Glycaemic response to foods: impact on satiety and long-term weight regulation. Appetite. 2007;49(3):535-553.

102. Brand-Miller JC, Holt SH, Pawlak DB, et al. Glycemic index and obesity. Am J Clin Nutr. 2002;76(1):281S-285S.

103. Rolls BJ. The relationship between dietary energy density and energy intake. Physiol Behav. 2009;97(5):609-615.

104. McMinn JE, Sindelar DK, Havel PJ, et al. Leptin deficiency induced by fasting impairs the satiety response to cholecystokinin. Endocrinology. 2000;141(12):4442-4448.

105. Sacks FM, Bray GA, Carey VJ, et al. Comparison of weight-loss diets with different compositions of fat, protein, and carbohydrates. N Engl J Med. 2009;360(9):859-873.

106. Astrup A, Meinert Larsen T, Harper A. Atkins and other low-carbohydrate diets: hoax or an effective tool for weight loss? Lancet. 2004;364(9437):897-899.

107. Brinkworth GD, Noakes M, Buckley JD, et al. Long-term effects of a very-low-carbohydrate weight loss diet compared with an isocaloric low-fat diet after 12 mo. Am J Clin Nutr. 2009;90(1):23-32.

108. Tay J, Brinkworth GD, Noakes M, et al. Metabolic effects of weight loss on a very-low-carbohydrate diet compared with an isocaloric high-carbohydrate diet in abdominally obese subjects. J Am Coll Cardiol. 2008;51(1):59-67.

109. Howard BV, Manson JE, Stefanick ML, et al. Low-fat dietary pattern and weight change over 7 years: the Women's Health Initiative Dietary Modification Trial. Jama. 2006;295(1):39-49.

110. Saris WH, Harper A. DiOGenes: a multidisciplinary offensive focused on the obesity epidemic. Obes Rev. 2005;6(2):175-176. 



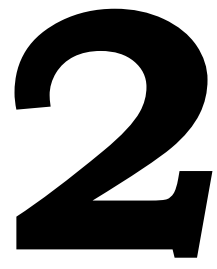

\title{
Dietary glycemic index: a review of the physiological mechanisms and observed health impacts
}

\author{
H. Du, D.L. van der A, E. J.M. Feskens.
}

Acta Cardiol. 2006;61(4):383-397

\section{Introduction}

Carbohydrates (CHOs) are the most important energy source in human diets and are often classified by their molecular size as sugar, oligosaccharides, polysaccharides, and polyols (hydrogenated CHOs). ${ }^{1}$ However, the relevance of this structural classification has been questioned and interest in an alternative property of CHOs has grown. ${ }^{2}$ The glycemic index (GI) is a contribution of Jenkins and coworkers in 1981 to classify $\mathrm{CHO}$ containing foods according to their impacts on body's postprandial glycemic response. ${ }^{3}$ GI is defined as "The incremental area under the 2-hour blood glucose response curve of a test food containing $50 \mathrm{~g}$ of glycemic (available) CHOs expressed as the percentage of the response to the same amount of glycemic CHOs from a standard food (either white bread or glucose) taken by the same subject". ${ }^{4}$ Although white bread and glucose both give valid values, glucose may be the preferred control because of its stable composition. When, for any reason, white bread is used as reference, the obtained GI value needs to be divided by 1.4 to get the GI value contrast to glucose.

Over the past decades, the concept of GI has attracted attention from various sectors such as the general public, commercial sectors, and health care professionals. The Food and Agriculture Organization (FAO) and World Health Organization (WHO) Joint Expert Consultation report has recommended the use of GI for categorizing dietary $\mathrm{CHOs}$ and to guide people's food choices. ${ }^{4}$ But in addition to the appraisal, criticism on the utility and validity of GI is also present in scientific journals. This review will cover the physiological mechanisms of GI as well as the evidence gathered thus far about the health impacts of low GI diets on morbidity and mortality from chronic diseases such as diabetes, obesity, cardiovascular disease and cancer.

\section{Methods}

A PubMed (MEDLINE) search using the search strategy "glycemic index OR glycaemic index" located a total of 675 English publications (till mid December, 2005). Among them, articles related to physiological mechanisms and effects on the risk 
and treatment of diabetes, obesity, cardiovascular disease and cancer were carefully studied. In addition, reference lists of these articles were hand searched for other relevant publications and current healthy eating guidelines from different nations were gone through.

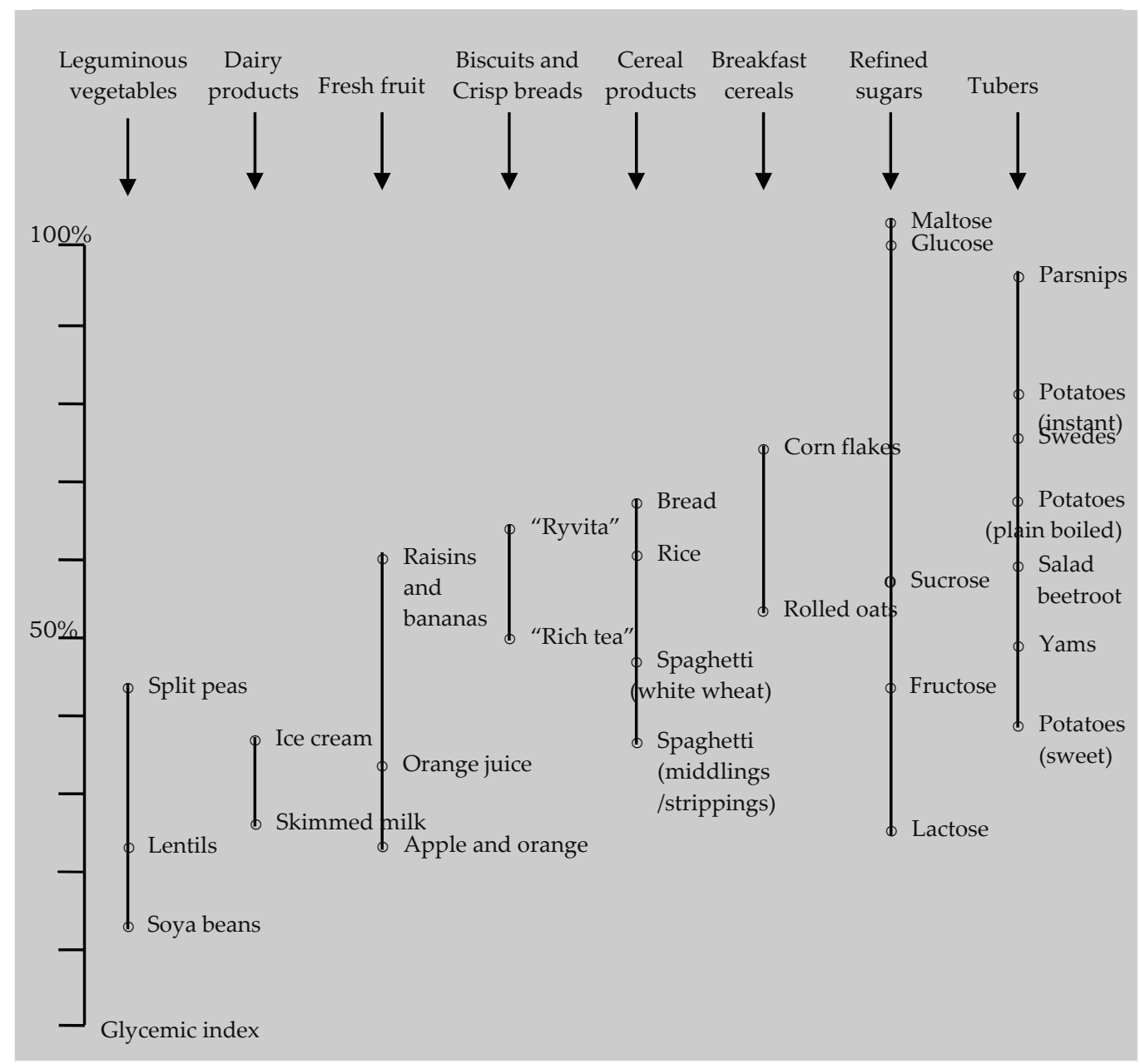

Figure 2-1. Glycemic indices of several foods and food categories (adapted from Bornet ${ }^{5}$ ).

\section{Results}

\section{Carbohydrate physiology and glycemic index}

The digestion, absorption and metabolism of $\mathrm{CHOs}$ are complex processes in which disaccharides and polysaccharides need to be broken down to monosaccharides prior to absorption. Digestion of CHOs starts in mouth although its predominant site is the small intestine where maltose (from starch) is broken down into two molecules of glucose; lactose into one glucose and one galactose and sucrose 
into one glucose and one fructose by enzyme maltase, lactase and sucrase, respectively. Subsequently, these monosaccharides are transported across the intestinal wall to the hepatic portal vein and then to liver parenchymal cells and other tissues via distinct mechanisms. For example glucose and galactose are taken into the enterocytes by secondary active transport, whereas fructose is absorbed into the cells passively down a concentration gradient. ${ }^{4}$ Furthermore, the metabolic fates of these three monosaccharides are quite different as well: glucose can be catabolized to produce ATP, stored as glycogen when energy supply is sufficient or converted into fatty acids once muscle and liver glycogen stores are saturated. As for fructose and galactose, they are not direct energy source and need to be converted to glucose in the liver before they can supply ATP. All of the above mentioned aspects account for the fact that sucrose, lactose and fructose have lower GI values than glucose (Figure 2-1).

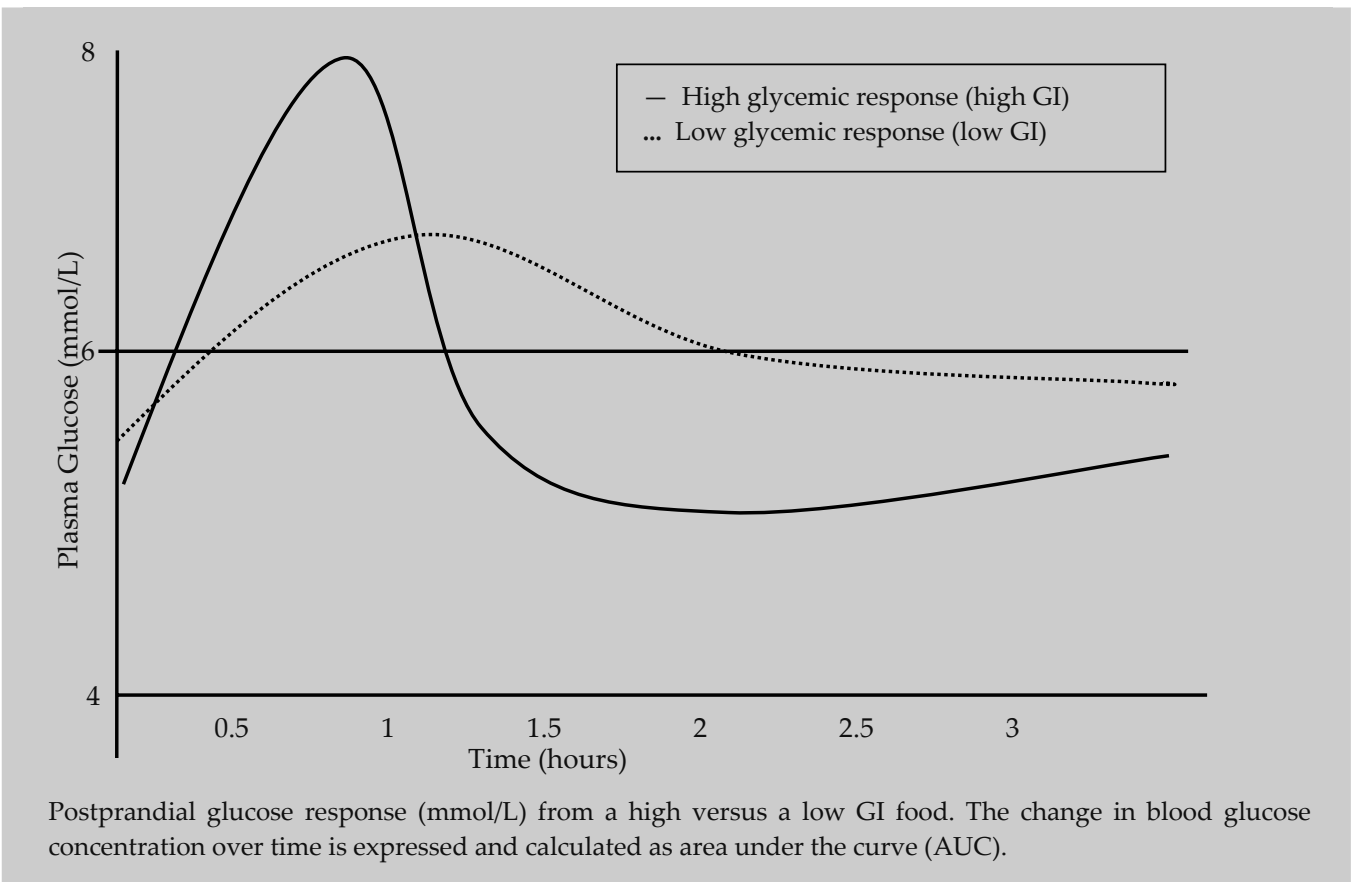

Figure 2-2. Postprandial blood glucose responses from foods with different GI values ( www.glycemicindex.com).

As shown in Figure 2-1, CHO containing foods, even though they belong to the same food category, cover a wide range of GI values. Generally, they are arbitrarily categorized as low, medium or high GI foods if their GI values are $\leq 55,55<\mathrm{GI}<70$, or $\geq 70$ (vs. glucose $=100$ ), respectively. Low GI foods have slow digestion and absorption rates, and hence cause a small and gradual rise in postprandial blood glucose levels. In contrast, high GI foods are characterized by fast $\mathrm{CHO}$ digestion 
and absorption, and hence cause a large and rapid increase in postprandial blood glucose (Figure 2-2). Some researchers believe that this response is independent of the amount of $\mathrm{CHOs}^{6,7}$ whereas others claim that it is the quantity of $\mathrm{CHOs}$ that is more important. ${ }^{8}$ To eliminate concerns about the influence of $\mathrm{CHO}$ quantity on postprandial glucose response, researchers at Harvard University developed the concept of glycemic load (GL) in 1990s. ${ }^{9}$ It combines both the quality (GI) and quantity of CHOs in a food or meal and is defined by a food or meal's GI (in percentage) multiplied by its available $\mathrm{CHO}$ content in grams $(\mathrm{GL}=\mathrm{GI} / 100 \times$ the amount of available $\mathrm{CHOs}$ ). Foods with similar GI values may have completely different GL levels, and vice versa. For example, carrots and basmati rice may have similar GI values, but one serving of rice has a much higher GL than one serving of carrots due to the larger $\mathrm{CHO}$ content of rice. ${ }^{10}$ Changing the GL of meals can be achieved by adjusting either the overall GI or total CHO intake. However, replacing high GI foods by low GI equivalents (thereby reducing the diets' overall GI level) is more meaningful and applicable than cutting down $\mathrm{CHO}$ consumption (the other approach to reduce overall GL). This is because CHOs are important components of a balanced diet and very low $\mathrm{CHO}$ diets are unavoidably high in fat which in turn will increase the risk of cardiovascular disease. Besides, $\mathrm{CHO}$ containing foods are important sources of many nutrients, such as vitamins, minerals and fiber. Given the above, low $\mathrm{CHO}$ diets are not recommended ${ }^{11}$ (according to the USDA, CHOs should provide $55 \%$ of total energy intake ${ }^{12}$ ) and high $\mathrm{CHO}$ low GI diets should be advocated.

The physiological responses after the ingestion of a high GI food compared with a low GI food are clearly explained by Ludwig. ${ }^{2}$ In summary, high GI food consumption is often followed by a rapid increase in blood glucose, which will stimulate the beta-cells of the pancreas to increase insulin secretion to a larger extent. Fat oxidation is inhibited by this hyperglycemic status and blood free fatty acid level is low. At the middle postprandial stage, the marked rise in blood insulin level leads to a rapid downward regulation of blood glucose (often to below fasting level). Fat oxidation remains suppressed and blood free fatty acid concentration maintains a low level. At the late postprandial stage, hypoglycemia stimulates the release of counter-regulatory hormones to restore euglycemia and the activation of fat oxidation to meet body's energy needs. A marked increase in free fatty acid concentration thus follows. In contrast, a low GI food consumption results in lower but more sustained increases in blood glucose, thus less demand on pancreatic betacells and mild changes in blood free fatty acid levels.

Despite the popular success of the GI, also in the lay press, there is still no agreement reached on the utility of the GI concept in clinical as well as public health settings. Generally speaking, criticism on the GI can be summarized as follows:

Firstly, many intrinsic and extrinsic factors affecting food digestibility, gastrointestinal motility or insulin secretion have impacts on the GI value of a specific food. ${ }^{13-15}$ These not only include the nature of the CHOs, but also other 
factors such as the physical form of a food, its ripeness, the methods of cooking and processing, etc. (Table 2-1)., ${ }^{116-18}$ This is why different varieties of the same food may differ widely in their GI values. For instance, eight potato varieties that are commercially available on the UK market have GI values ranging from 56 to $94 .{ }^{19}$ Some researchers are even claiming that the glycemic response to a mixed meal cannot be predicted from the published GI values of the composite foods. ${ }^{20-22}$ Under these circumstances, GI has been criticized as not being applicable and useless in daily life. However, there is also evidence on the usefulness of the GI in the context of mixed meals. ${ }^{23,24}$ Although additional fat, protein or other components in a meal might influence the glycemic response, the rank order of the glycemic response to different $\mathrm{CHO}$ containing meals can still be predicted with reasonable accuracy from the GI values of constituent foods if standard procedures are followed.2, 25

\section{Table 2-1. Factors which have an influence on the glycemic index (GI) of foods.}

\begin{tabular}{|c|c|c|}
\hline \multicolumn{2}{|c|}{ Factors } & Impacts \\
\hline \multirow{4}{*}{$\mathrm{CHO}$ structure } & $\begin{array}{l}\text { Monosaccharide } \\
\text { components }\end{array}$ & $\begin{array}{l}\text { Glucose has a higher GI value than fructose and galactose. So, the } \\
\text { higher the relative content of glucose, the higher the GI value. }\end{array}$ \\
\hline & $\begin{array}{l}\text { Amylose vs. } \\
\text { amylopectin }\end{array}$ & $\begin{array}{l}\text { Starch rich in amylose has a more compact structure and is more } \\
\text { resistant to absorption and digestion than starch rich in } \\
\text { amylopectin. So the higher the relative content of amylose vs. } \\
\text { amylopectin, the lower the GI. }\end{array}$ \\
\hline & $\begin{array}{l}\text { Particle size and } \\
\text { physical barriers }\end{array}$ & $\begin{array}{l}\text { Foods that are smaller in particle size and lack physical barriers } \\
\text { (e.g. seed coats) are more easily digested and are inclined to have } \\
\text { higher GI values. For example, refined and highly processed } \\
\text { foods normally have higher GI values than whole grains and } \\
\text { legumes. }\end{array}$ \\
\hline & $\begin{array}{l}\text { Starch } \\
\text { gelatinization }\end{array}$ & $\begin{array}{l}\text { The more gelatinization, the more easily digested and hence the } \\
\text { higher the GI value. For instance cooked and riper foods. }\end{array}$ \\
\hline \multirow{4}{*}{$\begin{array}{l}\text { Accompanying } \\
\text { food }\end{array}$} & Fiber & $\begin{array}{l}\text { Diets rich in soluble fiber (e.g. guar gum, pectin and sugar beet } \\
\text { fibers) can form gelatinous gels within the stomach which inhibit } \\
\mathrm{CHO} \text { absorption and digestion. So, fiber is thought to be able to } \\
\text { decrease GI. }\end{array}$ \\
\hline & $\begin{array}{l}\text { Sugars and } \\
\text { polyols }\end{array}$ & $\begin{array}{l}\text { Water binding sugars and polyols could restrict the amount of } \\
\text { water for starch gelatinization, which may decrease GI. }\end{array}$ \\
\hline & Acidity & $\begin{array}{l}\text { Increased acidity slows down the speed of gastric emptying and } \\
\mathrm{CHO} \text { digestion thereby reduces the GI value. For example, } \\
\text { vinegar could decrease GI and sourdough bread has a lower GI } \\
\text { than common bread. }\end{array}$ \\
\hline & Fat and protein & $\begin{array}{l}\text { Co-ingestion of fat and protein slows the rate of gastric emptying, } \\
\text { hence decreases the GI value. In addition, fat and protein could } \\
\text { also stimulate the insulin response and increase insulin } \\
\text { sensitivity. }\end{array}$ \\
\hline
\end{tabular}

Secondly, the rate at which different people digest CHOs varies substantially, and complicating things even more, a person's glycemic response may vary from 
time to time and different people may have different insulin responses even though they have identical glycemic responses. These factors cause that the GI of a food varies from person to person and from day to day. However, these variations in GI are random variations and do not detract the utility of GI (Wolever, personal communication).

And last, but not least, inter-laboratory differences in GI measurements are also of great concern. Many methodological variables markedly affect GI values, such as the amount of available CHOs tested, the choice of standard food, the number of standard tests and the frame of blood sampling (frequency and length). However, these variances could be reduced substantially by adopting standard measurement procedures. ${ }^{26,27}$ There are several laboratories around the world that claim to control the variation in GI values to an acceptable level using strict and specific protocols (see for example http://www.glycemicindextesting.com).

\section{Glycemic index and diabetes}

Diabetes is a metabolic disorder resulting from an imbalance between insulin availability and insulin need. This can be caused by absolute insulin deficiency or impaired insulin function. A person with uncontrolled diabetes is unable to transport glucose into fat and muscle cells; as a result, blood glucose is elevated, the body cells are starved and the breakdown of fat and protein is increased. It is well known that diabetes is associated with an increased risk of numerous serious, sometimes life-threatening complications, such as cardiovascular disease, diabetic ketoacidosis, neuropathy, retinopathy and a reduced quality of life..$^{28}$

Besides drug therapy, dietary management is still the cornerstone of diabetes management where the general goal is reducing body mass index (BMI) to the normal range, controlling blood glucose levels close to normal, preventing acute (e.g. hypoglycemia) and long term (e.g. cardiovascular) complications etc. In addition to the benefits on weight control, which will be explained later, low GI diets could also help to achieve the other aspects of the diabetes management goal.

\section{Controlling blood glucose level close to normal}

Considerable research, including two important meta-analyses, have revealed that low GI food consumption could induce improved glycemic control.29-34 In the meta-analysis conducted by Brand-Miller et al, it was found that low GI diets reduced $\mathrm{HbA}_{1 \mathrm{c}}$ by $0.43 \%$ points over and above that produced by high GI diets among 356 subjects from 14 randomized controlled trials in about 10 weeks. Taking both $\mathrm{HbA}_{1 \mathrm{c}}$ and fructosamine data together and adjusting for baseline differences, level of glycated proteins was reduced $7.4 \%$ more on the low GI diet than on the high GI diet. ${ }^{33}$ More recently, Opperman et al combined the results from 16 randomized controlled trials and found that low GI diets significantly reduced fructosamine by $0.1 \mathrm{mmol} / \mathrm{L}, \mathrm{HbA}_{1 \mathrm{c}}$ by $0.27 \%$ points, total cholesterol by $0.33 \mathrm{mmol} / \mathrm{L}$ and nonsignificantly reduced low density lipoprotein cholesterol (LDL) in type 2 diabetic 
subjects by $0.15 \mathrm{mmol} / \mathrm{L}$ compared with high-GI diets. ${ }^{34}$ Furthermore, a number of studies have demonstrated the benefit of fructose administration, which has a low GI, in diabetic control. ${ }^{35-38}$

\begin{tabular}{|c|c|c|c|c|}
\hline \multicolumn{5}{|c|}{ Table 2-2. Summary of the effects of low GI diets on the management of diabetes* } \\
\hline Publication & Study design & Subjects & Duration & Summary of the outcomes \\
\hline \multicolumn{5}{|c|}{ Studies supporting the beneficial effects of low GI diets } \\
\hline $\begin{array}{l}\text { Opperman, et al }{ }^{34} \\
\text { Br J Nutr, } 2004\end{array}$ & Meta-analysis ${ }^{+}$ & $\begin{array}{l}396 \text { subjects } \\
\text { from } 16 \\
\text { RCTs }\end{array}$ & $\begin{array}{l}12 \text { days } \\
\text { to } 6 \text { mths }\end{array}$ & $\begin{array}{l}\text { Compared to high GI diets, low GI } \\
\text { diets reduced fructosamine by } 0.1 \\
\text { mmol/L, HbAic by } 0.27 \% \text {, TC by } 0.33 \\
\text { mmol/L and LDL by } 0.15 \mathrm{mmol} / \mathrm{L} \text {. }\end{array}$ \\
\hline $\begin{array}{l}\text { Brand-Miller, et } \\
\text { al }^{33} \text { Diabetes Care, } \\
2003\end{array}$ & Meta-analysis $^{+}$ & $\begin{array}{l}356 \text { subjects } \\
\text { from } 14 \\
\text { RCTs }\end{array}$ & $10 \mathrm{wks}$ & $\begin{array}{l}\text { Compared with high GI diets, low GI } \\
\text { diets decreased HbAic by } 0.43 \% \text { in } \\
\text { about } 10 \text { wks and fructosamine by } 0.2 \\
\text { mmol/L in about } 4 \text { wks. }\end{array}$ \\
\hline $\begin{array}{l}\text { Rizkalla, et al }{ }^{39} \\
\text { Diabetes Care, } \\
2004\end{array}$ & $\begin{array}{l}\text { RCT (cross- } \\
\text { over design) }\end{array}$ & $\begin{array}{l}12 \mathrm{~T} 2 \mathrm{DM} \\
\text { men }\end{array}$ & 4 wks & $\begin{array}{l}\text { Low GI diet improved fasting glucose, } \\
\text { HbA1c, whole-body glucose } \\
\text { utilization, PAI-1 activity as well as } \\
\text { TC, LDL cholesterol, FFAs and apo B } \\
\text { concentrations. }\end{array}$ \\
\hline $\begin{array}{l}\text { Jimenez-Cruz, et } \\
\text { al }^{40} \text { Diabetes Care, } \\
2003\end{array}$ & $\begin{array}{l}\text { RCT (cross- } \\
\text { over design) }\end{array}$ & $\begin{array}{l}14 \text { subjects } \\
\text { with T2DM }\end{array}$ & 6 wks & $\begin{array}{l}\text { Compared to the high GI diet, the low } \\
\text { GI diet resulted in more reduction in } \\
\text { fasting glucose and } \mathrm{HbA} \text { ic. }\end{array}$ \\
\hline $\begin{array}{l}\text { Jarvi, et al }{ }^{41} \\
\text { Diabetes Care, } \\
1999\end{array}$ & $\begin{array}{l}\text { RCT (cross- } \\
\text { over design) }\end{array}$ & $\begin{array}{l}20 \mathrm{~T} 2 \mathrm{DM} \\
\text { patients }\end{array}$ & 24 days & $\begin{array}{l}\text { In contrast to the high GI diet, the low } \\
\text { GI diet induced more favorable } \\
\text { changes in blood insulin, glucose, C- } \\
\text { peptide, cholesterol, apoB, apoA-1, } \\
\text { and PAI-1 activity. }\end{array}$ \\
\hline $\begin{array}{l}\text { Fontvielle, et al }{ }^{29} \\
\text { Diabetic Med, } \\
1992\end{array}$ & $\begin{array}{l}\text { RCT (cross- } \\
\text { over design) }\end{array}$ & $\begin{array}{l}18 \text { diabetic } \\
\text { patients }\end{array}$ & $5 \mathrm{wks}$ & $\begin{array}{l}\text { Compared to the high GI diet, the low } \\
\text { GI diet led to improved glycemic } \\
\text { control and TG levels }\end{array}$ \\
\hline $\begin{array}{l}\text { Qi, et } \text { al }^{42} \\
\text { Diabetes Care, } \\
2005\end{array}$ & $\begin{array}{l}\text { Cross- } \\
\text { sectional } \\
\text { study }\end{array}$ & $\begin{array}{l}780 \text { diabetic } \\
\text { patients }\end{array}$ & - & $\begin{array}{l}\text { Dietary GI was inversely associated } \\
\text { with adiponectin concentration. }\end{array}$ \\
\hline $\begin{array}{l}\text { Buyken, et al }{ }^{43} \\
\text { Am J Clin Nutr, } \\
2001\end{array}$ & $\begin{array}{l}\text { Cross- } \\
\text { sectional } \\
\text { study }\end{array}$ & $\begin{array}{l}2810 \text { people } \\
\text { with T1DM }\end{array}$ & - & $\begin{array}{l}\text { Dietary GI was positively related to } \\
\text { HbA1c concentration and inversely } \\
\text { related to HDL cholesterol } \\
\text { concentration. }\end{array}$ \\
\hline \multicolumn{5}{|c|}{ Studies that failed to show beneficial effects of low GI diets } \\
\hline $\begin{array}{l}\text { Calle-Pascual, et } \\
\text { al }^{44} \text { Diabet Metab, } \\
1988\end{array}$ & $\begin{array}{l}\text { RCT (cross- } \\
\text { over design) }\end{array}$ & $\begin{array}{l}24 \text { diabetic } \\
\text { patients }\end{array}$ & 4 wks & $\begin{array}{l}\text { No difference was found in insulin } \\
\text { dose, weight change and } \mathrm{HbA} 1 \mathrm{c} \\
\text { levels }\end{array}$ \\
\hline \multicolumn{5}{|c|}{$\begin{array}{l}\text { * Ordered by study design and publication year (most recent first) } \\
\text { + Meta-analysis, the results of single studies on glycemic control are not presented in this table. } \\
\text { apoA: Apolipoprotein A, apoB: Apolipoprotein B, FFA: Free fatty acids, GI: Glycemic index, HbA1c: Glycated } \\
\text { haemoglobin, HDL: High density lipoprotein cholesterol, LDL: Low density lipoprotein cholesterol, PAI-1: } \\
\text { Plasminogen activator inhibitor 1, RCT: Randomized controlled trial, TC: Total cholesterol, T1DM: Type } 1 \\
\text { diabetes, T2DM: Type } 2 \text { diabetes, TG: Triglycerides. }\end{array}$} \\
\hline
\end{tabular}


Preventing acute complications such as hypoglycemia

As shown in Figure 2-1, low GI foods cause lower peaks and less fluctuation in postprandial blood glucose levels than foods with high GI values. Therefore, low or medium GI foods are often recommended to diabetes patients for the prevention of hypoglycemia. ${ }^{2,3}$

Preventing long term complications such as cardiovascular disease

It has been acknowledged that insulin resistance, postprandial hyperglycemia and dislipidemia are strong risk factors for cardiovascular disease in diabetes patients. ${ }^{45}$ Several studies, including a meta-analysis, ${ }^{34}$ several randomized controlled trials ${ }^{29,39,41}$ and observational studies, ${ }^{42,43}$ have related the consumption of low GI diets to an improved cardiovascular risk profile in patients with diabetes, reflecting favorable levels of high density lipoprotein cholesterol (HDL), triglycerides (TG), LDL, C-reactive protein (CRP) and adiponectin. These findings stress the importance of low GI diets, along with other lifestyle adaptations, in reducing the risk of macrovascular complications of diabetes. ${ }^{46}$

In Table 2-2, results from published clinical trials and epidemiological studies relating dietary GI to the management of diabetes are listed. In summary, two metaanalyses, 33,34 four additional randomized controlled trials that were not included in the meta-analyses, ${ }^{29}, 39-41$ two large-scale cross-sectional studies support the beneficial effects of low GI diets on diabetic control. ${ }^{42,} 43$ However, there is also one randomized controlled trial that did not find favorable impacts of low GI diets on insulin dose, weight change and $\mathrm{HbA}_{1 \mathrm{c}}$ level. ${ }^{4}$

\begin{tabular}{|c|c|c|c|c|}
\hline \multicolumn{5}{|c|}{ Table 2-3. Summary of the effects of low GI diets on type 2 diabetes risk factors* } \\
\hline Publication & Study design & Subjects & Duration & Summary of the outcomes \\
\hline \multicolumn{5}{|c|}{ Studies supporting the beneficial effects of low GI diets } \\
\hline $\begin{array}{l}\text { Laaksonen, } \\
\text { et al }{ }^{47} \\
\text { Am J Clin } \\
\text { Nutr, } 2005\end{array}$ & $\begin{array}{l}\text { RCT (parallel } \\
\text { design) }\end{array}$ & $\begin{array}{l}72 \text { adults with the } \\
\text { metabolic } \\
\text { syndrome }\end{array}$ & 12 wks & $\begin{array}{l}\text { The insulinogenic index increased } \\
\text { more in the rye bread and pasta } \\
\text { group than in the oat and wheat } \\
\text { bread and potato group. }\end{array}$ \\
\hline $\begin{array}{l}\text { Brynes, et al }{ }^{48} \\
\text { Br J Nutr, } \\
2003\end{array}$ & $\begin{array}{l}\text { RCT (cross- } \\
\text { over design) }\end{array}$ & $\begin{array}{l}17 \text { men with cardiac } \\
\text { risk factors }\end{array}$ & 24 days & $\begin{array}{l}\text { The low GI diet led to more } \\
\text { favorable postprandial glucose and } \\
\text { insulin levels than the high GI diet. }\end{array}$ \\
\hline $\begin{array}{l}\text { Wolever, et } \\
\text { al }{ }^{49} \text { Am J Clin } \\
\text { Nutr, } 2003\end{array}$ & $\begin{array}{l}\text { RCT (parallel } \\
\text { design) }\end{array}$ & 35 subjects with IGT & 4 mths & $\begin{array}{l}\text { Compared to the high GI } \\
\text { counterpart, the low GI diet induced } \\
\text { more postprandial glucose decreases. }\end{array}$ \\
\hline $\begin{array}{l}\text { Seewi, et al }{ }^{50} \\
\text { Eur J Nutr, } \\
1999\end{array}$ & $\begin{array}{l}\text { RCT (cross- } \\
\text { over design) }\end{array}$ & 26 healthy subjects & $6 \mathrm{hrs}$ & $\begin{array}{l}\text { Low GI pea starch elicited less } \\
\text { hyperglycemia, hyperinsulinemia } \\
\text { and C-peptide secretion as compared } \\
\text { to corn starch. }\end{array}$ \\
\hline $\begin{array}{l}\text { Slabber, et } \\
\text { al }^{51} \\
\text { Am J Clin } \\
\text { Nutr, } 1994\end{array}$ & $\begin{array}{l}\text { RCT (parallel } \\
\& \text { cross-over) }\end{array}$ & $\begin{array}{l}30 \text { obese women } \\
\text { with hyper- } \\
\text { insulinemia }\end{array}$ & $12 \mathrm{wks}$ & $\begin{array}{l}\text { Fasting and postprandial insulin } \\
\text { decreased and insulin: C-peptide } \\
\text { ratio increased more after a low GI } \\
\text { diet compared with a high GI diet. }\end{array}$ \\
\hline
\end{tabular}




\begin{tabular}{|c|c|c|c|c|}
\hline $\begin{array}{l}\text { Schulze, et } \\
\text { al }^{52} \text { Am J Clin } \\
\text { Nutr, } 2004\end{array}$ & $\begin{array}{l}\text { Prospective } \\
\text { cohort study }\end{array}$ & $\begin{array}{l}91249 \text { US female } \\
\text { nurses }\end{array}$ & 8 yrs & $\begin{array}{l}\text { Dietary GI was positively associated } \\
\text { with the risk of T2DM (RR of the } \\
\text { highest quintile }=1.59 \text { ) }\end{array}$ \\
\hline $\begin{array}{l}\text { Hodge, et al }{ }^{53} \\
\text { Diabetes } \\
\text { Care, } 2004\end{array}$ & $\begin{array}{l}\text { Prospective } \\
\text { cohort study }\end{array}$ & $\begin{array}{l}31641 \text { non-diabetic } \\
\text { Australian adults }\end{array}$ & 4 yrs & $\begin{array}{l}\text { Dietary GI was positively associated } \\
\text { with the risk of T2DM (OR per } 10 \\
\text { units } G I=1.32 \text { ) }\end{array}$ \\
\hline $\begin{array}{l}\text { Salmeron, et } \\
\mathrm{al}^{9} \\
\text { JAMA, } 1997\end{array}$ & $\begin{array}{l}\text { Prospective } \\
\text { cohort study }\end{array}$ & $\begin{array}{l}65173 \text { US female } \\
\text { nurses }\end{array}$ & 6 yrs & $\begin{array}{l}\text { Dietary GI was positively associated } \\
\text { with risk of T2DM (RR of the highest } \\
\text { quintile }=1.37 \text { ) }\end{array}$ \\
\hline $\begin{array}{l}\text { Salmeron, et } \\
\text { al }{ }^{54} \text { Diabetes } \\
\text { Care, } 1997\end{array}$ & $\begin{array}{l}\text { Prospective } \\
\text { cohort study }\end{array}$ & $\begin{array}{l}42759 \text { US male } \\
\text { health professionals }\end{array}$ & 6 yrs & $\begin{array}{l}\text { Dietary GI was positively associated } \\
\text { with risk of T2DM (RR of the highest } \\
\text { quintile }=1.37 \text { ) }\end{array}$ \\
\hline $\begin{array}{l}\text { McKeown, et } \\
\text { al } 55 \\
\text { Diabetes } \\
\text { Care, } 2004\end{array}$ & $\begin{array}{l}\text { Cross- } \\
\text { sectional } \\
\text { study }\end{array}$ & 2834 US subjects & - & $\begin{array}{l}\text { Dietary GI was positively associated } \\
\text { with insulin resistance and the } \\
\text { prevalence of the metabolic } \\
\text { syndrome (OR of highest quintile = } \\
\text { 1.41). }\end{array}$ \\
\hline \multicolumn{5}{|c|}{ Studies that failed to show beneficial effects of low GI diets } \\
\hline $\begin{array}{l}\text { Stevens, et } \\
\text { al }^{56} \text { Diabetes } \\
\text { Care, } 2002\end{array}$ & $\begin{array}{l}\text { Prospective } \\
\text { cohort study }\end{array}$ & $\begin{array}{l}12251 \quad \text { African- } \\
\text { American and } \\
\text { white adults }\end{array}$ & 9 yrs & $\begin{array}{l}\text { No statistically significant } \\
\text { association between dietary GI and } \\
\text { the incidence of diabetes was found }\end{array}$ \\
\hline $\begin{array}{l}\text { Meyer, et al }{ }^{57} \\
\text { Am J Clin } \\
\text { Nutr, } 2000\end{array}$ & $\begin{array}{l}\text { Prospective } \\
\text { cohort study }\end{array}$ & 35988 US women & 6 yrs & $\begin{array}{l}\text { Failed to find a predictive impact of } \\
\text { dietary GI on the incidence of } \\
\text { diabetes }\end{array}$ \\
\hline $\begin{array}{l}\text { van } \text { Dam, et } \\
\text { al }^{58} \text { Eur J } \\
\text { Clin Nutr, } \\
2000\end{array}$ & $\begin{array}{l}\text { Prospective } \\
\text { cohort study }\end{array}$ & 646 Dutch men & 10 yrs & $\begin{array}{l}\text { GI was not appreciably associated } \\
\text { with (fasting or post-load) insulin } \\
\text { and glucose levels. }\end{array}$ \\
\hline $\begin{array}{l}\text { Liese, et al }{ }^{59} \\
\text { Diabetes } \\
\text { Care, } 2005\end{array}$ & $\begin{array}{l}\text { Cross- } \\
\text { sectional } \\
\text { study }\end{array}$ & 970 adults & - & $\begin{array}{l}\text { No association was found between } \\
\text { GI / GL and insulin sensitivity and } \\
\text { insulin secretion. }\end{array}$ \\
\hline $\begin{array}{l}\text { Lau, et al }{ }^{60} \\
\text { Diabetes } \\
\text { Care, } 2005\end{array}$ & $\begin{array}{l}\text { Cross- } \\
\text { sectional } \\
\text { study }\end{array}$ & $\begin{array}{l}5675 \text { non-diabetic } \\
\text { Danish adults }\end{array}$ & - & $\begin{array}{l}\text { Dietary GI and } \mathrm{CHO} \text { intake were not } \\
\text { associated with insulin resistance. }\end{array}$ \\
\hline
\end{tabular}

*Ordered by study design and publication year (most recent first)

CHO: Carbohydrate, GI: Glycemic index, GL: Glycemic load, HbA1c: Glycated hemoglobin, HOMA-IR: Insulin resistance from homeostasis model assessment, IGT: Impaired glucose tolerance, OR: Odds ratio, RCT: Randomized controlled trial, RR: Relative risk, T2DM: Type 2 diabetes.

Moreover, low GI foods may also play an important role in preventing type 2 diabetes. This is supported by the results from animal studies, ${ }^{61-63}$ randomized controlled trials ${ }^{48,}, 49$ and large-scale long-term cohort studies. .94 As listed in Table 2-3, five randomized controlled trials $47-51$ and four prospective cohort studies, 52-54 and one cross-sectional study ${ }^{55}$ found a beneficial impact of low GI foods on the risk factors of developing type 2 diabetes, but no consensus has been reached. Three prospective cohort studies ${ }^{56-58}$ and two large cross-sectional studies ${ }^{59,60}$ failed to find significant beneficial effect of low GI diet on the incidence of type 2 diabetes as well as insulin sensitivity level. The authors of one of these papers, however, 
acknowledge that the failure to detect an association might be due to using a limited 66-item semi-quantitative food-frequency questionnaire to assess diets. ${ }^{56}$

Given the aforementioned evidence supporting the benefits of low GI diets on diabetes prevention and management, the use of GI concept has now been endorsed by the British Dietetic Association, ${ }^{64}$ Diabetes UK, ${ }^{65}$ the European Association for the Study of Diabetes, ${ }^{66}$ the Canadian Diabetes Association ${ }^{67}$ and the World Health Organisation. ${ }^{4}$

Table 2-4. Summary of the effects of low GI diets on weight or body composition change*

\begin{tabular}{|c|c|c|c|c|}
\hline Publication & Study design & Subjects & Duration & Summary of the outcomes \\
\hline \multicolumn{5}{|c|}{ Studies supporting the beneficial effects of low GI diets } \\
\hline $\begin{array}{l}\text { Brynes, et al }{ }^{48} \\
\text { Br J Nutr, } \\
2003\end{array}$ & $\begin{array}{l}\text { RCT (cross } \\
\text { over design) }\end{array}$ & $\begin{array}{l}17 \text { middle-aged } \\
\text { men with one or } \\
\text { more cardiac risk } \\
\text { factors }\end{array}$ & 24 days & $\begin{array}{l}\text { The low GI diet group had lowest } \\
\text { daily energy intake and more } \\
\text { favorable weight change compared } \\
\text { to high fat, high sucrose and high } \\
\text { GI groups. }\end{array}$ \\
\hline $\begin{array}{l}\text { Jimenez- } \\
\text { Cruz, et al }{ }^{40} \\
\text { Diabetes } \\
\text { Care, } 2003\end{array}$ & $\begin{array}{l}\text { RCT (cross- } \\
\text { over design) }\end{array}$ & $\begin{array}{l}14 \text { Mexican } \\
\text { overweight or } \\
\text { obese subjects with } \\
\text { T2DM }\end{array}$ & 6 wks & $\begin{array}{l}\text { Compared to the high GI diet, the } \\
\text { low GI diet induced more reduction } \\
\left.\text { in BMI ( } 0.6 \mathrm{vs} .0 \mathrm{~kg} / \mathrm{m}^{2}\right) \text { and body } \\
\text { weight ( } 1.5 \mathrm{vs} .0 .6 \mathrm{~kg}) \text {. }\end{array}$ \\
\hline $\begin{array}{l}\text { Bouche, et } \mathrm{al}^{7} \\
\text { Diabetes } \\
\text { Care, } 2002\end{array}$ & $\begin{array}{l}\text { RCT(cross- } \\
\text { over design) }\end{array}$ & 11 healthy men & $5 \mathrm{wks}$ & $\begin{array}{l}\text { The low GI diet induced a } \sim 700 \mathrm{~g} \text { fat } \\
\text { mass reduction and an improved } \\
\text { lipid profile. }\end{array}$ \\
\hline $\begin{array}{l}\text { Slabber, et } \\
\text { al51 } \\
\text { Am J Clin } \\
\text { Nutr, } 1994\end{array}$ & $\begin{array}{l}\text { RCT(parallel } \\
\text { study; } \\
16 \text { of } 30 \text { also } \\
\text { cross-over) }\end{array}$ & $\begin{array}{l}30 \text { obese females } \\
\text { with } \\
\text { hyperinsulinemia }\end{array}$ & $12 \mathrm{wks}$ & $\begin{array}{l}\text { The low GI energy-restricted diet } \\
\text { led to more weight loss and greater } \\
\text { reduction in BMI compared to the } \\
\text { high GI counter diet. }\end{array}$ \\
\hline $\begin{array}{l}\text { Spieth, et al }{ }^{68} \\
\text { Arch Pediat } \\
\text { Adol Med, } \\
2000 \text {. }\end{array}$ & $\begin{array}{l}\text { Non-random } \\
\text { parallel study }\end{array}$ & 107 obese children & $4 \mathrm{mths}$ & $\begin{array}{l}\text { The low GI diet induced greater } \\
\text { reduction in BMI and body weight } \\
\text { compared with the conventional } \\
\text { reduced-fat diet. }\end{array}$ \\
\hline $\begin{array}{l}\text { Bahadori, et } \\
\text { al }{ }^{69} \text { Diabetes } \\
\text { Obes Meta, } \\
2005\end{array}$ & $\begin{array}{l}\text { Uncontrolled } \\
\text { intervention } \\
\text { study }\end{array}$ & $\begin{array}{l}109 \text { obese patients } \\
\text { from obesity } \\
\text { outpatient clinics }\end{array}$ & 6 mths & $\begin{array}{l}\text { The low fat low GI diet led to a } \\
\text { significant reduction of fat mass. }\end{array}$ \\
\hline $\begin{array}{l}\text { Toeller, et al }{ }^{70} \\
\text { Int J Obes } \\
\text { Relat Meta } \\
\text { Disord, } 2001\end{array}$ & $\begin{array}{l}\text { Cross- } \\
\text { sectional } \\
\text { study }\end{array}$ & $\begin{array}{l}2868 \text { patients with } \\
\text { T1DM }\end{array}$ & - & $\begin{array}{l}\text { Dietary GI was positively correlated } \\
\text { with body waist-to-hip ratio and } \\
\text { waist circumference. }\end{array}$ \\
\hline \multicolumn{5}{|c|}{ Studies that failed to show beneficial effects of low GI diets } \\
\hline $\begin{array}{l}\text { Raatz, et al71 } \\
\text { J. Nutr. } 2005\end{array}$ & $\begin{array}{l}\text { RCT (parallel } \\
\text { design) }\end{array}$ & 29 obese subjects & $36 \mathrm{wks}$ & $\begin{array}{l}\text { The low GI diet group experienced } \\
\text { a slightly greater but not statistically } \\
\text { significant reduction in weight, BMI } \\
\text { and fat mass than high GI and high } \\
\text { fat groups. }\end{array}$ \\
\hline $\begin{array}{l}\text { Carels, et al }{ }^{72} \\
\text { Eat Behav, } \\
2005\end{array}$ & $\begin{array}{l}\text { RCT (parallel } \\
\text { design) }\end{array}$ & 53 obese adults & $\begin{array}{l}20 \text { wks } \\
\text { treatment } \\
\text { and } 1 \text { year }\end{array}$ & $\begin{array}{l}\text { Low GI diets achieved via GI } \\
\text { education had no significant impact } \\
\text { on weight loss treatment outcomes }\end{array}$ \\
\hline
\end{tabular}




\begin{tabular}{|c|c|c|c|c|}
\hline & & & follow up & $\begin{array}{l}\text { at post treatment or } 1 \text {-year follow- } \\
\text { up. }\end{array}$ \\
\hline $\begin{array}{l}\text { Sloth, et al }{ }^{73} \\
\text { Am J Clin } \\
\text { Nutr, } 2004\end{array}$ & $\begin{array}{l}\text { RCT (parallel } \\
\text { design) }\end{array}$ & $\begin{array}{l}45 \text { healthy } \\
\text { overweight } \\
\text { women }\end{array}$ & $10 \mathrm{wks}$ & $\begin{array}{l}\text { Low GI diet induced only slightly, } \\
\text { but not significantly greater } \\
\text { reduction in energy intake, body } \\
\text { weight, fat mass than did high GI } \\
\text { diet. }\end{array}$ \\
\hline $\begin{array}{l}\text { Rizkalla, et } \\
\text { al }^{39} \text { Diabetes } \\
\text { Care, } 2004\end{array}$ & $\begin{array}{l}\text { RCT (cross- } \\
\text { over design) }\end{array}$ & 12 T2DM patients & 4 wks & $\begin{array}{l}\text { No difference in body weight, BMI, } \\
\text { fat and lean body mass was found. }\end{array}$ \\
\hline $\begin{array}{l}\text { Wolever } \\
\text { Diabetes } \\
\text { Care, } 1992\end{array}$ & $\begin{array}{l}\text { RCT (cross- } \\
\text { over design) }\end{array}$ & 6 T2DM patients & $6 \mathrm{wks}$ & $\begin{array}{l}\text { A small and similar amount of } \\
\text { weight was lost on both diets. }\end{array}$ \\
\hline $\begin{array}{l}\text { Jenkins, et } \\
\mathrm{al}^{75} \text { Am J Clin } \\
\text { Nutr, } 1988\end{array}$ & $\begin{array}{l}\text { RCT (cross- } \\
\text { over design) }\end{array}$ & $\begin{array}{l}8 \text { patients with } \\
\text { T2DM }\end{array}$ & 2 wks & $\begin{array}{l}\text { Both high and low GI diets induced } \\
\text { weight loss but the reduction in low } \\
\text { GI group was smaller. }\end{array}$ \\
\hline $\begin{array}{l}\text { Liese, et al }{ }^{59} \\
\text { Diabetes } \\
\text { Care, } 2005\end{array}$ & $\begin{array}{l}\text { Cross- } \\
\text { sectional } \\
\text { study }\end{array}$ & $\begin{array}{l}970 \text { adults with } \\
\text { normal or } \\
\text { impaired glucose }\end{array}$ & - & $\begin{array}{l}\text { No association was found between } \\
\text { GI / GL and adiposity (BMI and } \\
\text { waist circumference). }\end{array}$ \\
\hline
\end{tabular}

\section{Glycemic index and obesity}

The prevalence of obesity $\left(\mathrm{BMI} \geq 30 \mathrm{~kg} / \mathrm{m}^{2}\right)$ and overweight $\left(\mathrm{BMI} \geq 25 \mathrm{~kg} / \mathrm{m}^{2}\right)$ is rapidly increasing worldwide. It has been found that obesity, and to a lesser extent overweight, is associated with an increased risk of mortality and morbidity from metabolic syndrome, type 2 diabetes, cardiovascular disease, gastrointestinal disorders and several malignancies. ${ }^{76}$

Because a low GI diet could promote satiety and fat oxidation, it is believed to benefit weight control. According to Brand-Miller et al, low GI diets, characterized by slow digestion and absorption rates, could persistently stimulate the nutrient receptors in the gastrointestinal tract, so could result in a prolonged feedback, via satiety signals such as cholecystokinin (CCK) and glucagon-like peptide-1 (GLP-1), to the satiety centre in the hypothalamus. ${ }^{77}$ In addition, at middle postprandial stage, the low levels of blood glucose and free fatty acids, which is often following the high GI consumption, often cause hunger and stimulate food intake.,27 Many published studies support the effects of low GI foods as compared to high GI foods, on a delayed return of hunger, decreased subsequent food intake, and increased satiety. ${ }^{13}$, 78-82 However, others are unable to demonstrate these effects. For example, in one randomized controlled trial, ${ }^{22}$ no significant differences in plasma glucose or insulin responses, appetitive ratings, or food intake between low and high GI groups were observed.

With regard to the effects of low GI foods on weight change and obesity, evidence from animal studies shows that high GI feeding is associated with higher fat mass, ${ }^{61}$ more visceral fat ${ }^{61,83}$ and increased adipocyte size. ${ }^{6,84}$ As summarized in 
Table 2-4, results from six prospective studies (including intervention and cohort studies) $7,40,48,51,68,69$ suggest that low GI diets result in more weight or fat loss than high GI diets. This is supported by the cross-sectional analysis from the EURODIAB Complications Study in which low GI diets are independently correlated with a smaller waist-to-hip ratio and waist circumference in men..$^{70}$ Unsurprisingly, there are also several studies that did not report beneficial effects of low GI diets on weight change. $39,59,71-75$ However, in some of these studies, low GI diets actually induce slightly more weight reduction compared to the high GI control and the failure to reach statistical significance in these studies might be due to a small sample size, hence a low statistical power. ${ }^{71,73}$ In one study, it was found that patients on low GI diets lost less weight than those on high GI diets. ${ }^{75}$ The fact that low GI group was given meals containing greater amount of total energy than high GI group should be taken into account. Large-scale long-term randomized controlled trials as well as prospective cohort studies investigating the effects of low GI diets on the prevention and treatment of obesity, such as the Diogenes study, are currently underway (http://www.diogenes-eu.org).

\section{Glycemic index and cardiovascular disease}

Cardiovascular disease, primarily heart disease and stroke, is one of the leading causes of death in both men and women around the world. Reducing fat intake hence decreasing blood lipid levels has been recognized as the key dietary strategy to prevent the incidence and progression of cardiovascular disease. However, it has been found that increasing $\mathrm{CHO}$ intake, which is often the case when fat should be constrained, but without considering the quality of $\mathrm{CHO}$ might not be a good choice to reduce cardiovascular disease incidences. ${ }^{85}$ Postprandial hyperglycemia caused by habitual high $\mathrm{CHO}$ high GI diets has been acknowledged as a significant risk factor of cardiovascular disease. ${ }^{25,86,87}$ The biological mechanisms behind this association might be through increased oxidative stress induced by high levels of blood glucose. Several lines of evidence have shown that high blood glucose levels could increase reactive oxygen species (ROS), which may in turn lead to the oxidation of membrane lipids, proteins, lipoproteins and DNA, damage endothelial function and activate inflammation. ${ }^{2}, 88$ Hyperinsulinemia may also be involved in the development of cardiovascular disease through hypertension because high insulin levels and insulin resistance could induce arterial stiffness and augmented generation, availability and subsequent application of ROS.89-92 In addition, hypoglycemia, which often occurs in the middle postprandial stage following a high GI meal, was also believed to be one of the most important risk factors of cardiovascular disease. That is because hypoglycemia could stimulate the release of counter-regulatory hormones and cause a marked increase in free fatty acids at the late postprandial stage, which could promote the incidence and progress of cardiovascular disease..$^{33}$

Many groups around the world have investigated the relationship between dietary GI and the risk factors of cardiovascular disease in animals and humans. 
They observed that low GI diets, as compared to high GI diets, induce lower levels of triglycerides ${ }^{7,} 61$ and LDL cholesterol, $, 94,95$ higher levels of HDL cholesterol ${ }^{96}$ and adiponectin ${ }^{42,61}$ and favorable changes in other cardiovascular risk factors like the haemostatic factor Plasminogen Activator Inhibitor-1 (PAI-1) and C-reactive protein (CRP) ${ }^{41,97}$ However, as shown in Table 2-5, the findings are far from consistent. The most important underlying reason for these opposite findings might be the methodology used to assign GI values to different food items. As already mentioned

\begin{tabular}{|c|c|c|c|c|}
\hline Publication & Design & Subjects & Duration & Summary of the outcomes \\
\hline \multicolumn{5}{|c|}{ Studies supporting the beneficial effects of low GI diets } \\
\hline $\begin{array}{l}\text { Ebbeling, et al }{ }^{98} \\
\text { Am J Clin Nutr, } \\
2005\end{array}$ & $\begin{array}{l}\text { RCT (parallel } \\
\text { design), Pilot } \\
\text { study }\end{array}$ & $\begin{array}{l}23 \text { obese young } \\
\text { adults }\end{array}$ & 12 mths & $\begin{array}{l}\text { Compared to the low fat group, the } \\
\text { low GL/GI group showed a } \\
\text { significantly greater decline in } \\
\text { plasma level of TG and PAI-1. }\end{array}$ \\
\hline $\begin{array}{l}\text { Pereira, et } \text { al }^{97} \\
\text { JAMA, } 2004\end{array}$ & $\begin{array}{l}\text { RCT (parallel } \\
\text { design) }\end{array}$ & $\begin{array}{l}39 \text { overweight or } \\
\text { obese young } \\
\text { adults }\end{array}$ & $\begin{array}{l}\text { 2 mths } \\
(10 \% \\
\text { weight } \\
\text { loss })\end{array}$ & $\begin{array}{l}\text { Compared to low fat diet, energy } \\
\text { restricted low GL/GI diet induced } \\
\text { favorable changes (\%) in resting } \\
\text { energy expenditure, self-reported } \\
\text { hunger, serum TG, HOMA-IR, CRP } \\
\text { and blood pressure. }\end{array}$ \\
\hline $\begin{array}{l}\text { Sloth, et al73 } \\
\text { Am J Clin Nutr, } \\
2004\end{array}$ & $\begin{array}{l}\text { RCT (parallel } \\
\text { design) }\end{array}$ & $\begin{array}{l}45 \text { healthy } \\
\text { overweight } \\
\text { women }\end{array}$ & $10 \mathrm{wks}$ & $\begin{array}{l}\text { Compared with the high GI group, } \\
\text { the low GI diet induced a larger } \\
\text { reduction in LDL and TC. }\end{array}$ \\
\hline $\begin{array}{l}\text { Harbis, et al }{ }^{99} \\
\text { Am J Clin Nutr, } \\
2004\end{array}$ & $\begin{array}{l}\text { RCT (parallel } \\
\text { design) }\end{array}$ & $\begin{array}{l}9 \text { subjects with } \\
\text { central obesity } \\
\text { and insulin } \\
\text { resistance }\end{array}$ & $\begin{array}{l}6 \text { hrs } \\
\text { after } \\
\text { meal }\end{array}$ & $\begin{array}{l}\text { Mixed meals containing slowly } \\
\text { digestible (low GI) CHO induced } \\
\text { low glycemic and insulinemic } \\
\text { responses, plasma TG, apoB- } 48 \text { and } \\
\text { apoB-100. }\end{array}$ \\
\hline $\begin{array}{l}\text { Patel, et al }{ }^{100} \\
\text { J Hum Nutr Diet. } \\
2004\end{array}$ & $\begin{array}{l}\text { RCT (parallel } \\
\text { design) }\end{array}$ & $\begin{array}{l}35 \text { adult subjects } \\
\text { with CHD } \\
\text { awaiting bypass }\end{array}$ & 4 wks & $\begin{array}{l}\text { Patients in the low GI group had } \\
\text { improved glucose tolerance and } \\
\text { significantly greater in vitro } \\
\text { adipocyte insulin sensitivity at the } \\
\text { time of surgery and shorter hospital } \\
\text { stay compared with those in high } \\
\text { GI group. }\end{array}$ \\
\hline $\begin{array}{l}\text { Brynes, et al }{ }^{48} \\
\text { Br J Nutr, } 2003\end{array}$ & $\begin{array}{l}\text { RCT (cross } \\
\text { over design) }\end{array}$ & $\begin{array}{l}17 \text { middle-aged } \\
\text { men with one or } \\
\text { more cardiac } \\
\text { risk factors }\end{array}$ & 24 days & $\begin{array}{l}\text { Compared with macronutrient- } \\
\text { matched high GI diet, low GI diet } \\
\text { induced greater reduction in } \\
\text { postprandial HOMA-IR. }\end{array}$ \\
\hline $\begin{array}{l}\text { Dumesnil, et al }{ }^{101} \\
\text { Br J Nutr, } 2001\end{array}$ & $\begin{array}{l}\text { RCT (cross- } \\
\text { over design) }\end{array}$ & $\begin{array}{l}12 \text { overweight } \\
\text { men }\end{array}$ & 6 days & $\begin{array}{l}\text { Waist and hip circumferences, } \\
\text { plasma TG level, LDL particle size } \\
\text { and fasting insulin concentrations } \\
\text { changed favorably by low GI diets. }\end{array}$ \\
\hline $\begin{array}{l}\text { Frost, et al }{ }^{102} \\
\text { Metabolism, } 1998\end{array}$ & $\begin{array}{l}\text { RCT (parallel } \\
\text { design) }\end{array}$ & 61 women & 3 wks & $\begin{array}{l}\text { Compared to the high GI diet, the } \\
\text { low GI counterpart improved } \\
\text { insulin sensitivity. }\end{array}$ \\
\hline
\end{tabular}




\begin{tabular}{|c|c|c|c|c|}
\hline $\begin{array}{l}\text { Sciarrone, et al }{ }^{103} \\
\text { J Hypertens, } 1993\end{array}$ & $\begin{array}{l}\text { RCT (parallel } \\
\text { design) }\end{array}$ & $\begin{array}{l}20 \text { healthy male } \\
\text { volunteers }\end{array}$ & $6 \mathrm{wks}$ & $\begin{array}{l}\text { Low GI was associated with lower } \\
\text { ambulatory blood pressure and } \\
\text { lower heart rate. }\end{array}$ \\
\hline $\begin{array}{l}\text { Brynes, et al }{ }^{104} \\
\text { Br J Nutr, } 2005\end{array}$ & $\begin{array}{l}\text { Uncontrolled } \\
\text { intervention } \\
\text { study }\end{array}$ & $\begin{array}{l}9 \text { healthy } \\
\text { subjects }\end{array}$ & $1 \mathrm{wk}$ & $\begin{array}{l}\text { The low GI diet induced a } \\
\text { significantly improved } 24 \text { hour } \\
\text { glucose profile, including fasting } \\
\text { glucose, mean glucose, area under } \\
24 \mathrm{~h} \text { glucose curve and area under } \\
8 \text { h glucose curve. }\end{array}$ \\
\hline $\begin{array}{l}\text { Liu, et al }{ }^{86} \\
\text { Am J Clin Nutr, } \\
2000\end{array}$ & $\begin{array}{l}\text { Prospective } \\
\text { cohort study }\end{array}$ & $\begin{array}{l}75521 \text { US female } \\
\text { nurses }\end{array}$ & $10 \mathrm{yrs}$ & $\begin{array}{l}\text { GI was associated with the risk of } \\
\text { CHD in a multivariate model (RR of } \\
\text { the highest quintile }=1.31 \text { ). }\end{array}$ \\
\hline $\begin{array}{l}\text { McKeown, et al }{ }^{55} \\
\text { Diabetes Care, } \\
2004\end{array}$ & $\begin{array}{l}\text { Cross- } \\
\text { sectional } \\
\text { study }\end{array}$ & 2834 US subjects & - & $\begin{array}{l}\text { GI was positively associated with } \\
\text { HOMA-IR and the prevalence of } \\
\text { the metabolic syndrome. }\end{array}$ \\
\hline $\begin{array}{l}\text { Ford, et al }{ }^{105} \\
\text { Arch Intern Med, } \\
2001\end{array}$ & $\begin{array}{l}\text { Cross- } \\
\text { sectional } \\
\text { study }\end{array}$ & 13907 US adults & - & $\begin{array}{l}\text { GI was inversely correlated with } \\
\text { HDL. }\end{array}$ \\
\hline $\begin{array}{l}\text { Frost, et al }{ }^{96} \\
\text { Lancet, } 1999\end{array}$ & $\begin{array}{l}\text { Cross- } \\
\text { sectional } \\
\text { study }\end{array}$ & $\begin{array}{l}1420 \text { British } \\
\text { adults }\end{array}$ & - & $\begin{array}{l}\text { Dietary GI was the only dietary } \\
\text { factor significantly related to serum } \\
\text { HDL. }\end{array}$ \\
\hline \multicolumn{5}{|c|}{ Studies that failed to show beneficial effects of low GI diets } \\
\hline $\begin{array}{l}\text { Frost, et al }{ }^{106} \\
\text { Eur J Clin Nutr, } \\
2004\end{array}$ & $\begin{array}{l}\text { RCT (parallel } \\
\text { design) }\end{array}$ & $\begin{array}{l}55 \text { patients with } \\
\text { CHD }\end{array}$ & 12 wks & $\begin{array}{l}\text { Lowering dietary GI did not cause } \\
\text { any significant improvement in } \\
\text { fasting glucose, insulin, TC, HDL, } \\
\text { VLDL, LDL and TG. }\end{array}$ \\
\hline $\begin{array}{l}\text { Oh, et al }{ }^{85} \\
\text { AM J Epidemiol, } \\
2005\end{array}$ & $\begin{array}{l}\text { Prospective } \\
\text { cohort study }\end{array}$ & $\begin{array}{l}78779 \text { US female } \\
\text { nurses }\end{array}$ & 18 yrs & $\begin{array}{l}\text { Neither GL nor GI was significantly } \\
\text { associated with the incidence of } \\
\text { total stroke or specific subtypes of } \\
\text { stoke. }\end{array}$ \\
\hline $\begin{array}{l}\text { van Dam, et al }{ }^{58} \\
\text { Eur J Clin Nutr, } \\
2000\end{array}$ & $\begin{array}{l}\text { Prospective } \\
\text { cohort study }\end{array}$ & 646 Dutch men & $10 \mathrm{yrs}$ & $\begin{array}{l}\text { GI was not appreciably associated } \\
\text { with } C H D \text { incidence }(R R=1.11) \text { and } \\
\text { TC, HDL, TG, insulin and glucose } \\
\text { levels. }\end{array}$ \\
\hline $\begin{array}{l}\text { Tavani, et al }{ }^{107} \\
\text { Heart, } 2003\end{array}$ & $\begin{array}{l}\text { Case-control } \\
\text { Study }\end{array}$ & \multicolumn{2}{|l|}{$\begin{array}{l}433 \text { MI cases } \\
\text { and } 448 \text { controls } \\
\text { in Italy }\end{array}$} & $\begin{array}{l}\text { GI was not statistically significantly } \\
\text { associated with MI }(\mathrm{OR}=1.38) \text {. }\end{array}$ \\
\hline \multicolumn{5}{|c|}{$\begin{array}{l}\text { * Ordered by study design and publication year (most recent first) } \\
\text { apoB: Apolipoprotein B, CHD: Coronary heart disease, CHO: Carbohydrate, CRP: C-reactive protein, GI: } \\
\text { Glycemic index, GL: Glycemic load, HDL: High density lipoprotein cholesterol, HOMA-IR: Insulin resistance } \\
\text { from homeostasis model assessment, LDL: Low density lipoprotein cholesterol, MI: Myocardial infarction, OR: } \\
\text { Odds ratio, PAI-1: Plasminogen activator inhibitor 1, RCT: Randomized controlled trial, RR: Relative risk, TC: } \\
\text { Total cholesterol, TG: Triglycerides, VLDL: Very low density lipoprotein cholesterol. }\end{array}$} \\
\hline
\end{tabular}

by Dickinson et al., the low quality of the GI database used in these kinds of observational studies is the most important contributor of the errors and biases towards the null hypothesis. ${ }^{25}$ The preliminary results of an ongoing study on the inter-method variation in GI values calculated by different persons shows that the outcome general GI values vary dramatically even though the same international 
table of glycemic index and glycemic load was used. ${ }^{10}$ In addition to this, we have some concern about the plausibility of basing the interpretation of findings merely on p-values. For example, in a study conducted by Tavani et al., the authors concluded that "high glycemic load and glycaemic index were not strongly associated with acute myocardial infarction risk" but in fact the Odds Ratios (OR) are 1.35 (95\% confidence interval: $0.93,1.98)$ and 1.38 (95\% CI: 0.95, 2.00), respectively for the middle and highest tertiles compared to the lowest tertile of GI, ${ }^{107}$ which might be clinically relevant.

\section{Glycemic index and cancer}

Cancer is now an increasingly important factor in the global burden of disease and, according to the $\mathrm{WHO}$, dietary factors are estimated to account for approximately $30 \%$ of cancers in the western world. In recent years, a substantial amount of studies have been conducted to link dietary GI to the risks of several types of cancer, including breast, colorectal, ovarian, endometrial, prostate, pancreatic, and gastric cancer. ${ }^{108-115}$ Although the underlying mechanisms are slightly different for different types of cancer, the insulin-like growth factor (IGF) system has been recognized as the mediator of the association between dietary GI and cancer risks. ${ }^{116}$ In both animal and human studies, insulin has been found to down regulate the levels of IGF binding proteins, thereby increase the bioactivity of IGF-1. A growing body of epidemiological data suggest that a high level of circulating IGF-1 is a risk factor for breast, prostate, colorectal and other types of cancer. ${ }^{117}$ However, results on the effects of foods with diverse GI levels on cancer risks are not in a complete agreement. For example, in one prospective study, the consumption of high GI was found to be associated with an increased risk of breast cancer among postmenopausal women (hazard ratio $(\mathrm{HR})=1.87,95 \% \mathrm{CI}: 1.18,2.97) .118$ This association, however, was not so marked in other studies. ${ }^{108,119,120}$ Therefore, further studies in this area are needed to clarify this issue.

\section{Glycemic index and disease-specific mortality}

So far, there are no data showing a reduction in mortality resulting from habitual low GI diets. However, it has been reported that hyperglycemia is a risk factor for subsequent cardiovascular disease mortality in diabetics and non-diabetics. ${ }^{25,}$, 21,122 This implies that focusing on the reduction of dietary GI may be relevant to decrease mortality, particularly mortality from cardiovascular disease, given the impacts of dietary GI on postprandial glycemic levels. Indirectly, similar conclusions could be drawn from the comparison of mortality rates in different countries. For example, according to the $\mathrm{WHO}$, the age-standardized death rates from diabetes, cardiovascular disease and malignant neoplasms are much lower in Japan compared to those in the UK and USA (see http://www.who.int/healthinfo/en/). Besides other potential factors, such as genetic susceptibility, which may have undeniable impacts on disease-specific mortality, habitual low GI eating patterns might also have a role 
in this. This hypothesis is based on the observation that the general GI levels of Japanese and Chinese diets may be lower than typical western meals because east Asian diets are rice based (which has a relatively lower GI than potatoes) and rich in vegetables and legumes. ${ }^{123,}{ }^{124}$ Additionally, plenty of evidence indicates that the Mediterranean diet represents a healthy eating pattern associated with lower allcause mortality and mortality from coronary heart disease and cancer. ${ }^{125,}{ }^{126}$ Although not exactly the same, the Mediterranean diet is essentially a low GI diet because it is pasta, instead of potato or bread, based and rich in grains (especially whole grains), fruits, nuts and vegetables. ${ }^{43,127}$

\section{Conclusions}

Despite the lack of consensus, the use of the GI has grown over the years and appears to have withstood the test of time. GI might be a complex term from a food science perspective but its public health application can be simple. For example, in Australia, people are instructed to: 1) replace higher GI foods with lower GI foods, choosing porridge or muesli instead of corn flakes, wholegrain bread instead of whole-meal or white bread and basmati or doongara rice instead of jasmine rice; 2) consume at least one serve of a lower GI CHO food at each meal; 3) look for foods with the GI symbol when selecting $\mathrm{CHO}$ foods at the supermarket. Meanwhile, promoting the consumption of low GI foods in clinical and public settings at least does not seem to have any foreseen adverse effects on human health. Choosing a high CHO low GI diet may help to "fine-tune" the glycemic control. This is also acknowledged by GI opponents. ${ }^{128}$

However, we must bear in mind that low GI foods are not necessarily healthier. Foods high in fat or sugar may have lower GI values than some healthy foods. Fructose has a low GI value but over- consumption of added fructose may elevate blood triglycerides level and contribute to insulin resistance. So, it may be imprudent to base food choices solely on GI values. Our recommendations are that the application of the GI should be in the context of the overall nutrient composition of the diet, focusing on the quality of starchy foods in particular while other dietary factors, such as energy density and contents of fiber and antioxidant should also be taken into account.

\section{Acknowledgement}

We acknowledge the contribution of Prof. Thomas M.S. Wolever from Department of Nutritional Sciences, University of Toronto, Canada.

\section{References}

1. Gray J. Carbohydrates: Nutritional and Health Aspects. ILSI Europe Concise Monographs. 2003.

2. Ludwig DS. The glycemic index: physiological mechanisms relating to obesity, diabetes, and cardiovascular disease. Jama. 2002;287(18):2414-2423. 
3. Jenkins DJ, Wolever TM, Taylor RH, et al. Glycemic index of foods: a physiological basis for carbohydrate exchange. Am J Clin Nutr. 1981;34(3):362-366.

4. FAO/WHO. Cabohydrates in Human Nutrition. A summary of the Joint FAO/WHO Expert Consultation. Rome.

5. Bornet FR, Billaux MS, Messing B. Glycaemic index concept and metabolic diseases. Int J Biol Macromol. 1997;21(1-2):207-219.

6. Lerer-Metzger M, Rizkalla SW, Luo J, et al. Effects of long-term low-glycaemic index starchy food on plasma glucose and lipid concentrations and adipose tissue cellularity in normal and diabetic rats. $\mathrm{Br}$ J Nutr. 1996;75(5):723-732.

7. Bouche C, Rizkalla SW, Luo J, et al. Five-week, low-glycemic index diet decreases total fat mass and improves plasma lipid profile in moderately overweight nondiabetic men. Diabetes Care. 2002;25(5):822-828.

8. Wolever TM, Bolognesi C. Prediction of glucose and insulin responses of normal subjects after consuming mixed meals varying in energy, protein, fat, carbohydrate and glycemic index. J Nutr. 1996;126(11):2807-2812.

9. Salmeron J, Manson JE, Stampfer MJ, et al. Dietary fiber, glycemic load, and risk of non-insulindependent diabetes mellitus in women. Jama. 1997;277(6):472-477.

10. Foster-Powell K, Holt SH, Brand-Miller JC. International table of glycemic index and glycemic load values: 2002. Am J Clin Nutr. 2002;76(1):5-56.

11. Sheard NF, Clark NG, Brand-Miller JC, et al. Dietary carbohydrate (amount and type) in the prevention and management of diabetes: a statement by the american diabetes association. Diabetes Care. 2004;27(9):2266-2271.

12. The U.S. Department of Health and Human Services (HHS) and the U.S. Department of Agriculture (USDA). Dietary Guidelines for Americans 2005

13. Ludwig DS, Majzoub JA, Al-Zahrani A, et al. High glycemic index foods, overeating, and obesity. Pediatrics. 1999;103(3):E26.

14. Thompson LU, Yoon JH, Jenkins DJ, et al. Relationship between polyphenol intake and blood glucose response of normal and diabetic individuals. Am J Clin Nutr. 1984;39(5):745-751.

15. Yoon JH, Thompson LU, Jenkins DJ. The effect of phytic acid on in vitro rate of starch digestibility and blood glucose response. Am J Clin Nutr. 1983;38(6):835-842.

16. Jenkins DJ, Kendall CW, Augustin LS, et al. Glycemic index: overview of implications in health and disease. Am J Clin Nutr. 2002;76(1):266S-273S.

17. Pi-Sunyer FX. Glycemic index and disease. Am J Clin Nutr. 2002;76(1):290S-298S.

18. Mani UV, Pradhan SN, Mehta NC, et al. Glycaemic index of conventional carbohydrate meals. $\mathrm{Br} J$ Nutr. 1992;68(2):445-450.

19. Henry CJ, Lightowler HJ, Strik CM, et al. Glycaemic index values for commercially available potatoes in Great Britain. Br J Nutr. 2005;94(6):917-921.

20. Flint A, Moller BK, Raben A, et al. The use of glycaemic index tables to predict glycaemic index of composite breakfast meals. Br J Nutr. 2004;91(6):979-989.

21. Coulston AM, Hollenbeck CB, Swislocki AL, et al. Effect of source of dietary carbohydrate on plasma glucose and insulin responses to mixed meals in subjects with NIDDM. Diabetes Care. 1987;10(4):395400 .

22. Alfenas RC, Mattes RD. Influence of glycemic index/load on glycemic response, appetite, and food intake in healthy humans. Diabetes Care. 2005;28(9):2123-2129.

23. Chew I, Brand JC, Thorburn AW, et al. Application of glycemic index to mixed meals. Am J Clin Nutr. 1988;47(1):53-56.

24. Wolever TM, Jenkins DJ. The use of the glycemic index in predicting the blood glucose response to mixed meals. Am J Clin Nutr. 1986;43(1):167-172.

25. Dickinson S, Brand-Miller J. Glycemic index, postprandial glycemia and cardiovascular disease. Curr Opin Lipidol. 2005;16(1):69-75.

26. Wolever TM, Jenkins DJ, Jenkins $\mathrm{AL}$, et al. The glycemic index: methodology and clinical implications. Am J Clin Nutr. 1991;54(5):846-854. 
27. Brouns F, Bjorck, I, Frayn, KN , and Wolever, TMS. Glycaemic index methodology. Nutrition Research Reviews. 2005;18:145-171.

28. Porth C. Pathophysiology: Concepts of Altered Health States, 7th Edition, Chapter 7: Diabetes: Lippincott Williams \& Wilkins ISBN: 0-7817-4988-3.

29. Fontvieille AM, Rizkalla SW, Penfornis A, et al. The use of low glycaemic index foods improves metabolic control of diabetic patients over five weeks. Diabet Med. 1992;9(5):444-450.

30. Giacco R, Parillo M, Rivellese AA, et al. Long-term dietary treatment with increased amounts of fiber-rich low-glycemic index natural foods improves blood glucose control and reduces the number of hypoglycemic events in type 1 diabetic patients. Diabetes Care. 2000;23(10):1461-1466.

31. Gilbertson HR, Brand-Miller JC, Thorburn AW, et al. The effect of flexible low glycemic index dietary advice versus measured carbohydrate exchange diets on glycemic control in children with type 1 diabetes. Diabetes Care. 2001;24(7):1137-1143.

32. Brand JC, Colagiuri S, Crossman S, et al. Low-glycemic index foods improve long-term glycemic control in NIDDM. Diabetes Care. 1991;14(2):95-101.

33. Brand-Miller J, Hayne S, Petocz P, et al. Low-glycemic index diets in the management of diabetes: a meta-analysis of randomized controlled trials. Diabetes Care. 2003;26(8):2261-2267.

34. Opperman AM, Venter CS, Oosthuizen W, et al. Meta-analysis of the health effects of using the glycaemic index in meal-planning. Br J Nutr. 2004;92(3):367-381.

35. Moore MC, Davis SN, Mann SL, et al. Acute fructose administration improves oral glucose tolerance in adults with type 2 diabetes. Diabetes Care. 2001;24(11):1882-1887.

36. Koivisto VA, Yki-Jarvinen H. Fructose and insulin sensitivity in patients with type 2 diabetes. J Intern Med. 1993;233(2):145-153.

37. Osei K, Bossetti B. Dietary fructose as a natural sweetener in poorly controlled type 2 diabetes: a 12month crossover study of effects on glucose, lipoprotein and apolipoprotein metabolism. Diabet Med. 1989;6(6):506-511.

38. Pelkonen R, Aro A, Nikkila EA. Metabolic effects of dietary fructose in insulin dependent diabetes of adults. Acta Med Scand Suppl. 1972;542:187-193.

39. Rizkalla SW, Taghrid L, Laromiguiere M, et al. Improved plasma glucose control, whole-body glucose utilization, and lipid profile on a low-glycemic index diet in type 2 diabetic men: a randomized controlled trial. Diabetes Care. 2004;27(8):1866-1872.

40. Jimenez-Cruz A, Bacardi-Gascon M, Turnbull WH, et al. A flexible, low-glycemic index mexicanstyle diet in overweight and obese subjects with type 2 diabetes improves metabolic parameters during a 6-week treatment period. Diabetes Care. 2003;26(7):1967-1970.

41. Jarvi AE, Karlstrom BE, Granfeldt $\mathrm{YE}$, et al. Improved glycemic control and lipid profile and normalized fibrinolytic activity on a low-glycemic index diet in type 2 diabetic patients. Diabetes Care. 1999;22(1):10-18.

42. Qi L, Rimm E, Liu S, et al. Dietary glycemic index, glycemic load, cereal fiber, and plasma adiponectin concentration in diabetic men. Diabetes Care. 2005;28(5):1022-1028.

43. Buyken AE, Toeller M, Heitkamp G, et al. Glycemic index in the diet of European outpatients with type 1 diabetes: relations to glycated hemoglobin and serum lipids. Am J Clin Nutr. 2001;73(3):574-581.

44. Calle-Pascual AL, Gomez V, Leon E, et al. Foods with a low glycemic index do not improve glycemic control of both type 1 and type 2 diabetic patients after one month of therapy. Diabete Metab. 1988;14(5):629-633.

45. Stratton IM, Adler AI, Neil HA, et al. Association of glycaemia with macrovascular and microvascular complications of type 2 diabetes (UKPDS 35): prospective observational study. Bmj. 2000;321(7258):405-412.

46. Mann JI. The role of nutritional modifications in the prevention of macrovascular complications of diabetes. Diabetes. 1997;46 Suppl 2:S125-130.

47. Laaksonen DE, Toppinen LK, Juntunen KS, et al. Dietary carbohydrate modification enhances insulin secretion in persons with the metabolic syndrome. Am J Clin Nutr. 2005;82(6):1218-1227. 
48. Brynes AE, Mark Edwards C, Ghatei MA, et al. A randomised four-intervention crossover study investigating the effect of carbohydrates on daytime profiles of insulin, glucose, non-esterified fatty acids and triacylglycerols in middle-aged men. Br J Nutr. 2003;89(2):207-218.

49. Wolever TM, Mehling C. Long-term effect of varying the source or amount of dietary carbohydrate on postprandial plasma glucose, insulin, triacylglycerol, and free fatty acid concentrations in subjects with impaired glucose tolerance. Am J Clin Nutr. 2003;77(3):612-621.

50. Seewi G, Gnauck G, Stute R, et al. Effects on parameters of glucose homeostasis in healthy humans from ingestion of leguminous versus maize starches. Eur J Nutr. 1999;38(4):183-189.

51. Slabber M, Barnard HC, Kuyl JM, et al. Effects of a low-insulin-response, energy-restricted diet on weight loss and plasma insulin concentrations in hyperinsulinemic obese females. Am J Clin Nutr. 1994;60(1):48-53.

52. Schulze MB, Liu S, Rimm EB, et al. Glycemic index, glycemic load, and dietary fiber intake and incidence of type 2 diabetes in younger and middle-aged women. Am J Clin Nutr. 2004;80(2):348-356.

53. Hodge AM, English DR, O'Dea K, et al. Glycemic index and dietary fiber and the risk of type 2 diabetes. Diabetes Care. 2004;27(11):2701-2706.

54. Salmeron J, Ascherio A, Rimm EB, et al. Dietary fiber, glycemic load, and risk of NIDDM in men. Diabetes Care. 1997;20(4):545-550.

55. McKeown NM, Meigs JB, Liu S, et al. Carbohydrate nutrition, insulin resistance, and the prevalence of the metabolic syndrome in the Framingham Offspring Cohort. Diabetes Care. 2004;27(2):538-546.

56. Stevens J, Ahn K, Juhaeri, et al. Dietary fiber intake and glycemic index and incidence of diabetes in African-American and white adults: the ARIC study. Diabetes Care. 2002;25(10):1715-1721.

57. Meyer KA, Kushi LH, Jacobs DR, Jr., et al. Carbohydrates, dietary fiber, and incident type 2 diabetes in older women. Am J Clin Nutr. 2000;71(4):921-930.

58. van Dam RM, Visscher AW, Feskens EJ, et al. Dietary glycemic index in relation to metabolic risk factors and incidence of coronary heart disease: the Zutphen Elderly Study. Eur J Clin Nutr. 2000;54(9):726-731.

59. Liese AD, Schulz M, Fang F, et al. Dietary glycemic index and glycemic load, carbohydrate and fiber intake, and measures of insulin sensitivity, secretion, and adiposity in the Insulin Resistance Atherosclerosis Study. Diabetes Care. 2005;28(12):2832-2838.

60. Lau C, Faerch K, Glumer C, et al. Dietary glycemic index, glycemic load, fiber, simple sugars, and insulin resistance: the Inter99 study. Diabetes Care. 2005;28(6):1397-1403.

61. Pawlak DB, Kushner JA, Ludwig DS. Effects of dietary glycaemic index on adiposity, glucose homoeostasis, and plasma lipids in animals. Lancet. 2004;364(9436):778-785.

62. Higgins JA, Brand Miller JC, Denyer GS. Development of insulin resistance in the rat is dependent on the rate of glucose absorption from the diet. J Nutr. 1996;126(3):596-602.

63. Byrnes SE, Miller JC, Denyer GS. Amylopectin starch promotes the development of insulin resistance in rats. J Nutr. 1995;125(6):1430-1437.

64. Vaughan L. Professional consensus statement----Suggested good practice for Dietitians involved in the dietetic management of adults, with type 1 diabetes, treated with insulin analogues: The Diabetes Management and Education group of the British Dietetic Association; March, 2005.

65. Connor H, Annan F, Bunn E, et al. The implementation of nutritional advice for people with diabetes. Diabet Med. 2003;20(10):786-807.

66. Ha TK, Lean ME. Recommendations for the nutritional management of patients with diabetes mellitus. Eur J Clin Nutr. 1998;52(7):467-481.

67. Wolever T, Barbeau M-C, Charron S, et al. Guidelines for the Nutritional Management of Diabetes Mellitus in the New Millennium: A position Statement by the Canadian Diabetes Association. 1999.

68. Spieth LE, Harnish JD, Lenders CM, et al. A low-glycemic index diet in the treatment of pediatric obesity. Arch Pediatr Adolesc Med. 2000;154(9):947-951.

69. Bahadori B, Yazdani-Biuki B, Krippl P, et al. Low-fat, high-carbohydrate (low-glycaemic index) diet induces weight loss and preserves lean body mass in obese healthy subjects: results of a 24-week study. Diabetes Obes Metab. 2005;7(3):290-293. 
70. Toeller M, Buyken AE, Heitkamp G, et al. Nutrient intakes as predictors of body weight in European people with type 1 diabetes. Int J Obes Relat Metab Disord. 2001;25(12):1815-1822.

71. Raatz SK, Torkelson CJ, Redmon JB, et al. Reduced glycemic index and glycemic load diets do not increase the effects of energy restriction on weight loss and insulin sensitivity in obese men and women. J Nutr. 2005;135(10):2387-2391.

72. Carels RA, Darby LA, Douglass OM, et al. Education on the glycemic index of foods fails to improve treatment outcomes in a behavioral weight loss program. Eat Behav. 2005;6(2):145-150.

73. Sloth B, Krog-Mikkelsen I, Flint A, et al. No difference in body weight decrease between a lowglycemic-index and a high-glycemic-index diet but reduced LDL cholesterol after 10-wk ad libitum intake of the low-glycemic-index diet. Am J Clin Nutr. 2004;80(2):337-347.

74. Wolever TM, Jenkins DJ, Vuksan V, et al. Beneficial effect of low-glycemic index diet in overweight NIDDM subjects. Diabetes Care. 1992;15(4):562-564.

75. Jenkins DJ, Wolever TM, Buckley G, et al. Low-glycemic-index starchy foods in the diabetic diet. Am J Clin Nutr. 1988;48(2):248-254.

76. Caterson ID, Hubbard V, Bray GA, et al. Prevention Conference VII: Obesity, a worldwide epidemic related to heart disease and stroke: Group III: worldwide comorbidities of obesity. Circulation. 2004;110(18):e476-483.

77. Brand-Miller JC, Holt SH, Pawlak DB, et al. Glycemic index and obesity. Am J Clin Nutr. 2002;76(1):281S-285S.

78. Ludwig DS. Dietary glycemic index and the regulation of body weight. Lipids. 2003;38(2):117-121.

79. Warren JM, Henry CJ, Simonite V. Low glycemic index breakfasts and reduced food intake in preadolescent children. Pediatrics. 2003;112(5):e414.

80. Jimenez-Cruz A, Gutierrez-Gonzalez AN, Bacardi-Gascon M. Low glycemic index lunch on satiety in overweight and obese people with type 2 diabetes. Nutr Hosp. 2005;20(5):348-350.

81. Ball SD, Keller KR, Moyer-Mileur LJ, et al. Prolongation of satiety after low versus moderately high glycemic index meals in obese adolescents. Pediatrics. 2003;111(3):488-494.

82. Kabir M, Guerre-Millo M, Laromiguiere $M$, et al. Negative regulation of leptin by chronic highglycemic index starch diet. Metabolism. 2000;49(6):764-769.

83. Pawlak DB, Bryson JM, Denyer GS, et al. High glycemic index starch promotes hypersecretion of insulin and higher body fat in rats without affecting insulin sensitivity. J Nutr. 2001;131(1):99-104.

84. Kabir M, Rizkalla SW, Champ M, et al. Dietary amylose-amylopectin starch content affects glucose and lipid metabolism in adipocytes of normal and diabetic rats. J Nutr. 1998;128(1):35-43.

85. Oh K, Hu FB, Cho E, et al. Carbohydrate intake, glycemic index, glycemic load, and dietary fiber in relation to risk of stroke in women. Am J Epidemiol. 2005;161(2):161-169.

86. Liu S, Willett WC, Stampfer MJ, et al. A prospective study of dietary glycemic load, carbohydrate intake, and risk of coronary heart disease in US women. Am J Clin Nutr. 2000;71(6):1455-1461.

87. Glucose tolerance and mortality: comparison of WHO and American Diabetes Association diagnostic criteria. The DECODE study group. European Diabetes Epidemiology Group. Diabetes Epidemiology: Collaborative analysis Of Diagnostic criteria in Europe. Lancet. 1999;354(9179):617-621.

88. Liu S, Manson JE, Buring JE, et al. Relation between a diet with a high glycemic load and plasma concentrations of high-sensitivity C-reactive protein in middle-aged women. Am J Clin Nutr. 2002;75(3):492-498.

89. Reaven GM. Banting lecture 1988. Role of insulin resistance in human disease. Diabetes. 1988;37(12):1595-1607.

90. Juan CC, Fang VS, Kwok CF, et al. Exogenous hyperinsulinemia causes insulin resistance, hyperendothelinemia, and subsequent hypertension in rats. Metabolism. 1999;48(4):465-471.

91. Despres JP, Lamarche B, Mauriege $\mathrm{P}$, et al. Hyperinsulinemia as an independent risk factor for ischemic heart disease. N Engl J Med. 1996;334(15):952-957.

92. Westerbacka J, Yki-Jarvinen H. Arterial stiffness and insulin resistance. Semin Vasc Med. 2002;2(2):157164. 
93. Kabir M, Rizkalla SW, Quignard-Boulange A, et al. A high glycemic index starch diet affects lipid storage-related enzymes in normal and to a lesser extent in diabetic rats. J Nutr. 1998;128(11):18781883.

94. Brand-Miller JC. Glycemic index in relation to coronary disease. Asia Pac J Clin Nutr. 2004;13(Suppl):S3.

95. Jenkins DJ, Wolever TM, Kalmusky J, et al. Low-glycemic index diet in hyperlipidemia: use of traditional starchy foods. Am J Clin Nutr. 1987;46(1):66-71.

96. Frost G, Leeds AA, Dore CJ, et al. Glycaemic index as a determinant of serum HDL-cholesterol concentration. Lancet. 1999;353(9158):1045-1048.

97. Pereira MA, Swain J, Goldfine $A B$, et al. Effects of a low-glycemic load diet on resting energy expenditure and heart disease risk factors during weight loss. Jama. 2004;292(20):2482-2490.

98. Ebbeling $\mathrm{CB}$, Leidig $\mathrm{MM}$, Sinclair $\mathrm{KB}$, et al. Effects of an ad libitum low-glycemic load diet on cardiovascular disease risk factors in obese young adults. Am J Clin Nutr. 2005;81(5):976-982.

99. Harbis A, Perdreau S, Vincent-Baudry S, et al. Glycemic and insulinemic meal responses modulate postprandial hepatic and intestinal lipoprotein accumulation in obese, insulin-resistant subjects. Am J Clin Nutr. 2004;80(4):896-902.

100. Patel VC, Aldridge RD, Leeds A, et al. Retrospective analysis of the impact of a low glycaemic index diet on hospital stay following coronary artery bypass grafting: a hypothesis. J Hum Nutr Diet. 2004;17(3):241-247.

101. Dumesnil JG, Turgeon J, Tremblay A, et al. Effect of a low-glycaemic index--low-fat--high protein diet on the atherogenic metabolic risk profile of abdominally obese men. Br J Nutr. 2001;86(5):557-568.

102. Frost $G$, Leeds $A$, Trew $G$, et al. Insulin sensitivity in women at risk of coronary heart disease and the effect of a low glycemic diet. Metabolism. 1998;47(10):1245-1251.

103. Sciarrone SE, Strahan MT, Beilin LJ, et al. Ambulatory blood pressure and heart rate responses to vegetarian meals. J Hypertens. 1993;11(3):277-285.

104. Brynes AE, Adamson J, Dornhorst A, et al. The beneficial effect of a diet with low glycaemic index on $24 \mathrm{~h}$ glucose profiles in healthy young people as assessed by continuous glucose monitoring. $\mathrm{Br} \mathrm{J}$ Nutr. 2005;93(2):179-182.

105. Ford ES, Liu S. Glycemic index and serum high-density lipoprotein cholesterol concentration among us adults. Arch Intern Med. 2001;161(4):572-576.

106. Frost GS, Brynes AE, Bovill-Taylor C, et al. A prospective randomised trial to determine the efficacy of a low glycaemic index diet given in addition to healthy eating and weight loss advice in patients with coronary heart disease. Eur J Clin Nutr. 2004;58(1):121-127.

107. Tavani A, Bosetti C, Negri E, et al. Carbohydrates, dietary glycaemic load and glycaemic index, and risk of acute myocardial infarction. Heart. 2003;89(7):722-726.

108. Giles GG, Simpson JA, English DR, et al. Dietary carbohydrate, fibre, glycaemic index, glycaemic load and the risk of postmenopausal breast cancer. Int J Cancer. 2005.

109. Levi F, Pasche C, Lucchini F, et al. Glycaemic index, breast and colorectal cancer. Ann Oncol. 2002;13(10):1688-1689.

110. Augustin LS, Galeone C, Dal Maso L, et al. Glycemic index, glycemic load and risk of prostate cancer. Int J Cancer. 2004;112(3):446-450.

111. Augustin LS, Gallus S, Negri E, et al. Glycemic index, glycemic load and risk of gastric cancer. Ann Oncol. 2004;15(4):581-584.

112. Folsom AR, Demissie Z, Harnack L. Glycemic index, glycemic load, and incidence of endometrial cancer: the Iowa women's health study. Nutr Cancer. 2003;46(2):119-124.

113. Michaud DS, Liu S, Giovannucci E, et al. Dietary sugar, glycemic load, and pancreatic cancer risk in a prospective study. J Natl Cancer Inst. 2002;94(17):1293-1300.

114. Terry PD, Jain M, Miller AB, et al. Glycemic load, carbohydrate intake, and risk of colorectal cancer in women: a prospective cohort study. J Natl Cancer Inst. 2003;95(12):914-916.

115. Augustin LS, Polesel J, Bosetti C, et al. Dietary glycemic index, glycemic load and ovarian cancer risk: a case-control study in Italy. Ann Oncol. 2003;14(1):78-84. 
116. Brand-Miller JC, Liu V, Petocz P, et al. The glycemic index of foods influences postprandial insulinlike growth factor-binding protein responses in lean young subjects. Am J Clin Nutr. 2005;82(2):350354 .

117. LeRoith D, Roberts CT, Jr. The insulin-like growth factor system and cancer. Cancer Lett. 2003;195(2):127-137.

118. Silvera SA, Jain M, Howe GR, et al. Dietary carbohydrates and breast cancer risk: a prospective study of the roles of overall glycemic index and glycemic load. Int J Cancer. 2005;114(4):653-658.

119. Holmes MD, Liu S, Hankinson SE, et al. Dietary carbohydrates, fiber, and breast cancer risk. Am J Epidemiol. 2004;159(8):732-739.

120. Higginbotham S, Zhang ZF, Lee IM, et al. Dietary glycemic load and breast cancer risk in the Women's Health Study. Cancer Epidemiol Biomarkers Prev. 2004;13(1):65-70.

121. Ceriello A. Acute hyperglycaemia: a 'new' risk factor during myocardial infarction. Eur Heart J. 2005;26(4):328-331.

122. Andersson DK, Svardsudd K. Long-term glycemic control relates to mortality in type II diabetes. Diabetes Care. 1995;18(12):1534-1543.

123. Sugiyama M, Tang AC, Wakaki $Y$, et al. Glycemic index of single and mixed meal foods among common Japanese foods with white rice as a reference food. Eur J Clin Nutr. 2003;57(6):743-752.

124. Woo J, Ho SC, Sham A, et al. Diet and glucose tolerance in a Chinese population. Eur J Clin Nutr. 2003;57(4):523-530.

125. Hu FB. The Mediterranean diet and mortality--olive oil and beyond. N Engl J Med. 2003;348(26):25952596.

126. Knoops KT, de Groot LC, Kromhout D, et al. Mediterranean diet, lifestyle factors, and 10-year mortality in elderly European men and women: the HALE project. Jama. 2004;292(12):1433-1439.

127. Riccardi G, Clemente G, Giacco R. Glycemic index of local foods and diets: the Mediterranean experience. Nutr Rev. 2003;61(5 Pt 2):S56-60.

128. Franz MJ. The glycemic index: not the most effective nutrition therapy intervention. Diabetes Care. 2003;26(8):2466-2468. 


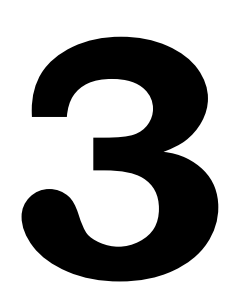

\title{
Glycemic index and glycemic load in relation to food and nutrient intake and metabolic risk factors in a Dutch population
}

\author{
H. Du, D. L. van der A, M. M.E. van Bakel, C. J. van der Kallen, \\ E. E. Blaak, M. M. van Greevenbroek, E. H. Jansen, G. Nijpels, \\ C.D. Stehouwer, J. M. Dekker, E. J.M. Feskens.
}

Am J Clin Nutr. 2008;87(3):655-661.

\begin{abstract}
Background: Previous studies on the glycemic index (GI) and glycemic load (GL) have shown inconsistent findings on their association with metabolic risk factors. This may be partly due to differences in underlying dietary patterns.

Objective: To examine the association of GI and GL with food and nutrient intake, and metabolic risk factors including blood glucose, insulin, lipids and high sensitivity C-reactive protein (CRP).

Design: Cross-sectional analyses of data from two joint observational studies, the CoDAM study and the Hoorn study.

Results: In total 974 subjects aged 42 - 87 yrs were included in this study. Mean (SD) GI was 57 (4) and mean GL was 130 (39). Dairy products, potatoes and other tubers, cereal products, and fruits were the main predictive food groups for GI. GL was closely correlated with intake of total carbohydrates $\left(r_{s}=0.97\right)$, which explained more than $95 \%$ of the variation in GL. After adjusting for potential confounders, GI was significantly inversely associated with HDL-C and positively associated with fasting insulin, HOMA-index of insulin resistance, total to HDL-C cholesterol ratio and CRP. No association was observed between GL and any of the metabolic risk factors, except for a borderline significant positive association with CRP.

Conclusions: In this population, a low GI diet, which is high in dairy and fruits but low in potatoes and cereals, is associated with improved insulin sensitivity and lipid metabolism and reduced chronic inflammation. GL is highly correlated with carbohydrate intake and is not clearly associated with the investigated metabolic risk factors.

Key words: Glycemic index (GI); Glycemic load (GL); Metabolic risk factor; Glycemic control; Insulin Resistance; Lipid metabolism; Systematic chronic inflammation.
\end{abstract}




\section{Introduction}

The glycemic index (GI), an indicator ranking carbohydrates according to their impacts on body's postprandial glycemic response, was introduced more than two decades ago to facilitate glycemic control in patients with diabetes. ${ }^{1}$ It was described as the percentage of incremental area under the 2-hour blood glucose response curve of a test food divided by the corresponding area of a reference food containing same amount of available carbohydrates. The glycemic load (GL) was introduced more recently, as a product of GI with the amount of total available carbohydrates. ${ }^{2}$ Since then, research has been extended to the role of GI and GL in the prevention and management of overweight and obesity ${ }^{3}$ cardiovascular diseases (CVD) ${ }^{4}$ cancer, ${ }^{5}$ and many other health problems such as age-related macular degeneration. ${ }^{6}$ However, findings are not always consistent and consensus regarding the incorporation of the GI and GL concepts in dietary guidelines has not yet been reached.7,8

Liu et al. observed that GI and GL are inversely associated with the concentration of high-density lipoprotein cholesterol (HDL-C) and positively associated with triacylglycerol (TG) and high sensitivity C-reactive protein (CRP) concentrations in US women.9, 10 Frost et al. showed that GI is associated with serum HDL-C concentration in middle aged British men and women. ${ }^{11}$ These associations, however, were not detected by van Dam et al. in Dutch elderly men. ${ }^{12}$ In a Danish prospective study, Oxlund et al. found only weak associations between GI, GL and changes in serum lipids. ${ }^{13}$

Although GI and GL are based on the different influences of carbohydrates on glucose and insulin responses, findings from epidemiological studies on their associations with markers of glycemic control and insulin sensitivity are conflicting. ${ }^{14}$ For example, a positive association between GI and insulin resistance index was found in the Framingham Offspring Cohort, ${ }^{15}$ but not in the Insulin Resistance Atherosclerosis study. ${ }^{16}$ Evidence from observational studies and clinical trials supports the positive association between GI and $\mathrm{HbA} 1 \mathrm{c}$ in diabetic patients, ${ }^{17-19}$ but findings in general populations are contradictory. ${ }^{20,21}$

One of the practical concerns about whether a low GI diet should be recommended is that low GI or GL diets may limit food choices and increase fat intake. ${ }^{22}$ Therefore, understanding the relationship of GI and GL with food and nutrient intake is important. This may also provide further insight into the underlying reasons for the diverse findings in the associations between GI and GL and health-related outcomes.

Under the joint efforts of the EPIC (European Prospective Investigation into Cancer and Nutrition) and the DiOGenes study, an extensive GI database has recently been developed to be used to investigate the association of GI and GL with cancer, obesity and other health indicators. ${ }^{23}$ For European studies this incorporates the best knowledge in the field so far. Using this database, we conducted the current study to investigate the relationship of GI and GL with food and nutrient intake, and 
to explore their association with metabolic risk factors, including markers of glycemic control, insulin sensitivity, lipid metabolism and systematic chronic inflammation, in a combined population consisting of subjects from two ongoing observational studies in The Netherlands.

\section{Subjects and Methods \\ Subjects}

The study population included participants of the CoDAM study (Cohort study Diabetes and Atherosclerosis Maastricht) ${ }^{24}$ and subjects taking part in the follow-up examination of the Hoorn study. ${ }^{25}$ Supported by a common grant, both studies were carried out jointly and followed a same research protocol to investigate the behavioral and genetics associates of obesity, diabetes and atherosclerosis.

The CoDAM study started in 1999-2000 and is a population based cohort study designed to investigate the effects of glucose metabolism, blood lipids, lifestyle and genetic factors on CVD morbidity and mortality. ${ }^{24}$ Subjects were invited after a screening oral glucose tolerance test in a high-risk population based on the following inclusion criteria: Caucasian, 40 to 70 years old, not using medication that affects glucose metabolism, and either BMI $>25 \mathrm{~kg} / \mathrm{m}^{2}$, a family history of type 2 diabetes mellitus (T2DM), a history of gestational diabetes, use of antihypertensive medication, a postprandial blood glucose $>6.0 \mathrm{mmol} / \mathrm{l}$, or glucosuria. In total 574 subjects were recruited. The study protocol was approved by the Medical Ethical Review Committee of Maastricht University and written informed consent was obtained from all participants before the start of the study.

The Hoorn study, which started in 1989, is a population based cohort study investigating the glucose tolerance status and cardiovascular risk factors among a sample of the general population in Hoorn, the Netherlands. ${ }^{25}$ In 2000-2001, a followup examination was conducted in a selected group of 903 subjects consisting of all subjects with T2DM and a random sample of the survival cohort with normal or impaired glucose metabolism. Details of the study population have been described previously. ${ }^{26}$ The Ethical Review Committee of the VU University Medical Center Amsterdam approved the study and written informed consent was obtained from all participants prior to participation.

We excluded a priori subjects to whom any of the following applied: more than $10 \%$ missing items in the food-frequency questionnaire (FFQ), ratio of total energy intake over predicted resting energy expenditure in the top and bottom $1 \%$, implausible energy intake $(<800$ or $>4200 \mathrm{kcal} /$ day for men and $<500$ or $>3500$ $\mathrm{kcal} /$ day for women), self-reported diabetes, following a specific diet (i.e. weight-loss or cholesterol-lowering diet), and using cholesterol-lowering medication. The current study population consisted of 974 subjects, 517 men and 457 women, of whom 321 originated from the CoDAM study and 653 from the Hoorn study.

\section{Dietary assessments}


Both studies used the same validated FFQ to assess subjects' habitual dietary intake. This FFQ was developed for Dutch cohorts of the EPIC study and details of the FFQ have been described previously.27, 28 In brief, it is a self-administered quantitative FFQ. Its relative validity against multiple 24-hour recalls in terms of total energy, carbohydrates, fiber, breads, cereals and pasta, potatoes, fruits, dairy products, sugar and sweet products was relatively high (Spearman correlation coefficients $\left(\mathrm{r}_{\mathrm{s}}\right) 0.51-0.79$ ). Food items from the FFQ were collapsed into seventeen food groups following the same classification method applied by the EPIC study. ${ }^{29}$ Intakes of energy and nutrients were calculated according to the extended version of the Dutch food composition table (NEVO) 1996. ${ }^{30}$ Dietary GI and GL were calculated according to the formulas below:

$$
\mathrm{GI}=\sum_{i=1}^{n}\left(\mathrm{GI}_{i} \times \mathrm{CHO}_{i}\right) / \sum_{i=1}^{n} \mathrm{CHO}_{i} \quad \mathrm{GL}=\sum_{i=1}^{n}\left(\mathrm{GI}_{i} \times \mathrm{CHO}_{i}\right) / 100
$$

GI $i$ is the GI value of food $i$ from the GI database. The source of the GI values used to compile this GI database has been described before. ${ }^{23}$ In brief, published GI values ${ }^{31-33}$ derived from 50-gram glucose as the reference food and 2-hour testing periods. For generic items in the FFQ, the 24-hour dietary recall values were used to weigh the mean GI values based on the frequency of consumption. $\mathrm{CHO} i$ is the amount of available carbohydrates from food $i$ calculated by the amount of food consumed (g/day) multiplied by the carbohydrate content from NEVO $(\mathrm{g} / \mathrm{g})$, and $n$ is the number of foods eaten per day. In the current analysis, foods involved in calculating the GI and GL provided approximately $98 \%$ of the total available carbohydrate intake.

\section{Biochemical measurements}

During the first visit of subjects to the research units, venous blood samples were drawn from all participants after overnight $(>12 \mathrm{~h})$ fasting. Serum and plasma were immediately separated after centrifugation $\left(3000 \mathrm{rpm}\right.$ for $15 \mathrm{~min}$ at $4{ }^{\circ} \mathrm{C}$ ) and stored at $-70{ }^{\circ} \mathrm{C}$ until the assays were performed.

A standard 75g oral glucose tolerance test (OGTT) was performed. Fasting and 2hour postprandial plasma glucose concentrations were measured using enzymatic methods (G6PDase method, ABX Diagnostics Glucose HK 125, Montpellier, France for the CoDAM study; hexokinase method, Roche Diagnostics $\mathrm{GmbH}$, Mannheim, Germany for the Hoorn study). Glucose metabolic status was evaluated according to the WHO 1999 criteria. ${ }^{34} \mathrm{HbA} 1 \mathrm{c}$ was analyzed using ion-exchange high performance liquid chromatography (HPLC, Bio-Rad, Veenendaal, The Netherlands). Insulin was measured using a paired monoclonal antibody-based two-site immunoradiometric assay (Medgenix Diagnostics, Fleurus, Belgium). HOMA-IR (insulin resistance index of homeostatic model assessment) was calculated using a Microsoft Excel ${ }^{\circledR}$ based HOMA 2 calculator. ${ }^{35}$ Total cholesterol (TC), HDL-C and TG were measured using 
enzymatic techniques (Roche Diagnostics, Mannheim, Germany) and low-density lipoprotein cholesterol (LDL-C) was calculated using the Friedewald formula. ${ }^{36}$ High sensitivity CRP was measured in serum samples using a Hitachi-912 auto-analyzer (Roche Diagnostics, Mannheim, Germany) in the CoDAM study, and in EDTAplasma samples using a high sensitive in-house sandwich enzyme immunoassay (Dako, Copenhagen, Denmark and Sigma Chemical Co., St. Louis, USA) in the Hoorn study. All measurements have inter- and intra- assay coefficients of variation (CVs) lower than $8 \%$.

\section{Anthropometric and other measurements}

A self-administered questionnaire was used to collect information on demographic characteristics, lifestyle habits and health and disease status. The validated SQUASH (Short QUestionnaire to ASsess Health-enhancing physical activity) questionnaire was used to measure physical activity levels. ${ }^{37}$

At the time of research unit visit, body weight, height and waist circumference were measured without shoes and in light clothing to the nearest 100 gram and $1 \mathrm{~cm}$ respectively. Body mass index (BMI, $\mathrm{kg} / \mathrm{m}^{2}$ ) was calculated as weight divided by height squared.

\section{Statistical methods}

Stepwise regression analyses were carried out to investigate the contribution of food groups to the inter-individual variation in GI and GL. For those food groups contributing at least $1 \%$ variation, multiple linear regression analyses were performed with only those predictive food groups plus total energy as explanatory variables, and GI or GL as the response variable. Associations of energy, macronutrients and their components with GI and GL were investigated through Spearman correlation analyses with and without the adjustment for total energy intake.

Metabolic risk factors were log-transformed to improve their distribution towards normal. Multiple linear regression analyses were performed to explore the associations of GI and GL with the metabolic risk factors. These analyses were adjusted for potential confounders including age, gender, current smoking status (yes or no), physical activity (inactive, moderately active, highly active and unknown), cohort (CoDAM or Hoorn) and the intake of total energy, alcohol, fiber, cholesterol, animal- and plant-based protein and saturated fatty acids (SFA). For GI, we additionally adjusted for monounsaturated fatty acids (MUFA), polyunsaturated fatty acids (PUFA), polysaccharides and mono- and disaccharides. Total energy intake was adjusted for by using the residual method. 38

Interaction of GI and GL with age, gender, smoking, physical activity and cohort was explored by adding interaction terms to the models. In none of the analyses the interaction term with cohort reached statistical significance, indicating that pooling of the data was justified. All analyses were performed using the SAS statistical 
software package (version 9.1; SAS Institute Inc, Cary, NC, USA). $P<0.05$ was considered significant.

\begin{tabular}{|c|c|c|c|c|}
\hline \multicolumn{5}{|c|}{ Table 3-1. Population characteristics by study $(\mathrm{n}=974)$. } \\
\hline & $\begin{array}{c}\text { Total } \\
(\mathrm{n}=974)\end{array}$ & $\begin{array}{l}\text { CoDAM } \\
(\mathrm{n}=321)\end{array}$ & $\begin{array}{c}\text { Hoorn } \\
(\mathrm{n}=653)\end{array}$ & $P$ value $*$ \\
\hline Age $^{+}$, years & $65 \pm 9$ & $58 \pm 7$ & $68 \pm 7$ & $<0.0001$ \\
\hline Gender, $\mathrm{n}(\%)$ of men & $517(53)$ & $192(60)$ & $325(50)$ & 0.003 \\
\hline Glycemic index & $57 \pm 4$ & $59 \pm 3$ & $56 \pm 3$ & $<0.0001$ \\
\hline Glycemic load ${ }^{+} \neq$ & $130 \pm 39$ & $143 \pm 41$ & $123 \pm 36$ & $<0.0001$ \\
\hline Smoking, $\mathrm{n}(\%)$ of current smokers & $166(17)$ & $56(17)$ & $110(17)$ & 0.9 \\
\hline $\mathrm{BMI}^{+}, \mathrm{kg} / \mathrm{m}^{2}$ & $27.8 \pm 4.2$ & $28.0 \pm 4.1$ & $27.6 \pm 4.3$ & 0.05 \\
\hline Physical activity ${ }^{\dagger}$, hrs/day & $4.0 \pm 3.0$ & $5.3 \pm 3.3$ & $3.4 \pm 2.6$ & $<0.0001$ \\
\hline $\begin{array}{l}\text { Glucose metabolic status } \\
\text { Normal, n (\%) } \\
\text { IHG, } \mathrm{n}(\%) \\
\text { Newly diagnosed T2DM, n (\%) }\end{array}$ & $\begin{array}{l}456(47) \\
218(23) \\
288(30)\end{array}$ & $\begin{array}{l}212(66) \\
72(22) \\
37(12)\end{array}$ & $\begin{array}{l}244(38) \\
146(23) \\
251(39)\end{array}$ & $<0.0001$ \\
\hline Fasting glucose $\$, \mathrm{mmol} / \mathrm{L}$ & $5.8(5.3-6.6)$ & $5.4(5.1-5.9)$ & $6.0(5.5-7.0)$ & $<0.0001$ \\
\hline 2h glucose $\$$ mmol/L & $6.5(5.2-8.3)$ & $6.4(5.1-8.1)$ & $6.6(5.4-8.3)$ & 0.3 \\
\hline $\mathrm{HbA}_{1 c} \S, \%$ & $5.8(5.5-6.2)$ & $5.7(5.4-6.0)$ & $5.9(5.6-6.4)$ & $<0.0001$ \\
\hline Fasting insulin§, pmol/L & $56(42-82)$ & $54(43-74)$ & $57(41-84)$ & 0.3 \\
\hline HOMA-IR§ & $1.1(0.8-1.6)$ & $1.0(0.8-1.4)$ & $1.1(0.8-1.7)$ & 0.1 \\
\hline Total cholesterol\$, mmol/L & $5.6(4.9-6.3)$ & $5.2(4.7-5.8)$ & $5.8(5.1-6.4)$ & $<0.0001$ \\
\hline $\mathrm{HDL}-\mathrm{C} \$, \mathrm{mmol} / \mathrm{L}$ & $1.3(1.1-1.6)$ & $1.2(1.0-1.4)$ & $1.3(1.1-1.6)$ & $<0.0001$ \\
\hline TC/HDL-C ratio§ & $4.3(3.5-5.4)$ & $4.4(3.6-5.9)$ & $4.3(3.5-5.3)$ & 0.2 \\
\hline LDL-C $\$, \mathrm{mmol} / \mathrm{L}$ & $3.6(3.0-4.2)$ & $3.3(2.8-3.9)$ & $3.7(3.1-4.2)$ & $<0.0001$ \\
\hline Triacylglycerol\$, mmol/L & $1.4(1.0-1.9)$ & $1.4(1.0-1.9)$ & $1.4(1.0-1.9)$ & 0.5 \\
\hline CRPs, II, mg/L & $2.0(1.2-3.6)$ & $2.2(1.3-3.5)$ & $2.0(1.1-3.6)$ & 0.6 \\
\hline Total energy intake ${ }^{\dagger}, \mathrm{Mj} / \mathrm{day}$ & $8.6 \pm 2.3$ & $9.4 \pm 2.5$ & $8.2 \pm 2.1$ & $<0.0001$ \\
\hline Carbohydrate intake $^{+}, \%$ energy & $45.5 \pm 6.6$ & $44.5 \pm 6.1$ & $46.0 \pm 6.8$ & 0.002 \\
\hline Protein intake ${ }^{\dagger}, \%$ energy & $15.4 \pm 2.3$ & $15.2 \pm 2.0$ & $15.5 \pm 2.4$ & 0.1 \\
\hline Fat intake ${ }^{+}, \%$ energy & $34.8 \pm 5.2$ & $35.8 \pm 4.8$ & $34.3 \pm 5.4$ & $<0.0001$ \\
\hline Fiber intake ${ }^{\dagger}, \mathrm{g} / \mathrm{MJ}$ & $2.9 \pm 0.7$ & $2.9 \pm 0.6$ & $2.9 \pm 0.7$ & 0.6 \\
\hline \multicolumn{5}{|c|}{$\begin{array}{l}\text { BMI: Body mass index; IHG: Intermediate hyperglycemia; T2DM: Type } 2 \text { diabetes mellitus; HbAic: Glycated } \\
\text { hemoglobin A1c; HOMA-IR: Homeostasis model assessment insulin resistance index; HDL-C: High density } \\
\text { lipoprotein cholesterol; TC/HDL-C ratio: Total cholesterol to high density lipoprotein cholesterol ratio; LDL-C: } \\
\text { Low density lipoprotein cholesterol; CRP: High sensitivity C-reactive protein. } \\
{ }^{*} \text { Comparison between the two studies was conducted by Wilcoxon rank sum test for continuous variable or } \\
\text { chi-square test for categorical variables. }{ }^{+} \bar{x} \pm \mathrm{SD} \text {. } ¥ \text { Based on GI of glucose }=100 \text { scale. }{ }^{\S} \text { Median (inter-quartile } \\
\text { range). } \| \text { Those with CRP }>10 \mathrm{mg} / \mathrm{L} \text { were excluded from the calculation. }\end{array}$} \\
\hline
\end{tabular}

\section{Results}

The study population consisted of 517 men and 457 women; 30\% of them had newly diagnosed T2DM and 23\% had intermediate hyperglycemia (IHG, including impaired glucose tolerance and impaired fasting glycemia) (Table 3-1). The subjects 
were on average $65 \pm 9$ (mean \pm SD) yrs old (range: $42-87 \mathrm{yrs}$ ), with a mean GI of $57 \pm$ 4 and a mean GL of $130 \pm 39$. Compared to the subjects from the CoDAM study, the Hoorn population was on average older (58 vs. 68 yrs), included slightly less men ( $50 \%$ vs. $60 \%$ ) and more newly diagnosed T2DM patients ( $39 \%$ vs. $12 \%$ ), and were less physically active ( $3.4 \mathrm{vs.} 5.3 \mathrm{hrs} / \mathrm{d})$.

The dairy products group was inversely associated with GI and it contributed most $(30 \%)$ to the inter-individual variation in GI. The group of fruits was also inversely associated with GI and predicted $6 \%$ of the variation in GI. The group of potatoes and other tubers and the group of cereals and cereal products were positively associated with GI and they respectively accounted for $17 \%$ and $7 \%$ of the variation in GI (Table 3-2). In total, these four groups accounted for $61 \%$ of the GI variation. GL was positively associated with all 17 food groups except vegetables. Six carbohydrate-rich food groups explained in total $85 \%$ of the variation in GL. The most predictive food group was cereal products, which explained $43 \%$ of the variation, followed by sugar and confectionery $(23 \%)$.

Table 3-2. Food groups contributing to the inter-individual variation of GI and GL ( $n=974)$.

\begin{tabular}{|c|c|c|c|}
\hline Food groups * & $B(S E)^{+}$ & Partial R² & Model R ${ }^{2}$ \\
\hline \multicolumn{4}{|l|}{ GI } \\
\hline Dairy products & $-0.66(0.03)$ & 0.30 & 0.30 \\
\hline Potatoes and other tubers & $1.84(0.11)$ & 0.17 & 0.48 \\
\hline Cereals and cereal products & $1.43(0.11)$ & 0.07 & 0.55 \\
\hline Fruits & $-0.69(0.06)$ & 0.06 & 0.61 \\
\hline \multicolumn{4}{|l|}{ GL } \\
\hline Cereals and cereal products & $19.96(0.70)$ & 0.43 & 0.43 \\
\hline Sugars and confectionery & $42.04(1.71)$ & 0.23 & 0.66 \\
\hline Potatoes and other tubers & $13.04(0.64)$ & 0.09 & 0.75 \\
\hline Cakes & $27.12(1.74)$ & 0.07 & 0.81 \\
\hline Fruits & $4.13(0.33)$ & 0.03 & 0.84 \\
\hline Dairy products & $0.72(0.18)$ & 0.01 & 0.85 \\
\hline
\end{tabular}

Both GI and GL were positively associated with total energy intake $\left(\mathrm{r}_{\mathrm{s}}=0.17\right.$ and 0.82 respectively) (Table 3-3). In crude analyses, GI was positively associated with most of the nutrients but inversely associated with the intake of mono- and disaccharides, animal protein and alcohol; GL was positively associated with all nutrients under investigation. After the adjustment for total energy intake by using partial regression analysis, GI was strongly and positively associated with polysaccharides $\left(r_{s}=0.61\right)$, plant protein $\left(r_{s}=0.32\right)$, total fat $\left(r_{s}=0.17\right)$, PUFA $\left(r_{s}=0.20\right)$ and MUFA $\left(r_{s}=0.15\right)$ but inversely associated with mono-and disaccharides $\left(r_{s}=-\right.$ 
$0.38)$, animal protein $\left(r_{s}=-0.26\right)$, alcohol $\left(r_{s}=-0.18\right)$ and total protein $\left(r_{s}=-0.16\right)$. Total carbohydrates and fiber were only weakly associated with GI and the association of GI with saturated fat and cholesterol were not statistically significant. GL was positively associated with the intake of total carbohydrates $\left(\mathrm{r}_{\mathrm{s}}=0.92\right)$, polysaccharides $\left(r_{s}=0.63\right)$, mono- and disaccharides $\left(r_{s}=0.49\right)$, plant protein $\left(r_{s}=0.43\right)$ and fiber $\left(r_{s}=0.38\right)$, but inversely associated with the other nutrients (Table 3-3).

\begin{tabular}{|c|c|c|c|c|}
\hline \multirow[t]{2}{*}{ Nutrients $^{\dagger}$} & \multicolumn{2}{|c|}{ GI } & \multicolumn{2}{|c|}{ GL } \\
\hline & $\mathrm{rs}_{\mathrm{s}}$ & $\mathrm{r}_{\text {s_adj }}$ & $\mathrm{r}_{\mathrm{s}}$ & $\mathrm{r}_{\mathrm{s} \_a d j}$ \\
\hline Total energy, Mj/d & $0.17^{* *}$ & - & $0.82^{* *}$ & - \\
\hline Total carbohydrate, g/d & $0.18^{* *}$ & $0.06^{* *}$ & $0.97^{* *}$ & $0.92^{* *}$ \\
\hline Total fat, g/d & $0.23^{* *}$ & $0.17^{* *}$ & $0.62^{* *}$ & $-0.42^{* *}$ \\
\hline Total protein, g/d & 0.05 & $-0.16^{* *}$ & $0.59^{* *}$ & $-0.29^{* *}$ \\
\hline Polysaccharides, g/d & $0.51^{* *}$ & $0.61^{* *}$ & $0.86^{* *}$ & $0.63^{* *}$ \\
\hline Mono- and disaccharides, g/d & $-0.21^{* *}$ & $-0.38^{* *}$ & $0.70^{* *}$ & $0.49^{* *}$ \\
\hline Saturated fat, g/d & $0.18^{* *}$ & 0.06 & $0.60^{* *}$ & $-0.31^{* *}$ \\
\hline Polyunsaturated fat, g/d & $0.26^{* *}$ & $0.20^{* *}$ & $0.56^{* *}$ & $-0.10^{* *}$ \\
\hline Monounsaturated fat, g/d & $0.22^{* *}$ & $0.15^{* *}$ & $0.57^{* *}$ & $-0.47^{* *}$ \\
\hline Animal protein, $\mathrm{g} / \mathrm{d}$ & $-0.09^{* *}$ & $-0.26^{* *}$ & $0.32^{* *}$ & $-0.41^{* *}$ \\
\hline Plant protein, g/d & $0.33^{* *}$ & $0.32^{* *}$ & $0.80^{* *}$ & $0.43^{* *}$ \\
\hline Fiber intake, g/d & $0.17^{* *}$ & $0.08^{* *}$ & $0.69^{* *}$ & $0.38^{* *}$ \\
\hline Cholesterol, mg/day & $0.12^{* *}$ & 0.02 & $0.36^{* *}$ & $-0.37^{* *}$ \\
\hline Alcohol, g/d & $-0.10^{* *}$ & $-0.18^{* *}$ & 0.05 & $-0.49^{* *}$ \\
\hline
\end{tabular}

GI was positively associated with insulin resistance indicated by both the concentration of fasting insulin and HOMA-IR level (Table 3-4). A 10-unit GI increment, which corresponds to the difference between the lowest and highest quintile, was significantly associated with a $23 \%$ increase in markers of insulin resistance. The association of GI with HDL-C (inverse) and CRP (positive) concentration and TC/HDL-C ratio (positive) was also statistically significant. A 10unit increase in GI was associated with 7\% decrease in HDL-C concentration, 10\% increase in TC/HDL-C ratio and $29 \%$ increase in CRP concentration. In addition, this amount of GI increase was also associated with $10 \%$ increase in TG concentration, although this association was not statistically significant. In contrast, GL was not significantly associated with any of the metabolic risk factors, except for a borderline positive association with CRP.

Neither GI nor GL was significantly associated with BMI and waist circumference after the adjustment for age, gender and physical activity level (data not shown). The only significant interaction was between GI and smoking in the association with fasting glucose $(P=0.02)$, fasting insulin $(P=0.04)$ and HOMA-IR $(P$ 
$=0.04$ ). Additional stratified analyses showed that the positive associations between GI and these metabolic factors were confined to non-smokers, and absent in current smokers (data not shown).

Table 3-4. Associations of GI and GL and metabolic risk factors $(\mathbf{n}=974)^{*}$.

\begin{tabular}{|c|c|c|c|c|}
\hline \multirow{2}{*}{ Metabolic factors } & \multicolumn{2}{|c|}{ GI (10 units) } & \multicolumn{2}{|c|}{ GL (50 units) } \\
\hline & $B(S E)$ & $P$ & $B(S E)$ & $P$ \\
\hline Fasting glucose, $\mathrm{mmol} / \mathrm{L}$ & $0.02(0.01)$ & 0.09 & $0.004(0.009)$ & 0.7 \\
\hline $2 \mathrm{~h}$ - glucose, $\mathrm{mmol} / \mathrm{L}$ & $0.02(0.02)$ & 0.4 & $-0.01(0.02)$ & 0.6 \\
\hline $\mathrm{HbA}_{1 \mathrm{c}}, \%$ & $0.004(0.008)$ & 0.6 & $-0.001(0.006)$ & 0.8 \\
\hline Fasting insulin, pmol/L & $0.09(0.03)$ & 0.005 & $0.03(0.03)$ & 0.2 \\
\hline HOMA-IR & $0.09(0.03)$ & 0.004 & $0.03(0.03)$ & 0.3 \\
\hline Total cholesterol, $\mathrm{mmol} / \mathrm{L}$ & $0.006(0.01)$ & 0.6 & $0.004(0.009)$ & 0.7 \\
\hline HDL-C, mmol/L & $-0.03(0.02)$ & 0.04 & $0.0001(0.01)$ & 1.0 \\
\hline TC/HDL-C ratio & $0.04(0.02)$ & 0.04 & $0.004(0.02)$ & 0.8 \\
\hline LDL-C, mmol/L & $0.01(0.02)$ & 0.4 & $-0.003(0.01)$ & 0.8 \\
\hline Triacylglycerol, mmol/L & $0.04(0.03)$ & 0.1 & $0.002(0.02)$ & 0.9 \\
\hline $\mathrm{CRP}^{+}, \mathrm{mg} / \mathrm{L}$ & $0.11(0.06)$ & 0.05 & $0.08(0.05)$ & 0.09 \\
\hline \multicolumn{5}{|c|}{$\begin{array}{l}\text { B: Regression coefficient; SE: Standard error of } B \text {; HbAic: Glycated hemoglobin Aic; HOMA-IR: Insulin } \\
\text { resistance index from homeostasis model assessment; HDL-C: High density lipoprotein cholesterol; TC/HDL- } \\
\text { C ratio: Total cholesterol to high density lipoprotein cholesterol ratio; LDL-C: Low density lipoprotein } \\
\text { cholesterol, CRP: high sensitivity C-reactive protein. } \\
{ }^{*} \text { Multiple linear regression analysis was used with log-transformed metabolic risk factor as response variable } \\
\text { and GI or GL as main exposure variable. Adjustment was made for age, gender, smoking, physical activity, } \\
\text { cohort, and the intake of total energy, alcohol, fiber, cholesterol, animal protein, plant protein and saturated } \\
\text { fatty acids (SFA). For GI, also adjusted for monounsaturated fatty acids (MUFA), polyunsaturated fatty acids } \\
\text { (PUFA), polysaccharides and mono- and disacharides. Total energy intake was adjusted for via using } \\
\text { residual method. }{ }^{+} \text {Analyses confined to those with CRP }<=10 \mathrm{mg} / \mathrm{L} \text {. }\end{array}$} \\
\hline
\end{tabular}

\section{Discussion}

In this study population, a low GI diet was characterized by a high dairy and fruit and a low potato and cereal intake. GI was inversely associated with HDL-C and positively associated with fasting insulin, HOMA-IR, TC/HDL-C ratio and CRP. In non-smokers, it was also associated with fasting glucose. In contrast, GL was not clearly associated with any of these risk factors.

Previous studies on GI/GL and metabolic risk factors showed inconsistencies. ${ }^{9}, 12$ We used a newly developed GI database which for European studies incorporates the best knowledge in the field so far. ${ }^{23}$ This enabled us to study the association with metabolic risk factors in a more optimal way. We acknowledge the difficulties and inaccuracy in assessing GI and GL using FFQs. ${ }^{39}$ However, the validity in terms of estimating carbohydrate intake of our FFQ is comparable to that used in the Nurses' Health study ${ }^{40}$ and is for example higher than the FFQ used in the Insulin Resistance Atherosclerosis Study. ${ }^{16}$ Moreover, GI values were assigned to foods providing 98\% of the total available carbohydrate consumption, which was slightly higher than in previous reports. $13,41,42$ 
We analyzed the pooled data of two Dutch cohort studies to increase the statistical power. Although baseline characteristics differed mainly due to the age and sex-differences between the two studies, pooling the data was justified as statistical analyses of interaction term in regression models showed no evidence of effect modification. In addition, in both studies, a common examination protocol was used, general questionnaires and FFQ were the same, and biochemical measurements were mostly done in the same laboratory, which ensures the lack of bias. Analyses of metabolic factors were adjusted for an extended set of potential confounders including age, gender, smoking, physical activity, cohort, total energy, dietary fiber, alcohol and cholesterol intake. For GI, additional adjustment was made for fatty acids, plant- and animal-based protein, polysaccharides and mono- and disaccharides. Therefore, the observed associations are not likely to be explained by a different dietary composition. For GL, additional adjustment was made for animaland plant-based protein and SFA, but not MUFA and PUFA. Thus, the observed associations represented substituting unsaturated fatty acids (PUFA and MUFA) with GL. In a post hoc analysis, models substituting either animal protein or plant protein with GL yielded essentially the same results. Thus in this population a low GL diet is not different from a high unsaturated fat or high protein diet in its associations with metabolic risk factors.

The concern that low GI diets may limit food choices and increase fat intake 22 was not supported by our findings. Actually, we found a moderate positive association between GI and fat intake, both unadjusted and adjusted for total energy. At the food level, GI was positively associated with the intake of meats, and fats and oils, but inversely associated with the intake of vegetables, legumes, fruits, and fish. These findings imply that a low GI diet may be a marker of healthy eating habits. The positive association between GI and foods containing negligible amounts of carbohydrates, including meats and fats and oils, was also found in a previously published US study. ${ }^{43}$ An explanation may be that these foods are usually consumed in combination with high GI foods such as potatoes and cereals.

The association between GI and dairy products was consistent with previous findings among Dutch elderly men ${ }^{12}$ and US population. ${ }^{43}$ Unexpectedly, GI and GL in our study were positively, not inversely, associated with total dietary fiber intake. This supports the notion that low GI and GL diets are not necessarily high in fiber, and attributing the health effects of low GI and GL diets to higher fiber content may be imprudent. Separating soluble and insoluble fiber may shed more light on this issue, but was currently not possible due to lack of information in the Dutch food composition table.

Regarding alcohol, some found an inverse association with GI, ${ }^{40,44}$ while others found the opposite. ${ }^{43}$ In this study, we found a modest inverse association between GI and GL and alcohol intake. Different approaches used to assign GI values to alcoholic beverages might be, at least partly, the explanation for these dissimilar findings. In our study, the GI values of most alcoholic drinks, except for beer, 
liqueurs and cocktails ( $\mathrm{GI}=61$ vs. glucose), were 0 , while Schulz et al. assigned an estimated GI value of 95 to beer and a value of 61 to wine and other alcoholic beverages..$^{43}$ More information on the GI values of alcoholic beverages in different countries may be needed.

GL was strongly associated with intake of total carbohydrates $\left(r_{s}=0.97\right)$ but only moderately associated with GI $\left(\mathrm{r}_{\mathrm{s}}=0.41\right)$. Over $95 \%$ of the variation in GL was explained by total carbohydrates, and only about $4 \%$ by GI. Compared with what has been demonstrated by Brand-Miller et al, ${ }^{45} \mathrm{GL}$ in our study depended more heavily $(95 \%$ vs. $68 \%$ ) on carbohydrate intake. This might be secondary to the smaller variation in GI than in carbohydrate intake. Previous epidemiological studies showing similar variation of GI did however not report the relationship of GL with carbohydrates. ${ }^{10,16,42}$

Mechanisms involved in the association of GI and GL with blood glucose, insulin and lipid concentrations have been reviewed before. ${ }^{14}$ In addition to the significant inverse association between GI and HDL-C, we also observed a positive association between GI and the TC/HDL-C ratio. The TC/HDL-C ratio is considered the best predictor of ischemic heart diseases as it takes into account both the cardioprotective effect of HDL-C and the atherogenic effect of LDL-C and very low density lipoprotein cholesterol (VLDL-C). ${ }^{46}$ Although small, the significant association of GI with HDL-C and TC/HDL-C ratio suggests a protective role of low GI diets on lipid metabolism disorders and CVD.

Potential mechanisms underlying the association between GI, GL and chronic systematic inflammation have recently been summarized in detail. ${ }^{47}$ Hyperglycemia, dyslipidemia, insulin resistance and weight change may all be involved in this pathway. A positive relationship between GI, GL and CRP was found previously in two US studies.10,48 Although the association was only of borderline significance for GL, a $29 \%$ decrease in CRP by 10 unit GI decrease seems promising for decreasing the risk of metabolic syndrome and CVD. ${ }^{49}$

Low GI diets showed significant benefits on fasting glucose and insulin sensitivity among non-smokers. None of the previous studies on GI and GL has reported this effect modification. It may be that the independent adverse effects of cigarette smoking on glucose and insulin metabolism leaves little room for the main exposure variables, as in a study on beta-carotene, ${ }^{50}$ although this is rather unlikely in comparison with stronger determinants of glucose metabolism, such as BMI and waist. Further investigation on the potential impacts of smoking on nutrient (carbohydrates) partitioning may be needed.

It should also be noted that the current findings resulted from analyses that included both polysaccharides and mono- and disaccharides as covariates. This was due to the fact that GI in our study, also in a US study, ${ }^{43}$ was positively associated with polysaccharides but inversely associated with mono- and disaccharides. When we adjusted for total carbohydrate instead, GI was not significantly associated with fasting insulin and HOMA-IR, whereas the association with lipids and CRP 
remained essentially the same. This suggests that low GI diets may benefit insulin sensitivity via replacing high GI polysaccharides with low GI polysaccharides but not replacing polysaccharides with mono- and disaccharides.

In this study, GI and GL were not associated with $\mathrm{HbA}_{1 \mathrm{c}}$, a marker of long term glycemic control. Although more than half of the subjects had T2DM or IHG, HbAic was on average in the low diabetic and normal range. Subgroup analyses among T2DM patients $(\mathrm{n}=288)$, subjects with either T2DM or IHG $(\mathrm{n}=506)$ and subjects with a high $\mathrm{HbA}_{1 \mathrm{c}}$ level $(7 \%, \mathrm{n}=78)$ also failed to detect any statistically significant association.

In conclusion, in this Dutch population, a low GI diet is high in dairy products and fruits but low in potatoes and cereals. Even though cross-sectional studies do not prove a causal relationship, the findings of this current study support a beneficial role of low GI diets in optimizing insulin sensitivity, lipid metabolism, chronic inflammation and, in non-smokers, fasting glucose. GL was highly correlated with total carbohydrates and marginally associated with CRP but not other metabolic risk factors under investigation. Large prospective cohort studies and clinical trials are warranted to ascertain the beneficial effects cast on low GI diets.

\section{References}

1. Jenkins DJ, Wolever TM, Taylor RH, et al. Glycemic index of foods: a physiological basis for carbohydrate exchange. Am J Clin Nutr. Mar 1981;34(3):362-366.

2. Salmeron J, Manson JE, Stampfer MJ, et al. Dietary fiber, glycemic load, and risk of non-insulindependent diabetes mellitus in women. Jama. Feb 12 1997;277(6):472-477.

3. Murakami K, Sasaki S, Okubo H, et al. Dietary fiber intake, dietary glycemic index and load, and body mass index: a cross-sectional study of 3931 Japanese women aged 18-20 years. Eur J Clin Nutr. 2007;61(8):986-995.

4. Liu S, Willett WC, Stampfer MJ, et al. A prospective study of dietary glycemic load, carbohydrate intake, and risk of coronary heart disease in US women. Am J Clin Nutr. Jun 2000;71(6):1455-1461.

5. Silvera SA, Rohan TE, Jain M, et al. Glycaemic index, glycaemic load and risk of endometrial cancer: a prospective cohort study. Public Health Nutr. Oct 2005;8(7):912-919.

6. Chiu CJ, Hubbard LD, Armstrong J, et al. Dietary glycemic index and carbohydrate in relation to early age-related macular degeneration. Am J Clin Nutr. Apr 2006;83(4):880-886.

7. Food and Agriculture Organization of the United Nations, The World Health Orgination. Cabohydrates in Human Nutrition. A summary of the Joint FAO/WHO Expert Consultation. Rome; 1997.

8. Sheard NF, Clark NG, Brand-Miller JC, et al. Dietary carbohydrate (amount and type) in the prevention and management of diabetes: a statement by the american diabetes association. Diabetes Care. Sep 2004;27(9):2266-2271.

9. Liu S, Manson JE, Stampfer MJ, et al. Dietary glycemic load assessed by food-frequency questionnaire in relation to plasma high-density-lipoprotein cholesterol and fasting plasma triacylglycerols in postmenopausal women. Am J Clin Nutr. Mar 2001;73(3):560-566.

10. Liu S, Manson JE, Buring JE, et al. Relation between a diet with a high glycemic load and plasma concentrations of high-sensitivity C-reactive protein in middle-aged women. Am J Clin Nutr. Mar 2002;75(3):492-498.

11. Frost G, Leeds AA, Dore CJ, et al. Glycaemic index as a determinant of serum HDL-cholesterol concentration. Lancet. Mar 27 1999;353(9158):1045-1048. 
12. van Dam RM, Visscher AW, Feskens EJ, et al. Dietary glycemic index in relation to metabolic risk factors and incidence of coronary heart disease: the Zutphen Elderly Study. Eur J Clin Nutr. Sep 2000;54(9):726-731.

13. Oxlund AL, Heitmann BL. Glycaemic index and glycaemic load in relation to blood lipids - 6 years of follow-up in adult Danish men and women. Public Health Nutr. Sep 2006;9(6):737-745.

14. Du H, van der A DL, Feskens EJ. Dietary glycaemic index: a review of the physiological mechanisms and observed health impacts. Acta Cardiol. Aug 2006;61(4):383-397.

15. McKeown NM, Meigs JB, Liu S, et al. Carbohydrate nutrition, insulin resistance, and the prevalence of the metabolic syndrome in the Framingham Offspring Cohort. Diabetes Care. Feb 2004;27(2):538546.

16. Liese AD, Schulz M, Fang F, et al. Dietary glycemic index and glycemic load, carbohydrate and fiber intake, and measures of insulin sensitivity, secretion, and adiposity in the Insulin Resistance Atherosclerosis Study. Diabetes Care. Dec 2005;28(12):2832-2838.

17. Opperman AM, Venter CS, Oosthuizen $\mathrm{W}$, et al. Meta-analysis of the health effects of using the glycaemic index in meal-planning. Br J Nutr. Sep 2004;92(3):367-381.

18. Brand-Miller JC, Petocz $P$, Colagiuri S. Meta-analysis of low-glycemic index diets in the management of diabetes: response to Franz. Diabetes Care. Dec 2003;26(12):3363-3364; author reply 3364-3365.

19. Buyken AE, Toeller M, Heitkamp G, et al. Glycemic index in the diet of European outpatients with type 1 diabetes: relations to glycated hemoglobin and serum lipids. Am J Clin Nutr. Mar 2001;73(3):574-581.

20. Sahyoun NR, Anderson AL, Kanaya AM, et al. Dietary glycemic index and load, measures of glucose metabolism, and body fat distribution in older adults. Am J Clin Nutr. Sep 2005;82(3):547-552.

21. Murakami K, Sasaki S, Takahashi $Y$, et al. Dietary glycemic index and load in relation to metabolic risk factors in Japanese female farmers with traditional dietary habits. Am J Clin Nutr. May 2006;83(5):1161-1169.

22. Gilbertson HR, Thorburn AW, Brand-Miller JC, et al. Effect of low-glycemic-index dietary advice on dietary quality and food choice in children with type 1 diabetes. Am J Clin Nutr. Jan 2003;77(1):83-90.

23. Cust AE, Slimani N, Kaaks R, et al. Dietary carbohydrates, glycemic index, glycemic load, and endometrial cancer risk within the European Prospective Investigation into Cancer and Nutrition cohort. Am J Epidemiol. Oct 15 2007;166(8):912-923.

24. Kruijshoop M, Feskens EJ, Blaak EE, et al. Validation of capillary glucose measurements to detect glucose intolerance or type 2 diabetes mellitus in the general population. Clin Chim Acta. Mar 2004;341(1-2):33-40.

25. Mooy JM, Grootenhuis PA, de Vries H, et al. Prevalence and determinants of glucose intolerance in a Dutch caucasian population. The Hoorn Study. Diabetes Care. Sep 1995;18(9):1270-1273.

26. Henry RM, Kostense PJ, Spijkerman AM, et al. Arterial stiffness increases with deteriorating glucose tolerance status: the Hoorn Study. Circulation. Apr 29 2003;107(16):2089-2095.

27. Ocke MC, Bueno-de-Mesquita HB, Goddijn HE, et al. The Dutch EPIC food frequency questionnaire. I. Description of the questionnaire, and relative validity and reproducibility for food groups. Int J Epidemiol. 1997;26 Suppl 1:S37-48.

28. Ocke MC, Bueno-de-Mesquita HB, Pols MA, et al. The Dutch EPIC food frequency questionnaire. II. Relative validity and reproducibility for nutrients. Int J Epidemiol. 1997;26 Suppl 1:S49-58.

29. Brustad M, Skeie G, Braaten T, et al. Comparison of telephone vs face-to-face interviews in the assessment of dietary intake by the $24 \mathrm{~h}$ recall EPIC SOFT program--the Norwegian calibration study. Eur J Clin Nutr. Jan 2003;57(1):107-113.

30. NEVO Foundation (Stichting Nederlands Voedingsstoffenbestand). Dutch Food Composition Table (Nederlands voedingsstoffenbestand, NEVO Table): Dutch Nutrition Center (Voedingscentrum/Voorlichtingsbureau voor de Voeding), Den Haag; 1996.

31. The official website of the glycemic index and GI database www.glycemicindex.com. Human Nutrition Unit, University of Sydney.

32. Foster-Powell $\mathrm{K}$, Holt SH, Brand-Miller JC. International table of glycemic index and glycemic load values: 2002. Am J Clin Nutr. Jul 2002;76(1):5-56. 
33. Henry CJ, Lightowler HJ, Strik CM, et al. Glycaemic index and glycaemic load values of commercially available products in the UK. Br J Nutr. Dec 2005;94(6):922-930.

34. Deckers JG, Schellevis FG, Fleming DM. WHO diagnostic criteria as a validation tool for the diagnosis of diabetes mellitus: a study in five European countries. Eur J Gen Pract. 2006;12(3):108-113.

35. HOMA Calculator v2.2 [computer program]. Version: Diabetes Trials Unit, Oxford Centre for Diabetes, Endocrinology and Metabolism. Headington, Oxford, UK; 2004.

36. Friedewald WT, Levy RI, Fredrickson DS. Estimation of the concentration of low-density lipoprotein cholesterol in plasma, without use of the preparative ultracentrifuge. Clin Chem. Jun 1972;18(6):499502.

37. Wendel-Vos GC, Schuit AJ, Saris WH, et al. Reproducibility and relative validity of the short questionnaire to assess health-enhancing physical activity. J Clin Epidemiol. Dec 2003;56(12):1163-1169.

38. Willett WC. Anthropometric measures and body composition. Nutritional Epidemiology. 2nd edition. New York: Oxford University Press; 1998.

39. Neuhouser ML, Tinker LF, Thomson C, et al. Development of a glycemic index database for food frequency questionnaires used in epidemiologic studies. J Nutr. Jun 2006;136(6):1604-1609.

40. Schulze MB, Liu S, Rimm EB, et al. Glycemic index, glycemic load, and dietary fiber intake and incidence of type 2 diabetes in younger and middle-aged women. Am J Clin Nutr. Aug 2004;80(2):348356.

41. Amano Y, Kawakubo K, Lee JS, et al. Correlation between dietary glycemic index and cardiovascular disease risk factors among Japanese women. Eur J Clin Nutr. Nov 2004;58(11):1472-1478.

42. Milton JE, Briche B, Brown IJ, et al. Relationship of glycaemic index with cardiovascular risk factors: analysis of the National Diet and Nutrition Survey for people aged 65 and older. Public Health Nutr. Apr 24 2007:1-15.

43. Schulz M, Liese AD, Mayer-Davis EJ, et al. Nutritional correlates of dietary glycaemic index: new aspects from a population perspective. Br J Nutr. Sep 2005;94(3):397-406.

44. Larsson SC, Bergkvist L, Wolk A. Glycemic load, glycemic index and carbohydrate intake in relation to risk of stomach cancer: A prospective study. Int J Cancer. Jan 4 2006;118(12):3167-3169.

45. Brand-Miller JC, Holt SH, Petocz P. Reply to R Mendosa. Am J Clin Nutr. 2003;77:994-995.

46. Lemieux I, Lamarche B, Couillard C, et al. Total cholesterol/HDL cholesterol ratio vs LDL cholesterol/HDL cholesterol ratio as indices of ischemic heart disease risk in men: the Quebec Cardiovascular Study. Arch Intern Med. Dec 10-24 2001;161(22):2685-2692.

47. Qi L, Hu FB. Dietary glycemic load, whole grains, and systemic inflammation in diabetes: the epidemiological evidence. Curr Opin Lipidol. Feb 2007;18(1):3-8.

48. Pereira MA, Swain J, Goldfine AB, et al. Effects of a low-glycemic load diet on resting energy expenditure and heart disease risk factors during weight loss. Jama. Nov 24 2004;292(20):2482-2490.

49. Ridker PM. C-reactive protein, inflammation, and cardiovascular disease: clinical update. Tex Heart Inst J. 2005;32(3):384-386.

50. Hozawa A, Jacobs DR, Jr., Steffes MW, et al. Associations of serum carotenoid concentrations with the development of diabetes and with insulin concentration: interaction with smoking: the Coronary Artery Risk Development in Young Adults (CARDIA) Study. Am J Epidemiol. May 15 2006;163(10):929-937. 


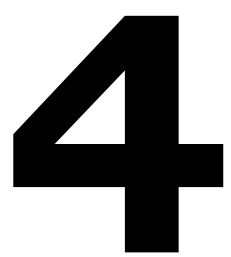

\title{
Reproducibility and relative validity of dietary glycemic index and glycemic load assessed by the Dutch EPIC FFQ
}

H. Du, D. L. van der A, M. M.E. van Bakel, L. D. Verberne,

M. Ocke, E. J.M. Feskens.

Br J Nutr. 2009;102:601-604

\begin{abstract}
Limited information is available on the reproducibility and validity of dietary glycemic index (GI) and glycemic load (GL) estimated by habitual diet assessment methods such as food-frequency questionnaires (FFQs), including the FFQ used in the Dutch cohorts of the European Prospective Investigation into Cancer and Nutrition (EPIC) study. To examine the reproducibility and relative validity of GI and GL, we used data from 121 Dutch men and women aged 23-72 years. They completed the FFQ three times at intervals of 6 months and twelve 24-hour dietary recalls (24HDRs) monthly during 1991-1992. GI and GL were calculated using published values. Intra-class correlation coefficients of the three repeated FFQs were 0.78 for GI and 0.74 for GL. Pearson correlation coefficients between the first FFQ and the weighted average of the 24HDRs were 0.63 for both GI and GL. Weighted kappa values between the first FFQ and the average of the 24HDRs (in quintiles) were 0.40 for GI and 0.41 for GL. Bland-Altman plots showed a proportional bias in GI $(\beta=0.46)$ but not in GL $(\beta=0.06)$. In conclusion, this FFQ can be used in epidemiological studies to investigate the relationship of GI and GL with disease risks but the proportional bias should be taken into account when using this FFQ to assess the absolute GI values.
\end{abstract}

Key words

Glycemic index; Glycemic load; Reproducibility; Validity; Food frequency questionnaire

\section{Introduction}

The food-frequency questionnaire (FFQ) is the most frequently used method to assess habitual diets in large scale epidemiological studies given that it is relatively inexpensive and less labor demanding as compared to for example food diaries or 24 
hour dietary recalls (24HDRs). Dietary glycemic index (GI) and glycemic load (GL) have recently been considered as potential risk factors of chronic diseases such as type 2 diabetes, heart diseases and certain types of cancer. ${ }^{1}$ Several epidemiological studies have been conducted investigating the potential role of dietary GI and GL on disease risks. ${ }^{2-5}$ However, none of the FFQs used in these studies are specifically designed for measuring dietary GI and GL and the reproducibility and validity of GI and GL assessed by these FFQs are mostly unknown.

The FFQ used in the Dutch cohorts of the European Prospective Investigation into Cancer and Nutrition (EPIC) study was designed to capture the habitual intake of nutrients and major food items of the Dutch adult population. It is a selfadministered semi-quantitative FFQ, contains 178 food items, and has also been used by other Dutch studies apart from EPIC. ${ }^{3}$ The reproducibility and validity of energy, food and nutrient intake have been investigated before.6, 7 The current study was conducted, using previously collected data, to examine the reproducibility and relative validity of GI and GL estimated by this FFQ.

\section{Methods}

\section{Subjects, study design and dietary assessment}

A detailed description of the subject recruitment, FFQ, reference method, data collection and data processing has been published previously. ${ }^{6}$ In brief, the subjects were recruited from the study populations of the Dutch part of the EPIC study from 4 towns in The Netherlands. Of the 960 people invited by mail, 240 (25\%) responded positively, 288 (30\%) refused to participate, and $432(45 \%)$ did not respond. Out of the 240 who responded positively, we selected 134 subjects equally distributed across the four towns, in 20-year age groups and of both genders. In total 121 subjects, 63 men and 58 women, completed the study. They were between 23 and 72 years old and had a mean body mass index (BMI) of $25.2 \mathrm{~kg} / \mathrm{m}^{2}$. During 1991-1992, the FFQ was administered three times with intervals of 6 months by mailing to the participants at home. 24HDRs (one for each weekend day, and two for each weekday) were administered monthly throughout a year either face to face or by telephone interview. Nutrient intake was calculated according to the 1993 version of the Dutch food composition table (Nederlands Voedingsstoffenbestand table, NEVO table). ${ }^{8}$ Weighted average of 24HDRs was calculated with weight of 1 for weekdays and 2 for weekend days.

\section{GI and GL calculation}

In order to calculate dietary GI and GL, GI values were assigned to every carbohydrate-containing food item included in the FFQ and 24HDRs. The GIdatabase developed in the EPIC study was used as the main source of information. Methodologies used to compile this GI-database have been briefly explained before ${ }^{2}$, ${ }^{3}$ and a full descriptive paper is going to be published elsewhere. ${ }^{9}$ In brief, this GI table was compiled from different published sources, ${ }^{10-12}$ including 415 values from 
the international table of GI and GL values from Foster-Powell et al, ${ }^{10} 31$ published values for British foods, 119 foods from the official website of the Glycemic Index and GI Database from the Sydney University, ${ }^{12}$ and 20 communicated values for food (groups) with no equivalent in above mentioned sources (Thomas Wolever and Jennie Brand-Miller, personal communication). For the Foster-Powell table, a few adaptations were made according to a prioritized selection list of criteria developed by the $\mathrm{FAO} / \mathrm{WHO}$ expert consultation. For example, items that were not measured under standard conditions were excluded if items analyzed under standard conditions were already available in the table (standard conditions include: $50 \mathrm{~g}$ or, in case of low carbohydrate containing foods, $25 \mathrm{~g}$ of available carbohydrate, measurement time for healthy and diabetic subjects of 2 and 3 hours respectively, and at least 6 participants). ${ }^{9}$ All food items in the FFQ could be linked to a GI value in this GI-database. For about 30\% (258 out of 764 ) of the items in the 24HDRs, no direct link was possible. So a GI value from other sources had to be assigned. For this, the same sources of information and criteria as used in the compilation of the EPIC GI-database were applied. Dietary GI and GL were calculated as the weighted mean of GI and GL from all foods consumed daily using the commonly used formulas. ${ }^{3}$

\section{Statistical method}

To assess reproducibility, intra-class correlation coefficients (ICCs) were calculated.

To assess relative validity, Pearson correlation coefficients and weighted kappa statistics were calculated for the first FFQ and the average of the 24HDRs. Absolute agreement between two measurements was determined using the Bland-Altman method, in which the difference was plotted against the mean of the two dietary assessment methods. Linear regression analysis was performed to investigate whether the bias was proportional to the levels of GI and GL. Residual method was used to adjust for energy intake. ${ }^{13}$

Statistical analyses were performed using SAS version 9.1 (SAS Institute, Cary, NC) and SPSS 15.0 for Windows (SPSS Inc, Chicago, IL, USA).

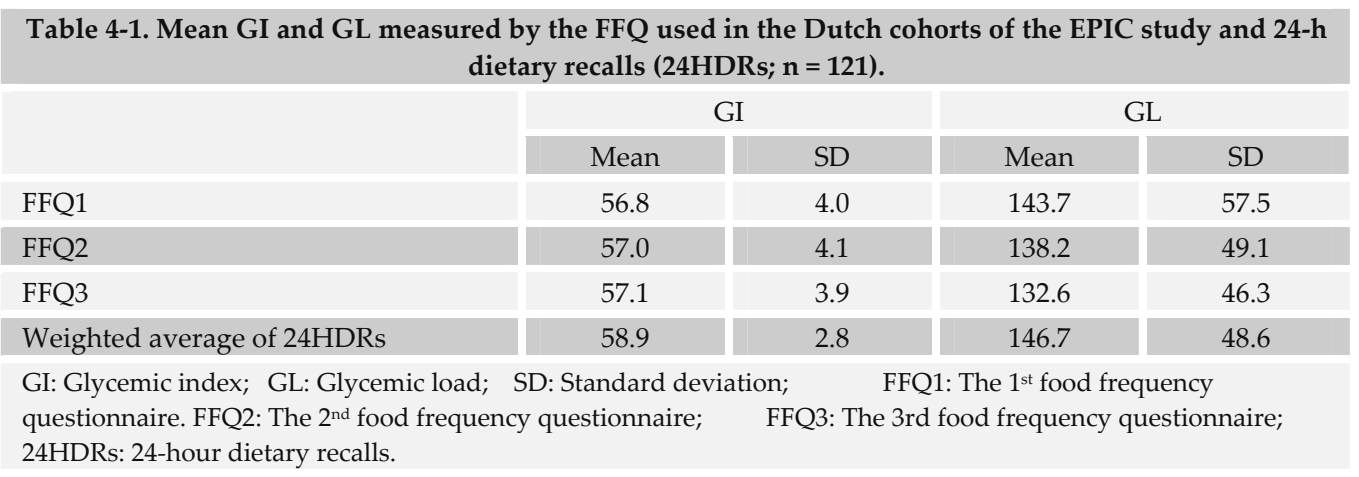




\section{Results}

Mean and standard deviation (SD) of GI and GL as assessed by the FFQs and 24HDRs are shown in Table 4-1. Both GI and GL were roughly normally distributed (data not shown). No gender differences were observed. Therefore analyses were performed in combined population of men and women. Crude ICCs between three repeated FFQs were 0.82 for GI and 0.86 for GL (Table 4-2). Adjusting for energy intake slightly attenuated the correlation coefficients to 0.78 for GI and 0.74 for GL.

\begin{tabular}{|c|c|c|c|c|}
\hline \multirow[b]{2}{*}{ Reproducibility and validity } & \multicolumn{2}{|c|}{ GI } & \multicolumn{2}{|c|}{ GL } \\
\hline & $\begin{array}{c}\text { Crude } \\
(95 \% \mathrm{CI})\end{array}$ & $\begin{array}{l}\text { Adjusted } \\
(95 \% \mathrm{CI})^{*}\end{array}$ & $\begin{array}{c}\text { Crude } \\
(95 \% \mathrm{CI})\end{array}$ & $\begin{array}{l}\text { Adjusted } \\
(95 \% \mathrm{CI})^{*}\end{array}$ \\
\hline ICC of repeated FFQs & $0.82(0.77,0.86)$ & $0.78(0.71,0.83)$ & $0.86(0.82,0.90)$ & $0.74(0.67,0.80)$ \\
\hline Pearson correlation $^{+}$ & $0.69(0.58,0.77)$ & $0.63(0.51,0.73)$ & $0.79(0.71,0.85)$ & $0.63(0.51,0.73)$ \\
\hline Spearman correlation $^{+}$ & $0.67(0.56,0.76)$ & $0.62(0.49,0.72)$ & $0.83(0.76,0.88)$ & $0.60(0.48,0.71)$ \\
\hline Weighted kappa ${ }^{+, \neq}$ & $0.42(0.31,0.53)$ & $0.40(0.29,0.51)$ & $0.53(0.43,0.63)$ & $0.41(0.30,0.52)$ \\
\hline
\end{tabular}

Pearson correlation coefficients between the first FFQ measurement and the average of 24HDRs were 0.69 for GI and 0.79 for GL before adjusting for energy intake, and 0.63 for both GI and GL after the adjustment for total energy intake. Weighted kappa values between the first FFQ and the average of 24HDRs (in quintiles) were 0.42 for GI and 0.53 for GL. After the adjustment for energy intake, these values changed to 0.40 and 0.41 respectively.

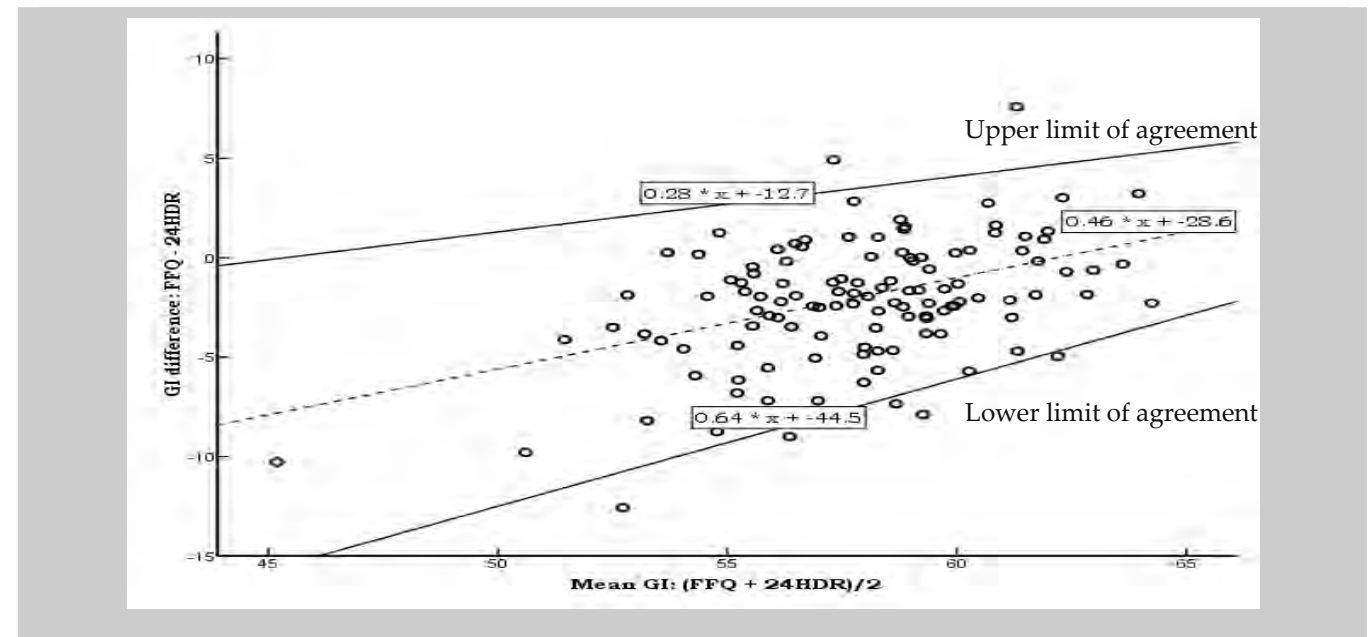

Figure 4-1. Bland-Altman plot of GI from the first FFQ and weighted average of 12 24HDRs $(n=121)$. 
There was a systematic underreporting in the FFQ for both GI (mean difference 2.2) and GL (mean difference 3.0) as compared to the average of 24HDRs (Table 4-1). A positive association was found between the difference and the mean of GI $(\beta=0.46$, 95\% confidence interval (CI): 0.28, 0.63) (Figure 4-1), suggesting the presence of proportional bias in the FFQ: underreporting at lower GI level and over-reporting at higher GI level. No such association was found for GL $(\beta=0.06,95 \%$ CI: $-0.11,0.24)$ (Figure 4-2), although fairly wide limits of agreement were observed (-43.7 to 37.7). Logarithmic transformation, as proposed by Bland and Altman, ${ }^{14}$ did not remove the proportional bias in GI (data not shown).

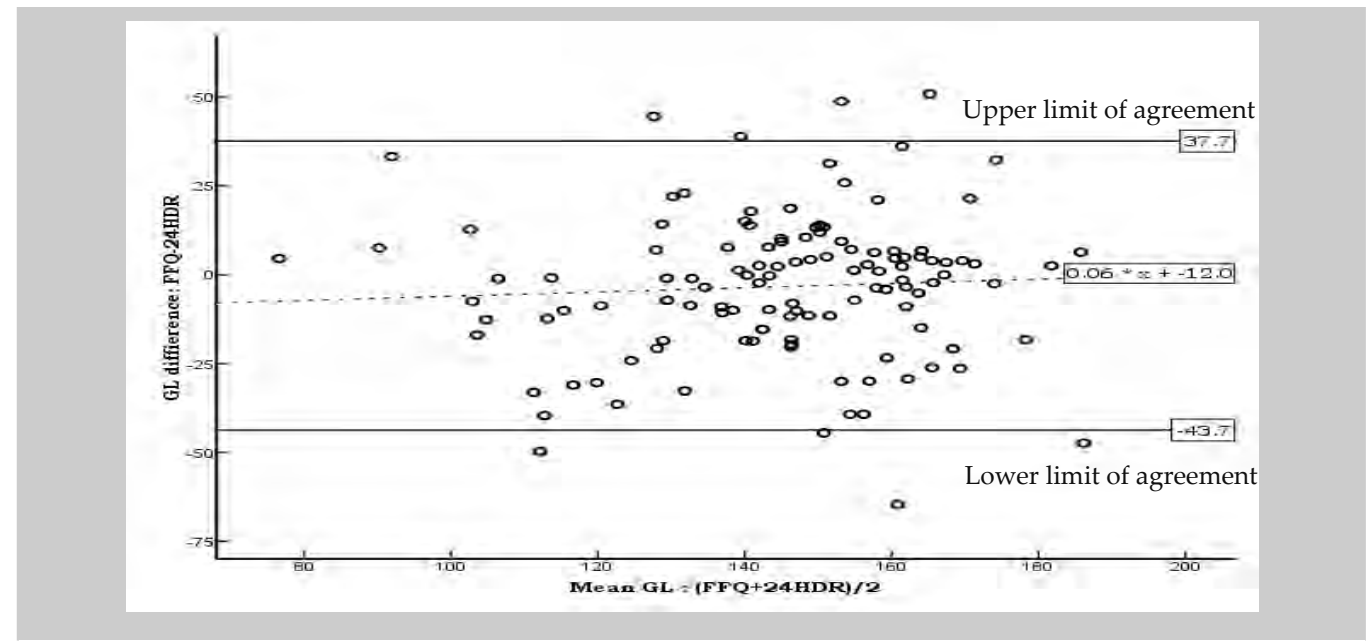

Figure 4-2. Bland-Altman plot of GL from the first FFQ and weighted average of 12 24HDRs $(n=121)$.

\section{Discussion}

We found good reproducibility and relative validity of GI and GL assessed by the FFQ used in the Dutch EPIC cohorts.

To our knowledge, only three dietary questionnaires have been evaluated for their validity of GI and GL measurements, ${ }^{15-17}$ of which the Swedish FFQ ${ }^{16}$ and the Japanese dietary history questionnaire ${ }^{17}$ have also been evaluated for their reproducibility. The reproducibility of the current FFQ was higher than those found in these two studies. Reproducibility of questionnaires could be influenced by the time interval between administrations. Too long, real change in eating habits may occur which may underestimate the reproducibility. On the other hand, if the interval is too short, participants may remember the previous questionnaire and therefore respond with the same answers, thus overestimate the reproducibility. Compared with the two previous studies, the time interval of the current study (6 months) is shorter than the study from Levitan et al (1 year) ${ }^{16}$ but longer than the administration time of Japanese dietary history questionnaire ( 3 months). ${ }^{17}$ Therefore, 
most likely the time interval is not the reason for the higher reproducibility observed in the present study.

The validity of dietary assessment methods can be tested with different statistical tools depending on the intended use. The Bland-Altman method has been suggested as the best method for assessing the agreement between two measurement methods. ${ }^{18}$ In our case, the plots indicate a systematic underestimation of GL by the FFQ, whereas for GI there is an underestimation at the lower GI level and an overestimation at the higher GI level. However, given that FFQs are most of the time used in association studies to rank individuals according to their intake level rather than for measuring the absolute level of intake, calculating correlation coefficients and weighted kappa statistics are more appropriate. ${ }^{19}$ The validity of GI and GL in this study, as indicated by Pearson correlation coefficients, was similar as the results from three previous studies.15-17 Only one of these three studies used weighted kappa values to assess the agreement between the modified Willett FFQ and three 4-day weighted food records. ${ }^{15}$ Values from our current study were higher for GL ( 0.41 vs. $0.30)$ but lower for GI ( 0.40 vs. 0.53$)$ as compared with their findings. It has been suggested that correlation coefficients of 0.5 or higher indicate that the FFQ has sufficient ability to rank individuals according to their nutrient intake as continuous variable, while for categorical variables, weighted kappa values are recommended to be above 0.4 in order to draw valid conclusions. ${ }^{19}$

In conclusion, the findings of the current study support the use of this FFQ in epidemiological studies in which associations of GI and GL, either as continuous or categorical variables, with disease risks are under investigation. However, the proportional bias should be taken into account when using this FFQ to assess absolute GI values.

\section{References}

1. Barclay AW, Petocz P, McMillan-Price J, et al. Glycemic index, glycemic load, and chronic disease risk--a meta-analysis of observational studies. Am J Clin Nutr. 2008;87(3):627-637.

2. Cust AE, Slimani N, Kaaks R, et al. Dietary carbohydrates, glycemic index, glycemic load, and endometrial cancer risk within the European Prospective Investigation into Cancer and Nutrition cohort. Am J Epidemiol. 2007;166(8):912-923.

3. Du H, van der A DL, van Bakel MM, et al. Glycemic index and glycemic load in relation to food and nutrient intake and metabolic risk factors in a Dutch population. Am J Clin Nutr. 2008;87(3):655-661.

4. Liu S, Manson JE, Stampfer MJ, et al. Dietary glycemic load assessed by food-frequency questionnaire in relation to plasma high-density-lipoprotein cholesterol and fasting plasma triacylglycerols in postmenopausal women. Am J Clin Nutr. 2001;73(3):560-566.

5. Silvera SA, Jain M, Howe GR, et al. Glycaemic index, glycaemic load and ovarian cancer risk: a prospective cohort study. Public Health Nutr. 2007;10(10):1076-1081.

6. Ocke MC, Bueno-de-Mesquita HB, Goddijn HE, et al. The Dutch EPIC food frequency questionnaire. I. Description of the questionnaire, and relative validity and reproducibility for food groups. Int J Epidemiol. 1997;26 Suppl 1:S37-48.

7. Ocke MC, Bueno-de-Mesquita HB, Pols MA, et al. The Dutch EPIC food frequency questionnaire. II. Relative validity and reproducibility for nutrients. Int J Epidemiol. 1997;26 Suppl 1:S49-58. 
8. NEVO Foundation (Stichting Nederlands Voedingsstoffenbestand). Dutch Food Composition Table (Nederlands voedingsstoffenbestand, NEVO Table). Dutch Nutrition Center (Voedingscentrum/Voorlichtingsbureau voor de Voeding), Den Haag; 1996.

9. van Bakel MM, Slimani N, Feskens EJ, et al. Methodological challenges in the application of the glycemic index in epidemiological studies using data from the European Prospective Investigation into Cancer and Nutrition. J Nutr. 2009;139(3):568-575.

10. Foster-Powell K, Holt SH, Brand-Miller JC. International table of glycemic index and glycemic load values: 2002. Am J Clin Nutr. 2002;76(1):5-56.

11. Henry CJ, Lightowler HJ, Strik CM, et al. Glycaemic index and glycaemic load values of commercially available products in the UK. Br J Nutr. 2005;94(6):922-930.

12. The official website of the glycemic index and GI database www.glycemicindex.com. Human Nutrition Unit, University of Sydney.

13. Willett WC. Anthropometric measures and body composition. Nutritional Epidemiology. 2nd edition. New York: Oxford University Press; 1998.

14. Bland JM, Altman DG. Measurement error proportional to the mean. Bmj. 1996;313(7049):106.

15. Barclay AW, Flood VM, Brand-Miller JC, et al. Validity of carbohydrate, glycaemic index and glycaemic load data obtained using a semi-quantitative food-frequency questionnaire. Public Health Nutr. 2008;11(6):573-580.

16. Levitan EB, Westgren CW, Liu S, et al. Reproducibility and validity of dietary glycemic index, dietary glycemic load, and total carbohydrate intake in 141 Swedish men. Am J Clin Nutr. 2007;85(2):548-553.

17. Murakami K, Sasaki S, Takahashi $Y$, et al. Reproducibility and relative validity of dietary glycaemic index and load assessed with a self-administered diet-history questionnaire in Japanese adults. $\mathrm{Br} J$ Nutr. 2008;99(3):639-648.

18. Bland JM, Altman DG. Statistical methods for assessing agreement between two methods of clinical measurement. Lancet. 1986;1(8476):307-310.

19. Masson LF, McNeill G, Tomany JO, et al. Statistical approaches for assessing the relative validity of a food-frequency questionnaire: use of correlation coefficients and the kappa statistic. Public Health Nutr. 2003;6(3):313-321. 



\title{
5 \\ Dietary glycemic index, glycemic load and subsequent changes of weight and waist circumference in European men and women
}

\author{
H. Du, D. L. van der A, M. M.E. van Bakel, N. Slimani, N. G. Forouhi, \\ N. J. Wareham,J. Halkjer, A. Tjønneland, M. Uhre Jakobsen, \\ K. Overvad, M. B. Schulze, B. Buijsse, H. Boeing, D. Palli, G. Masala, \\ T. I.A. Sørensen, W. H.M.Saris, E. J.M. Feskens.
}

Int J Obes. Epublished 25 August 2009.

\begin{abstract}
Objectives: To investigate whether dietary glycemic index (GI) and glycemic load (GL) were associated with subsequent weight and waist circumference change.

Design: Population-based prospective cohort study.

Setting: Five European countries, which are Denmark, Germany, Italy, The Netherlands, and the UK.

Participants: 89,432 participants, aged 20-78 years (mean $=53$ years) at baseline and followed for 1.9-12.5 years (mean $=6.5$ years). All participants were free of selfreported cancer, cardiovascular diseases and diabetes at baseline.

Methods: GI and GL were calculated based on dietary intake assessed by food frequency questionnaires and by using a GI table developed for this study with published GI values as the main sources. Anthropometric data were collected both at baseline and at the end of follow-up. Multiple linear regression analyses were conducted in each centre and random-effect meta-analyses were used to combine the effects. Adjustment was made for baseline anthropometrics, demographic and lifestyle factors, follow-up duration, and other dietary factors.

Results: Mean GI and GL were 57 and 134 respectively. Associations of GI and GL with subsequent changes of weight and waist circumference were heterogeneous across centers. Overall, per 10-unit GI higher, weight increased by $34 \mathrm{~g} /$ year [ $95 \%$ confidence interval (CI): - 47, 115] and waist circumference increased by $0.19 \mathrm{~cm} /$ year [95\% CI: 0.11, 0.27]. Per 50-unit GL higher, weight increased by $10 \mathrm{~g} /$ year $[-65,85]$, waist circumference increased by $0.06 \mathrm{~cm} /$ year $[-0.01,0.13]$.
\end{abstract}


Conclusions: Our findings do not support an effect of GI or GL on weight change. The positively significant association between GI, not GL, and subsequent gain in waist circumference may imply a beneficial role of lower GI diets in the prevention of abdominal obesity. However, further studies are needed to confirm this finding given the small effect observed in this study.

Keywords: glycemic index, glycemic load, weight change, waist circumference change, cohort.

\section{Introduction}

With the increase of overweight and obesity worldwide and the growing burden of obesity-related chronic diseases, there is an increasing interest in identifying modifiable determinants of body weight gain. Glycemic index (GI) has received considerable attention in this respect. The concept of GI, developed in the early 1980s by Jenkins and co-workers, is a quantitative measure of carbohydrate quality based on the blood glucose response after consumption. ${ }^{1}$ Glycemic load (GL) was defined later to capture the entire blood glucose-raising potential of dietary carbohydrates and it is calculated as the product of GI and total available carbohydrates. ${ }^{2}$ It has been suggested that low GI or GL diets can help to prevent body weight gain and stimulate weight loss. ${ }^{3}$ This is because the mild blood glucose and insulin response following a low GI or GL diet consumption could stimulate a higher satiation and satiety, thus leading to a decrease in energy intake; ${ }^{4}$ regulate fuel partitioning in the way of reducing fat storage; $;$ and limit the decrease of resting metabolic rate under energy restriction. 6,7

A recent Cochrane Review of six randomized controlled trials (RCTs) has concluded that over the intervention period of five weeks to six months, low GI and low GL diets are more effective in promoting body fat loss ( 1 $\mathrm{kg}$ more) than the comparison diets. ${ }^{8}$ However, this conclusion has not been consistently confirmed by RCTs published thereafter.9-12 Short duration, difficulties in adhering to the prescribed diets, and a high drop-out rate are well known drawbacks of clinical intervention studies. Furthermore, dietary factors promoting weight loss among obese individuals may not be appropriate to prevent weight gain in a long term. ${ }^{13}$ Given that weight gain usually develops slowly over many years, it is difficult, if not impossible, to conduct RCTs investigating the effects of dietary factors on preventing weight or waist circumference gain. Therefore, large prospective cohort studies are important in exploring dietary determinants of longterm weight and waist circumference gain. ${ }^{14}$ In the analysis of data from the SEASONS study in the US, GI, but not GL, has been positively associated with change in body mass index (BMI). ${ }^{15}$ In the Danish arm of the Monitoring Trends and Determinants in Cardiovascular Disease study, low GI diets have been associated with a lower weight and waist circumference gain in women but not in men. During the 6 year follow-up, women who had 10-unit higher GI have gained $1.3 \mathrm{~kg}$ more weight and $2 \mathrm{~cm}$ more waist circumference than those with lower GI.16 
This prospective cohort study was conducted with the objective of examining the association of dietary GI and GL with subsequent changes of weight and waist circumference. With data from five European countries, this study also provided a good opportunity to test the robustness of findings across populations.

\section{Methods}

Participants

This study is a part of the DiOGenes project (acronym for "Diet, Obesity and Genes") which is a pan-European program targeting on obesity. Participants came from eight cities or counties within five European countries, which are Florence (Italy), Norfolk (UK), Amsterdam, Maastricht and Doetinchem (The Netherlands), Potsdam (Germany), Copenhagen and Aarhus (Denmark), participating in the European Prospective Investigation into Cancer and Nutrition (EPIC) study. Detailed information on the study population and data collection has been described elsewhere. ${ }^{17}$ Of the 146,543 men and women who took part in the baseline examination of EPIC during 1992-1998, 102,346 (69.8\%) participated in the follow-up examination of DiOGenes during 1998-2005. The exclusion criteria for the current study were: pregnancy at baseline or follow-up $(n=133)$, missing information on diet, anthropometric data or follow-up duration $(n=2,135)$, the ratio of energy intake to estimated basal metabolic rate (EI:BMR) within the top or bottom $1 \%$ of the total EPIC population $(n=1,803)$, unrealistic anthropometric measurements $(n=331)$ and self-reported chronic diseases including cancer, cardiovascular diseases (CVD) and diabetes at baseline $(n=8,512)$. In total, 89,432 participants, 37,125 $(42 \%)$ men and $52,307(58 \%)$ women, were included in the data analyses.

\section{Dietary assessment}

Country-specific food frequency questionnaires (FFQs) were self-administered at baseline. All FFQs are validated for total energy, total carbohydrate intake, dietary fiber, and main carbohydrate containing foods. ${ }^{18-24}$ Energy and nutrient intakes were calculated using country-specific food composition tables. ${ }^{17}$ Since GI values of foods were largely absent in food composition tables, a GI-database was specially developed, using mainly published information, under the joint efforts of the EPIC and the DiOGenes projects. ${ }^{25}$ Dietary GI was calculated as the weighted average of GI values (GI of glucose $=100$ ) of foods consumed per day and GL was calculated as the product of GI multiplied with total available carbohydrates intake (g/day), divided by $100.26 \mathrm{GI}$ and GL measured by the Dutch FFQ have been validated against multiple 24-hour recalls $(r=0.63) .{ }^{27}$ To improve the comparability of dietary data collected using different FFQs and to adjust for measurement errors, a linear calibration was performed using a single 24-hour dietary recall from a stratified random sample of the entire EPIC study populations as reference method. ${ }^{28,} 29$ Among the 89,432 participants included in the current study, 6,790 participants also had 24-hour dietary recall data available. These 24-hour dietary recall data were 
collected using a software program (EPIC-SOFT, IARC, Lyon, France) specifically designed to standardize the dietary measurements across European populations. ${ }^{30}$ Nutrient intake in the 24-hour recall data were standardized based on the standardized nutrient database developed within the EPIC study (ENDB). ${ }^{31}$ Genderand centre-specific calibration models were built with 24-hour dietary recall measurements as dependent variables and FFQ measurements as independent variables. Age, body weight, height, and season in which the FFQ was administered were adjusted for. Energy density was calculated as energy (kcal) from foods divided by the weights $(\mathrm{g})$ of these foods. Drinks were not included in the calculation. ${ }^{32}$ Under-reporting of energy intake was defined as EI: BMR $<1.1 .{ }^{33} \mathrm{BMR}$ was estimated using the Harris-Benedict equation. ${ }^{34}$

\section{Anthropometric measurements}

Weight and waist circumference were collected at baseline and at the end of follow-up. At baseline, all participants were measured for weight, height and waist circumference. Methods used have been described in detail previously. ${ }^{35}$ In brief, body weight and height were measured when participants wear light clothes and no shoes. Waist circumference was measured either at the midway between the lowest rib and the iliac crest (NL-AmMa, NL-Doe, and GER-Pot) or the narrowest torso circumference (the other centers). At follow-up, participants in Norfolk (UK) and Doetinchem (NL) were measured by trained technicians using the same protocols as baseline, while others provided self-reported data. For the latter, guidance was provided to measure waist circumference as at baseline, except for DK-CopAa where participants were guided to measure their waist circumference at the umbilicus (the reason of changing the site of measurement was to simplify the measurement instructions for participants). Annual change in weight (g/year) and waist circumference ( $\mathrm{cm} /$ year) were calculated as follow-up values minus baseline values and divided by follow-up duration in years. Due to the differences in methods used to collect anthropometric data at follow-up and the length of follow-up, participants from Doetinchem (NL) were treated separately from those from Amsterdam and Maastricht (NL), while participants from Copenhagen and Aarhus (DK) were combined because no such differences between these two groups existed. Thus, six study centers were identified, namely Florence (IT-Flo, 2,041 men and 7,256 women), Norfolk (UK-Nor, 5,594 men and 7,214 women), Amsterdam-Maastricht (NL-AmMa, 2,996 men and 3,915 women), Doetinchem (NL-Doe, 2,009 men and 2,191 women), Potsdam (GER-Pot, 6,214 men and 10,093 women) and Copenhagen-Aarhus (DKCopAa, 18,271 men and 21,638 women).

\section{Other covariates}

Information on lifestyle was collected via self-administered questionnaires. Questions covered age, gender, physical activity, education level, smoking, menopausal status, and use of hormone replace therapy (HRT). Information on 
health status (cancer, CVD, and diabetes) was collected using either questionnaires or disease registries. Physical activity level was indexed into five categories (inactive, moderately inactive, moderately active, active, or unknown) based on occupational and recreational activities. ${ }^{17}$ Education level was inquired as the highest level of school achieved and participants were classified into either primary school and less, technical-professional school, secondary school, university degree, or unknown. Smoking information was also available at follow-up. With baseline smoking information together, it classified participants into one of the following five categories: stable smoking, start smoking, quit smoking, not smoking, or unknown.

\section{Statistical methods}

Characteristics of study participants are given for each quintile of dietary GI, using means (with overall SDs) or frequencies where appropriate. A linear trend for characteristics across quintiles was tested by linear regression (continuous variables) or by the Cochrane-Armitage trend test (categorical variables).

The association of GI and GL with annual change in weight and waist circumference was investigated using multiple linear regression analyses. Centrestratified analyses were performed first, and random-effect meta-analyses were used to evaluate heterogeneity $\left(I^{2}\right)$ across study centers and to obtain pooled estimates of the associations. Analyses were adjusted for baseline age (years), gender, weight (kg), height $(\mathrm{cm})$ and waist circumference $(\mathrm{cm}$, for waist circumference change analyses only), smoking, physical activity, education, follow-up duration (years), and alcohol intake (non-drinker, 0.1-4.9g/day, 4.9-15 g/day, 15-30 g/day, 30-60 g/day, > 60 g/day). In women, analyses were also adjusted for menopausal status (postmenopausal yes/no) and HRT use (yes/no, or unknown). The analyses for GI were additionally adjusted for the intake of dietary fiber, fat, protein and total available carbohydrates and the analyses for GL were additionally adjusted for the intake of total energy, fiber and protein. All dietary variables included in the analyses were calibrated and were adjusted for total energy intake using the residual method. ${ }^{36}$ To investigate whether the effects of GI and GL are independent of the chemical composition of dietary carbohydrates, analyses were run with and without adjustment for simple to complex carbohydrate ratio.

Interactions of GI and GL with baseline age, gender, baseline BMI, follow-up duration, baseline waist circumference (for waist circumference change analyses only), smoking, and EI:BMR were investigated by introducing product terms into the models. A two-sided $P<0.05$ was considered statistically significant in the analyses of main effects, whereas $P<0.01$ in at least three of the six study centers was considered relevant when testing for interaction.

Several sensitivity analyses were performed for the main analyses, including using un-calibrated dietary variables; using anthropometric variables corrected for clothing differences and self-reporting using methods previously developed in the EPIC study ${ }^{35}$; excluding those participants who self-reported onset of cancer, type 2 
Table 5-1. Characteristics of study participants across quintiles of glycemic index (GI).

\begin{tabular}{|c|c|c|c|c|c|c|}
\hline Characteristics*,+ & Overall & Q1 & Q2 & Q3 & Q4 & Q5 \\
\hline Glycemic index (GI) & $57 \pm 2.6$ & 53 & 56 & 57 & 58 & 60 \\
\hline Baseline age, yrs & $53 \pm 8.6$ & 51 & 54 & 54 & 55 & 53 \\
\hline Gender, \% men & 42 & 22 & 32 & 37 & 48 & 68 \\
\hline Follow-up length, yrs & $6.5 \pm 2.2$ & 7.9 & 6.7 & 6.1 & 5.6 & 6.0 \\
\hline Baseline weight, $k g$ & $73.4 \pm 13.5$ & 71.3 & 72.1 & 72.6 & 74.4 & 76.6 \\
\hline Baseline BMI, $\mathrm{kg} / \mathrm{m}^{2}$ & $25.7 \pm 3.8$ & 25.7 & 25.6 & 25.7 & 25.8 & 25.9 \\
\hline Overweight, \% & 41 & 38 & 40 & 41 & 42 & 43 \\
\hline Obesity, \% & 12 & 13 & 12 & 12 & 12 & 12 \\
\hline Baseline waist circumference, $\mathrm{cm}$ & $86.2 \pm 12.3$ & 83.2 & 84.5 & 85.5 & 87.6 & 90.1 \\
\hline Total energy intake, kcal/day & $2,200 \pm 460$ & 2,047 & 2,123 & 2,156 & 2,249 & 2,426 \\
\hline Energy density, $\mathrm{kcal} / \mathrm{g}$ & $1.73 \pm 0.27$ & 1.55 & 1.63 & 1.70 & 1.81 & 1.96 \\
\hline Fat, $E n \%$ & $35.6 \pm 3.6$ & 36.7 & 34.9 & 34.5 & 35.4 & 36.6 \\
\hline Protein, $E n \%$ & $15.1 \pm 1.4$ & 14.5 & 15.5 & 15.6 & 15.2 & 14.8 \\
\hline Carbohydrates, En \% & $43.1 \pm 4.4$ & 43.8 & 43.7 & 43.9 & 43.0 & 40.9 \\
\hline Polysaccharides, En \% & $21.8 \pm 3.9$ & 19.5 & 22.2 & 22.9 & 22.2 & 22.0 \\
\hline Mono-disaccharides, En \% & $19.9 \pm 4.1$ & 22.9 & 20.1 & 19.7 & 19.4 & 17.5 \\
\hline Glycemic load & $134 \pm 29$ & 119 & 128 & 134 & 140 & 149 \\
\hline Fiber, g/day & $22.8 \pm 5.2$ & 21.8 & 22.4 & 22.6 & 23.1 & 24.2 \\
\hline \multicolumn{7}{|l|}{ Smoking status $¥ \S, \%$} \\
\hline Stable smoking & 19 & 14 & 16 & 17 & 20 & 29 \\
\hline Start smoking & 2 & 2 & 2 & 2 & 2 & 2 \\
\hline Quit smoking & 7 & 6 & 6 & 6 & 6 & 9 \\
\hline Not smoking & 72 & 79 & 76 & 75 & 72 & 60 \\
\hline \multicolumn{7}{|l|}{ Education $\neq, \|, \%$} \\
\hline Primary school or lower & 27 & 19 & 27 & 30 & 29 & 32 \\
\hline Technical/professional school & 36 & 37 & 32 & 34 & 39 & 39 \\
\hline Secondary school & 13 & 11 & 16 & 16 & 13 & 11 \\
\hline University degree or higher & 23 & 33 & 25 & 21 & 20 & 19 \\
\hline \multicolumn{7}{|l|}{ Physical activity $\ddagger$,II, \% } \\
\hline Inactive & 16 & 18 & 18 & 17 & 16 & 13 \\
\hline Moderately inactive & 33 & 37 & 35 & 33 & 31 & 28 \\
\hline Moderately active & 24 & 24 & 23 & 24 & 23 & 24 \\
\hline Active & 27 & 20 & 24 & 27 & 29 & 35 \\
\hline Post-menopausal women, \% & 57 & 46 & 59 & 62 & 63 & 62 \\
\hline Hormone-use women $\$, \%$ & 22 & 24 & 20 & 21 & 22 & 23 \\
\hline \multicolumn{7}{|c|}{$\begin{array}{l}\text { * Values presented are mean }( \pm \mathrm{SD}) \text { or percentages. } \\
{ }^{+} \text {A linear trend for characteristics across quintiles was tested by linear regression (continuous variables) or by } \\
\text { the Cochrane-Armitage trend test (categorical variables). } P \text { for trend }<0.001 \text { for all characteristics except for } \\
\text { obesity }(P=0.11) \text { and hormone user }(P=0.08) \text {. } \\
\ddagger \text { Percentages are based on those participants with available data on that variable and may not sum to } 100 \% \text { due } \\
\text { to rounding. } \$ 1,440 \text { participants with missing values. } \| 1,579 \text { participants with missing values. } \\
\text { I } 3,319 \text { participants with missing values. } \$ 1,273 \text { participants with missing values. }\end{array}$} \\
\hline
\end{tabular}


diabetes or CVD during follow-up. Except for the random-effect meta-analyses, which were conducted using STATA 8.2 (StataCorp, Texas, USA), all statistical analyses were performed using SAS 9.1 (SAS, Institute, Cary, NC).

\section{Results}

Mean age at baseline was 53 years (range: 20-78 years) and participants were followed for a mean of 6.5 years (range: $1.9-12.5$ years). At baseline, $51 \%$ of men and $34 \%$ of women were overweight $\left(30 \mathrm{~kg} / \mathrm{m}^{2}>\mathrm{BMI} \geq 25 \mathrm{~kg} / \mathrm{m}^{2}\right)$. Furthermore, $12 \%$ of the participants were obese (BMI $\geq 30 \mathrm{~kg} / \mathrm{m}^{2}$ ) and $21 \%$ had abdominal obesity (waist circumference $\geq 102 \mathrm{~cm}$ for men or $\geq 88 \mathrm{~cm}$ for women).

Mean (SD) GI was 58 (2.5) in men and 56 (2.4) in women; mean GL was 156 (26) in men and 118 (19) in women. Characteristics of study participants along quintiles of GI are presented in Table 5-1. Participants with higher GI were more often men, overweight and smokers, had a lower education level and were more physically active than those with lower GI. From the lowest to the highest GI quintile, the intake of total energy and dietary fiber and dietary energy density increased and the intake of mono-and disaccharides decreased. Participants in the higher GL quintile groups were more often men and smokers, had a higher education level and were more physically active. The intake of total energy, dietary fiber, fat and polysaccharides and dietary energy density increased with increasing levels of GL (Table 5-2). The characteristics of participants by study centre are presented in a supplementary table (S-Table 5-1).

GI was inversely associated with weight change in UK-Nor and NL-Doe, while positively in all other centers. Overall, a 10-unit GI difference was associated with an annual weight change of $34 \mathrm{~g} /$ year [ $95 \%$ confidence interval (CI): $-47,115]\left(I^{2}=83 \%, P\right.$ for heterogeneity $<0.001$ ) before adjusting for simple to complex carbohydrate ratio (Figure 5-1a). After adjusting, the overall effect of 10 unit GI on annual weight change was $84 \mathrm{~g} /$ year [95\% CI: $-5,172]\left(I^{2}=78 \%, P\right.$ for heterogeneity $\left.<0.001\right)$ (Figure 5-1b). GI was positively associated with waist circumference change in all study centers. The overall effect of 10-unit GI on an annual waist circumference change was $0.19 \mathrm{~cm} /$ year [95\% CI: 0.11, 0.27] $\left(I^{2}=72 \%, P\right.$ for heterogeneity $\left.=0.003\right)($ Figure 5-2a) and $0.26 \mathrm{~cm} /$ year [95\% CI: 0.20, 0.33] (Figure 5-2b) respectively before and after adjusting for simple to complex carbohydrate ratio. In addition, heterogeneity became non-significant $\left(I^{2}=36 \%, P\right.$ for heterogeneity $\left.=0.17\right)$ when the simple to complex carbohydrate ratio was additionally adjusted for.

The association of GL with both weight and waist circumference change was also heterogeneous across study centers $\left(I^{2}=83 \%\right.$ and $86 \%$ respectively, $P$ for heterogeneity $<0.001$ for both). Overall, a 50-unit GL difference was associated with an annual weight change of 10 g/year [95\% CI: -65, 85] (Figure 5-3) and an annual waist circumference change of $0.07 \mathrm{~cm} /$ year [95\% CI: -0.04, 0.18] (Figure 5-4). These associations did not materially change after additionally adjusting for the simple to complex carbohydrate ratio (data not shown). 
Table 5-2. Characteristics by gender and across quintiles of glycemic load (GL).

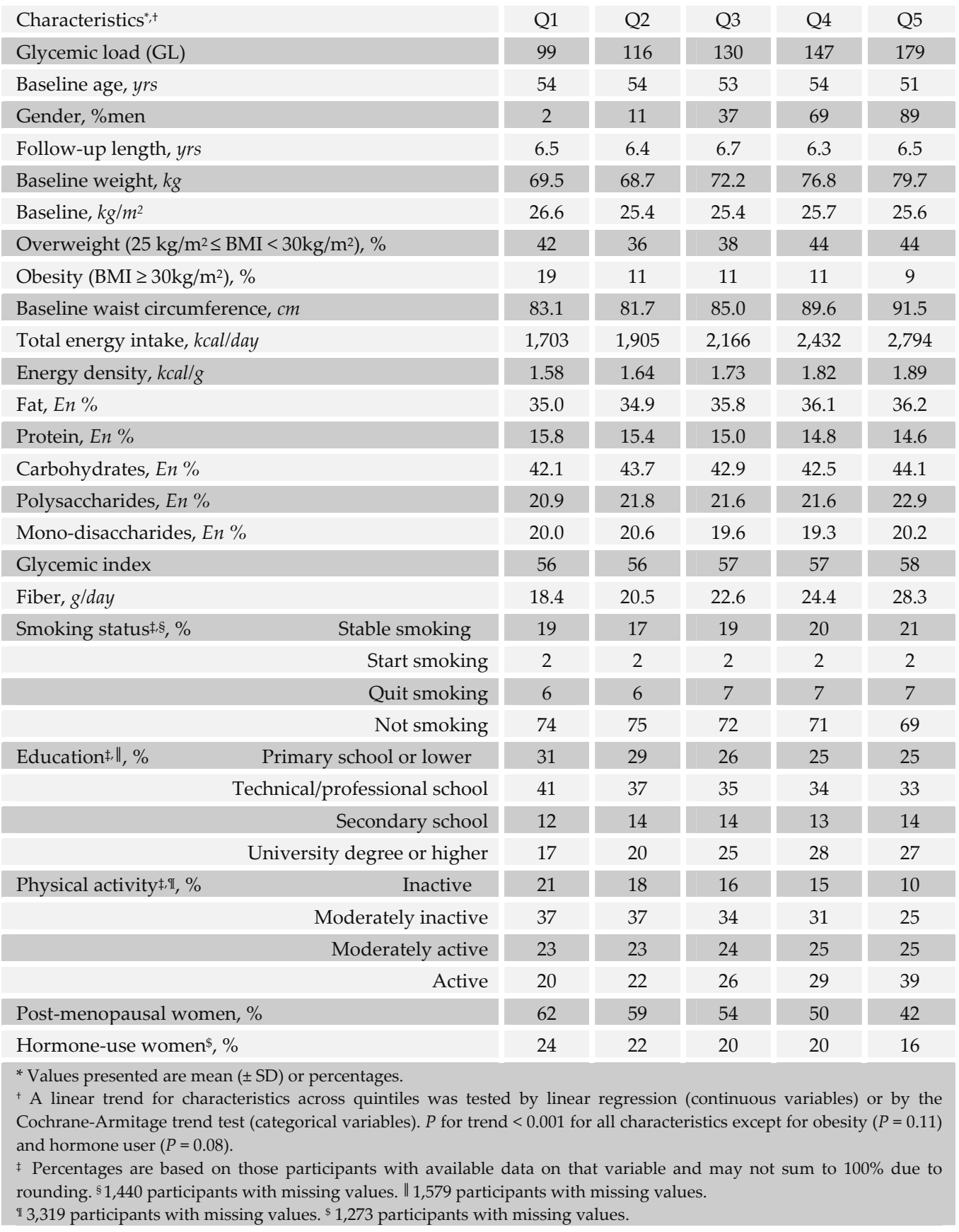

None of the potential effect modifiers under investigation fulfilled pre-defined criteria. Using un-calibrated dietary variables slightly attenuated the associations; using clothing- and self-report-corrected anthropometrics did not change the 
associations; excluding participants with self-reported onset of cancer, type 2 diabetes or CVD during follow-up slightly strengthen the associations. However, none of the above mentioned sensitivity analyses essentially changed the results (data not shown).

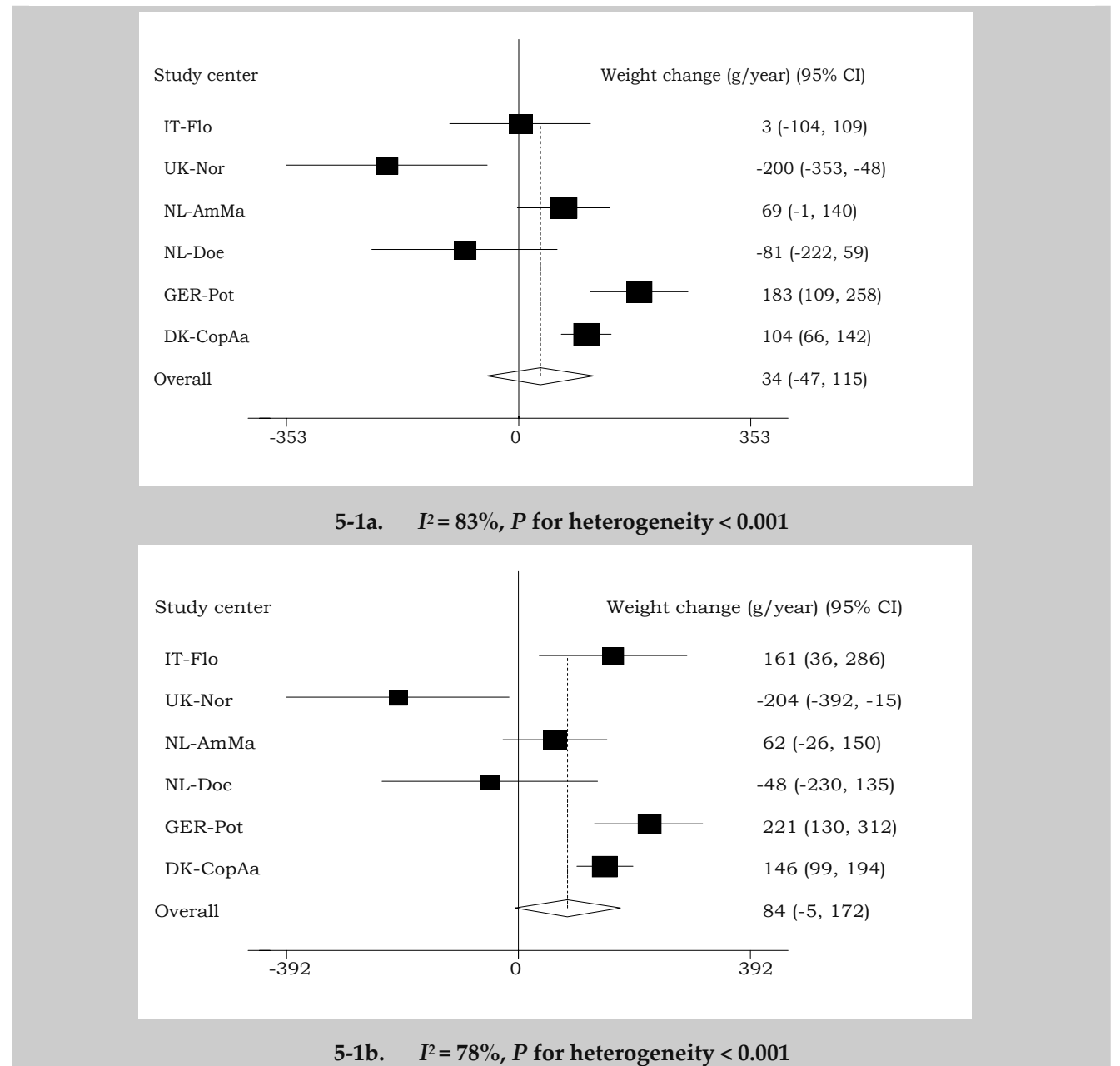

95\% CI: 95\% Confidence interval of regression coefficients. The overall estimate was based on random-effect model and indicates the weight change (g/year) for a 10-unit GI difference.

5-1a. Analyses were adjusted for follow-up duration, gender, baseline age, height and weight, smoking, physical activity, education, alcohol intake, the intake of fiber, fat, protein and total available carbohydrates, and, for women, menopausal status and use of hormone replace therapy.

5-1b. Analyses were additionally adjusted for simple to complex carbohydrate ratio.

\section{Figure 5-1. Association of glycemic index with annual weight change.}

\section{Discussion}


In this prospective cohort study with participants from five European countries, GI was not associated with body weight change but was positively associated with waist change. GL was not associated with either weight or waist change.

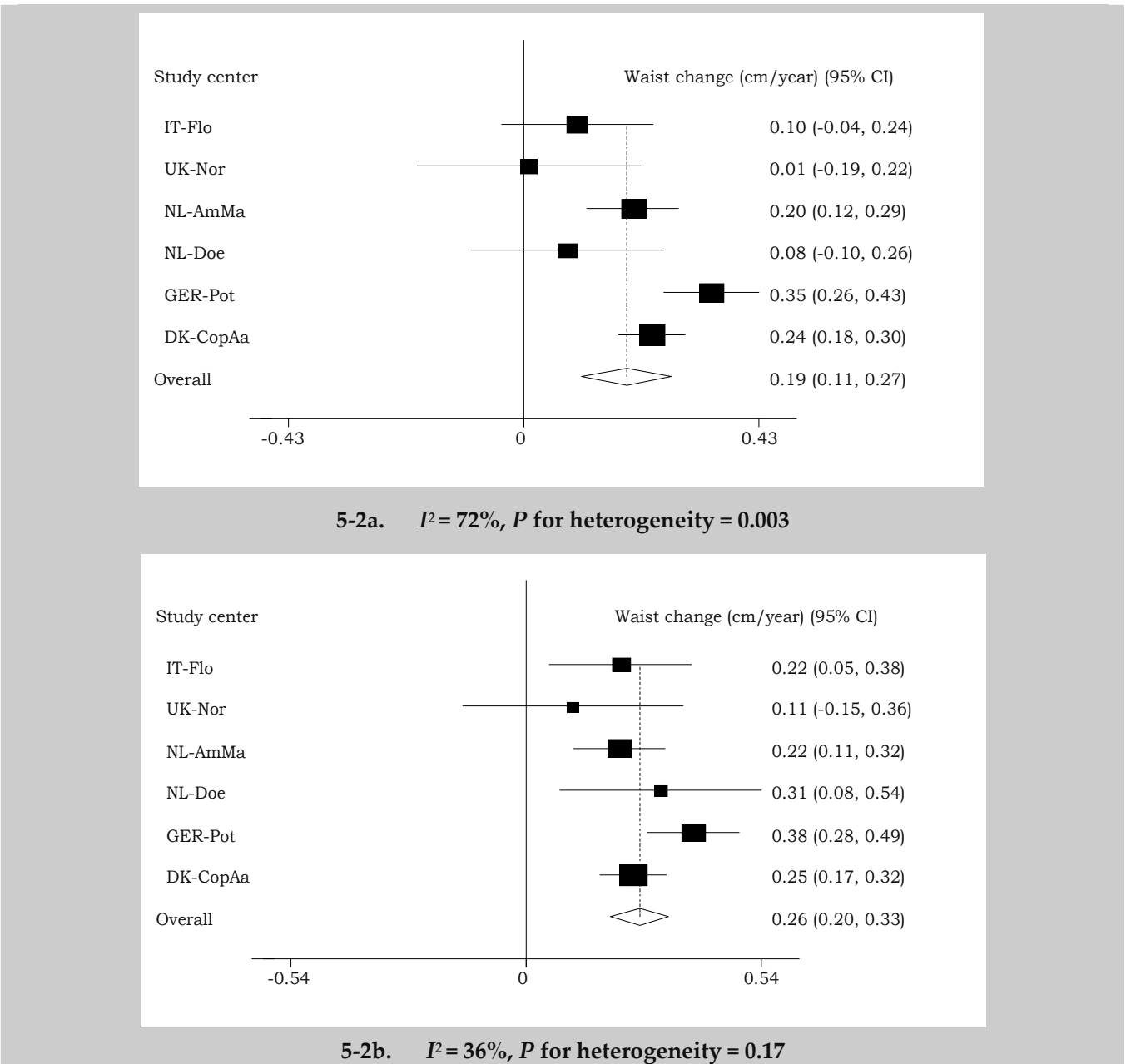

95\% CI: 95\% Confidence interval of regression coefficients. The overall estimate was based on random-effect model and indicates the waist circumference change (cm/year) for a 10-unit GI difference.

5-2a. Analyses were adjusted for follow-up duration, gender, baseline age, height, weight and waist circumference, smoking, physical activity, education, alcohol intake, the intake fiber, fat, protein and total available carbohydrates, and, for women, menopausal status and use of hormone replace therapy.

5-2b. Analyses were additionally adjusted for simple to complex carbohydrate ratio.

Figure 5-2. Association of glycemic index with annual change in waist circumference.

The main strengths of the current study include its large-scale and multi-centre prospective design, the availability of calibrated dietary variables based on 24-hour dietary recall data collected using a uniform system (EPIC-SOFT) ${ }^{29}$ and related standardized nutrient databases, ${ }^{31}$ and the centrally standardized covariate variables. 
Furthermore, we used the GI-database specifically developed for this study, which incorporated the best available knowledge in the field, especially for European population studies. ${ }^{25}$ However, using data from FFQs, which are not specifically designed for measuring GI and GL, and published GI values to assess dietary GI and GL might be a limitation because information on some factors influencing GI values, such as the food matrix of total meals, are sometimes missing in FFQs. ${ }^{25}$ Weight and waist circumference were self-reported instead of measured in four out of six study centers, potentially causing heterogeneity. In additional analyses, we corrected anthropometrics for clothing differences and self-reporting using methods previously developed in the EPIC study, ${ }^{35}$ but the results did not appreciably change. To investigate the influence of the site differences for waist circumference measurements, we have applied the regression equations developed in a previous study $^{37}$ to correct waist circumference at baseline and at follow-up. The associations between GI, GL and annual waist circumference change were essentially unchanged after the corrections. Another limitation is the residual confounding, which may flaw our results, although we have adjusted our analyses for a bunch of potential confounders.

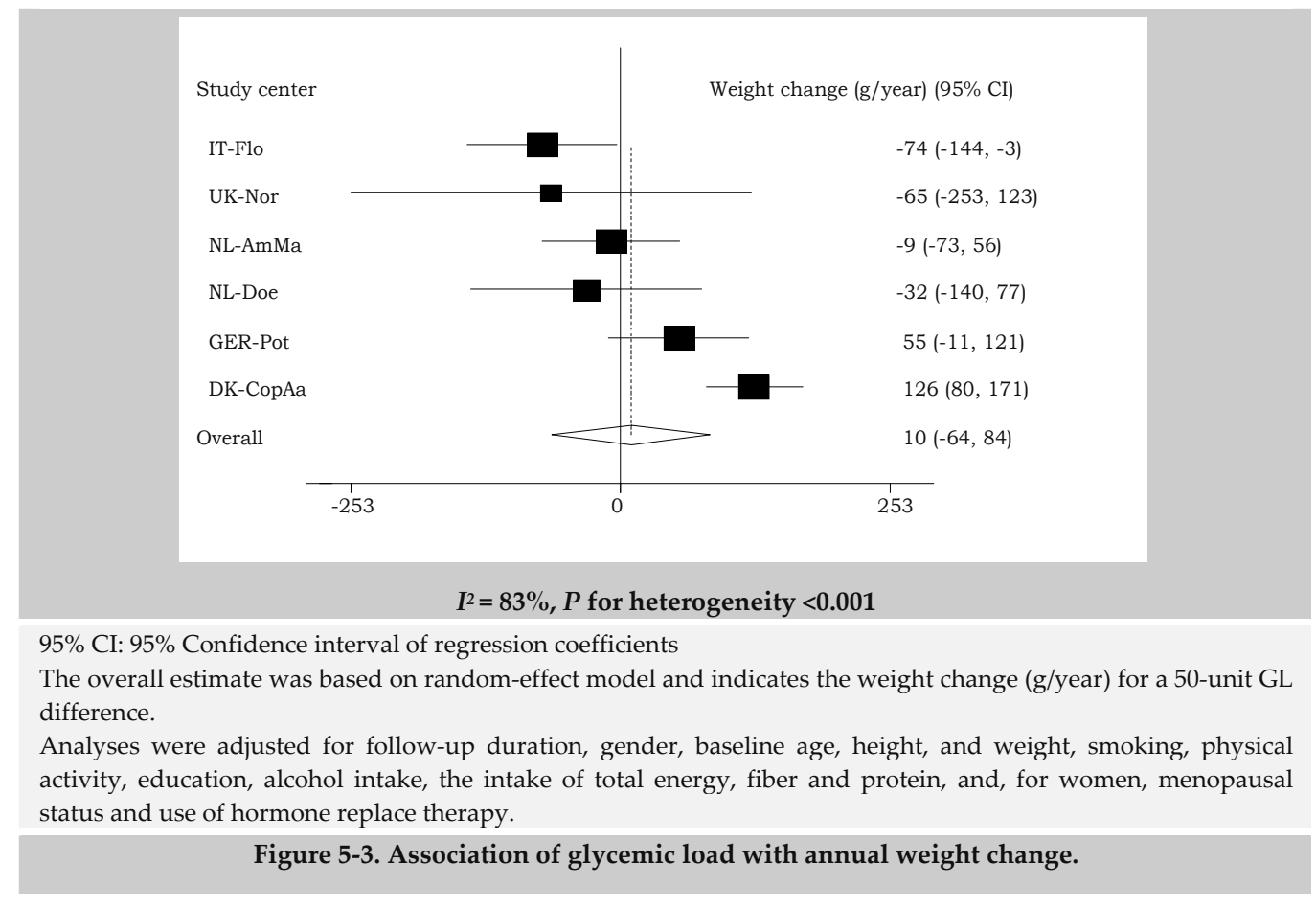

The GI was introduced to replace the traditional classification of simple and complex carbohydrates as a marker of blood glucose increase after consumption. Compared with low GI foods, carbohydrates from high GI foods are absorbed more 
rapidly, cause higher postprandial glucose and insulin response and affect nutrient partitioning in a way that encourages body fat storage.5,7 This is supported by the current findings because the potential benefits of low GI diets on weight and waist circumference change remained after adjusting for macronutrient composition and fiber intake. Notably, the effects of GI on weight and waist circumference change were not mediated by the simple to complex carbohydrate ratio and additional adjustment of this ratio even strengthened the associations (the association between GI and weight change tended to be borderline significant). This finding indicates that the GI is independent of the simple and complex carbohydrate composition and a low GI diet should not be achieved by replacing high GI starchy foods with low GI sugars. In other words, replace high GI starchy foods with low GI starchy food should be recommended.

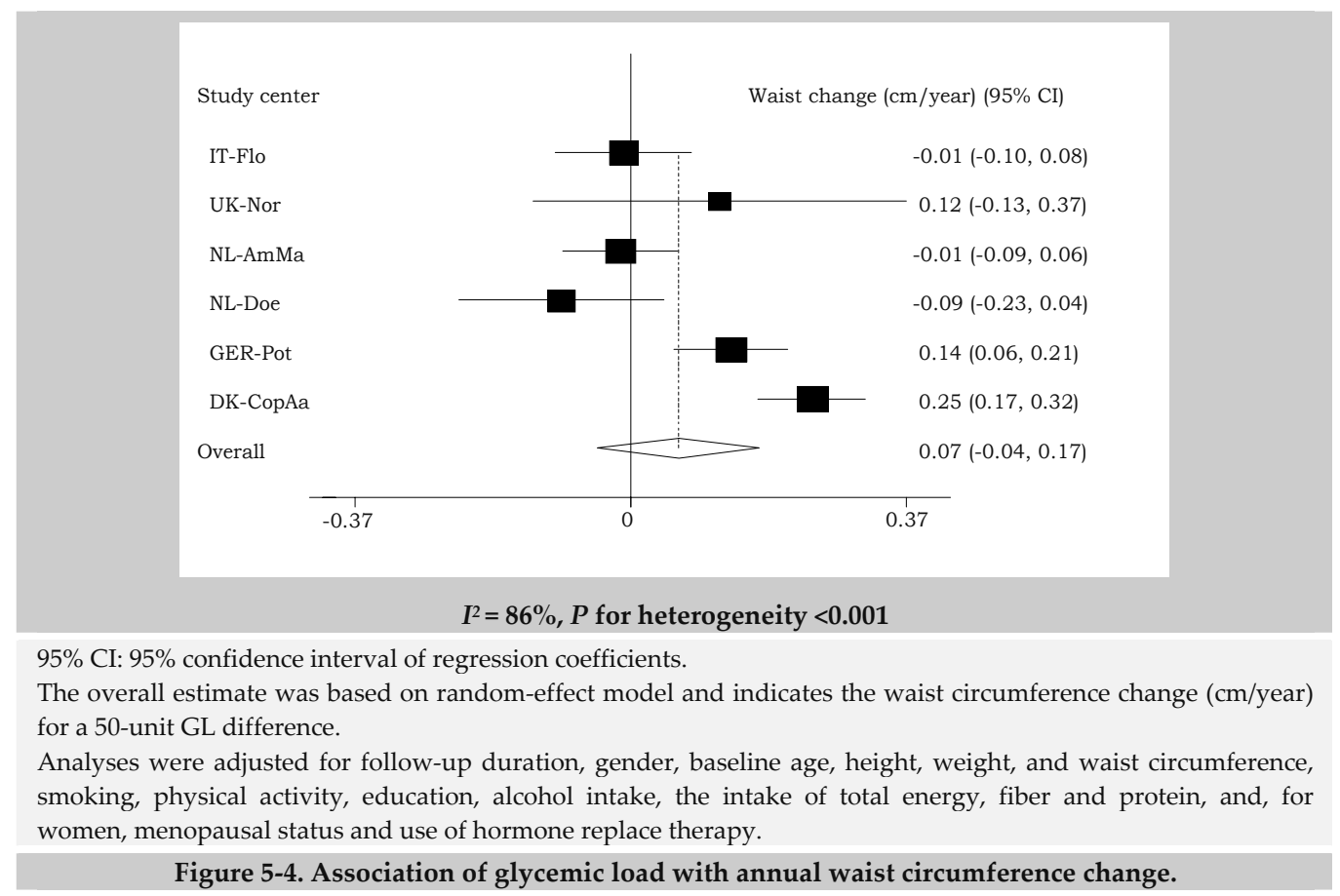

The role of dietary GI or GL on weight change is still an issue of debate. Whereas some clinical intervention studies observed a beneficial effect of reducing dietary GI and GL on weight loss, ${ }^{8,} 12$ others did not. ${ }^{9-11}$ Few long term cohort studies among free-living populations have been conducted to explore associations between GI or GL and weight change. ${ }^{15,} 16$ In these two cohort studies, a positive association between GI, but not GL, and weight change has been observed, at least in subgroups. ${ }^{16}$ Compared with our study, these studies were much smaller in sample size, were conducted among a more homogeneous population, and had measured weight data. In our study, however, weight was partly self-reported in four out of six 
of the study centers. However, when we look at the association in UK-Nor and NLDoe, where weight change was measured, GI was inversely, instead of positively, associated with weight change. This rules out the possibility that the different findings in our study compared to the previous ones were due to the self-reported weight change.

The association of GI and GL with waist circumference change has been less investigated. In a Danish population, Hare-Bruun et al have observed a marginally positive association between GI and waist circumference change in women (a 10-unit GI difference was associated with $2 \mathrm{~cm}$ waist circumference enlargement in 6 years), but not in men. ${ }^{16}$ However, this association was not independent of weight change because GI was also positively and significantly associated with weight change. In the current study, a 10-unit GI difference was associated with a waist circumference change of $0.19 \mathrm{~cm} /$ year or $0.26 \mathrm{~cm} /$ year depending on the adjustment strategies applied. Although weaker as compared to previously observed, 16 this association was independent of weight change because GI was not in an overall association with weight change. Increase in waist circumference independent of weight change indicates an accumulation of visceral fat, which has been found strongly associated with insulin resistance, and thus the risk of type 2 diabetes and CVD. ${ }^{38}$ The reason that GI was associated with waist circumference change but not weight change may be due to the characteristic of visceral fat that it is more vulnerable to the influence of high insulin responses stimulated by high GI foods as compared to subcutaneous fat. Therefore visceral fat may be a marker of a disturbed metabolic state, and eventually cause insulin resistance, metabolic syndrome and CVD. ${ }^{39}$ Another possibility might be simply due to the underreporting in dietary data. There is evidence that underreporting is less waist-related than weight-related, ${ }^{40}$ which may be due to the higher awareness of the importance of a healthy BMI than a healthy waist circumference.

The exact reason of heterogeneity observed in the current study was unknown. However, the sources of study population in different centers may partly explain the phenomenon. For example, in IT-Flo, participants came from a sample of the general population and women participating in a breast cancer screening program. Participants in UK-Nor were recruited through general practitioners in the Norfolk region. ${ }^{41}$ In NL-Doe, only respondents from a pre-existing cardiovascular disease risk factor monitoring project were invited.42 Although in general there is no reason to assume a priori that these cohorts are different, subtle differences in underreporting of dietary intake and health consciousness among cohorts may exist.

GL was introduced to capture the joint effects of carbohydrates quantity and quality on human health. ${ }^{2}$ It is thought to be superior to either GI or total carbohydrate intake alone. However, for mixed meals, low GL diets can be low in carbohydrates or low in GI or both. Both low fat high carbohydrate diets and low carbohydrate high fat diets have been found to be effective strategies for weight loss in intervention studies.43-46 In our study, when carbohydrate intake was analyzed in 
the same regression models as used for GL, no association with weight and waist circumference change was observed. Also noteworthy, the correlation coefficient between GL and carbohydrates was 0.98 , while it was only 0.36 between GL and GI (data not shown). Therefore, although GL reflects both GI and amount of carbohydrates, the measure in our study was more closely related to the latter. We might therefore have limited ability to evaluate potential effects of GL which extend beyond the effect from total carbohydrates itself.

To conclude, in this large prospective multi-centre cohort study, although the association between GI and weight change was not statistically significant, a positive association between dietary GI and subsequent changes of waist circumference was observed. This finding may implicate that a higher dietary GI could accelerate waist circumference gain, in other words, consuming a low GI diet may protect against the long-term development of abdominal obesity. However, given that only a small effect was observed, further studies are needed to confirm this finding.

\section{References}

1. Jenkins DJ, Wolever TM, Taylor RH, et al. Glycemic index of foods: a physiological basis for carbohydrate exchange. Am J Clin Nutr. 1981;34(3):362-366.

2. Salmeron J, Manson JE, Stampfer MJ, et al. Dietary fiber, glycemic load, and risk of non-insulindependent diabetes mellitus in women. Jama. 1997;277(6):472-477.

3. Ludwig DS. Dietary glycemic index and the regulation of body weight. Lipids. 2003;38(2):117-121.

4. Ball SD, Keller KR, Moyer-Mileur LJ, et al. Prolongation of satiety after low versus moderately high glycemic index meals in obese adolescents. Pediatrics. 2003;111(3):488-494.

5. Stevenson EJ, Williams C, Mash LE, et al. Influence of high-carbohydrate mixed meals with different glycemic indexes on substrate utilization during subsequent exercise in women. Am J Clin Nutr. 2006;84(2):354-360.

6. Pereira MA, Swain J, Goldfine AB, et al. Effects of a low-glycemic load diet on resting energy expenditure and heart disease risk factors during weight loss. Jama. 2004;292(20):2482-2490.

7. Du H, van der A DL, Feskens EJ. Dietary glycaemic index: a review of the physiological mechanisms and observed health impacts. Acta Cardiol. 2006;61(4):383-397.

8. Thomas DE, Elliott E, Baur L. Low glycaemic index or low glycaemic load diets for overweight and obesity. Cochrane Database Syst Rev. 2007(3):CD005105.

9. Aston LM, Stokes CS, Jebb SA. No effect of a diet with a reduced glycaemic index on satiety, energy intake and body weight in overweight and obese women. Int J Obes (Lond). 2008;32(1):160-165.

10. Das SK, Gilhooly CH, Golden JK, et al. Long-term effects of 2 energy-restricted diets differing in glycemic load on dietary adherence, body composition, and metabolism in CALERIE: a 1-y randomized controlled trial. Am J Clin Nutr. 2007;85(4):1023-1030.

11. Sichieri R, Moura AS, Genelhu V, et al. An 18-mo randomized trial of a low-glycemic-index diet and weight change in Brazilian women. Am J Clin Nutr. 2007;86(3):707-713.

12. de Rougemont A, Normand S, Nazare JA, et al. Beneficial effects of a 5-week low-glycaemic index regimen on weight control and cardiovascular risk factors in overweight non-diabetic subjects. $\mathrm{Br} J$ Nutr. 2007;98(6):1288-1298.

13. Astrup A, Meinert Larsen T, Harper A. Atkins and other low-carbohydrate diets: hoax or an effective tool for weight loss? Lancet. 2004;364(9437):897-899.

14. Seidell JC, Nooyens AJ, Visscher TL. Cost-effective measures to prevent obesity: epidemiological basis and appropriate target groups. Proc Nutr Soc. 2005;64(1):1-5.

15. Ma $Y$, Olendzki B, Chiriboga D, et al. Association between dietary carbohydrates and body weight. Am J Epidemiol. 2005;161(4):359-367. 
16. Hare-Bruun H, Flint A, Heitmann BL. Glycemic index and glycemic load in relation to changes in body weight, body fat distribution, and body composition in adult Danes. Am J Clin Nutr. 2006;84(4):871-879; quiz 952-873.

17. Riboli E, Hunt KJ, Slimani N, et al. European Prospective Investigation into Cancer and Nutrition (EPIC): study populations and data collection. Public Health Nutr. 2002;5(6B):1113-1124.

18. Kaaks R, Slimani N, Riboli E. Pilot phase studies on the accuracy of dietary intake measurements in the EPIC project: overall evaluation of results. European Prospective Investigation into Cancer and Nutrition. Int J Epidemiol. 1997;26 Suppl 1:S26-36.

19. Pisani $P$, Faggiano F, Krogh V, et al. Relative validity and reproducibility of a food frequency dietary questionnaire for use in the Italian EPIC centres. Int J Epidemiol. 1997;26 Suppl 1:S152-160.

20. Bingham SA, Gill C, Welch A, et al. Validation of dietary assessment methods in the UK arm of EPIC using weighed records, and 24-hour urinary nitrogen and potassium and serum vitamin $C$ and carotenoids as biomarkers. Int J Epidemiol. 1997;26 Suppl 1:S137-151.

21. Bohlscheid-Thomas S, Hoting I, Boeing $H$, et al. Reproducibility and relative validity of energy and macronutrient intake of a food frequency questionnaire developed for the German part of the EPIC project. European Prospective Investigation into Cancer and Nutrition. Int J Epidemiol. 1997;26 Suppl 1:S71-81.

22. Bohlscheid-Thomas S, Hoting I, Boeing H, et al. Reproducibility and relative validity of food group intake in a food frequency questionnaire developed for the German part of the EPIC project. European Prospective Investigation into Cancer and Nutrition. Int J Epidemiol. 1997;26 Suppl 1:S59-70.

23. Ocke MC, Bueno-de-Mesquita HB, Pols MA, et al. The Dutch EPIC food frequency questionnaire. II. Relative validity and reproducibility for nutrients. Int J Epidemiol. 1997;26 Suppl 1:S49-58.

24. Ocke MC, Bueno-de-Mesquita HB, Goddijn HE, et al. The Dutch EPIC food frequency questionnaire. I. Description of the questionnaire, and relative validity and reproducibility for food groups. Int J Epidemiol. 1997;26 Suppl 1:S37-48.

25. van Bakel MM, Slimani N, Feskens EJ, et al. Methodological challenges in the application of the glycemic index in epidemiological studies using data from the European Prospective Investigation into Cancer and Nutrition. J Nutr. 2009;139(3):568-575.

26. Du H, van der A DL, van Bakel MM, et al. Glycemic index and glycemic load in relation to food and nutrient intake and metabolic risk factors in a Dutch population. Am J Clin Nutr. 2008;87(3):655-661.

27. Du H, van der A DL, van Bakel MM, et al. Reproducibility and relative validity of dietary glycaemic index and glycaemic load assessed by the food-frequency questionnaire used in the Dutch cohorts of the European Prospective Investigation into Cancer and Nutrition. Br J Nutr. 2009;102(4):601-604.

28. Slimani N, Kaaks R, Ferrari P, et al. European Prospective Investigation into Cancer and Nutrition (EPIC) calibration study: rationale, design and population characteristics. Public Health Nutr. 2002;5(6B):1125-1145.

29. Ferrari P, Day NE, Boshuizen HC, et al. The evaluation of the diet/disease relation in the EPIC study: considerations for the calibration and the disease models. Int J Epidemiol. 2008;37(2):368-378.

30. Slimani N, Deharveng G, Charrondiere RU, et al. Structure of the standardized computerized 24-h diet recall interview used as reference method in the 22 centers participating in the EPIC project. European Prospective Investigation into Cancer and Nutrition. Computer methods and programs in biomedicine. 1999;58(3):251-266.

31. Slimani N, Deharveng G, Unwin I, et al. The EPIC nutrient database project (ENDB): a first attempt to standardize nutrient databases across the 10 European countries participating in the EPIC study. Eur J Clin Nutr. 2007;61(9):1037-1056.

32. Ledikwe JH, Blanck HM, Khan LK, et al. Dietary energy density determined by eight calculation methods in a nationally representative United States population. J Nutr. 2005;135(2):273-278.

33. Bes-Rastrollo M, van Dam RM, Martinez-Gonzalez MA, et al. Prospective study of dietary energy density and weight gain in women. Am J Clin Nutr. 2008;88(3):769-777.

34. Kien CL, Ugrasbul F. Prediction of daily energy expenditure during a feeding trial using measurements of resting energy expenditure, fat-free mass, or Harris-Benedict equations. Am J Clin Nutr. 2004;80(4):876-880. 
35. Haftenberger M, Lahmann PH, Panico S, et al. Overweight, obesity and fat distribution in 50- to 64year-old participants in the European Prospective Investigation into Cancer and Nutrition (EPIC). Public Health Nutr. 2002;5(6B):1147-1162.

36. Willett WC. Anthropometric measures and body composition. Nutritional Epidemiology. 2nd edition. New York: Oxford University Press; 1998.

37. Mason C, Katzmarzyk PT. Variability in Waist Circumference Measurements According to Anatomic Measurement Site. Obesity (Silver Spring). 2009;17(9):1789-1795.

38. Ross R, Freeman J, Hudson R, et al. Abdominal obesity, muscle composition, and insulin resistance in premenopausal women. J Clin Endocrinol Metab. 2002;87(11):5044-5051.

39. Despres JP, Lemieux I, Bergeron J, et al. Abdominal obesity and the metabolic syndrome: contribution to global cardiometabolic risk. Arterioscler Thromb Vasc Biol. 2008;28(6):1039-1049.

40. Mattisson I, Wirfalt E, Aronsson CA, et al. Misreporting of energy: prevalence, characteristics of misreporters and influence on observed risk estimates in the Malmo Diet and Cancer cohort. $\mathrm{Br} J$ Nutr. 2005;94(5):832-842.

41. Day N, Oakes S, Luben R, et al. EPIC-Norfolk: study design and characteristics of the cohort. European Prospective Investigation of Cancer. Br J Cancer. 1999;80 Suppl 1:95-103.

42. Verschuren WM, Blokstra A, Picavet HS, et al. Cohort profile: the Doetinchem Cohort Study. Int J Epidemiol. 2008;37(6):1236-1241.

43. Nordmann AJ, Nordmann A, Briel M, et al. Effects of low-carbohydrate vs low-fat diets on weight loss and cardiovascular risk factors: a meta-analysis of randomized controlled trials. Arch Intern Med. 2006;166(3):285-293.

44. Shai I, Schwarzfuchs D, Henkin Y, et al. Weight loss with a low-carbohydrate, Mediterranean, or lowfat diet. N Engl J Med. 2008;359(3):229-241.

45. Saris WH, Astrup A, Prentice AM, et al. Randomized controlled trial of changes in dietary carbohydrate/fat ratio and simple vs complex carbohydrates on body weight and blood lipids: the CARMEN study. The Carbohydrate Ratio Management in European National diets. Int J Obes Relat Metab Disord. 2000;24(10):1310-1318.

46. Astrup A, Grunwald GK, Melanson EL, et al. The role of low-fat diets in body weight control: a metaanalysis of ad libitum dietary intervention studies. Int J Obes Relat Metab Disord. 2000;24(12):1545-1552. 


\begin{tabular}{|c|c|c|c|c|c|c|}
\hline \multicolumn{7}{|c|}{ S-Table 5-1. Characteristics of study participants and associations of across study centre. } \\
\hline Characteristics* & IT-Flo & UK-Nor & $\begin{array}{c}\text { NL- } \\
\text { AmMa }\end{array}$ & NL-Doe & GER-Pot & $\begin{array}{c}\text { DK- } \\
\text { CopAa }\end{array}$ \\
\hline $\mathrm{N}$ & 9,297 & 12,808 & 6,911 & 4,200 & 16,307 & 39,909 \\
\hline Glycemic index (GI) & $56 \pm 1.2$ & $57 \pm 1.4$ & $58 \pm 2.5$ & $58 \pm 2.2$ & $54 \pm 1.6$ & $58 \pm 2.3$ \\
\hline Baseline age, yrs & $51 \pm 7.6$ & $58 \pm 8.9$ & $42 \pm 10.6$ & $46 \pm 9.7$ & $50 \pm 8.8$ & $56 \pm 4.3$ \\
\hline Gender, \% men & 22 & 44 & 43 & 48 & 38 & 46 \\
\hline Follow-up length, yrs & $9.4 \pm 1.1$ & $3.7 \pm 0.7$ & $10.0 \pm 1.4$ & $5.0 \pm 0.2$ & $8.6 \pm 0.8$ & $5.4 \pm 0.3$ \\
\hline Baseline weight, $\mathrm{kg}$ & $67 \pm 11.9$ & $73 \pm 12.6$ & $73 \pm 13.0$ & $77 \pm 12.9$ & $73 \pm 13.7$ & $75 \pm 13.6$ \\
\hline Baseline BMI, $\mathrm{kg} / \mathrm{m}^{2}$ & $25.2 \pm 3.8$ & $26.0 \pm 3.7$ & $24.9 \pm 3.7$ & $25.7 \pm 3.5$ & $25.9 \pm 4.0$ & $25.8 \pm 3.8$ \\
\hline Overweight, \% & 37 & 45 & 35 & 44 & 41 & 42 \\
\hline Obesity, \% & 10 & 13 & 9 & 10 & 14 & 13 \\
\hline Baseline waist, $\mathrm{cm}$ & $80 \pm 10.9$ & $87 \pm 12.0$ & $84 \pm 11.8$ & $90 \pm 11.0$ & $85 \pm 12.5$ & $88 \pm 12.3$ \\
\hline Total energy, kcal/d & $2,009 \pm 426$ & $1,971 \pm 354$ & $2,366 \pm 566$ & $2,385 \pm 556$ & $2,156 \pm 456$ & $2,288 \pm 419$ \\
\hline Energy density, $k c a l / g$ & $1.51 \pm 0.17$ & $1.67 \pm 0.20$ & $1.86 \pm 0.29$ & $1.68 \pm 0.23$ & $1.62 \pm 0.24$ & $1.83 \pm 0.26$ \\
\hline Fat, En \% & $32.3 \pm 2.4$ & $32.2 \pm 2.8$ & $36.1 \pm 3.8$ & $35.1 \pm 2.9$ & $38.1 \pm 2.7$ & $36.4 \pm 3.0$ \\
\hline Protein, En \% & $16.7 \pm 1.2$ & $16.3 \pm 1.2$ & $15.3 \pm 1.4$ & $16.0 \pm 1.4$ & $13.9 \pm 0.8$ & $14.7 \pm 0.9$ \\
\hline Carbohydrates, En \% & $47.5 \pm 2.7$ & $46.2 \pm 2.3$ & $43.1 \pm 3.8$ & $44.3 \pm 4.6$ & $43.3 \pm 4.1$ & $40.8 \pm 4.0$ \\
\hline Polysaccharides, En \% & $30.0 \pm 3.3$ & $22.8 \pm 1.1$ & $21.9 \pm 2.6$ & $21.5 \pm 2.6$ & $19.2 \pm 2.2$ & $20.5 \pm 2.6$ \\
\hline Mono-disaccharides, En \% & $17.5 \pm 2.1$ & $23.4 \pm 3.0$ & $21.1 \pm 3.4$ & $22.8 \pm 4.0$ & $22.4 \pm 4.4$ & $17.9 \pm 3.1$ \\
\hline Glycemic load & $135 \pm 29$ & $130 \pm 25$ & $148 \pm 37$ & $153 \pm 40$ & $124 \pm 25$ & $135 \pm 27$ \\
\hline Fiber, $g / d$ & $22.1 \pm 4.5$ & $18.6 \pm 2.9$ & $22.7 \pm 5.8$ & $23.9 \pm 6.3$ & $22.1 \pm 3.8$ & $24.6 \pm 5.3$ \\
\hline \multicolumn{7}{|l|}{ Smoking status ${ }^{+, \neq}, \%$} \\
\hline Stable smoking & 17 & 7 & 21 & 24 & 12 & 25 \\
\hline Start smoking & 1 & 1 & 2 & 2 & 2 & 2 \\
\hline Quit smoking & 9 & 2 & 13 & 5 & 5 & 7 \\
\hline Not smoking & 72 & 90 & 63 & 68 & 81 & 65 \\
\hline \multicolumn{7}{|l|}{ Education ${ }^{+}, \S, \%$} \\
\hline Primary school or lower & 43 & 35 & 9 & 8 & 18 & 30 \\
\hline Technical school & 12 & 42 & 32 & 46 & 37 & 39 \\
\hline Secondary school & 26 & 9 & 27 & 25 & 7 & 11 \\
\hline University or higher & 18 & 14 & 32 & 21 & 39 & 20 \\
\hline \multicolumn{7}{|l|}{ Physical activity } \\
\hline Inactive & 25 & 35 & 9 & 3 & 21 & 9 \\
\hline Moderately inactive & 41 & 42 & 25 & 21 & 39 & 31 \\
\hline Moderately active & 19 & 9 & 27 & 29 & 24 & 25 \\
\hline Active & 15 & 14 & 39 & 46 & 16 & 35 \\
\hline Post-menopausal women, $\%$ & 52 & 68 & 17 & 24 & 42 & 73 \\
\hline Hormone-use womenI, \% & 9 & 22 & 5 & 4 & 24 & 30 \\
\hline
\end{tabular}





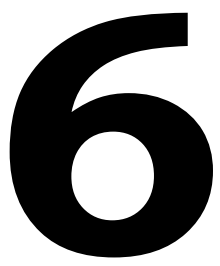

\title{
Dietary energy density in relation to subsequent changes of weight and waist circumference in European men and women
}

\author{
H. Du, D. L. van der A, V. Ginder, S. A. Jebb, N. G. Forouhi, \\ N. J. Wareham, J. Halkjaer, A. Tjønneland, K. Overvad, \\ M. Uhre Jakobsen, B. Buijsse, A. Steffen, D. Palli, G. Masala, \\ W. H.M. Saris, T. I.A. Sørensen, E. J.M. Feskens.
}

Plos ONE. 2009;4(4):e5339

\begin{abstract}
Background: Experimental studies show that a reduction in dietary energy density (ED) is associated with reduced energy intake and body weight. However, few observational studies have investigated the role of ED on long-term weight and waist circumference change.

Methods and Principal Findings: This population-based prospective cohort study included 89,432 participants from five European countries with mean age 53 years (range: 20-78 years) at baseline and were followed for an average of 6.5 years (range: 1.9-12.5 years). Participants were free of cancer, cardiovascular diseases and diabetes at baseline. ED was calculated as the energy intake (kcal) from foods divided by the weight (g) of foods. Multiple linear regression analyses were performed to investigate the associations of ED with annual weight and waist circumference change.

Mean ED was $1.7 \mathrm{kcal} / \mathrm{g}$ and differed across study centers. After adjusting for baseline anthropometrics, demographic and lifestyle factors, follow-up duration and energy from beverages, ED was not associated with weight change, but significantly associated with waist circumference change overall. For $1 \mathrm{kcal} / \mathrm{g}$ ED, the annual weight change was -42 g/year [95\% confidence interval (CI): -112, 28] and annual waist circumference change was $0.09 \mathrm{~cm} /$ year [95\% CI: 0.01, 0.18]. In participants with baseline $\mathrm{BMI}<25 \mathrm{~kg} / \mathrm{m}^{2}, 1 \mathrm{kcal} / \mathrm{g}$ ED was associated with a waist circumference change of $0.17 \mathrm{~cm} /$ year [ $95 \%$ CI: $0.09,0.25]$.

Conclusion: Our results suggest that lower ED diets do not prevent weight gain but have a weak yet potentially beneficial effect on the prevention of abdominal obesity as measured by waist circumference.
\end{abstract}




\section{Introduction}

The global obesity epidemic triggers research investigating the dietary determinants of a positive energy balance. The energy density (ED) of foods or diets, defined as the amount of available energy per unit weight of foods or meals $(\mathrm{kJ} / \mathrm{g}$ or $\mathrm{kcal} / \mathrm{g}),{ }^{1}$ has gained much attention in this respect. ${ }^{2}$ For example, the joint WHO / FAO expert consultation on diet, nutrition and the prevention of chronic diseases classifies the evidence of a positive relationship between high intake of energy-dense foods and weight gain and obesity as convincing. ${ }^{3}$ In addition, the Dietary Guidelines for Americans 2005 recommend eating foods that are low in calories for a given measure of food to reduce calorie intake. ${ }^{4}$

Experimental data suggest that people tend to eat a similar volume of food to feel satiated, and, accordingly, consuming energy-dense foods could cause passive overeating in terms of energy. ${ }^{2}$ Furthermore, energy-dense foods high in fat and sugar tend to be highly palatable and stimulate over-eating 5 . Some cross-sectional studies show a positive association between ED and obesity but there are concerns about reverse causality.1, 6 Intervention studies among overweight and obese subjects consistently demonstrate that ED reduction is associated with weight loss.-9 However, these interventions were of relatively short period. Findings from observational studies, on the other hand, are less consistent. For instance, in two recently published studies among US women, higher ED has been found to predict higher weight gain. ${ }^{10,11}$ However, no such significant relationship was observed in an earlier study among Danish adults. ${ }^{12}$ In a study among British children, higher ED at seven years of age, but not at 5 years of age, has been found to be a risk factor for excessive adiposity at the age of nine years. ${ }^{13}$

The present study was conducted to examine the prospective relationship between dietary ED and long-term (1.9-12.5 years) changes in body weight and waist circumference within a large European study, which is a part of the DiOGenes project (acronym for "Diet, Obesity and Genes"). ${ }^{14}$

\section{Methods \\ Participants}

The current study included participants from eight cities or counties in five different countries involved in the European Prospective Investigation into Cancer and Nutrition (EPIC) study, namely Florence (Italy), Norfolk (the UK), Amsterdam, Maastricht and Doetinchem (The Netherlands), Potsdam (Germany), Copenhagen and Aarhus (Denmark). EPIC study has been approved by local review board of all participating institutions. Written informed consent has been obtained from all participants before joining EPIC study. Detailed information on the study population and data collection of the EPIC study has been described elsewhere. ${ }^{15}$ Of the 146,543 participants who took part in the baseline examination during 1992-1998, 102,346 (69.8\%) participated in the follow-up examination during 1998-2005. For the present 
study, the following exclusion criteria were applied: pregnancy ( $\mathrm{n}=133$ ), missing information on diet, anthropometrics or follow-up time ( $n=2,135)$, the ratio of energy intake (EI) to estimated basal metabolic rate (BMR) (EI: BMR) being top or bottom $1 \%$ of the entire EPIC population $(n=1,803)$, unrealistic anthropometric measurements $(n=331)$ and those with history of cancer, diabetes or cardiovascular diseases (CVD) at baseline ( $\mathrm{n}=8,512)$. In total, 89,432 participants, 37,125 (42\%) men and 52,307 (58\%) women, were included in the analyses.

\section{Dietary assessment}

Country-specific food frequency questionnaires (FFQs) were self-administered at baseline. Energy and nutrient intakes were calculated using country-specific food composition tables. ${ }^{15}$ ED was calculated as energy (kcal) from foods (solid foods and semi-solid or liquid foods such as soups) divided by the weights ( $g$ ) of these foods. Drinks (including water, tea, coffee, juice, soft drinks, alcoholic drinks and milk) were not included in the calculation. ${ }^{16}$ To improve comparability of dietary data collected using different FFQs, and to adjust for measurement errors, linear calibration was performed with single 24-hour dietary recall from a stratified random sample of the total EPIC study population as reference method. ${ }^{17,18}$ Among the 89,432 participants included in the current study, 6,790 participants had also 24hour dietary recall data available. This 24-hour dietary recall was collected using a software program (EPIC-SOFT) specifically designed to standardize the dietary measurements across European populations. ${ }^{19}$ Nutrient intake in this 24-hour recall data were standardized based on the standardized nutrient database developed within the EPIC study (ENDB). ${ }^{20}$ Gender- and center-specific calibration models were built with 24-hour recall data as the dependent variable and FFQ data as the independent variable. Age, weight, height, and season in which the FFQ measurement was conducted were adjusted for. Under-reporting of EI was assessed by EI: BMR < 1.1,11 where BMR was estimated using Harris-Benedict equations. ${ }^{21}$

\section{Anthropometric measurements}

Weight and waist circumference were collected at baseline and at the end of follow-up. At baseline, all participants were measured by trained technicians for weight, height and waist circumference using standard study protocols as previously described. ${ }^{22}$ At follow-up, participants in Doetinchem (NL) and Norfolk (UK) were measured by trained technicians, while those in the other centers provided selfreported weight and waist circumference. Annual changes in weight (g/year) and waist circumference (cm/year) were calculated as follow-up values minus baseline values and divided by the total years of follow-up. Due to differences in methods used to collect anthropometric information at follow-up and the length of follow-up time, participants from Doetinchem (NL) were treated separately from those from Amsterdam and Maastricht (NL), while participants from Copenhagen and Aarhus (DK) were combined because no such differences between these two groups existed. 
Thus six study centers were formed, namely Florence (IT-Flo) $(\mathrm{n}=9,297,10 \%)$, Norfolk (UK-Nor) ( $\mathrm{n}=12,808,14 \%)$, Amsterdam-Maastricht (NL-AmMa) $(\mathrm{n}=6,911$, $8 \%)$, Doetinchem (NL-Doe) $(n=4,200,5 \%)$, Potsdam (GER-Pot) $(n=16,307,18 \%)$ and Copenhagen-Aarhus (DK-CopAa) $(n=39,909,45 \%)$.

\section{Other covariates}

Information on lifestyle was collected via self-administrated questionnaires. Questions covered age, gender, education level, physical activity, smoking, menopausal status, and use of hormone replacement therapy (HRT). Information on health status, including CVD, cancer and diabetes, was collected using either questionnaires or disease registries. Assessment of physical activity level was indexed into four categories based on their occupational and recreational activities. Education level was inquired as the highest level of school achieved. Based on the information of smoking status at baseline as well as at follow-up, participants were classified into one of the following four categories: stable smoking, start smoking, quit smoking, non- smoking or unknown.

\section{Statistical methods}

Characteristics of participants were given along quintiles of ED. Stepwise regression analyses were conducted to investigate the contribution of food groups and nutrients to the inter-individual variation in ED. Fifteen food group variables were entered into the regression model, including potatoes, vegetables, legumes, fruits, dairy products, cereals, meat, fish, eggs, fats, sugar and confectionery, cakes, condiments and sauces, soups and miscellaneous. ${ }^{23}$ As for nutrients, six macronutrient variables, including saturated fatty acids, monounsaturated fatty acids, polyunsaturated fatty acids, polysaccharides, mono-\&disaccharides and protein were entered in the regression model.

The association of ED with annual weight and waist circumference change was investigated using multiple linear regression analyses. Center-specific analyses were first performed and random-effect meta-analyses were used to evaluate heterogeneity $\left(I^{2}\right)$ and obtain pooled estimates of associations. Analyses were adjusted for a pre-decided set of potential confounders including baseline age (years), gender, height $(\mathrm{cm})$, baseline weight $(\mathrm{kg})$ and waist circumference $(\mathrm{cm}$, only for waist circumference change analyses), smoking, physical activity (inactive, moderately inactive, moderately active, active or missing), education (primary school and less, technical-professional school, secondary school, university degree or missing), follow-up time (years), alcohol intake (non-drinker, 0.1-4.9g/day, 4.9-15 g/day, 15-30 g/day, 30-60 g/day, >60 g/day), energy intake from beverages, and among women only, menopausal status (postmenopausal yes or no) and HRT use (yes, no, or missing).

Interactions of ED with age, gender, baseline BMI, smoking, EI:BMR, follow-up duration, and baseline waist circumference (for waist circumference change analyses 
only) were investigated by introducing product terms into the models. A two-sided $P<0.05$ was considered statistically significant in the analyses of main effects, whereas $P<0.01$ in at least three of the six study centers was considered relevant when testing of interaction.

\begin{tabular}{|c|c|c|c|c|c|c|}
\hline Characteristics* $^{*}$ & Overall & Q1 & Q2 & Q3 & Q4 & Q5 \\
\hline Energy density, kcal/g & $1.7 \pm 0.27$ & 1.4 & 1.6 & 1.7 & 1.9 & 2.1 \\
\hline Baseline age, yrs & $53 \pm 8.6$ & 54 & 54 & 54 & 53 & 52 \\
\hline Gender, $\%$ of men & 42 & 11 & 26 & 41 & 58 & 73 \\
\hline Follow-up duration, yrs & $6.5 \pm 2.2$ & 7.3 & 6.6 & 6.2 & 6.1 & 6.2 \\
\hline Baseline weight, $\mathrm{kg}$ & $73.4 \pm 13.5$ & 69.4 & 71.0 & 73.2 & 75.7 & 77.8 \\
\hline Baseline BMI, $\mathrm{kg} / \mathrm{m}^{2}$ & $25.7 \pm 3.8$ & 25.9 & 25.7 & 25.6 & 25.7 & 25.7 \\
\hline Baseline waist circumference, $\mathrm{cm}$ & $86 \pm 12$ & 82 & 84 & 86 & 88 & 90 \\
\hline Total energy, kcal/day & $2,200 \pm 460$ & 1,860 & 2,032 & 2,197 & 2,363 & 2,549 \\
\hline Energy from beverages, kcal/day & $350 \pm 169$ & 260 & 302 & 348 & 394 & 447 \\
\hline Total gram of foods, g/day & $1,308 \pm 260$ & 1,315 & 1,312 & 1,318 & 1,316 & 1,281 \\
\hline Fiber ${ }^{\dagger}$, g/day & $22.8 \pm 4.0$ & 23.6 & 22.9 & 22.9 & 22.8 & 22.1 \\
\hline Glycemic index ${ }^{+}$ & $57 \pm 2.0$ & 55 & 56 & 57 & 58 & 59 \\
\hline Glycemic load $^{+}$ & $134 \pm 22$ & 124 & 130 & 134 & 139 & 143 \\
\hline \multicolumn{7}{|l|}{ Smoking status $\ddagger \S, \%$} \\
\hline Stable smoking & 19 & 12 & 14 & 17 & 22 & 31 \\
\hline Start smoking & 2 & 2 & 1 & 2 & 2 & 2 \\
\hline Quit smoking & 7 & 6 & 6 & 6 & 7 & 9 \\
\hline Non-smoking & 72 & 81 & 79 & 75 & 69 & 58 \\
\hline \multicolumn{7}{|l|}{ Education $\neq \|, \%$} \\
\hline Primary school or lower & 27 & 30 & 28 & 25 & 25 & 28 \\
\hline Technical/professional school & 36 & 33 & 36 & 37 & 38 & 37 \\
\hline Secondary school & 13 & 15 & 14 & 13 & 12 & 11 \\
\hline University degree or higher & 23 & 22 & 22 & 24 & 26 & 24 \\
\hline \multicolumn{7}{|l|}{ Physical activity $\ddagger, \mathbb{I I}, \%$} \\
\hline Inactive & 16 & 19 & 18 & 16 & 14 & 13 \\
\hline Moderately inactive & 33 & 36 & 35 & 33 & 32 & 29 \\
\hline Moderately active & 24 & 23 & 23 & 25 & 25 & 24 \\
\hline Active & 27 & 22 & 24 & 26 & 29 & 34 \\
\hline Post menopausal women, \% & 57 & 58 & 57 & 57 & 56 & 57 \\
\hline Hormone-use women $\$$, \% & 22 & 21 & 22 & 22 & 22 & 22 \\
\hline \multicolumn{7}{|c|}{$\begin{array}{l}{ }^{*} \text { Expressed as means (or mean } \pm \text { SD), otherwise indicated. Differences between quintile groups were tested using } \\
\text { chi-square test (categorical variables) or ANOVA test (continuous variable). } P<0.0001 \text { for all. }{ }^{+} \text {Energy-adjusted } \\
\text { residuals of dietary variables. } \\
\ddagger \text { Percentages are based on those participants with available data on that variable and may not sum to } 100 \% \text { due } \\
\text { to rounding. }{ }^{\$} 1,440 \text { participants with missing values. } \| 1,579 \text { participants with missing values. }{ }^{\circledR} 3,319 \text { participants } \\
\text { with missing values. }{ }^{\$} 1,273 \text { participants with missing values. }\end{array}$} \\
\hline
\end{tabular}


We performed several sensitivity analyses, including use un-calibrated dietary variables; use corrected anthropometric variables based on the equations developed in EPIC study; ${ }^{24}$ exclude participants who developed type 2 diabetes, cancer, or CVD during follow-up; and additionally adjust for individual food or nutrient variables which potentially mediate the effects of ED on weight and waist circumference change, including total energy, fruits, vegetables, total fat, saturated fatty acids, dietary fiber, glycemic index and glycemic load. Except for the random-effect metaanalyses, which were conducted using STATA 8.2 (StataCorp, Texas, USA), all other statistical analyses were performed using SAS 9.1 (SAS, Institute, Cary, NC).

\section{Results}

The mean baseline age was 53 years (range: 20-78 years) and mean follow-up duration was 6.5 years (range: 1.9-12.5 years). At baseline, $12 \%$ of participants were obese $\left(B M I \geq 30 \mathrm{~kg} / \mathrm{m}^{2}\right)$; a further $41 \%$ were overweight $\left(30 \mathrm{~kg} / \mathrm{m}^{2}>\mathrm{BMI} \geq 25 \mathrm{~kg} / \mathrm{m}^{2}\right)$; and $21 \%$ had abdominal obesity (waist circumference $\geq 102 \mathrm{~cm}$ for men and $\geq 88 \mathrm{~cm}$ for women) (data not shown). On average, participants in NL-AmMa were the youngest at baseline (42 years) and were followed for a longest period (10 years), while those from UK-Nor were the oldest at baseline (58 years) and with the shortest follow-up duration (3.7 years). Annual weight change was higher in NL-Doe (mean = $440 \mathrm{~g} /$ year) and UK-Nor (374 g/year) compared to the weight change in the other centers with self-reported weight at follow-up (164 g/year, 164 g/year, $183 \mathrm{~g} /$ year and -51 g/year respectively for participants from IT-Flo, NL-AmMa, GER-Pot and DKCopAa). However, for waist circumference change, the highest value was observed in DK-CopAa $(0.96 \mathrm{~cm} /$ year), followed by the waist circumference change in the ITFlo $(0.84 \mathrm{~cm} /$ year), GER-Pot $(0.76 \mathrm{~cm} /$ year $)$, NL-AmMa $(0.63 \mathrm{~cm} /$ year $)$, and NL-Doe $(0.58 \mathrm{~cm} /$ year $)$, and the lowest in UK-Nor $(0.22 \mathrm{~cm} /$ year $)$.

The overall mean ED was $1.7 \mathrm{kcal} / \mathrm{g}$ and higher in men $(1.9 \mathrm{kcal} / \mathrm{g})$ than in women $(1.6 \mathrm{kcal} / \mathrm{g})$. Participants in NL-AmMa had the highest ED $(1.9 \mathrm{kcal} / \mathrm{g})$, followed by those from DK-CopAa $(1.8 \mathrm{kcal} / \mathrm{g})$, UK-Nor $(1.7 \mathrm{kcal} / \mathrm{g})$, NL-Doe $(1.7$ $\mathrm{kcal} / \mathrm{g})$, and GER-Pot $(1.6 \mathrm{kcal} / \mathrm{g})$, and the lowest was observed among those from ITFlo (1.5 kcal/g). Although consuming lower amount (total grams) of foods, participants with higher ED had greater intake of total energy and energy from beverages. They smoked more and were more physically active. Those in the higher ED quintile groups also had lower fiber intake and higher dietary glycemic index and glycemic load (Table 6-1).

Among foods, fruits explained the most variation in ED (35\%), followed by sugar and confectionery, fats, and vegetables (13\%, $8 \%$ and $7 \%$ respectively) (Table 6-2). ED was inversely associated with the intake of fruits and vegetables but positively associated with the intake of fats and sugar and confectionery. Among nutrients, saturated fatty acids explained the most variation in ED (24\%).

After adjusting for the aforementioned covariates, there was no significant overall association between ED and annual weight change. The mean weight change 
for each $1 \mathrm{kcal} / \mathrm{g}$ ED was -42 g/year [95\% confidence interval (CI): -112, 28]. A significant degree of heterogeneity across study centers was observed $\left(I^{2}=86 \%, P\right.$ for heterogeneity < 0.001). In IT-Flo, ED was inversely, but not significantly, associated with weight change. In NL-AmMa and DK-CopAa, the associations were toward a positive direction. The inverse associations in UK-Nor and NL-Doe and the positive association in GER-Pot were statistically significant (Figure 6-1).

ED was positively and significantly associated with waist circumference change in IT-Flo, NL-AmMa, GER-Pot and DK-CopAa. In UK-Nor, ED was inversely but not significantly associated with waist circumference change. In NL-Doe, ED was inversely and significantly associated with waist circumference change. Overall, 1 $\mathrm{kcal} / \mathrm{g}$ ED was associated with a waist circumference change of $0.09 \mathrm{~cm} /$ year [95\% CI: $0.01,0.18]\left(I^{2}=84 \%, P\right.$ for heterogeneity < 0.001) (Figure 6-2).

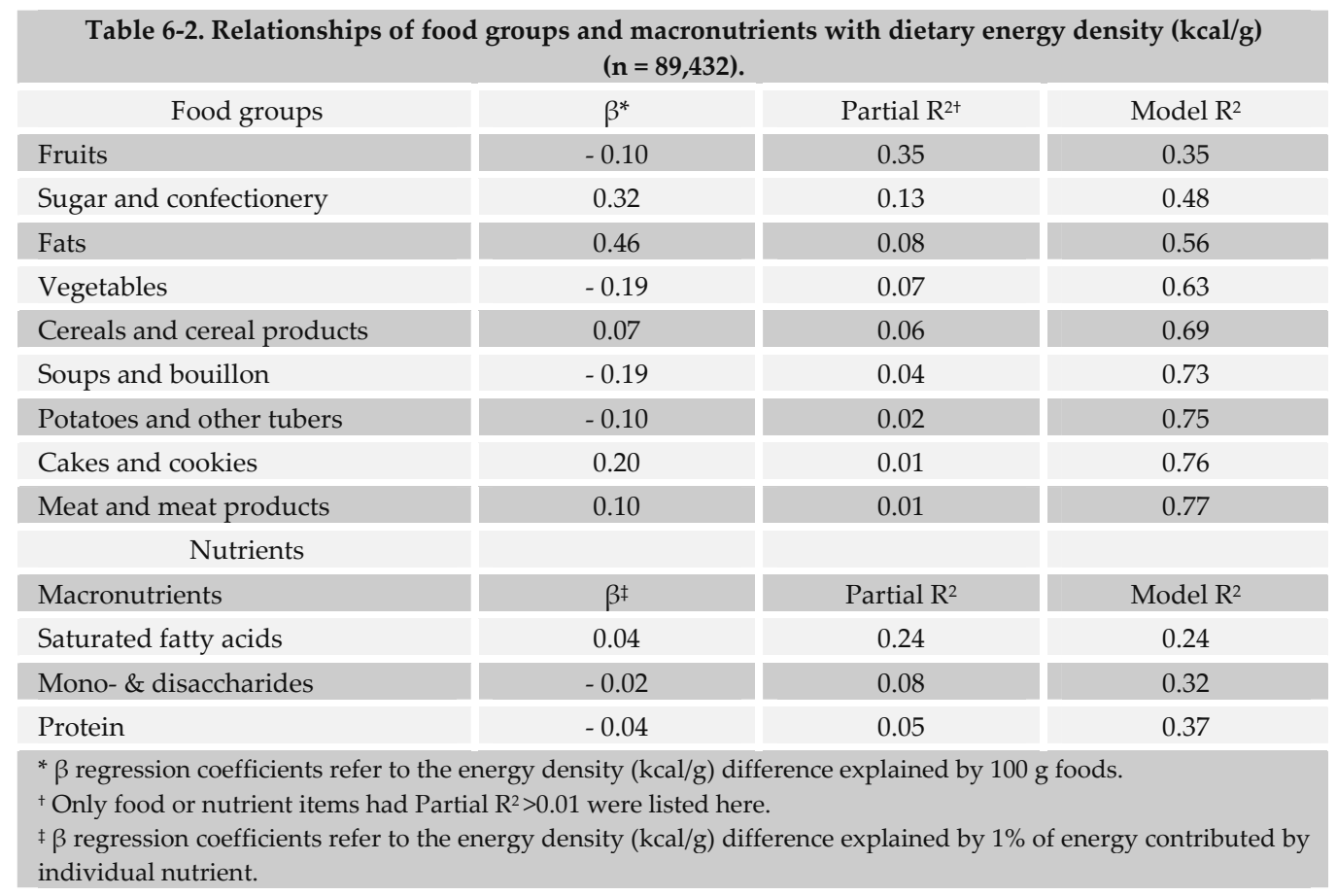

Only baseline BMI fulfilled the pre-decided criteria for being a significant effect modifier. Among participants with baseline BMI $<25 \mathrm{~kg} / \mathrm{m}^{2}$, ED was in the direction of positively associated with weight change: $1 \mathrm{kcal} / \mathrm{g}$ ED was associated with a weight change of $29 \mathrm{~g} /$ year [95\% CI: -19, 77] (Figure 6-3a). However, among those participants who were overweight or obese at baseline (BMI $\geq 25 \mathrm{~kg} / \mathrm{m}^{2}$ ), ED was inversely associated with weight change: $1 \mathrm{kcal} / \mathrm{g}$ ED was associated with a weight change of -103 g/year [95\% CI: -223, 18] (Figure 6-3b). In IT-Flo, ED was significantly and positively associated with weight change among those participants with BMI < $25 \mathrm{~kg} / \mathrm{m}^{2}$ but inversely among those BMI $\geq 25 \mathrm{~kg} / \mathrm{m}^{2}$. In UK-Nor and NL-Doe, the 
inverse association between ED and weight change was much weaker among participants who had a healthy BMI at baseline compared to the association in

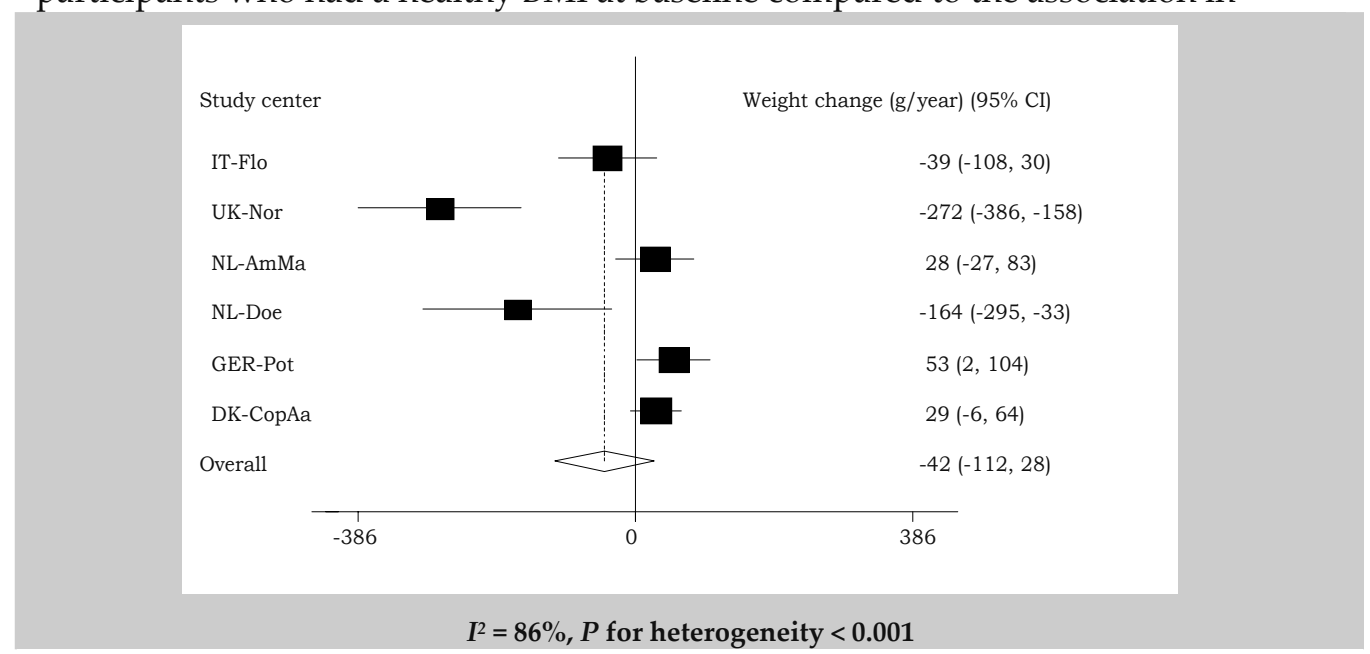

95\% CI: 95\% Confidence interval of regression coefficients. Regression coefficients represent the annual weight change (g/year) for $1 \mathrm{kcal} / \mathrm{g}$ ED. The overall estimate was based on random-effect model.

* Adjusted for follow-up time and baseline age, height and weight, smoking, physical activity, education, alcohol intake, menopausal status, hormone replace therapy use, and energy intake from beverages.

Figure 6-1. Association of energy density with annual weight change $(n=89,432)^{*}$.

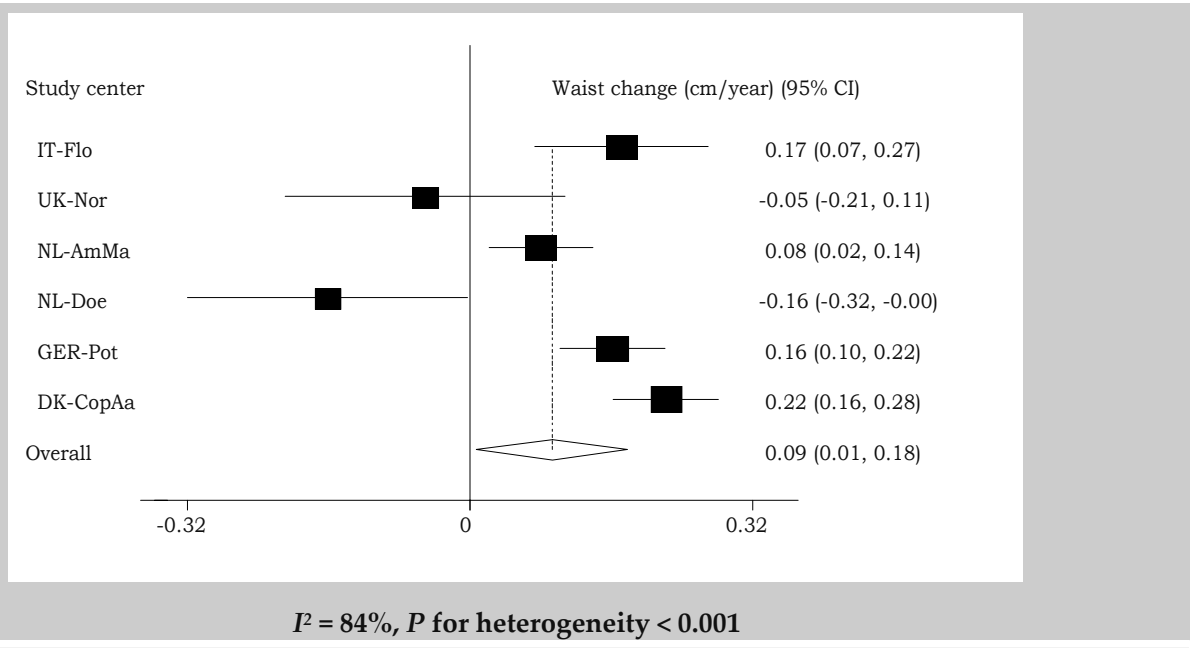

95\% CI: 95\% Confidence interval of regression coefficients. Regression coefficients represent the annual waist circumference change (cm/year) for $1 \mathrm{kcal} / \mathrm{g}$ ED. The overall estimate was based on random-effect model.

* Adjusted for follow-up time and baseline age, height, weight, and waist circumference, smoking, physical activity, education, alcohol intake, menopausal status, hormone replace therapy use, and energy intake from beverages.

Figure 6-2. Association of energy density with annual waist circumference change $(n=89,432)^{*}$.

those who were overweight or obese. The differences in the other study centers were less evident. For the associations with waist circumference change, the most evident 
differences were observed in IT-Flo and NL-Doe. The associations in participants with BMI $<25 \mathrm{~kg} / \mathrm{m}^{2}$ were much stronger, in the positive direction, than the associations in those who were overweight or obese. Overall, $1 \mathrm{kcal} / \mathrm{g}$ ED was associated with a waist circumference change of $0.17 \mathrm{~cm} /$ year [ $95 \%$ CI: $0.09,0.25$ ] and

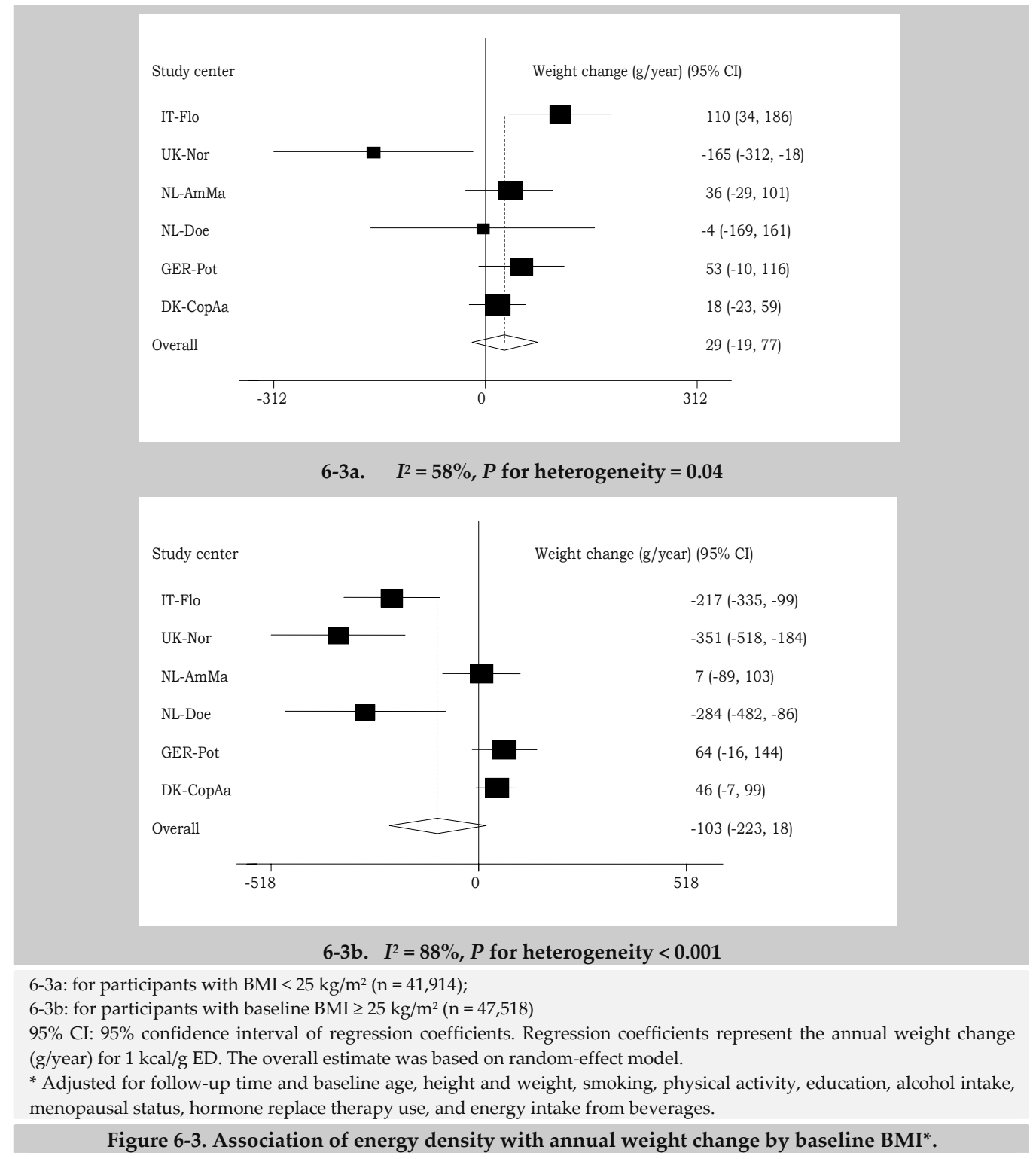

$0.04 \mathrm{~cm} /$ year [95\% CI: $-0.10,0.18$ ] respectively in participants with BMI $<25 \mathrm{~kg} / \mathrm{m}^{2}$ (Figure 6-4a) and those with $\mathrm{BMI} \geq 25 \mathrm{~kg} / \mathrm{m}^{2}$ (Figure 6-4b). 
Associations remained essentially similar in all sensitivity analyses performed, including use un-calibrated dietary variables; use corrected anthropometric variables; exclude participants who developed type 2 diabetes, cancer, or CVD during followup; and additionally adjust for individual food or nutrient variables which potentially mediate the effects of ED on weight and waist circumference change (results not shown).

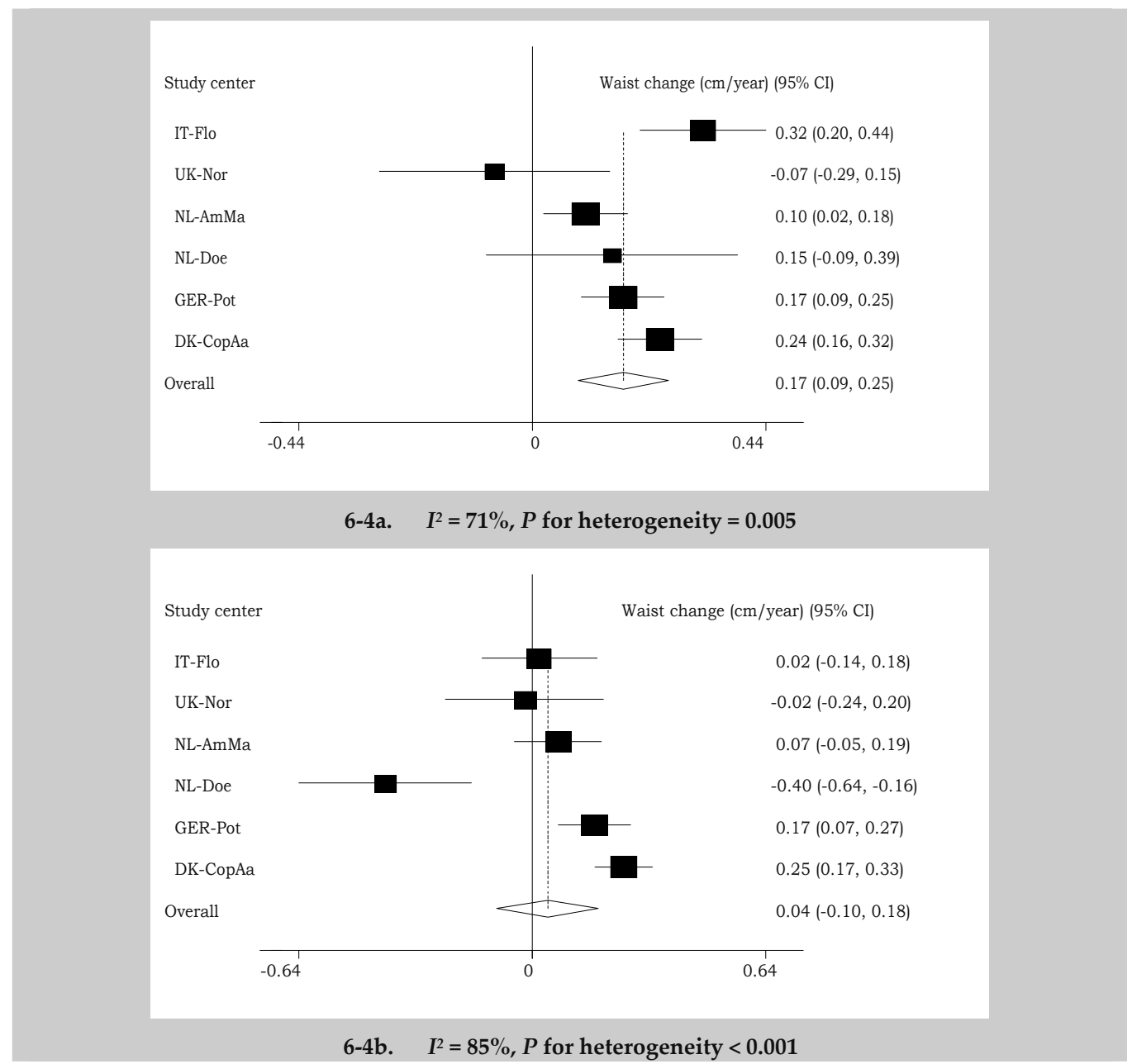

6-4a: for participants with BMI $<25 \mathrm{~kg} / \mathrm{m}^{2}(\mathrm{n}=41,914)$

6-4b: for participants with baseline BMI $\geq 25 \mathrm{~kg} / \mathrm{m}^{2}(\mathrm{n}=47,518)$

95\% CI: $95 \%$ confidence interval of regression coefficients. Regression coefficients represent the annual waist circumference change ( $\mathrm{cm} /$ year) for $1 \mathrm{kcal} / \mathrm{g}$ ED. The overall estimate was based on random-effect model.

* Adjusted for follow-up time and baseline age, height, weight, and waist circumference, smoking, physical activity, education, alcohol intake, menopausal status, hormone replace therapy use, and energy intake from beverages.

Figure 6-4. Association of energy density with annual waist circumference change by baseline BMI* 
Discussion

In this large multi-center prospective cohort study, we observed that a diet with a lower ED was associated with a lower intake of sugar and fats and a higher intake of fruits and vegetables. Higher ED was not associated with weight change but was positively associated with waist circumference change.

The main strengths of our study are the large sample size and variation in dietary intake based on participants from five European countries, and the availability of information on important confounding variables and predictors of weight or waist circumference change such as physical activity, education level, changes in smoking status, menopausal status and HRT use. Some differences in methodologies used to collect anthropometric data at follow-up (weight and waist circumference were selfreported instead of measured in four out of six centers) might have affected the results. However, in additional analyses, we corrected anthropometrics for clothing differences and self-reporting using previously developed methods in the EPIC study, ${ }^{24}$ but the associations of ED with changes in weight and waist circumference remained unchanged. We therefore opted to use the original uncorrected data in our analyses. Using FFQs to assess ED might be another limitation of the current study because FFQs, based on self-report of habitual food intake, may have inherent measurement error as well as bias from conscious or sub-conscious under-reporting or possible over-reporting of some food items. We addressed this in two ways. First, we used standardized 24-hour recall data to calibrate the FFQ measurements, thereby reducing potential measurement error. In addition, we also compared ED measured by the FFQ used in the two Dutch centers (NL-AmMa and NL-Doe) and the ED derived from the weighted average of multiple 24-hour recalls in a preliminary study. Spearman correlation coefficient was 0.64 in men and 0.56 in women (unpublished data), which indicated a good validity of the ED values measured by this FFQ. ${ }^{25,26}$

No clear consensus has been reached yet on the calculation of ED. A previous review of the literature identified 13 different calculation methods which mostly differed in the inclusion or exclusion of drinks, including free water, alcoholic beverages, energy-containing beverages, juice and milk.12, 16, 27 In the present study, we a priori decided to use the calculation method based on foods only but not drinks. ${ }^{28}$ Beverages add more weight than energy to diets, thereby lowering ED disproportionately. Furthermore, energy from drinks has only transient effects on satiation and does not influence habitual energy intake ${ }^{29}$. Also, beverage intake is highly variable and difficult to be estimated by any habitual diet assessment method. Previous studies indicated that including drinks into the ED calculation would dilute the associations of ED with both energy intake and changes of weight and waist circumference. ${ }^{16,30}$ When comparing the mean ED of our study population with that of other populations calculated using a similar method, the average ED in the current study lies between the population average of Japan $(1.4 \mathrm{kcal} / \mathrm{g})$ and the US $(1.9 \mathrm{kcal} / \mathrm{g}$ in men and $1.8 \mathrm{kcal} / \mathrm{g}$ in women). ${ }^{6,28}$ 
The relationships of ED with energy, food and nutrient intake found in the current study are in agreement with previous findings.1, 13,31,32 This may imply a high quality profile of diets with a lower ED because diets lower in glycemic index and glycemic load, containing higher amounts of fruits, vegetables and fiber and lower amounts of sugar and fats, especially saturated fatty acids, are generally believed to be favorable for promoting human health. ${ }^{4,33-35}$ It also provides a way for reducing $\mathrm{ED}$, by consuming more fruits and vegetables and reducing sugar and fat consumption.

The mechanism linking higher ED diet consumption and large gain in weight and waist circumference was speculated through increasing total energy intake. Therefore, we did not adjusted for total energy in our main analyses. However, when energy intake was added in the models in additional analyses, the association of ED with weight and waist circumference change was not essentially changed. This indicates that other aspects than lowering energy intake, such as reducing fat storage, is responsible for the observed effects. Furthermore, additional adjustment for individual nutrient factor such as total fat, saturated fatty acids, fiber, glycemic index or glycemic load did not alter the associations either. This may suggest that lower ED reflects a healthy dietary pattern rather than any individual dietary component.

The absence of an association between ED and weight change in our current study are at variance with other prospective cohort studies that observed a positive association between ED and weight change. For example, in a longitudinal study of 186 women in the US, women with higher ED gained more weight than women with lower ED (6.4 kg vs. $2.5 \mathrm{~kg}$ over 6 years). ${ }^{10}$ In two prospective studies among British children, a positive association between ED and body fat mass gain has been observed. ${ }^{13,30}$ In the Nurses' Health Study II, women who increased their dietary ED during follow-up the most (5th quintile) had a significantly greater weight gain than did those who decreased their dietary ED (1st quintile) $(6.42 \mathrm{~kg}$ vs. $4.57 \mathrm{~kg}$ over 8 years). However, weight gain was not different between women who maintained a lower ED and women who maintained a higher ED during follow-up. ${ }^{11}$ This latter non-significant finding was in accordance with the finding in the MONICA study ${ }^{12}$ and our current study. As explained by the authors, participants with a constantly higher ED might compensate for the energy intake from higher ED diet. The weight gain for those participants may have already reached a steady state after long-term consumption of a higher ED diet.11 However, since the habitual diets of participants have only been measured once at baseline, it impossible to clarify this issue in the current study. Another difference between the current study and the previous studies is the wide age range of participants (20-78 years at baseline). Despite the fact that no interaction with age was found, it is possible that the speed of weight gain slowed down in older participants.

This prospective cohort study showed a positive overall association between ED and waist circumference change, which was not addressed in the abovementioned studies. ${ }^{10-13}$ Although the association was rather weak, a waist circumference change 
of $0.09 \mathrm{~cm} /$ year represents approximately $12 \%$ of the mean waist circumference change in this study population. Abdominal obesity, measured by waist circumference, is a more accurate predictor of cardio-metabolic risk than general obesity measured by BMI, probably because it more closely reflects body fatness. ${ }^{36}$ The large variation in the annual waist circumference change $(\mathrm{SD}=1.26 \mathrm{~cm} / \mathrm{year}$ ) may be partly responsible for the small magnitude observed. Because of the small average waist circumference change $(0.76 \mathrm{~cm} /$ year $)$ as compared to the large variation, it is impossible to detect a stronger association. ${ }^{37}$ The weak association between ED and waist circumference, and the absence of an association between ED and weight change, could also be due to selective underreporting, which means underreporting of unhealthy foods and over-reporting of healthy ones. ${ }^{38}$ This is a common problem in epidemiological studies and compromises the accuracy of habitual dietary intake data, especially among overweight or obese individuals. ${ }^{39}$ This is in line with our findings that the ED was in the direction of positively associated with weight change in those participants with a healthy BMI at baseline, whereas was inversely in overweight or obese participants. Furthermore, there is evidence that underreporting is less waist-related than weight-related, ${ }^{40}$ which may be due to the higher awareness of the importance of a healthy BMI than a healthy waist circumference. Therefore the association between ED and waist circumference change may be less biased by the under-reporting.

The high amount of heterogeneity observed in the current study, especially the unexpected inverse association between ED and changes in weight and waist circumference in UK-Nor and NL-Doe where the follow-up anthropometrics were measured, may also be related to underreporting. That is because we observed a smaller heterogeneity across study centers in those participants who had a healthy baseline BMI than in those participants who were overweight or obese at baseline. More importantly, the inverse associations between ED and changes in weight and waist circumference in UK-Nor and NL-Doe became less inverse or positive in participants who were not overweight at baseline. The heterogeneity could also be due to the differences in source population between study centers. For example, in IT-Flo, participants include a sample of the general population and women participating in a breast cancer screening program. The UK-Nor cohort comes from general practitioners in the Norfolk region. ${ }^{41}$ In NL-Doe, respondents from a preexisting cardiovascular disease risk factor monitoring project were invited. ${ }^{42}$ Although in general there is no reason to assume a priori that these cohorts are different with respect to the association under study, subtle differences in underreporting of dietary intake, possibility of altering eating habits during followup, and health conscious among sub-groups may exist.

In conclusion, the findings of the current study suggests that diets with a lower ED, characterized by higher intake of fruits and vegetables and lower intake of sugar and fat, are not associated with weight gain but may have a beneficial, albeit weak, effect on the prevention of abdominal obesity. 


\section{References}

1. Ledikwe JH, Blanck HM, Kettel Khan L, et al. Dietary energy density is associated with energy intake and weight status in US adults. Am J Clin Nutr. 2006;83(6):1362-1368.

2. Prentice AM, Poppitt SD. Importance of energy density and macronutrients in the regulation of energy intake. Int J Obes Relat Metab Disord. 1996;20 Suppl 2:S18-23.

3. WHO/FAO. Diet, nutrition and the prevention of chronic diseases: report of a joint WHO/FAO expert consultation. Geneva 2003.

4. US Department of Agriculture. Nutrition and your health: dietary guidelines for Americans.: Washington DC; 2005.

5. McCrory MA, Saltzman E, Rolls BJ, et al. A twin study of the effects of energy density and palatability on energy intake of individual foods. Physiol Behav. 2006;87(3):451-459.

6. Murakami K, Sasaki S, Takahashi Y, et al. Dietary energy density is associated with body mass index and waist circumference, but not with other metabolic risk factors, in free-living young Japanese women. Nutrition. 2007;23(11-12):798-806.

7. Ello-Martin JA, Roe LS, Ledikwe JH, et al. Dietary energy density in the treatment of obesity: a yearlong trial comparing 2 weight-loss diets. Am J Clin Nutr. 2007;85(6):1465-1477.

8. Ledikwe JH, Rolls BJ, Smiciklas-Wright $\mathrm{H}$, et al. Reductions in dietary energy density are associated with weight loss in overweight and obese participants in the PREMIER trial. Am J Clin Nutr. 2007;85(5):1212-1221.

9. Rolls BJ, Roe LS, Beach AM, et al. Provision of foods differing in energy density affects long-term weight loss. Obes Res. 2005;13(6):1052-1060.

10. Savage JS, Marini M, Birch LL. Dietary energy density predicts women's weight change over 6 y. Am J Clin Nutr. 2008;88(3):677-684.

11. Bes-Rastrollo M, van Dam RM, Martinez-Gonzalez MA, et al. Prospective study of dietary energy density and weight gain in women. Am J Clin Nutr. 2008;88(3):769-777.

12. Iqbal SI, Helge JW, Heitmann BL. Do energy density and dietary fiber influence subsequent 5-year weight changes in adult men and women? Obesity (Silver Spring). 2006;14(1):106-114.

13. Johnson L, Mander AP, Jones LR, et al. A prospective analysis of dietary energy density at age 5 and 7 years and fatness at 9 years among UK children. Int J Obes (Lond). 2008;32(4):586-593.

14. Saris WH, Harper A. DiOGenes: a multidisciplinary offensive focused on the obesity epidemic. Obes Rev. 2005;6(2):175-176.

15. Riboli E, Hunt KJ, Slimani N, et al. European Prospective Investigation into Cancer and Nutrition (EPIC): study populations and data collection. Public Health Nutr. 2002;5(6B):1113-1124.

16. Ledikwe JH, Blanck HM, Khan LK, et al. Dietary energy density determined by eight calculation methods in a nationally representative United States population. J Nutr. 2005;135(2):273-278.

17. Ferrari P, Day NE, Boshuizen HC, et al. The evaluation of the diet/disease relation in the EPIC study: considerations for the calibration and the disease models. Int J Epidemiol. 2008;37(2):368-378.

18. Slimani N, Kaaks R, Ferrari $P$, et al. European Prospective Investigation into Cancer and Nutrition (EPIC) calibration study: rationale, design and population characteristics. Public Health Nutr. 2002;5(6B):1125-1145.

19. Slimani N, Deharveng G, Charrondiere RU, et al. Structure of the standardized computerized 24-h diet recall interview used as reference method in the 22 centers participating in the EPIC project. European Prospective Investigation into Cancer and Nutrition. Computer methods and programs in biomedicine. 1999;58(3):251-266.

20. Slimani N, Deharveng G, Unwin I, et al. The EPIC nutrient database project (ENDB): a first attempt to standardize nutrient databases across the 10 European countries participating in the EPIC study. Eur J Clin Nutr. 2007;61(9):1037-1056.

21. Kien CL, Ugrasbul F. Prediction of daily energy expenditure during a feeding trial using measurements of resting energy expenditure, fat-free mass, or Harris-Benedict equations. Am J Clin Nutr. 2004;80(4):876-880. 
22. Rinaldi S, Key TJ, Peeters PH, et al. Anthropometric measures, endogenous sex steroids and breast cancer risk in postmenopausal women: a study within the EPIC cohort. Int I Cancer. 2006;118(11):2832-2839.

23. Brustad M, Skeie G, Braaten $T$, et al. Comparison of telephone vs face-to-face interviews in the assessment of dietary intake by the $24 \mathrm{~h}$ recall EPIC SOFT program--the Norwegian calibration study. Eur J Clin Nutr. 2003;57(1):107-113.

24. Haftenberger M, Lahmann PH, Panico S, et al. Overweight, obesity and fat distribution in 50- to 64year-old participants in the European Prospective Investigation into Cancer and Nutrition (EPIC). Public Health Nutr. 2002;5(6B):1147-1162.

25. Molag ML, de Vries JH, Ocke MC, et al. Design characteristics of food frequency questionnaires in relation to their validity. Am J Epidemiol. 2007;166(12):1468-1478.

26. Willett WC. Future directions in the development of food-frequency questionnaires. Am J Clin Nutr. 1994;59(1 Suppl):171S-174S.

27. Cox DN, Mela DJ. Determination of energy density of freely selected diets: methodological issues and implications. Int J Obes Relat Metab Disord. 2000;24(1):49-54.

28. Mendoza JA, Drewnowski A, Christakis DA. Dietary energy density is associated with obesity and the metabolic syndrome in U.S. adults. Diabetes Care. 2007;30(4):974-979.

29. Westerterp-Plantenga MS. Analysis of energy density of food in relation to energy intake regulation in human subjects. Br J Nutr. 2001;85(3):351-361.

30. McCaffrey TA, Rennie KL, Kerr MA, et al. Energy density of the diet and change in body fatness from childhood to adolescence; is there a relation? Am J Clin Nutr. 2008;87(5):1230-1237.

31. Kant AK, Graubard BI. Energy density of diets reported by American adults: association with food group intake, nutrient intake, and body weight. Int J Obes (Lond). 2005;29(8):950-956.

32. Stookey JD. Energy density, energy intake and weight status in a large free-living sample of Chinese adults: exploring the underlying roles of fat, protein, carbohydrate, fiber and water intakes. Eur J Clin Nutr. 2001;55(5):349-359.

33. Mozaffarian D, Rimm EB. Fish intake, contaminants, and human health: evaluating the risks and the benefits. Jama. 2006;296(15):1885-1899.

34. Howard BV, Manson JE, Stefanick ML, et al. Low-fat dietary pattern and weight change over 7 years: the Women's Health Initiative Dietary Modification Trial. Jama. 2006;295(1):39-49.

35. Ludwig DS. Clinical update: the low-glycaemic-index diet. Lancet. 2007;369(9565):890-892.

36. Janssen I, Katzmarzyk PT, Ross R. Body mass index, waist circumference, and health risk: evidence in support of current National Institutes of Health guidelines. Arch Intern Med. 2002;162(18):2074-2079.

37. Ma Y, Olendzki B, Chiriboga D, et al. Association between dietary carbohydrates and body weight. Am J Epidemiol. 2005;161(4):359-367.

38. Goris AH, Westerterp-Plantenga MS, Westerterp KR. Undereating and underrecording of habitual food intake in obese men: selective underreporting of fat intake. Am J Clin Nutr. 2000;71(1):130-134.

39. Macdiarmid J, Blundell J. Assessing dietary intake: Who, what and why of under-reporting. Nutrition Research Reviews. 1998;11(2):231-253.

40. Mattisson I, Wirfalt E, Aronsson CA, et al. Misreporting of energy: prevalence, characteristics of misreporters and influence on observed risk estimates in the Malmo Diet and Cancer cohort. $\mathrm{Br} \mathrm{J}$ Nutr. 2005;94(5):832-842.

41. Day N, Oakes S, Luben R, et al. EPIC-Norfolk: study design and characteristics of the cohort. European Prospective Investigation of Cancer. Br J Cancer. 1999;80 Suppl 1:95-103.

42. Verschuren WM, Blokstra A, Picavet HS, et al. Cohort profile: the Doetinchem Cohort Study. Int J Epidemiol. 2008;37(6):1236-1241. 



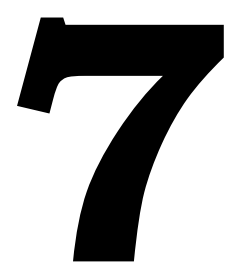

\title{
Fiber intake in relation to subsequent changes of weight and waist circumference in European men and women
}

\author{
H. Du, D. L. van der A, H. C. Boshuizen, N. G. Forouhi, \\ N. J. Wareham, J. Halkjær, A. Tjønneland, M. Uhre Jakobsen, \\ K. Overvad, B. Buijsse, H. Boeing, D. Palli, G. Masala, \\ T. I.A. Sørensen, W. H.M.Saris, E. J.M. Feskens.
}

Am J Clin Nutr. In review.

\begin{abstract}
Background: Dietary fiber may play a role in obesity prevention. So far, the role of fiber from different sources in weight change has rarely been studied.

Objective: To investigate the association of total dietary fiber, cereal fiber, and fruit and vegetable fiber with changes of weight and waist circumference.

Design: We conducted a prospective cohort study with 89,432 European participants, aged 20-78 years, free of cancer, CVD and diabetes at baseline, and followed for an average of 6.5 years. Dietary information was collected using validated country specific food frequency questionnaires. Multiple linear regression analysis was performed in each center and estimates were combined using random effect metaanalyses. Adjustments were made for baseline anthropometric, demographic and lifestyle factors, follow-up duration and other dietary variables.

Results: Total fiber was inversely associated with subsequent weight and waist change. For a $10 \mathrm{~g} /$ day higher total fiber intake, the pooled estimate was $-39 \mathrm{~g} /$ year [95\% confidence interval (CI): -71, -7] for weight change and $-0.08 \mathrm{~cm} /$ year [95\% CI: $0.11,-0.05]$ for waist change. A $10 \mathrm{~g} /$ day higher fiber intake from cereals was associated with $-77 \mathrm{~g} /$ year [95\% CI: $-127,-26]$ weight change and $-0.10 \mathrm{~cm} /$ year [ $95 \%$ CI: -0.18, -0.02] waist change. Fruit and vegetable fiber was not associated with weight change, but had a similar association with waist change as compared to total dietary fiber and cereal fiber intake.

Conclusion: Our results may support a beneficial role of higher intake of dietary fiber, especially cereal fiber, on preventing body weight and waist circumference gain.
\end{abstract}




\section{Introduction}

Dietary fiber is defined as the edible parts of plant foods that are resistant to digestion and absorption in the human small intestine with complete or partial fermentation in the large intestine. It could facilitate body weight control through different physiological mechanisms. ${ }^{1}$ Firstly, fiber rich foods tend to be more satiating due to their relatively low energy density and palatability as compared to low fiber foods. Secondly, dietary fiber, especially soluble fiber, could increase the viscosity of diets and slow down the digestion, thus stimulate the release of gut hormones, such as cholecystokinin and glucagon-like peptide-1, and promote satiety. In addition, dietary fiber could provide a mechanical barrier to the enzymatic digestion of other macronutrients such as fat and starch in the small intestine. Moreover, the slower digestion and absorption rate of carbohydrates would lead to a reduced postprandial blood glucose response, which over a long term could improve insulin sensitivity and influence fuel partitioning to favor fat oxidation. ${ }^{1}$ Although not completely consistent, findings from well controlled intervention studies and large cohort studies support the beneficial role of dietary fiber on body weight regulation. For example, in a 24-week intervention study, the addition of dietary fiber to a low-calorie diet has significantly increased weight loss. ${ }^{2}$ In the Nurses' Health Study, women with higher increase in fiber intake have gained less body weight over 12 years. ${ }^{3}$ In the CARDIA study, high fiber intake has been associated with lower weight gain in 10 years. ${ }^{4}$

However, fiber is not a homogeneous entity and its physiological effects depend on several factors including its origin or sources. For example, in the Health Professionals Follow-up Study, it has been observed that cereal fiber is more strongly inversely associated with the risk of myocardial infarction than fruit and vegetable fiber. ${ }^{5}$ In a meta-analysis of nine cohort studies, a high intake of cereal fiber, but not fruit and vegetable fiber, was significantly associated with a reduced risk of type 2 diabetes. ${ }^{6}$ However, only one epidemiological study has compared the associations of fiber from different sources in relation to obesity so far, showing that increased intakes of fruit fiber and cereal fiber, but not vegetable fiber, were associated with less weight gain. ${ }^{7}$

To investigate whether the intake of dietary fiber, in total and by food sources, is associated with long-term weight and waist circumference change, we conducted the current study in a population-based prospective cohort of Europeans. With the data from five different countries, this study provides a large range in dietary exposures.

\section{Participants and Methods \\ Participants}

This study is a part of the DiOGenes project (acronym for "Diet, Obesity and Genes"), a multi-disciplinary European project targeting on obesity. Participants came from eight cities or counties within five European countries: Florence (Italy), 
Norfolk (UK), Amsterdam, Maastricht and Doetinchem (The Netherlands), Potsdam (Germany), and Copenhagen and Aarhus (Denmark), taking part in the pre-existing European Prospective Investigation into Cancer and Nutrition (EPIC). EPIC study has been approved by local review board of all participating institutions. Written informed consent has been obtained from all participants before joining EPIC study. Detailed information on the study population and data collection has been described elsewhere. ${ }^{8}$ Of the 146,543 men and women who took part in the baseline examination during 1992-1998, 102,346 (69.8\%) participated in the follow-up examination during 1998-2005. For the present study, the following exclusion criteria were applied: pregnancy at baseline or follow-up $(n=133)$, missing information on diet, anthropometrics or follow-up duration $(n=2,135)$, the ratio of energy intake (EI) to estimated basal metabolic rate (BMR) was in the top or bottom $1 \%$ of the entire EPIC population $(n=1,803)$, having unrealistic anthropometric measurements ( $\mathrm{n}=$ 331) and having chronic diseases including cancer, diabetes and CVD at baseline ( $\mathrm{n}=$ 8,512 ). In total, 89,432 participants, $42 \%$ men and $58 \%$ women, were included in the data analyses.

\section{Dietary assessments}

Country-specific validated food frequency questionnaires (FFQs) were selfadministered at baseline. Energy and nutrient intakes were calculated using countryspecific food composition tables. ${ }^{8}$ Regarding these food composition tables, the enzymatic-Gravimetric method adopted by the AOAC (Association of the Official Analytical Chemists) was used to define dietary fiber in countries except the UK, where dietary fiber was defined as non-starch polysaccharides (NSP) and was measured using the Englyst method.9, 10 For potatoes, legumes, cereals, cakes and biscuits, the AOAC value was re-calculated from the NSP value by multiplying 1.28 and subtracting 0.02. For vegetables, fruits and fruit- and vegetable-based products, the AOAC and NSP values were assumed comparable due to the low amount of lignin and the absence of resistant starch.

Total dietary fiber was the fiber intake from all foods and beverages. Validity of questionnaires on total fiber intake assessments has been documented previously. In short, the FFQs been validated against either 12 24-hour diet recalls (Italy, Germany and The Netherlands), 16 days weighted records (UK), or two times seven days of weighed diet records (Denmark). The validity coefficients ranged from 0.39 to $0.74 .{ }^{11-}$ ${ }_{13}$ Cereal fiber was calculated by summing the fiber intake from cereals and cereal products, which include rice, pasta, breads, biscuits, crackers, breakfast cereals and other products made of flour. Fruit and vegetable fiber was calculated as the sum of fiber intake from leafy vegetables, fruiting vegetables, root vegetables (excluding potatoes), cabbages, mushrooms, grain and pod vegetables, onion, garlic, stalk vegetables, sprouts, fruits, and olives. Contributions of individual food groups to the intake of cereal fiber and fruit and vegetable fiber by study center are presented in a supplementary table (S-Table 7-1). 
Dietary glycemic index (GI) was calculated as the weighted average of GI values (based on the EPIC GI database ${ }^{14}$ ) of carbohydrate-containing foods consumed daily and dietary glycemic load (GL) was calculated by multiplying the GI by the amount of total carbohydrate intake divided by 100 .

To improve the comparability of dietary data collected using different FFQs and to adjust for measurement errors, a linear calibration was performed using a single 24-hour dietary recall from a stratified random sample $(n=6,790)$ of the total EPIC participants as reference. ${ }^{15}$ These 24 -hour dietary recall data were collected using a software program (EPIC-SOFT) specifically designed to standardize the dietary measurements across European populations. Nutrient intake from these 24-hour recall data were standardized using the European Nutrient Database (ENDB) developed within the EPIC study.

Under-reporting of EI was estimated by EI:BMR $<1.1,^{16}$ where BMR was estimated using the Harris-Benedict equation. ${ }^{8}$

\section{Anthropometric measurements}

Information on body weight and waist circumference was collected at baseline and at the end of follow-up. Details of the methods used at baseline have been described previously. ${ }^{17}$ In short, all participants were measured by trained technicians for weight, height and waist circumference using standard study protocols. At follow-up, body weight and waist circumference of participants in Doetinchem (NL) and Norfolk (UK) were measured by trained technicians according to the same protocols as at baseline, while others provided self-reported weight and waist circumference. Annual changes in weight (g/year) and waist circumference ( $\mathrm{cm}$ /year) were calculated by follow-up value minus baseline value, divided by the total years of follow-up. Due to differences in methods used to collect anthropometric information at follow-up and the length of follow-up time, participants from Doetinchem were treated separately from those from Amsterdam and Maastricht, while participants from Copenhagen and Aarhus were combined because no such differences between these two groups existed. Thus, six study centers were identified, namely Florence (IT-Flo, $\mathrm{n}=8,266$ ), Norfolk (UK-Nor, $\mathrm{n}=$ 12,031), Amsterdam and Maastricht (NL-AmMa, $n=6,226$ ), Doetinchem (NL-Doe, $n$ $=3,964$ ), Potsdam (GER-Pot, $n=14,746$ ), and Copenhagen and Aarhus (DK-CopAa, $n$ $=33,804)$.

\section{Other covariates}

Information on lifestyle was collected via self-administered questionnaires. Questions covered age, gender, education level, physical activity, smoking, menopausal status, and use of hormone replace therapy (HRT). Information on health status, including CVD, cancer and type 2 diabetes, was collected using either questionnaires or disease registries. Physical activity level was based on occupational and recreational activities and participants were classified as either inactive, 
moderately inactive, moderately active, active, or unknown. Education level was indicated as the highest level of school achieved and participants were classified into primary school or less, technical-professional school, secondary school, university, or unknown. Using the information on smoking status at baseline and at follow-up, we classified participants into one of the following five categories: stable smoking, start smoking, quit smoking, not smoking, or unknown.

\section{Statistical methods}

The associations between fiber intake and changes in weight and waist circumference were examined using multivariable linear regression analyses. Centerspecific analyses were conducted, after which random effect meta-analyses were performed to detect heterogeneity among study centers $\left(I^{2}\right)$ and to calculate pooled estimates. This has the advantages of allowing for heterogeneity not only in the effect of the exposure but also the influence of the confounders, ${ }^{18}$ and also explicitly estimates the extent of heterogeneity and leads to a natural presentation of the results on a forest plot. Covariates included baseline age (years), gender, weight (kg), height $(\mathrm{cm})$ and waist circumference $(\mathrm{cm}$, for waist circumference change analyses only), smoking, physical activity, education level, follow-up duration (years), alcohol intake (non drinker, 0.1 - 4.9 g/day, 4.9 - 15 g/day, 15 - 30 g/day, 30 - 60 g/day, > 60 g/day), GI, and the intake of protein, fat and carbohydrates. Additionally, for women, analyses were also adjusted for menopausal status (postmenopausal yes/no) and hormone use (yes/no or unknown). Analyses of cereal fiber were also adjusted for fruit and vegetable fiber and fiber from other sources, such as potatoes, legumes and nuts. As fruit fiber and vegetable fiber had similar associations with weight and waist circumference change, they were combined into fruit and vegetable fiber. Analyses of fruit and vegetable fiber were also adjusted for cereal fiber and fiber from other sources. All dietary variables included in the analyses were calibrated and were adjusted for total energy intake using the residual method.

Interaction of fiber intake with age, gender, baseline BMI, smoking, duration of follow-up, and EI: BMR was investigated by introducing product terms into the model. A two-sided $P<0.05$ was considered statistically significant in the analyses of main effects, whereas $P<0.01$ in at least three, out of the six, study centers was considered statistically significant when testing for interaction.

Sensitivity analyses were performed for the main analyses, including using uncalibrated dietary variables, using anthropometrics correcting for clothing and selfreport, and excluding those participants who developed cancer, type 2 diabetes or CVD during follow-up. Except for the random effect meta-analyses, which were conducted using STATA 8.2 (StataCorp, Texas, USA), all other statistical analyses were performed using SAS 9.1 (SAS, Institute, Cary, NC).

\section{Results}




\begin{tabular}{|c|c|c|c|c|c|c|}
\hline \multicolumn{7}{|c|}{ Table 7-1. Description of study population $(n=89,432)$. } \\
\hline $\begin{array}{l}\text { Study } \\
\text { Center }\end{array}$ & \multicolumn{2}{|c|}{$\begin{array}{c}\text { Total fiber intake } \\
\text { (g/day) }\end{array}$} & \multicolumn{2}{|c|}{$\begin{array}{c}\text { Cereal fiber intake } \\
\text { (g/day) }\end{array}$} & \multicolumn{2}{|c|}{$\begin{array}{c}\text { Fruit and vegetable fiber } \\
\text { (g/day) }\end{array}$} \\
\hline & Men & Women & Men & Women & Men & Women \\
\hline IT-Flo & $27.1 \pm 5.5$ & $20.7 \pm 3.0$ & $10.4 \pm 2.2$ & $6.6 \pm 1.1$ & $11.7 \pm 2.6$ & $10.2 \pm 2.0$ \\
\hline UK-Nor & $20.5 \pm 2.9$ & $17.2 \pm 2.0$ & $8.4 \pm 1.6$ & $7.0 \pm 1.3$ & $5.6 \pm 1.9$ & $5.6 \pm 1.0$ \\
\hline NL-AmMa & $25.6 \pm 6.3$ & $20.6 \pm 4.4$ & $11.7 \pm 3.9$ & $8.0 \pm 2.7$ & $6.1 \pm 1.6$ & $6.5 \pm 2.2$ \\
\hline NL-Doe & $27.0 \pm 5.9$ & $21.0 \pm 5.1$ & $11.0 \pm 3.8$ & $7.9 \pm 2.6$ & $7.2 \pm 2.4$ & $6.9 \pm 2.7$ \\
\hline GER-Pot & $23.9 \pm 3.9$ & $21.0 \pm 3.2$ & $9.1 \pm 2.2$ & $7.0 \pm 1.3$ & $8.1 \pm 1.9$ & $8.8 \pm 2.2$ \\
\hline DK-CopAa & $26.3 \pm 5.3$ & $23.1 \pm 4.8$ & $15.7 \pm 3.8$ & $12.5 \pm 2.8$ & $6.4 \pm 2.7$ & $7.4 \pm 2.8$ \\
\hline \multirow[t]{3}{*}{ Overall } & $25.0 \pm 5.4$ & $21.3 \pm 4.4$ & $12.6 \pm 4.6$ & $9.3 \pm 3.5$ & $6.9 \pm 2.8$ & $7.7 \pm 2.7$ \\
\hline & \multicolumn{2}{|c|}{$\begin{array}{c}\text { Baseline BMI } \\
\left(\mathrm{kg} / \mathrm{m}^{2}\right)\end{array}$} & \multicolumn{2}{|c|}{$\begin{array}{c}\text { Baseline waist } \\
\text { circumference }(\mathrm{cm})\end{array}$} & \multicolumn{2}{|c|}{$\begin{array}{c}\text { Baseline age } \\
\text { (years) }\end{array}$} \\
\hline & Men & Women & Men & Women & Men & Women \\
\hline IT-Flo & $26.1 \pm 3.2$ & $25.0 \pm 3.9$ & $90 \pm 8.9$ & $77 \pm 9.5$ & $51 \pm 7.2$ & $52 \pm 7.7$ \\
\hline UK-Nor & $26.3 \pm 3.1$ & $25.8 \pm 4.0$ & $95 \pm 9.3$ & $81 \pm 10.1$ & $59 \pm 8.9$ & $58 \pm 8.9$ \\
\hline NL-AmMa & $25.5 \pm 3.4$ & $24.4 \pm 3.8$ & $91 \pm 10.4$ & $78 \pm 9.7$ & $43 \pm 10.4$ & $42 \pm 10.6$ \\
\hline NL-Doe & $26.0 \pm 3.0$ & $25.4 \pm 4.0$ & $95 \pm 9.0$ & $86 \pm 10.7$ & $46 \pm 9.7$ & $46 \pm 9.8$ \\
\hline GER-Pot & $26.7 \pm 3.4$ & $25.5 \pm 4.4$ & $94 \pm 9.6$ & $80 \pm 10.9$ & $52 \pm 7.8$ & $49 \pm 9.2$ \\
\hline DK-CopAa & $26.3 \pm 3.4$ & $25.4 \pm 4.2$ & $95 \pm 9.4$ & $81 \pm 10.7$ & $56 \pm 4.3$ & $56 \pm 4.4$ \\
\hline \multirow[t]{3}{*}{ Overall } & $26.3 \pm 3.3$ & $25.3 \pm 4.1$ & $94 \pm 9.6$ & $80 \pm 10.6$ & $54 \pm 8.2$ & $53 \pm 8.8$ \\
\hline & \multicolumn{2}{|c|}{$\begin{array}{c}\text { Weight change } \\
\text { (g/year) }\end{array}$} & \multicolumn{2}{|c|}{$\begin{array}{l}\text { Waist circumference } \\
\text { change (cm/year) }\end{array}$} & \multicolumn{2}{|c|}{$\begin{array}{c}\text { Follow-up duration } \\
\text { (years) }\end{array}$} \\
\hline & Men & Women & Men & Women & Men & Women \\
\hline IT-Flo & $128 \pm 554$ & $174 \pm 546$ & $0.75 \pm 0.7$ & $0.87 \pm 0.8$ & $9.4 \pm 1.1$ & $9.4 \pm 1.1$ \\
\hline UK-Nor & $362 \pm 1017$ & $383 \pm 1095$ & $0.22 \pm 1.5$ & $0.22 \pm 1.6$ & $3.7 \pm 0.7$ & $3.7 \pm 0.7$ \\
\hline NL-AmMa & $146 \pm 599$ & $177 \pm 624$ & $0.56 \pm 0.8$ & $0.69 \pm 0.8$ & $10.0 \pm 1.4$ & $9.9 \pm 1.5$ \\
\hline NL-Doe & $433 \pm 833$ & $447 \pm 939$ & $0.59 \pm 1.0$ & $0.56 \pm 1.4$ & $5.0 \pm 0.2$ & $5.0 \pm 0.2$ \\
\hline GER-Pot & $146 \pm 613$ & $205 \pm 648$ & $0.64 \pm 0.7$ & $0.84 \pm 0.8$ & $8.7 \pm 0.8$ & $8.6 \pm 0.8$ \\
\hline DK-CopAa & $-25 \pm 832$ & $-72 \pm 841$ & $0.51 \pm 1.2$ & $1.33 \pm 1.5$ & $5.4 \pm 0.3$ & $5.4 \pm 0.3$ \\
\hline Overall & $109 \pm 817$ & $119 \pm 823$ & $0.51 \pm 1.1$ & $0.94 \pm 1.3$ & $6.2 \pm 2.2$ & $6.6 \pm 2.3$ \\
\hline
\end{tabular}

Participants had a mean age of 53 years (range: 20-78 years) at baseline and were followed for an average of 6.5 years (range: 1.9-12.5 years). Fiber consumption varied across study centers and between genders (Table 7-1). Total dietary fiber intake was the lowest in UK-Nor (20.5 g/day and $17.2 \mathrm{~g} /$ day for men and women respectively). Danish participants had the highest cereal fiber consumption (15.7 g/day for men and $12.5 \mathrm{~g} /$ day for women), while Italian participants had the highest fruit and vegetable fiber intake (11.7 g/day for men and $10.2 \mathrm{~g} /$ day for women). Annual weight change was higher in NL-Doe (433 g/day for men and $447 \mathrm{~g} /$ year for women) and UK-Nor (362 g/year for men and $383 \mathrm{~g} /$ year for women) than in other centers. Annual waist circumference change was the lowest in UK-Nor $(0.22 \mathrm{~cm} /$ year $)$ and highest in men from IT-Flo $(0.75 \mathrm{~cm} /$ year) and women from DK-CopAa (1.33 
cm/year). Baseline BMI was similar except in NL-AmMa, where participants' BMI was about $1 \mathrm{~kg} / \mathrm{m}^{2}$ lower.

\begin{tabular}{|c|c|c|c|c|c|c|c|}
\hline \multicolumn{8}{|c|}{$\begin{array}{l}\text { Table 7-2. Characteristics by quintiles of cereal fiber } \\
\qquad(\mathrm{n}=89,432)^{*} .\end{array}$} \\
\hline & \multirow[t]{2}{*}{ Overall } & \multicolumn{3}{|c|}{ By cereal fiber } & \multicolumn{3}{|c|}{$\begin{array}{l}\text { By fruit \& vegetable } \\
\text { fiber }\end{array}$} \\
\hline & & Q1 & Q3 & Q5 & Q1 & Q3 & Q5 \\
\hline Total fiber intake, $g / d$ & $22.8 \pm 5.2$ & 18.4 & 22.2 & 28.9 & 19.9 & 22.8 & 26.6 \\
\hline Cereal fiber intake, $g / d$ & $10.7 \pm 4.3$ & 5.9 & 9.9 & 17.5 & 11.5 & 10.8 & 10.2 \\
\hline Fruit \& vegetable fiber intake, $g / d$ & $7.4 \pm 2.8$ & 7.9 & 7.2 & 7.0 & 4.0 & 7.0 & 11.6 \\
\hline Baseline age, yrs & $53 \pm 8.6$ & 52 & 53 & 55 & 53 & 53 & 53 \\
\hline Gender, \% men & 42 & 13 & 44 & 71 & 55 & 42 & 32 \\
\hline Follow-up duration, yrs & $6.5 \pm 2.2$ & 7.5 & 6.5 & 5.6 & 5.4 & 6.5 & 7.6 \\
\hline Baseline weight, $k g$ & $73.4 \pm 13.5$ & 69.0 & 73.9 & 77.6 & 75.2 & 73.7 & 71.9 \\
\hline Baseline BMI, $\mathrm{kg} / \mathrm{m}^{2}$ & $25.7 \pm 3.8$ & 26.1 & 25.7 & 25.5 & 25.9 & 25.6 & 25.7 \\
\hline Overweight $^{\dagger}, \%$ & 41 & 41 & 41 & $41 \ddagger$ & 43 & 40 & 40 \\
\hline Obesity§, \% & 12 & 15 & 12 & 10 & 13 & 12 & 12 \\
\hline Baseline waist, $\mathrm{cm}$ & $86.2 \pm 12.3$ & 82.6 & 86.6 & 89.8 & 88.8 & 86.3 & 84.1 \\
\hline Total energy intake, kcal/day & $2200 \pm 460$ & 1828 & 2211 & 2594 & 2234 & 2217 & 2196 \\
\hline Fat, en $\%$ & $35.6 \pm 3.6$ & 34.6 & 35.5 & 37.0 & 35.9 & 36.1 & 34.7 \\
\hline Protein, $e n \%$ & $15.1 \pm 1.4$ & 15.7 & 15.1 & 14.5 & 15.1 & 14.9 & 15.3 \\
\hline Carbohydrates, en \% & $43.1 \pm 4.4$ & 44.9 & 42.6 & 41.6 & 40.8 & 42.7 & 45.6 \\
\hline Glycemic index\| & $57 \pm 2.6$ & 55 & 57 & 59 & 59 & 57 & 55 \\
\hline Glycemic load\| & $134 \pm 29$ & 113 & 134 & 158 & 133 & 134 & 139 \\
\hline Smoking status, \% nonsmokers & 71 & 74 & 71 & 66 & 60 & 73 & 77 \\
\hline Education, \% university & 23 & 19 & 24 & 26 & 16 & 26 & 25 \\
\hline Physical activity, \% active & 26 & 15 & 26 & 40 & 27 & 25 & $28 \ddagger$ \\
\hline Post-menopausal womenII, \% & 57 & 34 & 59 & 74 & 52 & 56 & 62 \\
\hline Hormone-use women II, \% & 21 & 13 & 21 & 28 & 21 & 22 & 20 \\
\hline \multicolumn{8}{|c|}{$\begin{array}{l}\text { * Values presented are mean } \pm \text { standard deviation, mean or percentages. } P \text { for trend } \\
\text { linear regression (continuous variables) or logistic regression (categorical variables) } \\
{ }^{+} 25 \mathrm{~kg} / \mathrm{m}^{2} \leq \mathrm{BMI}<30 \mathrm{~kg} / \mathrm{m}^{2} \ddagger P \text { for trend }>0.05 \text {, all others } P<0.05 \S \mathrm{BMI} \geq 30 \mathrm{~kg} / \mathrm{m}^{2} \\
\end{array}$} \\
\hline
\end{tabular}

Participants in the higher quintile of cereal fiber intake had higher total fiber intake and lower fruit and vegetable fiber intake (Table 7-2). Likewise, with increasing intake of fruit and vegetable fiber, total fiber intake increased but cereal fiber intake decreased. Participants with higher cereal fiber intake were more often men, more often smokers, more physically active and had a higher level of education. Participants with higher fruit and vegetable fiber intake were more often women, often non-smokers and also had a higher education level. Dietary GI increased with the increase of cereal fiber, but decreased with the increase of fruit and vegetable fiber. 
None of the potential effect modifiers investigated, including gender, age, baseline BMI, smoking, duration of follow-up, and EI:BMR, altered the association between fiber and annual changes of weight and waist circumference. Therefore, men and women were combined in the subsequent analyses.

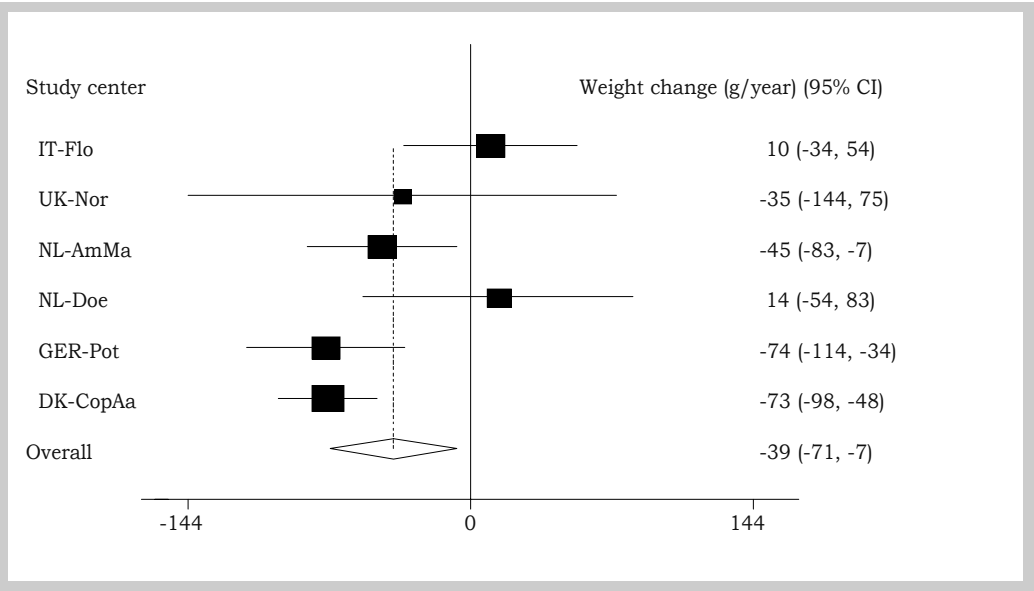

7-1a. $\quad I^{2}=67 \%, P$ for heterogeneity $=0.01$

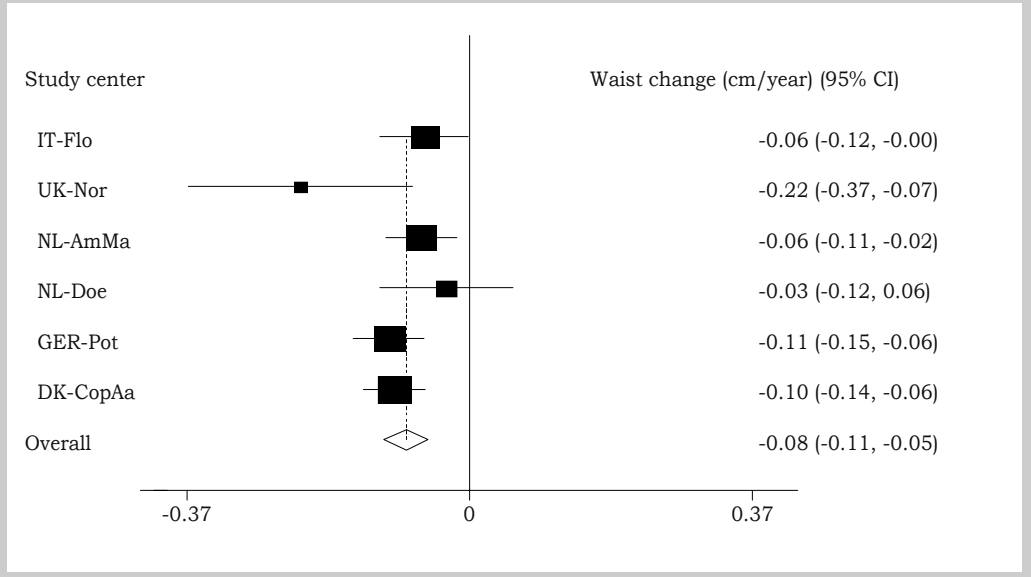

7-1b. $\quad I^{2}=35 \%, P$ for heterogeneity $=0.2$

* Values presented are regression coefficients $(95 \% \mathrm{CI})$ of a $10 \mathrm{~g}$ /day total fiber intake with weight (7-1a) and waist circumference (7-1b) change.

Analyses were adjusted for baseline age, weight and height, gender, smoking, education, physical activity, follow-up duration, alcohol consumption, the intake of fat, carbohydrates, protein, glycemic index, and, for women, menopausal status and use of hormone replacement therapy. For waist circumference change analyses, baseline waist circumference was also adjusted for. Overall estimates were based on random effect models.

Figure 7-1. Associations between total fiber intake and changes in weight and waist circumference*.

After the adjustment for potential confounders, total dietary fiber intake was inversely associated with annual weight change in four out of six study centers. When the effects in six study centers were combined, $10 \mathrm{~g} /$ day of total dietary fiber 
intake was associated with an annual weight change of $-39 \mathrm{~g} /$ year [95\% confidence interval (CI): -71, -7] (Figure 7-1a). This amount of weight change corresponds to a BMI change of about $0.013 \mathrm{~kg} / \mathrm{m}^{2}$ in our study population (mean height $=1.69$ meter).

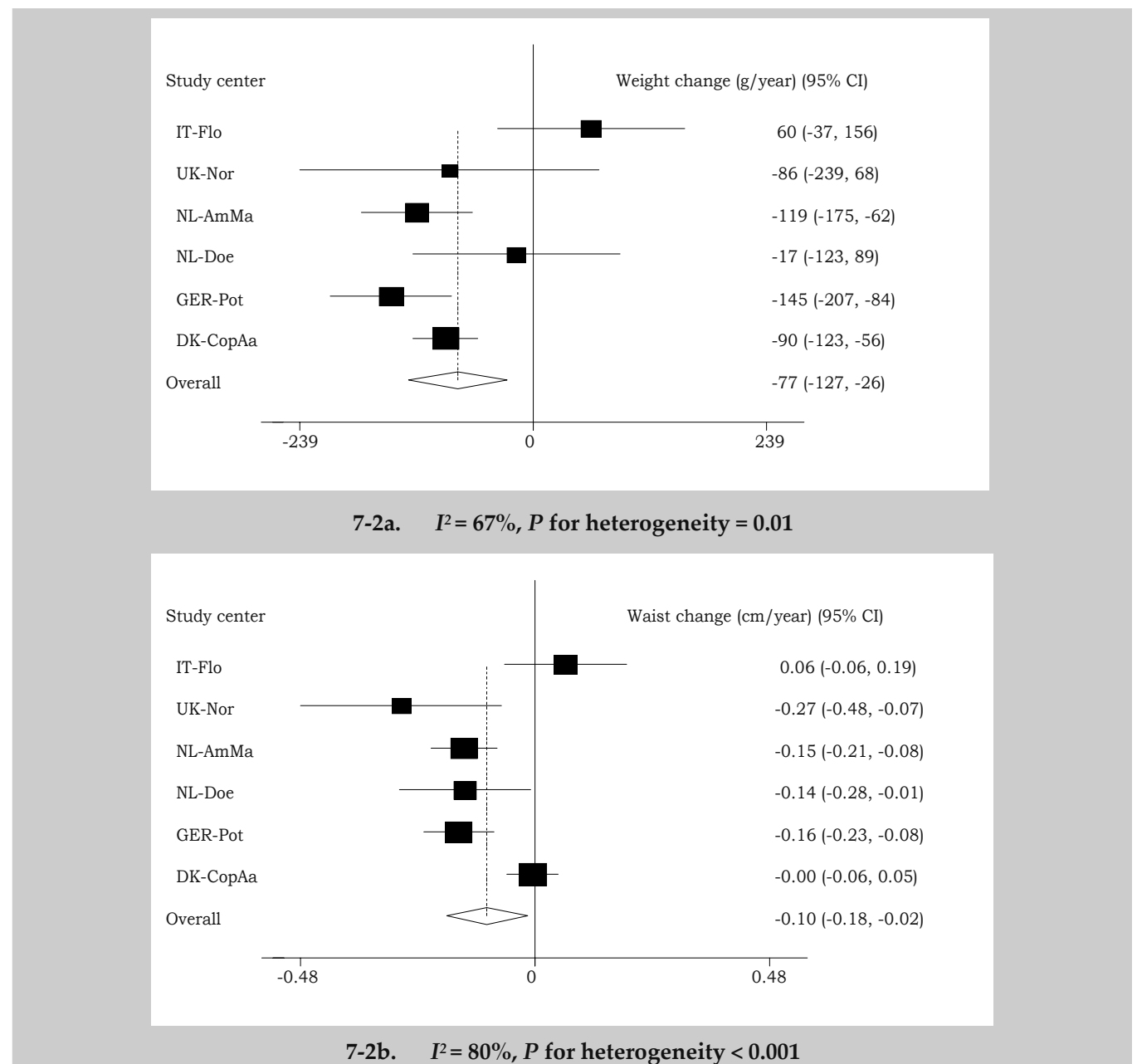

* Values presented are regression coefficients $(95 \% \mathrm{CI})$ of a $10 \mathrm{~g} /$ day cereal fiber intake with weight $(7-2 \mathrm{a})$ and waist circumference (7-2b) change.

Analyses were adjusted for baseline age, weight and height, gender, smoking, education, physical activity, follow-up duration, alcohol consumption, the intake of fat, carbohydrates, protein, glycemic index, fruit and vegetable fiber, fiber from other sources, and, for women, menopausal status and use of hormone replacement therapy. For waist circumference change analyses, baseline waist circumference was also adjusted for. Overall estimates were based on random effect models.

Figure 7-2. Associations between cereal fiber intake and changes in weight and waist circumference*.

A significant amount of heterogeneity was observed $\left(I^{2}=67 \%, P\right.$ for heterogeneity $=$ 0.01). In addition, total dietary fiber intake was inversely associated with waist circumference change in all study centers. For $10 \mathrm{~g} /$ day of total dietary fiber, the 
annual waist circumference change was $-0.08 \mathrm{~cm} /$ year [95\% CI: $-0.11,-0.05]$. The heterogeneity across study centers was not significant $\left(I^{2}=35 \%, P\right.$ for heterogeneity $=$ 0.2) (Figure 7-1b).

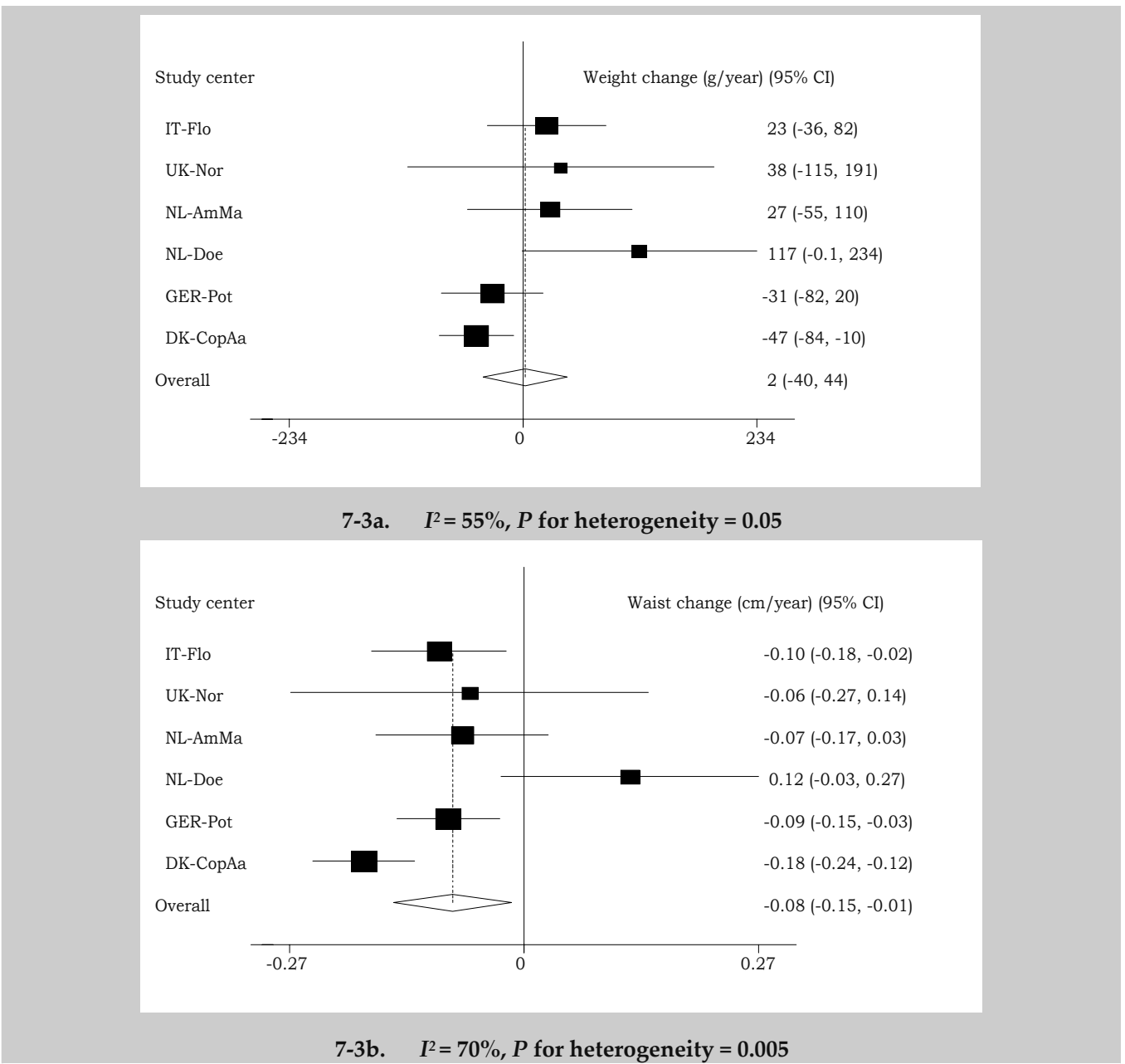

* Values presented are regression coefficients $(95 \% \mathrm{CI})$ for a $10 \mathrm{~g} /$ day of fruit and vegetable fiber intake with weight (7-3a) and waist circumference (7-3b) change.

Analyses were adjusted for baseline age, weight and height, gender, smoking, education, physical activity, follow-up duration, alcohol consumption, the intake of fat, carbohydrates, protein, glycemic index, cereal fiber, fiber from other sources and, for women, menopausal status and use of hormone replacement therapy. For waist circumference change analyses, baseline waist circumference was also adjusted for.

Overall estimates were based on random effect models.

Figure 7-3. Associations of fruit and vegetable fiber intake with changes in weight and waist circumference*.

After adjusting for fruit and vegetable fiber and fiber from other sources in addition to the other confounding factors, cereal fiber intake was inversely 
associated with weight and waist circumference change except in IT-Flo. On average, a $10 \mathrm{~g} /$ day cereal fiber was associated with an annual weight change of $-77 \mathrm{~g} / \mathrm{year}$ [95\% CI: -127, -26] $\left(I^{2}=38 \%, P\right.$ for heterogeneity $\left.=0.01\right)$ (Figure 7-2a) and an annual waist circumference of $-0.10 \mathrm{~cm} /$ year [95\% CI: $-0.18,-0.02$ ] $\left(I^{2}=80 \%\right.$, $P$ for heterogeneity <0.001) (Figure 7-2b).

Fruit and vegetable fiber intake was positively associated with weight change in four study centers, and inversely associated with waist change in five centers. The pooled estimate of association between $10 \mathrm{~g} /$ day of fruit and vegetable fiber and weight change was $2 \mathrm{~g} /$ year [95\% CI: $-40,44]\left(I^{2}=55 \%, P\right.$ for heterogeneity $\left.=0.05\right)$ (Figure 7-3a) and for waist circumference change $-0.08 \mathrm{~cm} /$ year [95\% CI: -0.15, -0.01] $\left(I^{2}=70 \%, P\right.$ for heterogeneity $\left.=0.005\right)$ (Figure $\left.7-3 \mathbf{b}\right)$.

Sensitivity analyses, including use of un-calibrated dietary variables, use of anthropometric data corrected for clothing and self-report, and exclusion of participants with incident cancer, type 2 diabetes or CVD during follow-up, did not essentially alter the results. Fiber from potatoes, nuts and legumes were not significantly associated with subsequent changes of weight or waist circumference. Including potato fiber into the fruit and vegetable fiber did not essentially change the results (data not shown).

\section{Discussion}

In this prospective cohort study, we observed an inverse association of total dietary fiber and cereal fiber intake with subsequent weight and waist circumference change. The intake of fruit and vegetable fiber was not appreciably associated with weight change, but had a similar inverse association with waist circumference change as compared to total dietary fiber and cereal fiber.

The main strengths of the current study are the large sample size and the large variation of fiber intake among participants from five different European countries. Utmost care has been made to standardize the measurements across all EPIC centers, for example by using calibrated dietary variables based on 24-hour dietary recall data collected using a uniform system, the related standardized nutrient database, and the standardized potential confounding variables such as education level and physical activity. A limitation of the study is the difference in methodologies used to collect anthropometric data at follow-up, as weight and waist circumference measurements at follow-up were self-reported instead of measured in four out of six study centers. We tried to overcome this by correcting for clothing differences and self-report using previously developed methods in the EPIC study. ${ }^{19}$ However, the results remained unchanged. We therefore used the uncorrected data and took the methodological differences into account by using random effect meta-analyses. Dietary information was collected only once at baseline, which excluded the possibility to investigate the concurrent association between changes in fiber intake and changes in weight and waist circumference. 
Findings from several observational and intervention studies support a beneficial role of total dietary fiber intake on maintaining a healthy body weight, ${ }^{20}$ promoting weight loss, ${ }^{2,21}$ and preventing weight gain..$^{3,4}$ Postulated physiological mechanisms by which dietary fiber helps in weight and waist circumference management have been summarized by Pereira and Ludwig previously. ${ }^{1}$ In brief, high fiber diets are more satiating, could lead to a reduced energy intake; fiber could limit the access of other nutrients to digestive enzymes; increasing fiber intake could improve insulin sensitivity and stimulate fat oxidation. All these aspects benefit weight control. Our finding on the protective role of higher total and cereal fiber intake in preventing long-term weight and waist circumference gain was in line with these previous findings, $, 3,4$ although randomized controlled trials on weight loss so far yield less consistent results. ${ }^{22}$ Although we observed a small effect when judged on the individual level, the effect of fiber on weight change observed in our study may be of public health relevance. A weight change of $39 \mathrm{~g} /$ year (for $10 \mathrm{~g} /$ day of fiber intake) represents approximately $34 \%$ of the mean weight change in this study population (115 g/year). Assuming the average absolute real annual weight gain is $400 \mathrm{~g}$ ( $\approx$ the mean in UK-Nor and NL-Doe), $10 \mathrm{~g}$ /day higher total dietary fiber intake would prevent about $10 \%$ of weight gain. As the daily fiber intake was only about $23 \mathrm{~g} / \mathrm{day}$ among participants of the current study, a $10 \mathrm{~g} /$ day increment would increase the average intake close to the recommended level of $35 \mathrm{~g} /$ day.

We observed moderate to large amount of heterogeneity across study centers and the reason for this is not completely known. Changes in weight and waist circumference were measured differently in some study centers. However, using available methods correcting these differences did not eliminate or reduce the heterogeneity. Despite the study is population-based in general, sources of study populations were slightly different between study centers. ${ }^{8}$ In general, we have no reasons to assume a priori that the relation between fiber intake and weight and waist circumference gain should be substantially different in the populations. However, subtle differences in misreporting of dietary intake and health consciousness among cohorts may exist. We therefore applied the current metaanalytical approach to analyze the associations first in each study center and then to obtain the pooled estimates using random effect models. The pooled estimates across study center represent the average level of effects.

Distinguishing the effects of fiber from different sources on weight and waist circumference gain is potentially important for formulating public health guidelines. At present, the benefits of increased fiber intake in the prevention and treatment of obesity and associate diseases such as CVD and type 2 diabetes mainly focuses on soluble fiber, coming mainly from fruits and vegetables. That is because the high viscosity of soluble fiber could facilitate the slowing down of gastric empty and the absorption of macronutrients.7, ${ }^{23}$ However, epidemiological studies in contrast show that cereal fiber, principally insoluble fiber, appear to offer protection from CVD and diabetes.5, 6, 24 Only one prospective cohort study has previously compared the effects 
of cereal fiber, fruit fiber and vegetable fiber on subsequent weight change. ${ }^{7}$ Among 27,082 male US health professionals aged 40-75 years, significant inverse associations of weight change with concurrent change in intake of total dietary fiber, cereal fiber, and fruit fiber, but not for vegetable fiber, were observed. ${ }^{7}$ This agrees with our findings on total and cereal fiber. However, the fruit and vegetable fiber in our study was not significantly associated with weight change. We combined the fiber from fruits and vegetables (not potatoes) because their associations with weight and waist circumference change were similar. This seems in conflict with the findings from an earlier analysis of the same data ${ }^{25}$ and other previous studies ${ }^{26,27}$ showing a benefits of fruit and vegetable intake in body weight control. However, our findings do not exclude the possibility that fruits and vegetables protect against weight gain through other nutrients, such as reduced energy density of the diet, a decreased dietary GI, reduced total fat intake, or all these non-fiber aspects combined.

We found a more pronounced protective effect of cereal fiber, which is mainly insoluble, on weight gain as compared to fruit and vegetable fiber, which is more soluble. Several explanations could be responsible for this finding. First, it could be due to misreporting. Fruits and vegetables are considered as healthy, therefore are prone to being over reported by study participants, especially among those who had lower intake or who were obese. Because misreporting may be more weight-related than waist circumference-related, ${ }^{28}$ the association of fruit and vegetable consumption with weight change is more likely to be biased than the association with waist circumference change. Secondly, cereal fiber is likely to be a marker of whole-grain foods, ${ }^{6}$ which have been shown to be associated with a lower BMI and central obesity in a meta-analysis including 15 cross-sectional or cohort studies. ${ }^{29}$ As compared to fruits and vegetables, whole grains contain more resistant starch, phytoestrogens and antioxidants including vitamins and trace minerals, such as calcium, potassium and magnesium, which all may have an effect on body weight.6, 29, 30 Furthermore, the main components of cereal fiber are cellulose and hemicellulose, which may have distinct effects on weight regulation. For example, in a randomized trial comparing the effects of pectin, cellulose and lignin on stool characteristics, only cellulose significantly decreased mean stool transit time and increased mean wet stool weight. ${ }^{31}$ The role of fiber fermentation, especially of soluble fiber, and its products short chain fatty acids (SCFA) in body weight regulation also deserves consideration and further exploration. SCFA could stimulate satiety and improve insulin sensitivity, thus exert a beneficial role on body weight regulation. ${ }^{1}$ On the other hand, part of the SCFA could be absorbed into the bloodstream and used as an energy source..$^{32}$

Overall, we found a small but statistically significant inverse association of total and cereal fiber with changes in both weight and waist circumference and of fruit and vegetable fiber with changes in waist circumference, but not weight. These findings may support that a higher intake of fiber, especially of cereal fiber, is beneficial for preventing (abdominal) obesity. 


\section{References}

1. Pereira MA, Ludwig DS. Dietary fiber and body-weight regulation. Observations and mechanisms. Pediatr Clin North Am. 2001;48(4):969-980.

2. Birketvedt GS, Aaseth J, Florholmen JR, et al. Long-term effect of fibre supplement and reduced energy intake on body weight and blood lipids in overweight subjects. Acta Medica (Hradec Kralove). 2000;43(4):129-132.

3. Liu S, Willett WC, Manson JE, et al. Relation between changes in intakes of dietary fiber and grain products and changes in weight and development of obesity among middle-aged women. Am J Clin Nutr. 2003;78(5):920-927.

4. Ludwig DS, Pereira MA, Kroenke $\mathrm{CH}$, et al. Dietary fiber, weight gain, and cardiovascular disease risk factors in young adults. Jama. 1999;282(16):1539-1546.

5. Rimm EB, Ascherio A, Giovannucci E, et al. Vegetable, fruit, and cereal fiber intake and risk of coronary heart disease among men. Jama. 1996;275(6):447-451.

6. Schulze MB, Schulz M, Heidemann C, et al. Fiber and magnesium intake and incidence of type 2 diabetes: a prospective study and meta-analysis. Archives of internal medicine. 2007;167(9):956-965.

7. Koh-Banerjee P, Franz M, Sampson L, et al. Changes in whole-grain, bran, and cereal fiber consumption in relation to 8-y weight gain among men. Am J Clin Nutr. 2004;80(5):1237-1245.

8. Du H, van der A DL, Ginder V, et al. Dietary energy density in relation to subsequent changes of weight and waist circumference in European men and women. Plos ONE. 2009;4(4):e5339.

9. Deharveng G, Charrondiere UR, Slimani N, et al. Comparison of nutrients in the food composition tables available in the nine European countries participating in EPIC. European Prospective Investigation into Cancer and Nutrition. Eur J Clin Nutr. 1999;53(1):60-79.

10. Mann J, Cummings JH, Englyst HN, et al. FAO/WHO scientific update on carbohydrates in human nutrition: conclusions. Eur J Clin Nutr. 2007;61 Suppl 1:S132-137.

11. Kaaks R, Slimani N, Riboli E. Pilot phase studies on the accuracy of dietary intake measurements in the EPIC project: overall evaluation of results. European Prospective Investigation into Cancer and Nutrition. Int J Epidemiol. 1997;26 Suppl 1:S26-36.

12. Bingham SA, Gill C, Welch A, et al. Validation of dietary assessment methods in the UK arm of EPIC using weighed records, and 24-hour urinary nitrogen and potassium and serum vitamin $C$ and carotenoids as biomarkers. Int J Epidemiol. 1997;26 Suppl 1:S137-151.

13. Tjonneland A, Overvad $K$, Haraldsdottir J, et al. Validation of a semiquantitative food frequency questionnaire developed in Denmark. Int J Epidemiol. 1991;20(4):906-912.

14. van Bakel MM, Slimani N, Feskens EJ, et al. Methodological challenges in the application of the glycemic index in epidemiological studies using data from the European Prospective Investigation into Cancer and Nutrition. J Nutr. 2009;139(3):568-575.

15. Ferrari P, Day NE, Boshuizen HC, et al. The evaluation of the diet/disease relation in the EPIC study: considerations for the calibration and the disease models. Int J Epidemiol. 2008;37(2):368-378.

16. Bes-Rastrollo M, van Dam RM, Martinez-Gonzalez MA, et al. Prospective study of dietary energy density and weight gain in women. Am J Clin Nutr. 2008;88(3):769-777.

17. Rinaldi S, Key TJ, Peeters PH, et al. Anthropometric measures, endogenous sex steroids and breast cancer risk in postmenopausal women: a study within the EPIC cohort. Int $J$ Cancer. 2006;118(11):2832-2839.

18. Smith-Warner SA, Spiegelman D, Ritz J, et al. Methods for pooling results of epidemiologic studies: the Pooling Project of Prospective Studies of Diet and Cancer. Am J Epidemiol. 2006;163(11):1053-1064.

19. Haftenberger M, Lahmann PH, Panico S, et al. Overweight, obesity and fat distribution in 50- to 64year-old participants in the European Prospective Investigation into Cancer and Nutrition (EPIC). Public Health Nutr. 2002;5(6B):1147-1162.

20. Newby PK, Maras J, Bakun P, et al. Intake of whole grains, refined grains, and cereal fiber measured with 7-d diet records and associations with risk factors for chronic disease. Am J Clin Nutr. 2007;86(6):1745-1753. 
21. Pasman WJ, Westerterp-Plantenga MS, Saris WH. The effectiveness of long-term supplementation of carbohydrate, chromium, fibre and caffeine on weight maintenance. Int J Obes Relat Metab Disord. 1997;21(12):1143-1151.

22. van Dam RM, Seidell JC. Carbohydrate intake and obesity. Eur J Clin Nutr. 2007;61 Suppl 1:S75-99.

23. Weickert MO, Mohlig M, Schofl C, et al. Cereal fiber improves whole-body insulin sensitivity in overweight and obese women. Diabetes Care. 2006;29(4):775-780.

24. Mozaffarian D, Kumanyika SK, Lemaitre RN, et al. Cereal, Fruit, and Vegetable Fiber Intake and the Risk of Cardiovascular Disease in Elderly Individuals. JAMA. 2003;289(13):1659-1666.

25. Buijsse B, Feskens EJ, Schulze MB, et al. Fruit and vegetable intakes and subsequent changes in body weight in European populations: results from the project on Diet, Obesity, and Genes (DiOGenes). Am J Clin Nutr. 2009;90(1):202-209.

26. Sartorelli DS, Franco LJ, Cardoso MA. High intake of fruits and vegetables predicts weight loss in Brazilian overweight adults. Nutrition research (New York, N.Y. 2008;28(4):233-238.

27. Vioque J, Weinbrenner $\mathrm{T}$, Castello $\mathrm{A}$, et al. Intake of fruits and vegetables in relation to 10-year weight gain among Spanish adults. Obesity (Silver Spring). 2008;16(3):664-670.

28. Mattisson I, Wirfalt E, Aronsson CA, et al. Misreporting of energy: prevalence, characteristics of misreporters and influence on observed risk estimates in the Malmo Diet and Cancer cohort. $\mathrm{Br} \mathrm{J}$ Nutr. 2005;94(5):832-842.

29. Harland JI, Garton LE. Whole-grain intake as a marker of healthy body weight and adiposity. Public Health Nutr. 2008;11(6):554-563.

30. Bhathena SJ, Velasquez MT. Beneficial role of dietary phytoestrogens in obesity and diabetes. Am J Clin Nutr. 2002;76(6):1191-1201.

31. Hillman L, Peters $\mathrm{S}$, Fisher A, et al. Differing effects of pectin, cellulose and lignin on stool $\mathrm{pH}$, transit time and weight. Br J Nutr. 1983;50(2):189-195.

32. Livesey G. The energy values of dietary fibre and sugar alcohols for man. Nutrition research reviews. 1992;5(1):61-84. 
Chapter 7

S-Table 7-1. Relative contribution of food groups to intake of cereal fiber and fruit \& vegetable fiber*.

\begin{tabular}{|l|c|c|c|c|c|c|}
\hline Food groups & IT-Flo & UK-Nor & NL-AmMa & NL-Doe & GER-Pot & DK-CopAa \\
\hline Men & & & Cereal fiber & & & \\
\hline Flour and starches & - & $0.2 \%$ & - & - & $0.1 \%$ & $1.6 \%$ \\
\hline Pasta, rice, and other grains & $28.5 \%$ & $7.8 \%$ & $5.9 \%$ & $5.0 \%$ & $2.5 \%$ & $2.6 \%$ \\
\hline Breads & $67.7 \%$ & $60.2 \%$ & $86.6 \%$ & $87.8 \%$ & $95.6 \%$ & $86.5 \%$ \\
\hline Breakfast cereals & - & $24.7 \%$ & $2.6 \%$ & $2.5 \%$ & $0.6 \%$ & $8.6 \%$ \\
\hline Biscuits and cracker & $0.4 \%$ & $6.6 \%$ & $3.4 \%$ & $3.5 \%$ & $0.6 \%$ & $0.7 \%$ \\
\hline Dough and pastry & $3.5 \%$ & $0.3 \%$ & $1.5 \%$ & $1.2 \%$ & $0.6 \%$ & - \\
\hline
\end{tabular}

\begin{tabular}{|c|c|c|c|c|c|c|}
\hline Dough and pastry & $3.5 \%$ & $0.3 \%$ & $1.5 \%$ & $1.2 \%$ & $0.6 \%$ & - \\
\hline \multicolumn{7}{|c|}{ Fruit and vegetable fiber } \\
\hline Leafy vegetables & $7.1 \%$ & $1.3 \%$ & $10.9 \%$ & $12.3 \%$ & $3.0 \%$ & $0.8 \%$ \\
\hline Fruiting vegetables & $14.0 \%$ & $7.4 \%$ & $16.5 \%$ & $14.5 \%$ & $16.2 \%$ & $9.2 \%$ \\
\hline Root vegetables & $4.2 \%$ & $12.0 \%$ & $7.2 \%$ & $8.2 \%$ & $7.3 \%$ & $7.0 \%$ \\
\hline Cabbages & $1.3 \%$ & $15.6 \%$ & $9.8 \%$ & $8.8 \%$ & $9.8 \%$ & $6.9 \%$ \\
\hline Mushrooms & $1.3 \%$ & $2.0 \%$ & $1.3 \%$ & $0.8 \%$ & $1.6 \%$ & $5.8 \%$ \\
\hline Grain and pod vegetables & $6.5 \%$ & $18.4 \%$ & $5.8 \%$ & $6.1 \%$ & $5.1 \%$ & $3.6 \%$ \\
\hline Onion and garlic & $1.4 \%$ & $5.3 \%$ & $1.1 \%$ & $0.8 \%$ & $1.5 \%$ & $8.8 \%$ \\
\hline Stalk vegetables, sprouts & $2.7 \%$ & $3.0 \%$ & $4.2 \%$ & $3.2 \%$ & $2.2 \%$ & $3.1 \%$ \\
\hline Salad and mixed vegetables & $1.0 \%$ & - & - & - & $4.9 \%$ & $13.2 \%$ \\
\hline Fruits & $57.2 \%$ & $33.4 \%$ & $43.2 \%$ & $45.4 \%$ & $47.1 \%$ & $41.5 \%$ \\
\hline Mixed fruits & $3.3 \%$ & $1.6 \%$ & - & - & $1.4 \%$ & - \\
\hline Olives & - & - & $0.1 \%$ & $0.05 \%$ & - & - \\
\hline Women & & & Cereal fib & & & \\
\hline Flour and starches & - & $0.2 \%$ & - & - & $0.1 \%$ & $1.6 \%$ \\
\hline Pasta, rice, and other grains & $20.9 \%$ & $9.3 \%$ & $6.0 \%$ & $5.1 \%$ & $2.9 \%$ & $2.3 \%$ \\
\hline Breads & $73.7 \%$ & $58.3 \%$ & $84.5 \%$ & $86.1 \%$ & $94.7 \%$ & $86.3 \%$ \\
\hline Breakfast cereals & - & $26.9 \%$ & $3.4 \%$ & $2.9 \%$ & $1.0 \%$ & $9.1 \%$ \\
\hline Biscuits and cracker & $0.7 \%$ & $4.8 \%$ & $4.4 \%$ & $4.6 \%$ & $0.6 \%$ & $0.7 \%$ \\
\hline Dough and pastry & $4.6 \%$ & $0.4 \%$ & $1.8 \%$ & $1.3 \%$ & $0.6 \%$ & - \\
\hline
\end{tabular}

\begin{tabular}{|c|c|c|c|c|c|}
\hline Dough and pastry & $4.6 \%$ & $0.4 \%$ & $1.8 \%$ & $1.3 \%$ & $0.6 \%$ \\
\hline
\end{tabular}

\begin{tabular}{|c|c|c|c|c|c|c|}
\hline Leafy vegetables & $6.8 \%$ & $1.5 \%$ & $10.1 \%$ & $11.6 \%$ & $3.3 \%$ & $0.5 \%$ \\
\hline Fruiting vegetables & $14.4 \%$ & $7.4 \%$ & $15.6 \%$ & $13.2 \%$ & $16.1 \%$ & $8.4 \%$ \\
\hline Root vegetables & $4.7 \%$ & $11.6 \%$ & $7.4 \%$ & $8.1 \%$ & $7.5 \%$ & $9.5 \%$ \\
\hline Cabbages & $1.4 \%$ & $15.2 \%$ & $9.5 \%$ & $8.5 \%$ & $8.8 \%$ & $5.8 \%$ \\
\hline Mushrooms & $1.1 \%$ & $1.9 \%$ & $1.2 \%$ & $0.8 \%$ & $1.3 \%$ & $3.8 \%$ \\
\hline Grain and pod vegetables & $6.0 \%$ & $15.2 \%$ & $4.2 \%$ & $4.3 \%$ & $3.7 \%$ & $2.9 \%$ \\
\hline Onion and garlic & $1.4 \%$ & $5.1 \%$ & $1.1 \%$ & $0.8 \%$ & $1.0 \%$ & $7.0 \%$ \\
\hline Stalk vegetables, sprouts & $3.2 \%$ & $3.2 \%$ & $4.5 \%$ & $3.5 \%$ & $2.1 \%$ & $2.3 \%$ \\
\hline Salad and mixed vegetables & $0.7 \%$ & - & - & - & $4.1 \%$ & $12.4 \%$ \\
\hline Fruits & $57.4 \%$ & $37.7 \%$ & $46.5 \%$ & $49.1 \%$ & $51.1 \%$ & $47.5 \%$ \\
\hline Mixed fruits & $2.8 \%$ & $1.1 \%$ & - & - & $0.9 \%$ & - \\
\hline Olives & - & - & $0.1 \%$ & $0.04 \%$ & - & - \\
\hline
\end{tabular}

* Sums may not be $100 \%$ due to rounding errors. Missing means those food groups were not asked in those countries. 


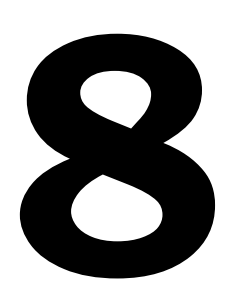

\title{
Genetic polymorphisms in the hypothalamic pathway in relation to subsequent changes of weight and waist circumference
}

\author{
H. Du on behalf of the DiOGenes Project* \\ In preparation
}

\begin{abstract}
Background: Regulation of energy intake plays a critical role in obesity development. However, little is known about whether single nucleotide polymorphisms (SNPs) in this pathway are associated with weight and waist change, and whether dietary factors could modify their impacts.

Objective: To investigate the associations of SNPs in or near 15 candidate genes involved in the hypothalamus pathway with subsequent changes in weight and waist circumference, and to explore potential interactions of these SNPs with the dietary glycemic index (GI).

Design: Case-cohort study with participants from five European countries.

Methods: Cases $(n=6,000)$ were selected from the total eligible cohort $(n=50,293)$ as those with the greatest unexplained annual weight gain during follow-up. A random sample $(n=7,061)$ was drawn with the intention to obtain an equal number of cases and non cases. Using the Illumina ${ }^{\circledR}$ platform, 134 SNPs were genotyped to capture the complete genetic variation across candidate genes, of which 123 were successfully genotyped. Logistic regression analyses were conducted to determine the additive effects of the minor alleles of each SNP on the case-non case status. Among the random sample, linear regression analyses were performed to evaluate the associations between the minor alleles and changes in weight (g/year) and waist circumference ( $\mathrm{cm} /$ year) assuming additive genetic models. Interactions between SNPs and dietary GI were tested by including the cross product terms in the regression models. The false discovery rate method was used to adjust for multiple testing.

Results: None of the SNPs under investigation showed a significant main effect on weight or waist change after correction for multiple comparisons. However, in the linear regression analyses, for both weight and waist change the rs7180849 SNP, a
\end{abstract}


variant near the neuromedin $\beta$ gene, showed a significant interaction with dietary GI $\left(P=3 \times 10^{-5}\right.$ and $5 \times 10^{-5}, Q=0.004$ and 0.006 respectively).

Conclusion: None of the SNPs in or near the 15 candidate genes involved in the hypothalamic regulation of energy intake had a direct association with weight and waist change. Individuals carrying the minor allele of the rs7180849 SNP seemed to have gained more weight and waist circumference when consuming a high GI diet than non-carriers. When confirmed, following a low GI diet might be particularly important for these people to prevent (abdominal) obesity.

* Co-authors in alphabetic order:

D. L. van der A (National Institute for Public Health and the Environment (RIVM), The Netherlands)

L. Ängquist (Institute of Preventive Medicine, Copenhagen University Hospital, Centre for Health and Society, Denmark)

H. Boeing (Department of Epidemiology, German Institute of Human Nutrition, Germany)

E.J.M. Feskens (Division of Human Nutrition, Wageningen University, The Netherlands)

C. Holst (Institute of Preventive Medicine, Copenhagen University Hospital, Centre for Health and Society, Denmark)

R.J.F. Loos (MRC Epidemiology Unit, Institute of Medical Science, UK)

K. Overvad (Department of Cardiology and Clinical Epidemiology, Aarhus University Hospital, Denmark)

D. Palli (Molecular and Nutritional Epidemiology Unit, Cancer Research and Prevention Institute (ISPO), Italy)

V. Santhanakrishnan (MRC Epidemiology Unit, Institute of Medical Science, UK)

W. H.M. Saris (Department of Human Biology, Nutrition and Toxicology Research Institute of Maastricht (NUTRIM), The Netherlands)

T. I. A. Sørensen (Institute of Preventive Medicine, Copenhagen University Hospital, Centre for Health and Society, Denmark)

A. Tjønneland (Danish Cancer Society, Institute of Cancer Epidemiology, Copenhagen, Denmark)

N. Wareham (MRC Epidemiology Unit, Institute of Medical Science, UK) 


\section{Introduction}

The prevalence of obesity is rising worldwide. This epidemic is likely to be a consequence of modernization, which yields palatable and easily available highcaloric foods and promotes a sedentary lifestyle. During the past decades, a myriad of dietary factors have been investigated for their potential association with weight change or obesity, such as dietary glycemic index (GI), which is an indicator classifying carbohydrate containing foods based on the blood glucose response after consumption. ${ }^{1}$ Although not completely consistent, findings from clinical intervention studies and epidemiological studies in general suggest that diets low in GI are beneficial in obesity prevention and weight control.1-4 One of the most plausible mechanisms seems to be that low GI diets could enhance satiation and satiety, leading to a decreased energy intake, thus prevent weight gain and promote weight loss. ${ }^{4,5}$ Consistent with this, previous work within the DiOGenes study has shown that a higher dietary GI is associated with greater enlargement in waist circumference. ${ }^{6}$

Dietary factors, however, can not fully explain the susceptibility to obesity. Evidence from family, twin and adoption studies has indicated a heritable component of obesity ranging from $40 \%$ to $70 \% .^{7}$ The 2005 update of the human obesity gene map has revealed 127 genes associated with human obesity. ${ }^{8,9}$ Some of these obesity genes are involved in the hypothalamic signaling network, consist of gastrointestinal, adiposity, and hypothalamic signals, which plays a critical role in the regulation of food intake. ${ }^{8-10}$ For example, many studies have reported an association of common variants in the leptin and leptin receptor gene with BMI or obesity status. ${ }^{9}$ In a large group of Caucasian families, common polymorphisms within the ghrelin receptor gene region have been associated with obesity and this finding has been replicated in a general population. ${ }^{11}$ A number of studies, including a recent genome-wide association study, have associated melanocortin- 4 receptor (MC4R) gene variants with obesity ${ }^{9} 12$ In contrast to the large number of studies investigating the genetic influence of BMI or obesity status, few attempts have been made at identifying genetic variants for changes of weight and waist circumference in adults. 9,13

The aim of the current case-cohort study was to investigate whether SNPs within or near genes involved in food intake regulation are associated with subsequent weight and waist gain and to examine their potential interaction with dietary GI. The results will be of relevance for both understanding the etiology of weight (waist) gain and tailoring dietary prevention interventions on obesity.

\section{Methods}

Participants

Participants came from eight cities or counties within five European countries participating in the European Prospective Investigation into Cancer and Nutrition 
(EPIC) study, which are Florence (Italy), Norfolk (UK), Amsterdam, Maastricht and Doetinchem (The Netherlands), Potsdam (Germany), Copenhagen and Aarhus (Denmark). ${ }^{14}$ We selected those who were younger than 60 years at baseline and younger than 65 years at follow-up, who had a blood sample available and had baseline information on diet, weight and height, and follow-up information on weight, who had stable smoking habits, had no previous diagnosis of cancer, cardiovascular diseases (CVD), and diabetes at baseline and during follow-up, and had an annual weight change not higher than $5 \mathrm{~kg} /$ year. In total 50,293 men and women were included in the eligible cohort.

Cases were defined as those individuals who had experienced the greatest degree of unexplained weight gain. They were identified by using the residuals from a regression model of annual weight change on baseline values of age, weight and height, smoking status (current/former/never smokers), and follow-up time. Regression models were run separately for each country and were stratified for men and women. In each of the five countries except Italy, 600 male and 600 female cases were selected. The Italian cohort consisted of a general population-based sample and of women participating in a population-based breast cancer screening program. Thus, male participants were underrepresented $(27 \%)$. To follow the same gender distribution as in the original cohort, 300 male and 900 female cases were selected for the present study. The sub-cohort sample comprised a random sample of the total eligible cohort which was drawn in such a way that the total number of non cases in each center equaled the number of cases $(n=1,200)$. Therefore, in all centers except Denmark, where overlap between cases and sub-cohort was negligible $(n=79)$, over sampling of the random samples was performed. In total, 11,921 participants were included in the present genetic association study: 6,000 cases and a sub-cohort of 7,061 individuals including 5,921 non cases.

\section{Dietary, anthropometric, and other measurements}

Validated country-specific food frequency questionnaires (FFQs) were used to collect dietary information at baseline ${ }^{14}$ Energy and nutrient intake of FFQ data were calculated using country-specific food composition tables and subsequently calibrated using 24-hour recall data collected from a random sample of the total EPIC cohort using a software program specifically designed to standardize the dietary measurements across European populations..$^{15}$ Energy and nutrient intake from 24hour recalls were calculated based on the standardized European Nutrient DataBase. ${ }^{16}$ A specially developed GI database was used to calculate dietary GI and the methodologies of calculation have been described in detail elsewhere. ${ }^{17,18}$

Details of the anthropometric measurements have been described previously. ${ }^{6}$ In brief, at baseline all participants were measured for weight, height and waist circumference using standard study protocols. ${ }^{19}$ At follow-up, participants in Norfolk (UK) and Doetinchem (NL) were measured by trained technicians, while the remaining participants measured their weight and waist circumference at home 
according to the guidance provided. Due to these differences in methods used to collect anthropometric information at follow-up and the difference in length of follow-up, participants from Doetinchem (NL) were treated separately from the other Dutch participants in Amsterdam and Maastricht (NL). Participants from Copenhagen and Aarhus (DK) were combined because no such differences between these two groups existed. This resulted in six different study centers, namely Florence (IT-Flo), Norfolk (UK-Nor), Amsterdam-Maastricht (NL-AmMa), Doetinchem (NL-Doe), Potsdam (GER-Pot) and Copenhagen-Aarhus (DK-CopAa).

Information on lifestyle was collected via self-administered questionnaires at baseline. Questions covered age, gender, physical activity, education level, smoking, menopausal status, and use of hormone replace therapy (HRT). Physical activity level was indexed into five categories (inactive, moderately inactive, moderately active, active, or unknown) based on occupational and recreational activities. ${ }^{14}$ Education level was inquired as the highest level of school achieved and participants were classified into either primary school and less, technical-professional school, secondary school, university degree, or unknown. Smoking information was also available at follow-up. Information on health status (cancer, CVD, and diabetes) was collected using either questionnaires or disease registries.

\section{Selection of candidate genes and SNPs}

We selected 15 candidate genes encoding signals involved in the function of the hypothalamic signaling network, including the genes for cholecystokinin (CCK), CCK receptor, leptin, leptin receptor, ghrelin, glucagon-like peptide-1 (GLP-1), peptide YY3-36 (PYY), MC4R, interleukin-6 (IL-6), neuropeptide Y (NPY), proopiomelanocortin (POMC), nucleobindin 2 (NUCB2), mammalian target of rapamycin (mTOR), neuromedin $\beta$ (NMB), and serotonin receptor. CCK, PYY, and GLP-1 are known as satiety hormones. They are released from the gastrointestinal tract and can reduce appetite and food intake. Ghrelin, on the other hand, is a hunger hormone that could increase food intake. ${ }^{20}$ Leptin is the major adiposity signal that monitors nutritional status and prevents excess weight gain..$^{21}$ IL-6 may have a similar function as leptin. ${ }^{22}$ NPY, NUCB2 and POMC are hypothalamic signals with either orexigenic (NPY) ${ }^{23}$ or anorexigenic (NUCB2 and POMC) $)^{24,25}$ effect. mTOR is an important mediator between the adiposity signals and hypothalamic peptides. ${ }^{10} \mathrm{NMB}$ is a member of the bombesin-like peptides family and has been associated with eating behavior and adiposity changes. ${ }^{26,}{ }^{27}$ Serotonin could suppress food intake and may mediate the anorexigenic effects of leptin..$^{28}$

Based on the International HapMap data for the European ancestry (CEU), we selected SNPs to ensure full coverage of the complete common genetic variations in the candidate genes (including $5 \mathrm{~kb}$ upstream and downstream of the gene). For those SNPs in complete linkage disequilibrium (LD) i.e. where the linkage measures $\mathrm{D}^{\prime}=1$ and $\mathrm{r}^{2}=1$, only one SNP was genotyped. In total, 134 SNPs were selected. A 
complete list of the selected SNPs, including the candidate genes, is shown in a supplementary table (S-Table 8-1).

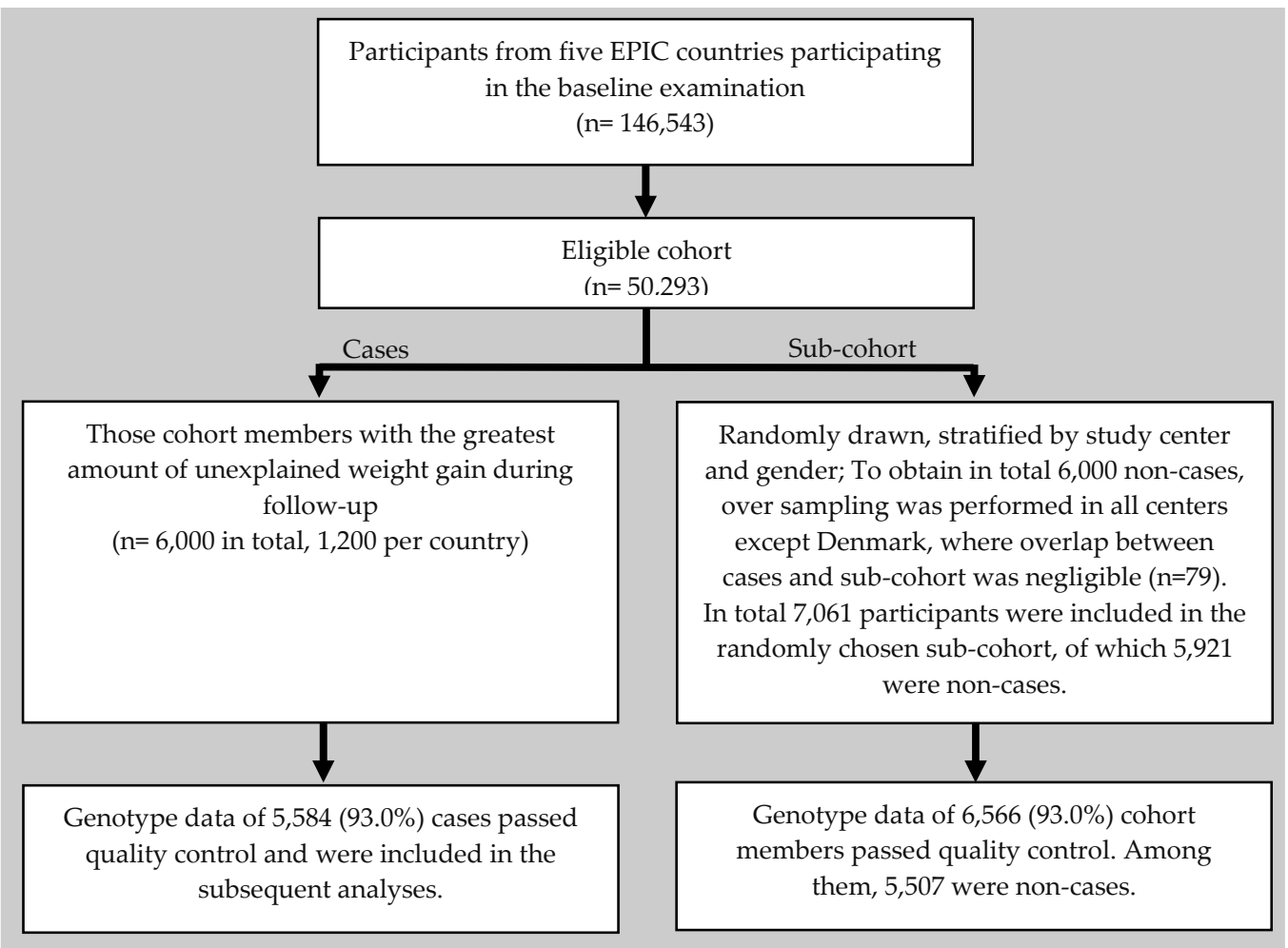

Figure 8-1. Flow diagram of participant selection.

\section{DNA extraction and genotyping}

For all participants except those from the UK, genomic DNA was extracted from the buffy coats with a salting out method. ${ }^{29}$ For participants from the UK, wholegenome amplified DNA was used. Genomic and amplified DNA samples were quality-checked, quantified and normalized to approximately $100 \mathrm{ng} / \mathrm{ml}$ and $2.0 \mu \mathrm{g}$ before genotyping. High throughput SNP genotyping was carried out using the Illumina ${ }^{\circledR}$ Beadstation Genotyping System at IntegraGen, France. Researchers and laboratory personnel were blinded to the case status and phenotypic data of the samples. The pre-defined criteria for successful genotyping were: the discordance rate between duplicates $\leq 3 \% ; \geq 90 \%$ of SNPs per sample should be genotyped and $\geq$ $95 \%$ of samples per SNP should be genotyped. To optimize the number of SNPs for subsequent data analyses, we applied these criteria within each country.

After merging the genotype and phenotype data in the Data Hub, genotype distributions were tested for accordance with Hardy-Weinberg equilibrium (HWE) in the randomly selected sub-cohort. Only those SNPs whose distributions did not 
significantly deviate from HWE $(P>0.01)$ were retained in the subsequent analyses. In total, 123 SNPs were successfully genotyped for 11,091 participants. The case group included 5,584 participants and the sub-cohort included 6,566 participants of whom 5,507 were non cases.

The flow chart of participant selection is shown in Figure 8-1.

\section{Statistical methods}

Power calculations were performed using QUANTO software, Version 1.2.4 (May 2009)..$^{30}$ The lowest detectable effects in case-non case analyses (odds ratio, OR) at $80 \%$ of power ranged from 1.4 for minor allele frequency (MAF) $5 \%$ to 1.09 for MAF 50\%. Except for the descriptive analyses, which were conducted using SAS 9.1 for Windows (SAS Institute, Cary, NC), all statistical analyses were conducted using STATA 9.2 for Windows (StataCorp LP, Texas, USA).

Data were analyzed using two statistical models, a logistic regression model to analyze the effect of each individual SNP on the risk of gaining a greater amount of weight during follow-up (case-non case analysis) and a generalized linear regression model to examine the effect of each SNP on subsequent changes of weight ( $\mathrm{g} /$ year) and waist circumference (cm/year) among participants included in the sub-cohort (sub-cohort analysis). An additive genetic model was assumed. The analyses of the SNP main effects were not adjusted. However, in the sub-cohort analysis, adjustment was made for those variables used to define the case status, namely baseline values of age, weight and height, gender, smoking status, and follow-up time, to reduce the variation.

For SNP-GI interaction analyses, besides SNP, GI, the cross product of SNP $\times$ GI were included in the models as independent variables, the logistic regression analyses were adjusted for physical activity, education level, alcohol intake, fat, protein, carbohydrates, fiber, and for women menopausal status and the use of hormone replace therapy. The linear regression analyses were additionally adjusted for the previously mentioned variables used for defining the case status. For waist change analyses, baseline waist circumference was also adjusted for.

All these analyses were first conducted separately for each study center and then random-effect meta-analyses were performed, in order to take into account the possible heterogeneity across study centers and to pool the estimates into an overall (weighted) estimate. The significance ( $P$ value) of heterogeneity was tested using the Cochran Q-test. ${ }^{31}$

Multiple comparisons were corrected for using the commonly used false discovery rate (FDR) method and FDR-adjusted $P$ values $(Q)<0.1$ were considered significant.

\section{Results}

Besides the significant difference in annual weight changes between cases and non cases (1,428 vs. $30 \mathrm{~g} /$ year) (Table 8-1), cases also included more overweight (43 
vs. 39\%) and obese (17 vs. 9\%) participants, had higher baseline values of body weight (76.3 vs. $72.6 \mathrm{~kg})$, BMI ( 26.4 vs. $\left.25.2 \mathrm{~kg} / \mathrm{m}^{2}\right)$, and waist circumference ( $87.5 \mathrm{vs.}$ $84.4 \mathrm{~cm}$ ), had higher BMI (29.4 vs. $\left.25.3 \mathrm{~kg} / \mathrm{m}^{2}\right)$ and waist circumference (98.5 vs. 88.4 $\mathrm{cm})$ at follow-up, and gained more annual waist circumference (1.66 vs. $0.51 \mathrm{~cm} /$ year) $(P<0.0001$ for all). Differences in GI and total energy intake were not significant. Although statistically significant, the differences in GL and dietary fiber were small in terms of average daily intake.

\begin{tabular}{|c|c|c|c|c|}
\hline \multicolumn{5}{|c|}{ Table 8-1. Characteristics of participants. } \\
\hline & $\begin{array}{c}\text { Cases } \\
(\mathrm{n}=5,584)\end{array}$ & $\begin{array}{l}\text { Non cases } \\
(\mathrm{n}=5,507)\end{array}$ & $P$ values* & $\begin{array}{l}\text { Sub-cohort } \\
(\mathrm{n}=6,566)\end{array}$ \\
\hline Age, yrs & $47.6 \pm 7.5$ & $48.0 \pm 7.3$ & 0.003 & $47.9 \pm 7.3$ \\
\hline Gender, \%men & 45 & 45 & matched & 46 \\
\hline Overweight, \% & 43 & 39 & $<0.0001$ & 39 \\
\hline Obesity, \% & 17 & 9 & $<0.0001$ & 10 \\
\hline Baseline weight, $\mathrm{kg}$ & $76.3 \pm 14.3$ & $72.6 \pm 13.4$ & $<0.0001$ & $73.2 \pm 13.6$ \\
\hline Baseline BMI, $\mathrm{kg} / \mathrm{m}^{2}$ & $26.4 \pm 4.2$ & $25.2 \pm 3.6$ & $<0.0001$ & $25.4 \pm 3.7$ \\
\hline Annual weight change, $g / y r$ & $1,428 \pm 684$ & $30 \pm 622$ & $<0.0001$ & $245 \pm 801$ \\
\hline BMI at follow-up, $\mathrm{kg} / \mathrm{m}^{2}$ & $29.4 \pm 4.4$ & $25.3 \pm 3.5$ & $<0.0001$ & $25.9 \pm 3.9$ \\
\hline Baseline waist circumference, $\mathrm{cm}$ & $87.5 \pm 12.7$ & $84.4 \pm 12.0$ & $<0.0001$ & $84.9 \pm 12.1$ \\
\hline Annual waist change, $\mathrm{cm} / \mathrm{yr}$ & $1.66 \pm 1.29$ & $0.51 \pm 1.13$ & $<0.0001$ & $0.67 \pm 1.18$ \\
\hline Waist circumference at follow-up, $\mathrm{cm}$ & $98.5 \pm 13.1$ & $88.4 \pm 11.7$ & $<0.0001$ & $89.9 \pm 12.4$ \\
\hline Follow-up time, yrs & $6.8 \pm 2.5$ & $6.8 \pm 2.5$ & 0.08 & $6.9 \pm 2.5$ \\
\hline Glycemic index $(\mathrm{GI})^{+}$ & $56.5 \pm 2.6$ & $56.5 \pm 2.5$ & 0.8 & $56.5 \pm 2.5$ \\
\hline 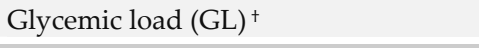 & $139.7 \pm 33.8$ & $141.1 \pm 32.3$ & 0.02 & $141.3 \pm 32.5$ \\
\hline Total energy intake ${ }^{\dagger}, k c a l / d a y$ & $2,263 \pm 522$ & $2,268 \pm 494$ & 0.6 & $2,271 \pm 501$ \\
\hline Dietary fiber ${ }^{\dagger}, g /$ day & $22.1 \pm 5.4$ & $22.5 \pm 5.7$ & 0.0004 & $22.4 \pm 5.7$ \\
\hline
\end{tabular}

\section{Case-non case analyses}

Among the 123 SNPs, two had significant $(P<0.05)$ direct associations with the risk of weight gain, which were $\mathrm{rs} 1859223$ in $P Y Y(\mathrm{OR}=0.91$ per copy of the minor allele, $P=0.009)$ and rs11571842 in CCK (OR $=1.06$ per copy of the minor allele, $P=$ 0.03) (Table 8-2). However, these associations were not statistically significant after adjustment for multiple testing $(Q>0.9)$.

Three SNPs showed a significant positive interaction with GI on weight gain risk, including rs7180849 near NMB $(P=0.003)$, rs2292462 in $N M B(P=0.007)$, and rs9311317 near CCK $(P=0.04)$. However, these associations attenuated to nonsignificant after correction for multiple testing $(Q>0.4)$.

\section{Sub-cohort analyses}




\section{Weight change}

Two SNPs were inversely associated with weight change, which were rs1058046 in PYY, $(\beta=-27 \mathrm{~g} /$ year $)$ and $\mathrm{rs10493380}$ in the leptin receptor gene (LEPR), $(\beta=-31$ $\mathrm{g} /$ year). One SNP, rs26802 in the ghrelin gene (GHRL), was positively associated with weight change ( $\beta=25 \mathrm{~g} /$ year) (Table 8-3). However, after adjustment for multiple testing, these effects were no longer statistically significant $(Q>0.9)$.

\begin{tabular}{|c|c|c|c|c|c|c|c|}
\hline SNP & $\begin{array}{l}\text { Nearest } \\
\text { gene }\end{array}$ & $\begin{array}{c}\text { No. of } \\
\text { participants }\end{array}$ & $\begin{array}{l}\text { Major allele / } \\
\text { Minor allele }\end{array}$ & MAF & $\begin{array}{c}\text { Odds ratio } \\
(95 \% \mathrm{CI})\end{array}$ & $\begin{array}{c}P \\
\text { value }\end{array}$ & $\begin{array}{c}\mathrm{Q} \\
\text { value }\end{array}$ \\
\hline \multicolumn{8}{|c|}{ Main effects } \\
\hline rs1859223 & PYY & 11,091 & $\mathrm{G} / \mathrm{C}$ & 0.16 & $0.91(0.85 ; 0.98)$ & 0.01 & $>0.9$ \\
\hline rs11571842 & CCK & 11,091 & G/A & 0.49 & $1.06(1.01 ; 1.12)$ & 0.03 & $>0.9$ \\
\hline \multicolumn{8}{|c|}{$\mathrm{SNP} \times \mathrm{GI}$ interaction $*$} \\
\hline rs7180849 & $N M B$ & 8,759 & $\mathrm{G} / \mathrm{A}$ & 0.17 & $1.10(1.03 ; 1.18)$ & 0.003 & 0.4 \\
\hline rs2292462 & $N M B$ & 11,091 & $\mathrm{~A} / \mathrm{C}$ & 0.47 & $1.05(1.01 ; 1.08)$ & 0.007 & 0.4 \\
\hline rs9311317 & CCK & 11,091 & A / G & 0.25 & $1.04(1.01 ; 1.08)$ & 0.04 & 0.9 \\
\hline
\end{tabular}

SNP: Single nucleotide polymorphism; GI: Glycemic index; MAF: Minor allele frequency; $95 \%$ CI: $95 \%$ confidence interval.

* The models included SNP, GI, SNP×GI, physical activity, education level, alcohol intake, energy-adjusted residuals of fat, protein, carbohydrates, and fiber, and for women, menopausal status and the use of hormone replace therapy.

\begin{tabular}{|c|c|c|c|c|c|c|c|}
\hline SNP & $\begin{array}{l}\text { Nearest } \\
\text { gene }\end{array}$ & $\begin{array}{c}\text { No. of } \\
\text { participants }\end{array}$ & $\begin{array}{l}\text { Major allele / } \\
\text { Minor allele }\end{array}$ & MAF & $\begin{array}{c}\beta \text { (g/year) } \\
(95 \% \mathrm{CI})\end{array}$ & $\begin{array}{c}P \\
\text { value }\end{array}$ & $\begin{array}{c}Q \\
\text { value }\end{array}$ \\
\hline \multicolumn{8}{|c|}{ Main effects* } \\
\hline rs1058046 & $P Y Y$ & 6,566 & G / C & 0.33 & $-27(-51 ;-3)$ & 0.03 & $>0.9$ \\
\hline rs10493380 & $L E P R$ & 6,566 & $\mathrm{~A} / \mathrm{C}$ & 0.19 & $-31(-60 ;-2)$ & 0.04 & $>0.9$ \\
\hline rs26802 & GHRL & 6,566 & $\mathrm{~A} / \mathrm{C}$ & 0.33 & $25(1-49)$ & 0.04 & $>0.9$ \\
\hline \multicolumn{8}{|c|}{$\mathrm{SNP} \times \mathrm{GI}$ interaction ${ }^{+}$} \\
\hline rs7180849 & $N M B$ & 3,723 & $\mathrm{G} / \mathrm{A}$ & 0.17 & $47(25 ; 69)$ & $3 \times 10^{-5}$ & 0.004 \\
\hline rs214075 & NUCB2 & 6,566 & $\mathrm{C} / \mathrm{A}$ & 0.41 & $16(0.9-30)$ & 0.04 & $>0.9$ \\
\hline rs6719226 & POMC & 6,566 & $\mathrm{G} / \mathrm{C}$ & 0.04 & $-40(-78 ;-1.8)$ & 0.04 & $>0.9$ \\
\hline rs1137101 & $L E P R$ & 1,313 & A / G & 0.46 & $-26(-52 ;-1.0)$ & 0.04 & $>0.9$ \\
\hline rs2292462 & $N M B$ & 6,566 & $\mathrm{~A} / \mathrm{C}$ & 0.47 & $16(0.5 ; 31)$ & 0.04 & $>0.9$ \\
\hline \multicolumn{8}{|c|}{$\begin{array}{l}\text { SNP: Single nucleotide polymorphism; GI: Glycemic index; MAF: Minor allele frequency; } \beta \text { : Regression } \\
\text { coefficient; } 95 \% \text { CI: } 95 \% \text { confidence interval. } \\
\text { * The models were adjusted for baseline age, weight, and height, gender, follow-up time, and smoking. } \\
\text { + The model additionally included SNP, GI, SNP×GI, physical activity, education level, alcohol intake, energy- } \\
\text { adjusted residuals of fat, protein, carbohydrates and fiber, and for women, menopausal status and the use of } \\
\text { hormone replace therapy. }\end{array}$} \\
\hline
\end{tabular}




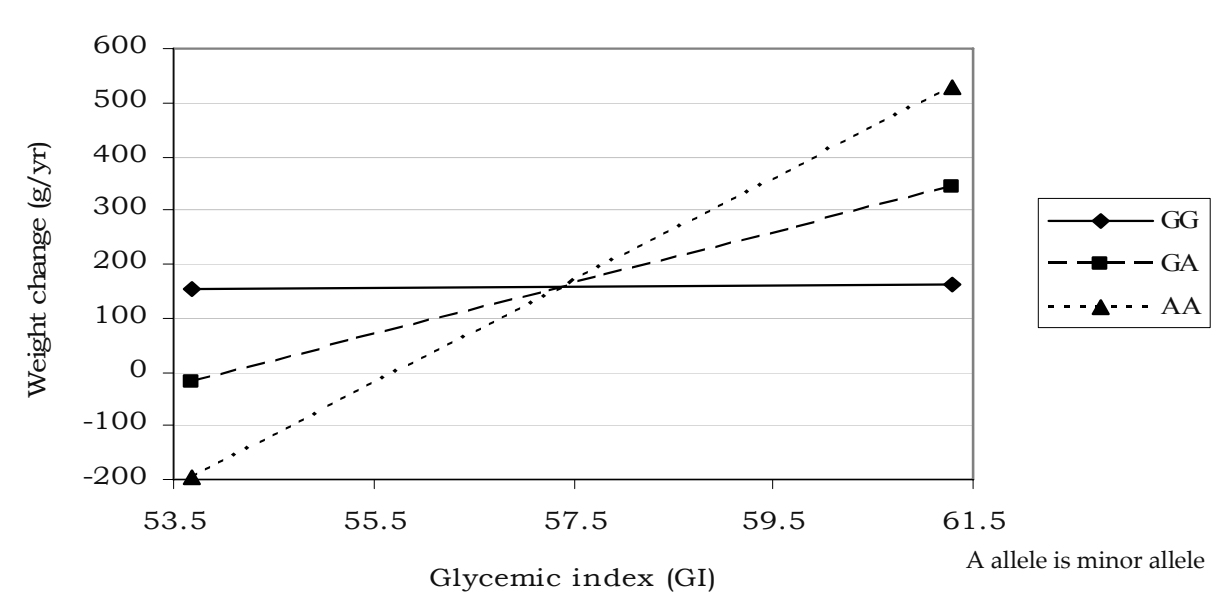

Figure 8-2. The regression of weight change on GI and by genotypes of the rs7180849 SNP.

Five SNPs showed a significant interaction with GI, including rs7180849 (near NMB; $P=3 \times 10^{-5}$ ), rs214075 (in NUCB2; $P=0.04$ ), rs2292462 (in NMB; $P=0.04$ ), rs6719226 (near POMC; $P=0.04$ ) and rs1137101 (in $L E P R ; P=0.04$ ). After adjustment for multiple testing, only the interaction between rs7180849 and GI remained significant $(Q=0.004)$. The association between $\mathrm{GI}$ and weight change by genotypes of rs7180849 is illustrated in Figure 8-2. As compared to major allele (G) carriers, minor allele (A) carriers appeared to be more sensitive to a difference in dietary GI. When GI increased from the lowest to the highest quintile, the annual weight change increased from -195 g/year to $526 \mathrm{~g} /$ year for the participants with the AA genotype and from $-20 \mathrm{~g} /$ year to $344 \mathrm{~g} /$ year for those with the GA genotype, while the annual weight change hardly changed for those with the GG genotype (154 g/year to 161 g/year).

\section{Waist change}

Eight SNPs were significantly, although weakly, associated with changes in waist circumference. These included rs1074078 (near $m$ TOR; $\beta=-0.05 \mathrm{~cm} /$ year and $P$ $=0.007$ ), $\mathrm{rs} 10766383$ (in NUCB2; $\beta=0.05 \mathrm{~cm} /$ year and $P=0.01$ ), rs10493380 (in LEPR; $\beta=-0.05 \mathrm{~cm} /$ year and $P=0.02$ ), rs7628795 (near $C C K ; \beta=-0.04 \mathrm{~cm} /$ year and $P=0.03$ ), rs11129949 (in CCK; $\beta=0.05 \mathrm{~cm} /$ year and $P=0.03$ ), rs10832763 (in NUCB2; $\beta=0.06$ $\mathrm{cm} /$ year and $P=0.03$ ), rs12145690 (near $L E P R ; \beta=0.03 \mathrm{~cm} /$ year and $P=0.04$ ), and rs12700386 (near $I L-6 ; \beta=0.04 \mathrm{~cm} /$ year and $P=0.04$ ). However, none of these associations remained significant after adjustment for multiple testing $(Q=0.7$ for all) (Table 8-4).

Three SNPs showed a significant interaction with GI: rs7180849 (near NMB; $P=$ $5 \times 10^{-5}$ ), rs2025805 (in $L E P R ; P=0.04$ ), and rs9436746 (in $L E P R ; P=0.04$ ). After adjustment for multiple testing, only the interaction between rs7180849 and GI 
remained significant $(Q=0.006)$. The association between $G I$ and waist change by genotypes of rs7180849 is illustrated in Figure 8-3. Minor allele (A) carriers were more sensitive to the GI difference as compared to major allele $(G)$ carriers. In other words, annual waist gain of participants carrying A allele was smaller at low level of dietary GI and larger at high level of dietary GI as compared to the waist gain in those carrying $\mathrm{G}$ allele.

\begin{tabular}{|c|c|c|c|c|c|c|c|}
\hline SNP & $\begin{array}{l}\text { Nearest } \\
\text { gene }\end{array}$ & $\begin{array}{c}\text { No. of } \\
\text { participants }\end{array}$ & $\begin{array}{l}\text { Major allele / } \\
\text { Minor allele }\end{array}$ & MAF & $\begin{array}{c}\beta(\mathrm{cm} / \text { year }) \\
(95 \% \mathrm{CI})\end{array}$ & $\begin{array}{c}P \\
\text { value }\end{array}$ & $\begin{array}{c}\mathrm{Q} \\
\text { value }\end{array}$ \\
\hline \multicolumn{8}{|c|}{ Main effects* } \\
\hline rs1074078 & $m T O R$ & 6,566 & $\mathrm{G} / \mathrm{A}$ & 0.33 & $-0.05(-0.08 ;-0.01)$ & 0.007 & 0.7 \\
\hline rs10766383 & NUCB2 & 6,566 & $\mathrm{C} / \mathrm{A}$ & 0.28 & $0.05(0.01 ; 0.09)$ & 0.01 & 0.7 \\
\hline rs10493380 & $L E P R$ & 6,566 & $\mathrm{~A} / \mathrm{C}$ & 0.19 & $-0.05(-0.09 ;-0.01)$ & 0.02 & 0.7 \\
\hline rs7628795 & CCK & 6,566 & $\mathrm{G} / \mathrm{A}$ & 0.41 & $-0.04(-0.07 ;-0.004)$ & 0.03 & 0.7 \\
\hline rs11129949 & CCK & 6,566 & $\mathrm{~A} / \mathrm{C}$ & 0.12 & $0.05(0.01 ; 0.10)$ & 0.03 & 0.7 \\
\hline rs10832763 & NUCB2 & 3,723 & $\mathrm{~A} / \mathrm{G}$ & 0.36 & $0.06(0.01 ; 0.12)$ & 0.03 & 0.7 \\
\hline rs 12145690 & $L E P R$ & 6,566 & $\mathrm{~A} / \mathrm{C}$ & 0.45 & $0.03(0.001 ; 0.07)$ & 0.04 & 0.7 \\
\hline rs12700386 & $I L-6$ & 6,566 & $\mathrm{G} / \mathrm{C}$ & 0.19 & $0.04(0.0001 ; 0.07)$ & 0.04 & 0.7 \\
\hline \multicolumn{8}{|c|}{$\mathrm{SNP} \times \mathrm{GI}$ interaction ${ }^{+}$} \\
\hline rs7180849 & $N M B$ & 3,723 & G/A & 0.17 & $0.06(0.03 ; 0.09)$ & $5 \times 10^{-5}$ & 0.006 \\
\hline rs2025805 & $L E P R$ & 6,566 & G/A & 0.47 & $-0.02(-0.05 ;-0.004)$ & 0.02 & $>0.9$ \\
\hline rs9436746 & $L E P R$ & 6,566 & $\mathrm{C} / \mathrm{A}$ & 0.40 & $0.02(0.0003 ; 0.04)$ & 0.04 & $>0.9$ \\
\hline
\end{tabular}

SNP: Single nucleotide polymorphism; GI: Glycemic index; MAF: Minor allele frequency; $\beta$ : Regression coefficient; 95\% CI: 95\% Confidence interval.

* The models were adjusted for baseline age, weight and height, gender, follow-up time and smoking.

+ The model additionally included SNP, GI, SNP $\times$ GI, baseline waist circumference, physical activity, education level, alcohol intake, energy-adjusted residuals of fat, protein, carbohydrates and fiber, and for women, menopausal status and the use of hormone replace therapy.

No significant heterogeneity was observed for all the above mentioned associations $(P>0.16$ for all).

\section{Discussion}

In this large case-cohort study among Europeans from five countries, we studied the associations of SNPs in or near genes involved in food intake regulation of the hypothalamic signaling network with subsequent changes of weight and waist circumference. After adjustment for multiple testing, none of the SNPs under investigation showed a significant main effect on weight or waist circumference change. However, a significant interaction between the SNP rs7180849 (near NMB) 
and GI on both weight and waist circumference change was observed, suggesting a synergistic effect in promoting weight and waist gain.

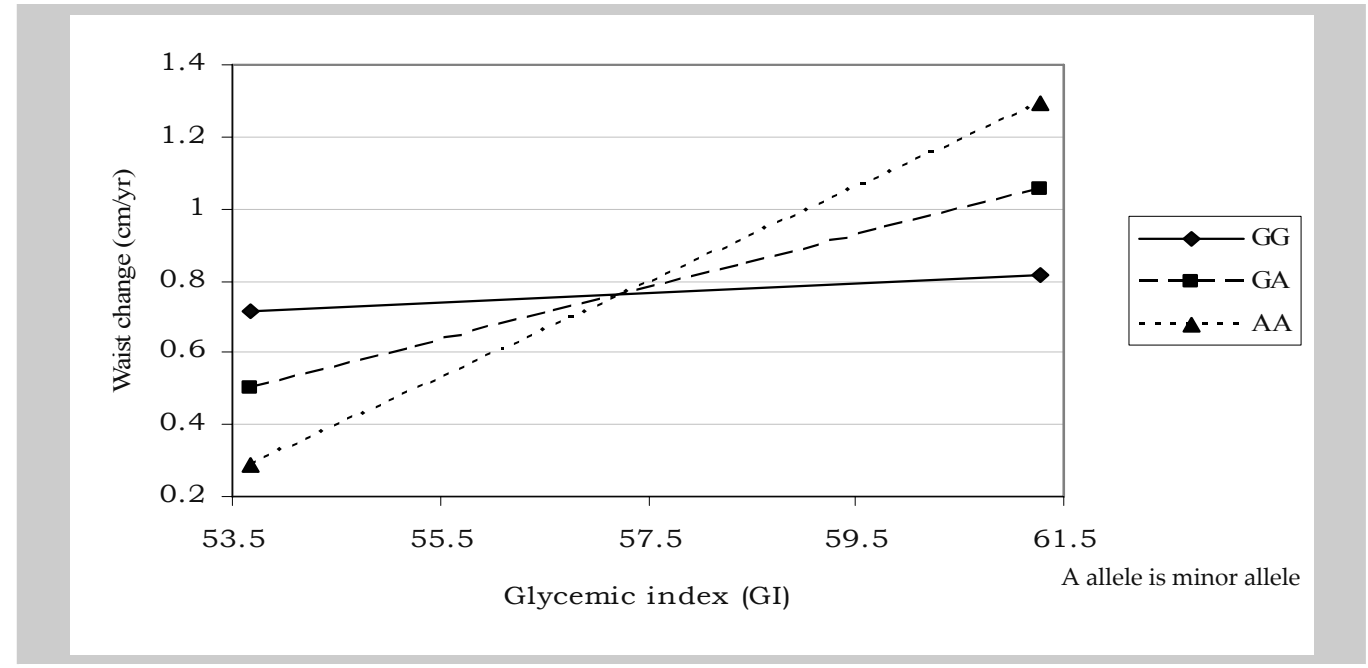

Figure 8-3. The regression of waist circumference change on GI by genotypes of the rs7180849 SNP.

The main strength of the current study includes its large scale, multi-center and prospective design. In addition, we selected SNPs to ensure full coverage of the genetic variation in candidate genes and standardized the nutritional and covariate variables to minimize the influences caused by various collecting methods used in different countries. The main weakness of the current study is the self-reported information on weight and waist circumference at follow-up in four out of six study centers. ${ }^{6}$ It has been observed in our previous studies using this data that correction for under-reporting using the available methods did not change the main findings. ${ }^{6}$ Although we have adjusted our analyses for many covariates, this may not be complete in terms of other potential confounders and changes in covariates such as physical activity levels and menopausal status.

The GI was introduced to replace the traditional classification of simple vs. complex carbohydrates based on the blood glucose response after consumption. Compared with high GI foods, low GI foods are absorbed more slowly, cause higher satiation and satiety thus reduce energy intake. ${ }^{5}$ Moreover, the lower postprandial glucose and insulin fluctuation could affect nutrient partitioning in a way that prohibits body fat storage. ${ }^{1,32}$ Findings from several clinical intervention studies and long term cohort studies have indicated a beneficial role of reducing dietary GI on promoting weight loss 33,34 and preventing weight and waist gain, ${ }^{35,36}$ including our own studies. ${ }^{6}$ However, findings are not completely consistent. We suspect that the discrepancy among studies and the heterogeneity observed in our own analyses might be partially attributed to the effects of genetic factors on adiposity gain in different populations. 
The critical role of energy intake regulation and the hypothalamic signaling network in weight change and obesity has long been recognized.20 A number of studies observed associations between genetic variations in this pathway and obesity-related phenotypes. ${ }^{9}, 11,12,37,38$ However, in the present large European casecohort study, we did not observe significant main effects with weight and waist change for the SNPs under investigation. Previous studies suggest that the level of BMI and weight change might be influenced by different genetic variants. ${ }^{13,} 39$ In contrast to the well-established heritability of obesity, the genetic influence of weight change in adults is less well characterized. ${ }^{40}$ For example, although the impacts of genes such as FTO and MC4R on body fat and BMI have been well identified, their role in weight change regulation has yet to be assessed. A relatively low statistical power for those SNPs with low minor allele frequencies might also partly explain the null finding. In addition, our results might be too conservative since we used a random effects meta-analytical approach to analyze our data. ${ }^{31}$ Similarly, in the genome-wide associations studies conducted so far, only a limited number of SNPs have been identified as being obesity-associated. Together they explain only a small proportion of the variation in $\mathrm{BMI}^{41}$ despite the fact that a heritability of obesity of $40-70 \%$ has been established. This "heritability gap" also exists for many traits and other chronic diseases, ${ }^{42,43}$ and might be due to the fact that many markers have to be discovered, some of which may locate in chromosome regions devoid of genes; or because in a polygenic condition like obesity, a single genetic polymorphism has only a small or null effect on the phenotype whereas the cumulative effects of genetic variants and complex interactions involve multiple genetic variants and multiple environmental factors need to be explored in a systematic way. ${ }^{37,}{ }^{4}$ Also, understanding the impacts of rare SNPs (population prevalence rate $<1 \%$ ), other types of variants, such as copy number variation, and epigenetics or DNA methylation patterns on the development of obesity or weight change is of importance. ${ }^{41}$

In our sub-cohort analyses, a significant interaction between GI and SNP rs7180849 (near $N M B$ ) was observed. This interaction was marginally significant in case-non case analyses $(P=0.003, Q=0.4)$. However, no significant main effect of this SNP on weight or waist circumference change was observed. As previously illustrated by Perusse and Bouchard, it is possible that gene-environment interactions exist while there is no direct genetic effect on disease risks. ${ }^{45}$ A similar situation has been observed in other studies as well, for example in the Nurses' Health Study, Pro12Ala polymorphism in the peroxisome proliferator-activated receptor gamma (PPAR $\gamma$ ) gene was not directly associated with BMI but this variant modified the relationship between total fat intake and BMI. ${ }^{46}$ The observed associations between GI, rs7180849 near the $N M B$, and subsequent changes of weight and waist circumference, yet to be replicated by other studies, may indicate that this SNP per se does not cause weight and waist gain directly, but can exacerbate the deleterious effects of high GI diets. 
NMB is a decapeptide that belongs to the bombesin-like peptide family and is widely distributed in the human central nervous system (CNS), pancreas, adrenals, gastrointestinal tract and adipose tissue. ${ }^{26}$ Evidence shows that NMB, released in the gastrointestinal tract in response to food intake, represents a mediator between the gut and the brain and serves as a satiation signal to terminate meals. ${ }^{26} \mathrm{NMB}$ is also expressed in adipose tissue and can act as an adiposity signal reflecting nutritional status and regulating food intake over a longer term.26, 27 Intravenous infusion of NMB has been shown to reduce meal size and meal duration in rats. ${ }^{47} \mathrm{~A}$ missense mutation p.P73T in the NMB has been associated with eating behaviors associated with obesity, including disinhibition (the tendency to overeat in response to different stimuli) and susceptibility to hunger (the perceived need for foods), and the amount of body fat gain during a 6-year follow-up in Quebec Family Study. ${ }^{38}$ In German children and adolescents, the silent polymorphism g.G401A in the NMB has been significantly associated with body weight. ${ }^{48}$ SNP rs7180849 is located at $\sim 3 \mathrm{~kb}$ upstream of the NMB (S-Figure 8-1) and is in absolute $\mathrm{LD}\left(\mathrm{r}^{2}=1.0, \mathrm{D}^{\prime}=1.0\right.$ in CEU Hapmap) with SNP rs3809508 which is positioned in the intron region of the NMB. There is no identified function of either rs7180849 or rs3809508 on NMB expression or obesity development so far. However, given the potential preventing role of $N M B$ on obesity and the observed positive interaction between rs7180849 and GI on weight and waist gain observed in our current study, we speculate that rs7180849, or rs3809508, is associated with lower $N M B$ expression. However, this hypothesis needs to be verified in experimental studies.

The current study reports for the first time that high GI diets may modify the effects of a genetic polymorphism on weight and waist change. Gathering more insight in interactions between genetic and dietary factors is critical for dietary counseling and interventions to be properly designed and targeted. However, during the last several decades, despite the identified obesity-associated genetic polymorphisms, ${ }^{49}$ interactions between these polymorphisms and dietary factors in the modulation of appetite, energy intake, and body weight and body composition change have been scarcely studied. Genome wide studies have their advantage in identifying genetic factors associated with complex diseases such as obesity, given the hypothesis free approach and full coverage of the entire genome. However, due to statistical and computational difficulties, testing gene-diet interactions has not yet been widely applied on a whole-genome scale.

To conclude, among this European population from five countries, none of the 123 SNPs in or near 15 candidate genes involved in the hypothalamic regulation pathway of food intake had a significant independent effect on the risk of weight and waist circumference gain. A SNP near the NMB (rs7180849) showed a significant interaction with dietary GI on subsequent weight and waist change. This finding may implicate that this polymorphism amplifies the impact of high GI diets on weight and waist circumference change, thus lowering dietary GI seems more important and effective for individuals with this genotype. However, given that the 
present study is the first to report this interaction, further studies are needed to verify this finding.

\section{References}

1. Du H, van der A DL, Feskens EJ. Dietary glycaemic index: a review of the physiological mechanisms and observed health impacts. Acta Cardiol. 2006;61(4):383-397.

2. Pereira MA. Weighing in on glycemic index and body weight. Am J Clin Nutr. 2006;84(4):677-679.

3. Howarth NC, Saltzman E, Roberts SB. Dietary fiber and weight regulation. Nutr Rev. 2001;59(5):129139.

4. Pereira MA, Ludwig DS. Dietary fiber and body-weight regulation. Observations and mechanisms. Pediatr Clin North Am. 2001;48(4):969-980.

5. Ball SD, Keller KR, Moyer-Mileur LJ, et al. Prolongation of satiety after low versus moderately high glycemic index meals in obese adolescents. Pediatrics. 2003;111(3):488-494.

6. Du H, van der A DL, van Bakel MM, et al. Dietary glycaemic index, glycaemic load and subsequent changes of weight and waist circumference in European men and women. Int J Obes (Lond). 2009:[Epub ahead of print].

7. Comuzzie AG, Allison DB. The search for human obesity genes. Science (New York, N.Y. 1998;280(5368):1374-1377.

8. Yang W, Kelly T, He J. Genetic epidemiology of obesity. Epidemiol Rev. 2007;29:49-61.

9. Rankinen T, Zuberi A, Chagnon YC, et al. The human obesity gene map: the 2005 update. Obesity (Silver Spring, Md. 2006;14(4):529-644.

10. Woods SC, Seeley RJ, Cota D. Regulation of food intake through hypothalamic signaling networks involving mTOR. Annual review of nutrition. 2008;28:295-311.

11. Baessler A, Hasinoff MJ, Fischer M, et al. Genetic linkage and association of the growth hormone secretagogue receptor (ghrelin receptor) gene in human obesity. Diabetes. 2005;54(1):259-267.

12. Loos RJ, Lindgren CM, Li S, et al. Common variants near MC4R are associated with fat mass, weight and risk of obesity. Nature genetics. 2008;40(6):768-775.

13. Silventoinen K, Kaprio J. Genetics of Tracking of Body Mass Index from Birth to Late Middle Age: Evidence from Twin and Family Studies. Obesity Facts. 2009;2(3):196-202.

14. Riboli E, Hunt KJ, Slimani N, et al. European Prospective Investigation into Cancer and Nutrition (EPIC): study populations and data collection. Public Health Nutr. 2002;5(6B):1113-1124.

15. Ferrari P, Day NE, Boshuizen HC, et al. The evaluation of the diet/disease relation in the EPIC study: considerations for the calibration and the disease models. Int J Epidemiol. 2008;37(2):368-378.

16. Slimani N, Deharveng G, Unwin I, et al. The EPIC nutrient database project (ENDB): a first attempt to standardize nutrient databases across the 10 European countries participating in the EPIC study. Eur J Clin Nutr. 2007;61(9):1037-1056.

17. van Bakel MM, Slimani N, Feskens EJ, et al. Methodological challenges in the application of the glycemic index in epidemiological studies using data from the European Prospective Investigation into Cancer and Nutrition. J Nutr. 2009;139(3):568-575.

18. Du H, van der A DL, van Bakel MM, et al. Glycemic index and glycemic load in relation to food and nutrient intake and metabolic risk factors in a Dutch population. Am J Clin Nutr. 2008;87(3):655-661.

19. Rinaldi S, Key TJ, Peeters PH, et al. Anthropometric measures, endogenous sex steroids and breast cancer risk in postmenopausal women: a study within the EPIC cohort. Int J Cancer. 2006;118(11):2832-2839.

20. Huda MS, Wilding JP, Pinkney JH. Gut peptides and the regulation of appetite. Obes Rev. 2006;7(2):163-182.

21. Friedman JM, Halaas JL. Leptin and the regulation of body weight in mammals. Nature. 1998;395(6704):763-770.

22. Wallenius $\mathrm{V}$, Wallenius $\mathrm{K}$, Ahren $\mathrm{B}$, et al. Interleukin-6-deficient mice develop mature-onset obesity. Nat Med. 2002;8(1):75-79. 
23. Cota D, Proulx K, Seeley RJ. The role of CNS fuel sensing in energy and glucose regulation. Gastroenterology. 2007;132(6):2158-2168.

24. Shimizu H, Oh IS, Okada S, et al. Nesfatin-1: An Overview and Future Clinical Application. Endocrine journal. 2009;56(4):537-543.

25. Coll AP, Loraine Tung YC. Pro-opiomelanocortin (POMC)-derived peptides and the regulation of energy homeostasis. Mol Cell Endocrinol. 2009;300(1-2):147-151.

26. Hoggard N, Bashir S, Cruickshank M, et al. Expression of neuromedin B in adipose tissue and its regulation by changes in energy balance. J Mol Endocrinol. 2007;39(3):199-210.

27. Spalova J, Zamrazilova H, Vcelak J, et al. Neuromedin beta: P73T polymorphism in overweight and obese subjects. Physiol Res. 2008;57 Suppl 1:S39-48.

28. Schwartz MW, Woods SC, Porte D, Jr., et al. Central nervous system control of food intake. Nature. 2000;404(6778):661-671.

29. Miller SA, Dykes DD, Polesky HF. A simple salting out procedure for extracting DNA from human nucleated cells. Nucleic Acids Res. 1988;16(3):1215.

30. Gauderman WJ, Morrison JM. QUANTO 1.1: A computer program for power and sample size calculations for gene-epidemiology studies (2006); http://hydra.usc.edu/gxe.

31. Higgins JP, Thompson SG, Deeks JJ, et al. Measuring inconsistency in meta-analyses. Bmj. 2003;327(7414):557-560.

32. Stevenson EJ, Williams C, Mash LE, et al. Influence of high-carbohydrate mixed meals with different glycemic indexes on substrate utilization during subsequent exercise in women. Am J Clin Nutr. 2006;84(2):354-360.

33. de Rougemont A, Normand S, Nazare JA, et al. Beneficial effects of a 5-week low-glycaemic index regimen on weight control and cardiovascular risk factors in overweight non-diabetic subjects. $\mathrm{Br} \mathrm{J}$ Nutr. 2007;98(6):1288-1298.

34. Thomas DE, Elliott E, Baur L. Low glycaemic index or low glycaemic load diets for overweight and obesity. Cochrane Database Syst Rev. 2007(3):CD005105.

35. Ma Y, Olendzki B, Chiriboga D, et al. Association between dietary carbohydrates and body weight. Am J Epidemiol. 2005;161(4):359-367.

36. Hare-Bruun H, Flint A, Heitmann BL. Glycemic index and glycemic load in relation to changes in body weight, body fat distribution, and body composition in adult Danes. Am J Clin Nutr. 2006;84(4):871-879; quiz 952-873.

37. Bouchard L, Tremblay A, Bouchard C, et al. Contribution of several candidate gene polymorphisms in the determination of adiposity changes: results from the Quebec Family Study. Int J Obes (Lond). 2007;31(6):891-899.

38. Bouchard L, Drapeau V, Provencher V, et al. Neuromedin beta: a strong candidate gene linking eating behaviors and susceptibility to obesity. Am J Clin Nutr. 2004;80(6):1478-1486.

39. Ortega-Alonso A, Sipila S, Kujala UM, et al. Genetic influences on change in BMI from middle to old age: a 29-year follow-up study of twin sisters. Behav Genet. 2009;39(2):154-164.

40. Hjelmborg JB, Fagnani C, Silventoinen K, et al. Genetic influences on growth traits of BMI: a longitudinal study of adult twins. Obesity (Silver Spring, Md. 2008;16(4):847-852.

41. Thorleifsson G, Walters GB, Gudbjartsson DF, et al. Genome-wide association yields new sequence variants at seven loci that associate with measures of obesity. Nat Genet. 2009;41(1):18-24.

42. Feero WG, Guttmacher AE, Collins FS. The genome gets personal--almost. JAMA. 2008;299(11):13511352.

43. Manolio TA, Collins FS, Cox NJ, et al. Finding the missing heritability of complex diseases. Nature. 2009;461(7265):747-753.

44. Heidema AG, Boer JM, Nagelkerke N, et al. The challenge for genetic epidemiologists: how to analyze large numbers of SNPs in relation to complex diseases. BMC genetics. 2006;7:23.

45. Perusse L, Bouchard C. Gene-diet interactions in obesity. Am J Clin Nutr. 2000;72(5 Suppl):1285S1290 S. 
46. Memisoglu A, Hu FB, Hankinson SE, et al. Interaction between a peroxisome proliferator-activated receptor gamma gene polymorphism and dietary fat intake in relation to body mass. Hum Mol Genet. 2003;12(22):2923-2929.

47. Rushing PA, Gibbs J, Geary N. Brief, meal-contingent infusions of gastrin-releasing peptide1-27 and neuromedin B-10 inhibit spontaneous feeding in rats. Physiol Behav. 1996;60(6):1501-1504.

48. Oeffner F, Bornholdt D, Ziegler A, et al. Significant association between a silent polymorphism in the neuromedin B gene and body weight in German children and adolescents. Acta diabetologica. 2000;37(2):93-101.

49. Willer CJ, Speliotes EK, Loos RJ, et al. Six new loci associated with body mass index highlight a neuronal influence on body weight regulation. Nature genetics. 2009;41(1):25-34. 
S-Table 8-1. List of the genes $(n=15)$ and SNPs $(n=134)$ selected for genotyping.

\begin{tabular}{|c|c|c|c|c|c|}
\hline Gene (chromosome) & SNPs & $\mathrm{N}^{*}$ & Position & Major allele/Minor allele & MAF \\
\hline \multirow[t]{9}{*}{ CCK $(\mathrm{chr} 3)$} & rs9311317 & 6 & 42270809 & $\mathrm{~A} / \mathrm{G}$ & 0.25 \\
\hline & rs10460960 & 6 & 42283738 & A / G & 0.11 \\
\hline & rs10865918 & 6 & 42278314 & $\mathrm{~A} / \mathrm{C}$ & 0.38 \\
\hline & rs11571842 & 6 & 42281449 & $\mathrm{G} / \mathrm{A}$ & 0.49 \\
\hline & rs11129949 & 6 & 42277811 & $\mathrm{~A} / \mathrm{C}$ & 0.12 \\
\hline & rs7474555 & 6 & 42280967 & $\mathrm{G} / \mathrm{A}$ & 0.24 \\
\hline & rs8192472 & 6 & 42274873 & $\mathrm{G} / \mathrm{A}$ & 0.38 \\
\hline & rs7628795 & 6 & 42270197 & $\mathrm{G} / \mathrm{A}$ & 0.41 \\
\hline & rs11129947 & 0 & & & Failed \\
\hline \multirow[t]{6}{*}{ CCKAR (chr 4) } & rs2000978 & 6 & 26097086 & $\mathrm{~A} / \mathrm{G}$ & 0.17 \\
\hline & rs7665027 & 6 & 26096006 & $\mathrm{~A} / \mathrm{G}$ & 0.15 \\
\hline & rs1573596 & 6 & 26090086 & $\mathrm{G} / \mathrm{A}$ & 0.47 \\
\hline & rs915889 & 6 & 26095291 & $\mathrm{G} / \mathrm{A}$ & 0.07 \\
\hline & rs2854030 & 6 & 26091118 & $\mathrm{G} / \mathrm{A}$ & 0.29 \\
\hline & rs1800855 & 0 & & & Failed \\
\hline \multirow[t]{13}{*}{ GHRL (chr 3) } & rs171336 & 6 & 10300749 & $\mathrm{C} / \mathrm{A}$ & 0.36 \\
\hline & rs35683 & 6 & 10303249 & $\mathrm{C} / \mathrm{A}$ & 0.48 \\
\hline & rs11718213 & 6 & 10300949 & $\mathrm{~A} / \mathrm{C}$ & 0.10 \\
\hline & rs35684 c & 5 & 10301685 & A / G & 0.28 \\
\hline & rs26802 & 6 & 10307364 & $\mathrm{~A} / \mathrm{C}$ & 0.33 \\
\hline & rs1617161 & 6 & 10311852 & $\mathrm{G} / \mathrm{A}$ & 0.11 \\
\hline & rs27647 & 6 & 10307467 & A / G & 0.40 \\
\hline & rs17032621 & 6 & 10300637 & $\mathrm{~A} / \mathrm{G}$ & 0.14 \\
\hline & $\mathrm{rs} 1629816^{\mathrm{d}}$ & 2 & 10311290 & $\mathrm{G} / \mathrm{A}$ & 0.38 \\
\hline & rs10490815 & 6 & 10310144 & A / G & 0.29 \\
\hline & rs3755777 & 6 & 10308363 & $\mathrm{G} / \mathrm{C}$ & 0.25 \\
\hline & rs2619507 & 6 & 10310785 & A / G & 0.16 \\
\hline & rs4684677 & 0 & & & Failed \\
\hline \multirow[t]{3}{*}{ GLP-1 (chr 2) } & rs3761656 & 6 & 162719480 & $\mathrm{~A} / \mathrm{C}$ & 0.08 \\
\hline & rs13416088 & 6 & 162705904 & $\mathrm{G} / \mathrm{A}$ & 0.21 \\
\hline & rs1990761 & 0 & & & Failed \\
\hline $5-H T_{1 A}(\operatorname{chr} 5)$ & rs1423691 & 6 & 63287417 & $\mathrm{~A} / \mathrm{G}$ & 0.50 \\
\hline \multirow[t]{7}{*}{ IL-6 (chr 7) } & rs2069827e & 2 & 22731980 & $\mathrm{C} / \mathrm{A}$ & 0.09 \\
\hline & rs2069840 & 6 & 22735096 & $\mathrm{G} / \mathrm{C}$ & 0.34 \\
\hline & rs12700386 & 6 & 22729533 & $\mathrm{G} / \mathrm{C}$ & 0.19 \\
\hline & rs10242595 & 6 & 22740755 & G / A & 0.32 \\
\hline & rs2069861 & 6 & 22738178 & $\mathrm{G} / \mathrm{A}$ & 0.09 \\
\hline & rs1800795 & 6 & 22733169 & $C / G$ & 0.41 \\
\hline & rs2069837 & 6 & 22734551 & A / G & 0.08 \\
\hline \multirow[t]{2}{*}{ LEP (chr 7) } & rs11763517 & 6 & 127677297 & A / G & 0.49 \\
\hline & rs3828942f & 3 & 127681540 & $\mathrm{G} / \mathrm{A}$ & 0.45 \\
\hline
\end{tabular}


SNPs and Changes of Weight and Waist Circumference |

\begin{tabular}{|c|c|c|c|c|c|}
\hline & rs2071045 & 6 & 127680215 & A / G & 0.24 \\
\hline & rs2278815 & 6 & 127669086 & A / G & 0.43 \\
\hline & rs11760956 & 6 & 127678322 & G/A & 0.37 \\
\hline & rs7788818 & 6 & 127681119 & G / A & 0.06 \\
\hline \multirow[t]{36}{*}{ LEPR (chr 1) } & rs1137101 g & 2 & 65831100 & A / G & 0.46 \\
\hline & rs1022981 & 6 & 65772621 & A / G & 0.25 \\
\hline & rs1137100 & 6 & 65809028 & A / G & 0.24 \\
\hline & rs7516341 & 6 & 65860730 & A / G & 0.37 \\
\hline & rs1892534 & 6 & 65878531 & G / A & 0.38 \\
\hline & rs1892535 & 6 & 65869768 & G/A & 0.18 \\
\hline & rs3790426 & 6 & 65815606 & $\mathrm{C} / \mathrm{A}$ & 0.24 \\
\hline & rs9436746 & 6 & 65681060 & $\mathrm{C} / \mathrm{A}$ & 0.40 \\
\hline & rs970467 & 6 & 65679349 & G / A & 0.11 \\
\hline & rs1045895 & 6 & 65670568 & G/A & 0.40 \\
\hline & rs10493380 & 6 & 65818704 & $\mathrm{~A} / \mathrm{C}$ & 0.19 \\
\hline & rs6588147 & 6 & 65708081 & A / G & 0.32 \\
\hline & rs2025805 & 6 & 65722465 & G / A & 0.47 \\
\hline & rs3790433 & 6 & 65666929 & G / A & 0.26 \\
\hline & rs1171279 & 6 & 65761080 & G/A & 0.27 \\
\hline & rs1171267 h & 4 & 65776441 & $\mathrm{C} / \mathrm{A}$ & 0.34 \\
\hline & rs11208659 & 6 & 65751867 & A / G & 0.10 \\
\hline & rs6704167 ${ }^{i}$ & 5 & 65710467 & $\mathrm{~A} / \mathrm{T}$ & 0.45 \\
\hline & rs1171278 & 3 & 65760733 & G / A & 0.18 \\
\hline & rs12409877 & 6 & 65716459 & G / A & 0.39 \\
\hline & rs8179183 & 6 & 65848539 & G / C & 0.18 \\
\hline & rs6662904 & 6 & 65770327 & G/A & 0.48 \\
\hline & rs3806318 c & 5 & 65657944 & A / G & 0.28 \\
\hline & rs4655537 & 6 & 65831388 & G/A & 0.36 \\
\hline & rs9436301 & 6 & 65668514 & A / G & 0.24 \\
\hline & rs4655802 & 6 & 65660818 & A / G & 0.41 \\
\hline & rs12145690 & 6 & 65659600 & $\mathrm{~A} / \mathrm{C}$ & 0.45 \\
\hline & rs1887285 & 6 & 65670334 & A / G & 0.09 \\
\hline & rs9436740 & 6 & 65664488 & $\mathrm{~T} / \mathrm{A}$ & 0.28 \\
\hline & rs11585329 & 6 & 65846401 & $\mathrm{C} / \mathrm{A}$ & 0.15 \\
\hline & rs 3762274 k & 5 & 65836700 & A / G & 0.39 \\
\hline & rs6673324 & 6 & 65803650 & A / G & 0.49 \\
\hline & rs10158579 & 6 & 65722643 & A / G & 0.13 \\
\hline & rs9436297 & 6 & 65661441 & A / G & 0.14 \\
\hline & rs6672331 & 6 & 65748434 & G/C & 0.03 \\
\hline & rs9436302 & 0 & & & Failed \\
\hline \multirow[t]{3}{*}{ MC4R (chr 18) } & rs11872992 & 6 & 56191566 & G / A & 0.13 \\
\hline & rs8093815 & 6 & 56187482 & G / A & 0.31 \\
\hline & rs1943226 & 6 & 56186183 & $\mathrm{~A} / \mathrm{C}$ & 0.10 \\
\hline
\end{tabular}




\begin{tabular}{|c|c|c|c|c|c|}
\hline & rs1943220 & 0 & & & Failed \\
\hline & rs17066846 & 0 & & & Failed \\
\hline \multirow[t]{4}{*}{ mTOR (chr 1) } & rs $1770345^{a}$ & 2 & 11137166 & $\mathrm{~A} / \mathrm{C}$ & 0.47 \\
\hline & rs1074078 & 6 & 11249374 & $\mathrm{G} / \mathrm{A}$ & 0.33 \\
\hline & rs12732063 & 6 & 11113818 & $\mathrm{G} / \mathrm{A}$ & 0.05 \\
\hline & rs1057079 b & 3 & 11127644 & A / G & 0.26 \\
\hline \multirow[t]{5}{*}{$N M B(\operatorname{chr} 15)$} & rs7180849 c & 5 & 82996662 & $\mathrm{G} / \mathrm{A}$ & 0.17 \\
\hline & rs2292462 & 6 & 83001757 & $\mathrm{~A} / \mathrm{C}$ & 0.47 \\
\hline & rs17598561 ${ }^{1}$ & 4 & 82999609 & $\mathrm{G} / \mathrm{A}$ & 0.06 \\
\hline & rs1051168 & 6 & 83001523 & $\mathrm{C} / \mathrm{A}$ & 0.29 \\
\hline & rs309430 & 0 & & & Failed \\
\hline \multirow[t]{10}{*}{$N P Y(\operatorname{chr} 7)$} & rs16472 & 6 & 24300593 & $\mathrm{G} / \mathrm{A}$ & 0.09 \\
\hline & rs5574 & 6 & 24295657 & $\mathrm{G} / \mathrm{A}$ & 0.47 \\
\hline & rs9785023 & 6 & 24291533 & A / G & 0.50 \\
\hline & $\mathrm{rs} 16135^{c}$ & 5 & 24294444 & $\mathrm{G} / \mathrm{A}$ & 0.07 \\
\hline & rs16141 c & 5 & 24291283 & $\mathrm{~A} / \mathrm{C}$ & 0.49 \\
\hline & rs3025118 & 6 & 24294201 & $\mathrm{C} / \mathrm{A}$ & 0.04 \\
\hline & $\mathrm{rs} 16148^{c}$ & 5 & 24288862 & $\mathrm{~A} / \mathrm{G}$ & 0.34 \\
\hline & rs12700524 & 6 & 24287938 & $\mathrm{~A} / \mathrm{G}$ & 0.14 \\
\hline & rs16142 & 0 & & & Failed \\
\hline & rs2023890 & 0 & & & Failed \\
\hline \multirow[t]{12}{*}{ NUCB2 (chr 11) } & rs214075 & 6 & 17256992 & $\mathrm{C} / \mathrm{A}$ & 0.41 \\
\hline & rs10832763c & 5 & 17307778 & $\mathrm{~A} / \mathrm{G}$ & 0.36 \\
\hline & rs7127347 & 6 & 17257419 & $\mathrm{~A} / \mathrm{C}$ & 0.13 \\
\hline & rs2634462 & 6 & 17295702 & $\mathrm{G} / \mathrm{A}$ & 0.27 \\
\hline & rs10741725 & 6 & 17277372 & $\mathrm{C} / \mathrm{A}$ & 0.46 \\
\hline & rs214105 & 6 & 17270096 & $\mathrm{~A} / \mathrm{G}$ & 0.28 \\
\hline & rs757081 & 6 & 17308258 & $\mathrm{C} / \mathrm{G}$ & 0.32 \\
\hline & rs12419530 & 6 & 17262798 & $\mathrm{~A} / \mathrm{G}$ & 0.04 \\
\hline & rs214086 & 6 & 17255041 & $\mathrm{G} / \mathrm{C}$ & 0.42 \\
\hline & rs214082 & 6 & 17255965 & $\mathrm{G} / \mathrm{A}$ & 0.41 \\
\hline & rs10766383 & 6 & 17286373 & $\mathrm{C} / \mathrm{A}$ & 0.28 \\
\hline & rs1330 & 6 & 17272604 & $\mathrm{G} / \mathrm{A}$ & 0.33 \\
\hline \multirow[t]{9}{*}{ POMC (chr 2) } & rs6713532 & 6 & 25238336 & A / G & 0.23 \\
\hline & rs934778 & 6 & 25242727 & $\mathrm{~A} / \mathrm{G}$ & 0.30 \\
\hline & rs1866146 & 6 & 25234076 & $\mathrm{~A} / \mathrm{G}$ & 0.34 \\
\hline & rs6545975 & 6 & 25238988 & $\mathrm{~A} / \mathrm{G}$ & 0.39 \\
\hline & rs3769671 & 6 & 25243656 & $\mathrm{~A} / \mathrm{C}$ & 0.03 \\
\hline & rs6719226 & 6 & 25249515 & $\mathrm{G} / \mathrm{C}$ & 0.04 \\
\hline & rs7565877 & 6 & 25239567 & $\mathrm{~A} / \mathrm{G}$ & 0.11 \\
\hline & rs7565427 & 6 & 25239141 & $\mathrm{G} / \mathrm{A}$ & 0.13 \\
\hline & rs6734859 & 6 & 25233411 & $\mathrm{G} / \mathrm{A}$ & 0.13 \\
\hline PYY (chr 17) & rs3744419 & 6 & 39438166 & $\mathrm{G} / \mathrm{A}$ & 0.20 \\
\hline
\end{tabular}


SNPs and Changes of Weight and Waist Circumference |

\begin{tabular}{|r|l|l|l|l|l|}
\hline & rs1859223 & 6 & 39435090 & G / C & 0.16 \\
\hline & rs8079623 & 6 & 39382855 & G / C & 0.11 \\
\hline & rs1058046 & 6 & 39386056 & G / C & 0.33 \\
\hline & rs1662754 & 6 & 39381050 & A / T & 0.44 \\
\hline & rs9907468 & 6 & 39407614 & G / A & 0.10 \\
\hline & rs1618809 & 6 & 39421450 & G / A & 0.37 \\
\hline & rs1642598 & 0 & & Failed
\end{tabular}

5-HT1A: Serotonin receptor gene; MAF: Minor allele frequency

* Number of study centers for which the SNP information was available, 0 means either genotyping failed or the SNP did not pass the predefined quality control.

a. Available in Italy and the UK. b. Available in Italy, Germany and Denmark. c. Available in 5 center in 4 countries

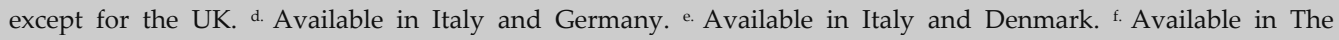
Netherlands (2 centers) and Germany. g. Available in the 2 center in The Netherlands. h. Available in Italy, The Netherlands ( 2 centers) and Denmark. i. Available in 5 center in 4 countries except for Germany. j. Available in Italy, UK and Germany. ${ }^{k}$. Available in 5 center in 4 countries except for Denmark. ${ }^{1}$. Available in 4 countries except for The Netherlands. 
Chapter 8

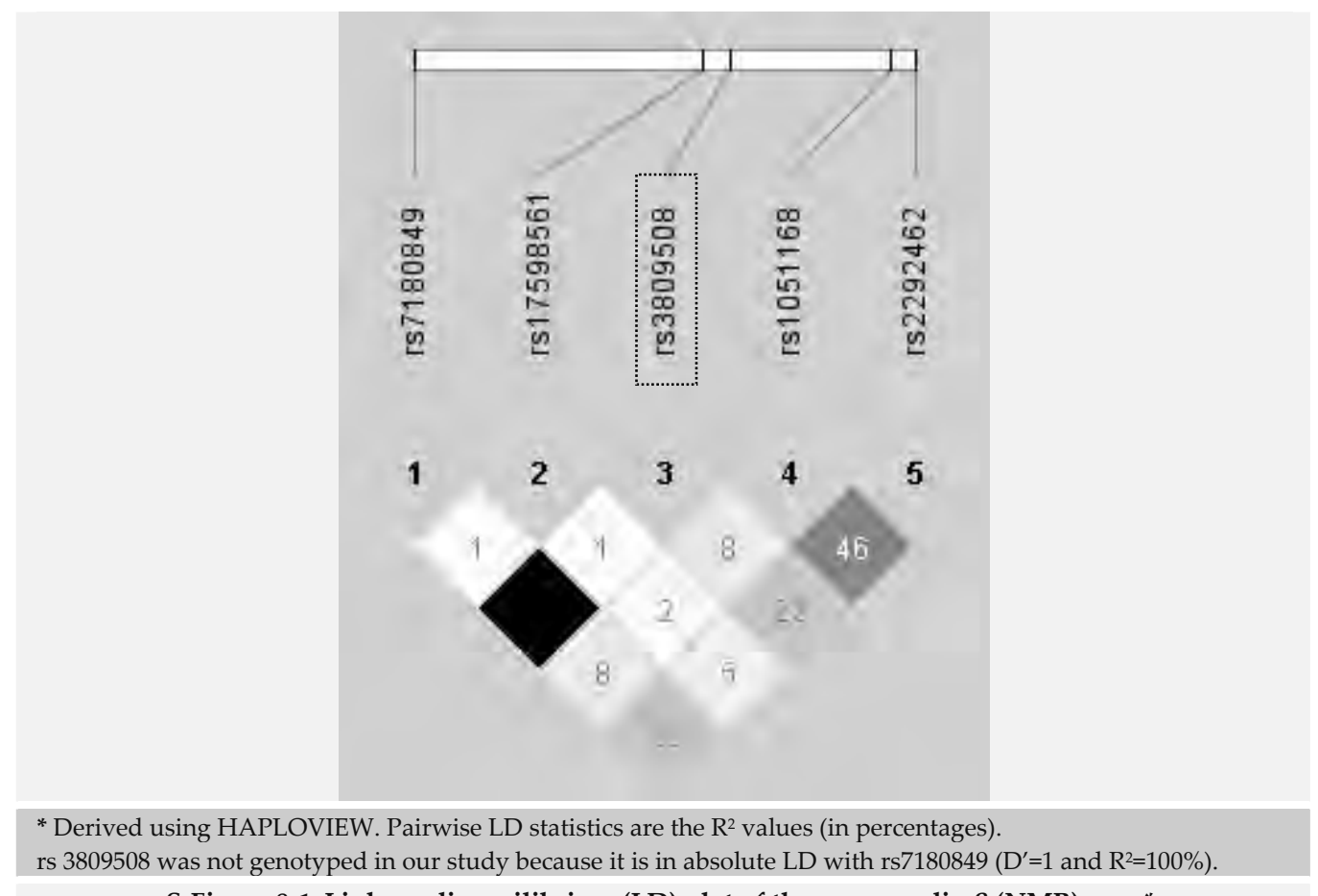

S-Figure 8-1. Linkage disequilibrium (LD) plot of the neuromedin $\beta$ (NMB) gene*. 


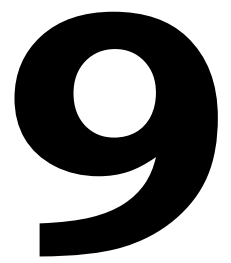

\section{General discussion}

The main aim of the research described in this thesis was to investigate the impact of diets with different glycemic indices (GI), glycemic loads (GL), fiber contents, fiber sources, and energy density (ED) on the subsequent changes of weight and waist circumference in a large sample of European populations followed for an average of 6.5 years. In addition, the evidence and underlying mechanisms of the potential health effects of low GI diets were reviewed, and the ability to assess dietary GI and GL using a food frequency questionnaire (FFQ) was evaluated. In this last chapter, the main findings and interpretations will be reviewed, methodological issues and possible public health messages will be discussed, and recommendations for future nutrition research, especially epidemiological research, in the area of obesity will be given.

\section{Main Findings and Interpretations}

GI is a relative measure of dietary carbohydrates' potential to raise blood glucose after consumption. It is a rather new concept introduced in the early 1980s, but the boom in etiological research started since late 1990s. ${ }^{1}$ To better understand this concept and the physiological mechanisms underlying the potential health effects of diets with different GI values, and to give an update on the evidence for the beneficial impact of low GI diets on chronic diseases, a detailed literature review was performed. As concluded in chapter 2, it is plausible that low GI diets favorably influence the management and prevention of type 2 diabetes, obesity, cardiovascular diseases and certain types of cancer. However, findings are yet far from consistent. ${ }^{2}$

As stated earlier, the main aim of this thesis work was to investigate the impact of dietary factors, assessed by food frequency questionnaires (FFQs), on subsequent weight and waist change in a large sample of Europeans from five countries participating in the EPIC study (European Prospective Investigation into Cancer and Nutrition). These dietary factors include GI as well as GL, which is a measure of the entire glycemic burden of a food or a diet and combines the quality (GI) and quantity of carbohydrates. ${ }^{3}$ However, the FFQs used in the EPIC study were not specially designed to measure dietary GI and GL, and their validity had never been assessed before. Therefore, it is critical to obtain insights into the quality of the GI and GL measurements before associating them to weight and waist change. Two studies were conducted to address this issue. 
Firstly, in a cross-sectional analysis of 974 participants from two ongoing Dutch cohort studies (the CoDAM study and the Hoorn study), we investigated the association of GI, GL with blood concentrations of metabolic risk factors (Chapter 3). We chose these two cohorts because they used the same FFQ to estimate habitual diets as the Dutch arms of the EPIC study. We observed a significant association of GI with fasting insulin, HOMA-IR, HDL cholesterol, total/HDL cholesterol ratio, and C-reactive protein (CRP). However, no significant association was observed between GL and any of the metabolic factors under investigation. ${ }^{4}$ Our findings support the beneficial role of low GI diets in preventing metabolic syndrome, insulin resistance, type 2 diabetes, and cardiovascular diseases. More importantly, they may also suggest a good validity of GI measured by this FFQ. ${ }^{5}$

Secondly, using the original data used to validate the Dutch EPIC FFQ, ${ }^{6,7}$ we examined the reproducibility and relative validity of GI and GL (Chapter 4). The interclass correlation coefficients between the three repeated FFQ measurements of GI and GL were 0.78 and 0.74 respectively, indicating a good reproducibility. Correlation coefficients between the FFQ measurements and the weighted averages of twelve 24-hour dietary recalls were 0.63 for both GI and GL, which indicates a satisfactory relative validity. ${ }^{8}$

\begin{tabular}{|c|c|c|c|}
\hline Ch. & Dietary exposures & $\begin{array}{l}\beta \text { on annual weight change } \\
\qquad(95 \% \mathrm{CI})\end{array}$ & $\begin{array}{c}\beta \text { on annual waist circumference } \\
\text { change }(95 \% \mathrm{CI})\end{array}$ \\
\hline \multirow{2}{*}{5} & Glycemic index $(\mathrm{GI})^{*}$ & $34(-47,115)$ & $0.19(0.11,0.27)$ \\
\hline & Glycemic load (GL) ${ }^{+}$ & $10(-65,85)$ & $0.06(-0.01,0.13)$ \\
\hline 6 & Energy density $(\mathrm{ED}) \ddagger$ & $-42(-112,28)$ & $0.09(0.01,0.18)$ \\
\hline \multirow{3}{*}{7} & Total dietary fiber\| & $-39(-71,-7)$ & $-0.08(-0.11,-0.05)$ \\
\hline & Cereal fiber\| & $-77(-127,-26)$ & $-0.10(-0.18,-0.02)$ \\
\hline & Fruit \& vegetable fiber\| & $2(-40,44)$ & $-0.08(-0.15,-0.01)$ \\
\hline \multicolumn{4}{|c|}{$\begin{array}{l}\beta \text { : Regression coefficient; CI: Confidence interval. } \\
{ }^{*} \text { The effects were for } 10 \text { units of GI; }{ }^{+} \text {The effects were for } 50 \text { units of GL; }{ }^{\ddagger} \text { The effects were for } 1 \mathrm{kcal} / \mathrm{g} \text { of ED. } \| \\
\text { The effects were for } 10 \mathrm{~g} / \text { day of fiber. } \\
\text { Heterogeneity among study centers was significant for all except for total dietary fiber on waist circumference } \\
\text { change. }\end{array}$} \\
\hline
\end{tabular}

Chapter 5, 6 and 7 present the results on the main effects of the dietary factors on subsequent changes of body weight and waist circumference. As shown in Table 9-1, neither GI nor GL was significantly associated with weight change. GI, but not GL, was significantly and positively associated with annual waist circumference (Chapter 5). ${ }^{9}$ ED was not significantly associated with weight change either, but it was significantly and positively associated with the change in waist circumference (Chapter 6). ${ }^{10}$ Both total dietary fiber and cereal fiber were significantly and inversely associated with subsequent weight and waist change, while fiber from fruits and vegetables was only inversely associated with waist change, not weight change 
(Chapter 7). These observed associations confirm some, but not all, earlier findings ${ }^{11-}$ 14 and suggest a beneficial role of low GI, high fiber, and low ED diets in the prevention of excessive weight and waist gain. However, the regression coefficients were rather small especially when viewed from the individual level. This may be partly due to the under-reporting of energy intake, ${ }^{15}$ which is more pronounced among obese individuals. This notion was supported by a stronger association between ED and waist change in non-obese $\left(\mathrm{BMI}<25 \mathrm{~kg} / \mathrm{m}^{2}\right)$ compared to the association in overweight or obese participants $(0.17 \mathrm{~cm} /$ year vs. $0.04 \mathrm{~cm} /$ year for 1 $\mathrm{kcal} / \mathrm{g}$ ED) (Chapter 6). ${ }^{10}$

In Chapter 8, we examined the impact of several single nucleotide polymorphisms (SNPs) on subsequent weight and waist change. We focused on SNPs in or near genes involved in the hypothalamic signaling network, which plays a critical role in the regulation of satiation and satiety and thus energy intake. The potential interaction between these SNPs and GI was also investigated. None of the SNPs under investigation was directly associated with weight or waist change. A significant interaction between GI and rs7180849, a SNP near the neuromedin $\beta$ (NMB) gene, on both weight and waist change was observed. Minor allele carriers seemed to be more sensitive to the impact of dietary GI on weight and waist change than no carriers. This finding implicates that following a low GI diet might be of special importance for people carrying minor allele of this SNP. However, further studies are needed to verify this finding.

\section{Methodological Considerations}

In this paragraph we discuss several general methodological issues, from study design and study populations to exposure and outcome assessments and statistical methods. This discussion will further elaborate the strengths and weaknesses of our studies and will provide a general interpretation of the associations between dietary factors and body weight and waist circumference change observed in this thesis.

\section{Study design}

Observational study

Mainly due to the limitations of observational studies, such as uncontrolled confounding, findings from randomized controlled trials (RCTs) are generally believed to provide the highest level of evidence. ${ }^{16}$ However, conducting large-scale, long-term, well-controlled RCTs examining the effects of dietary factors on weight change is extremely difficult, sometimes even impossible, due to the obstacles in costs, logistics, and ethical issues. ${ }^{16}$

Conducting RCTs on weight gain prevention is even more difficult, given the chronic process of weight gain and the long-term nature of such trials leading to difficulties in compliance. In addition, weight gain in a certain time period may be small and with a large inter-individual variation. Also, many factors can contribute to weight gain (see Chapter 1) and the impact of any individual factor (the 
intervention) would be small. These two aspects necessitate a very large sample size for sufficient statistical power of detecting a significant effect. Therefore, most of the RCTs focused on diet-induced weight loss instead of weight gain. However, not all diets promoting weight loss among obese individuals are appropriate for a longterm use to prevent weight gain, such as the well-known very-low-carbohydrate diet. ${ }^{17-19}$ Some of the RCTs, for instance the one within the DiOGenes project, ${ }^{20}$ investigated the role of dietary interventions in preventing weight regain after a period of quick weight loss, which might be considered as a proxy of weight gain. However, evidence from both animal and human studies has shown that strict energy restriction and quick weight loss are usually accompanied by several metabolic, behavior and psychological adaptations, for example a decreased leptin level and an increased cortisol level, leading to a reduced energy expenditure and an increased appetite (hyperphagia), ${ }^{21,22}$ an enhanced preference for highly palatable high fat energy dense foods, ${ }^{22-24}$ and prioritized carbohydrate oxidation leading to a retention of fat for the formation of the visceral adipose tissue. ${ }^{25}$ Therefore, strategies for weight regain prevention may not be exactly the same as those for preventing weight gain.

In spite of the weaknesses, observational studies have specific strengths, such as a large sample size thus an enhanced statistical power and a longer follow-up time, in the case of cohort studies, which enables researchers to investigate the long-term effects of multiple dietary factors independently and interactively. The results of population-based observational studies could be easily generalized as they are based on the natural development of a trait in a real-life situation.

\section{Prospective study}

Associations observed in cross-sectional studies can be affected by reverse causality, which means some participants may change their exposure status due to the presence of outcome. For example, in studies of diet and adiposity associations, participants may have switched their dietary behavior due to obesity. This phenomenon limits our capability to interpret the research findings. Moreover, underreporting of energy, in particular fat and sugar, ${ }^{26,27}$ intake is clearly related to the degree of obesity and could distort the diet - body weight association under investigation. ${ }^{28}$ As we have mentioned in previous chapters, the prospective design is one of the main strengths of our studies, besides the large sample size. However, we could not rule out the possibility that what we were investigating is only the tail of the real association. Weight (and also waist) gain is a chronic process and the largest rate among adults occurs during early adulthood. Body weight tends to level off or even decline during the later years of life (60+ years). ${ }^{29}$ In our study, mean baseline age of the participants is around 55 years, which means that most of the participants have already put on a considerable amount of body fat during the first half of their lives. This might partly explain the small effects we have observed. 


\section{Heterogeneous study population}

Our study participants came from five different European countries. Multicentre studies have been considered of special strength through enlarged interindividual differences in both exposures and outcomes, thereby creating a larger statistical power. In addition, conclusions drawn from studies with heterogeneous populations generally have a larger generalizibility. ${ }^{20}$ However, there can also be inherited limitations, such as the different methodologies used to collect habitual diets. Using country-specific food frequency questionnaires (FFQs) to assess diets is necessary, due to the differences in eating patterns, nutrient composition and availabilities of foods, language, and so on. However, different FFQs may have considerably distinct reproducibility and validity. ${ }^{30}$ In addition, different food composition tables also induce measurement errors when different methods are used to analyze the nutrient values. In the EPIC study, extensive efforts have been made to improve the comparability of the dietary variables as well as other important lifestyle factors, such as physical activity. For example, foods consumed in different countries were classified into the same food groups; nutrient values, i.e. fiber intake, analyzed using different methods were standardized; a linear regression calibration was performed to reduce the country-specific measurement errors and to further improve the comparability of dietary variables. For the latter, we regressed the intake of foods and nutrients measured by the FFQs on the 24-hour recall data collected using the standardized EPIC-SOFT program. ${ }^{31,32}$ Nutrient intake in the 24hour recall data was calculated using a standardized nutrient database. ${ }^{33}$ The downside of this calibration practice is the potential of bias caused by the fact that the reference 24-hour recall data was collected only once. This may cause bias in terms of representing long-term habitual diets, and the errors in the 24-hour recall and the FFQs can be correlated. However, Kaaks et al in a methodological review have concluded that: " ... a calibration study based on only a single day's food intake record (but generally on a larger number of subjects) can provide sufficient reference information to correct relative risk estimates for biases due to measurement error"; "A major advantage of calibration studies based on this single-day-per-subject design is that they can be conducted on a representative sample of cohort participants more easily than validity studies in which reference measurements are repeated" ${ }^{34}$ I our studies, we have taken the uncertainty in calibrated data into account by performing sensitivity analyses with un-calibrated dietary variables (Chapter 5, 6 and 7).

\section{Measurement errors in exposures and outcomes}

As has been discussed in the individual chapters (Chapter 5, 6, and 7), measurement errors likely to occur in both dietary and anthropometric variables. The error in self-measured anthropometrics might be relatively easy to prevent, whereas the measurement error in dietary variables at present is a great concern in nutritional research. In most of the epidemiological studies, energy, particularly fat 
and sugar, intake is underreported.26, 27 This underreporting is usually not random and is significantly greater among those with higher BMI. Other factors such as gender and weight-consciousness are also related to energy under-reporting. ${ }^{35,36}$ In our study, dietary variables including total energy, food and nutrient intake estimated using FFQs have been validated against a reference method, such as multiple 24-hour recalls, weighted food records and biomarkers., ${ }^{4,30}$ However, given the fact that most of the dietary variables were only validated against a reference method which may have related measurement errors with the FFQs, the validity estimates might be overestimated.

Differential underreporting may distort the association between energy intake and body weight. Given the prospective design of our current study, underreporting of total energy in our study might not be directly related to weight change, since the dietary information was collected prior to the occurrence of weight change. However, it is likely that an indirect effect through baseline weight is present. Therefore, it is critical to adjust for measurement error in data analyses, ${ }^{15}$ for which multiple strategies have been applied. Firstly, energy-adjusted residuals of dietary variables (both the exposure and confounding variables) have been used. This method has been recognized as the major analytical technique in nutritional epidemiology to correct for measurement errors in dietary variables of interest. ${ }^{36,37}$ Secondly, a linear regression calibration has been performed. In addition, we have adjusted our analyses for baseline weight, height, and gender and explored the effect modification by baseline BMI and the ratio of energy intake to estimated basal metabolic rate. The application of these methods enhanced the reliability of our findings.

\section{Statistical methods}

In our study, we applied a random-effect meta-analytical approach for our data analysis. This is a two-stage process including separate analyses in each study center and pooling the center-specific estimates using random-effect models. ${ }^{37}$ This approach was chosen because of the heterogeneity across study centers observed in our study. Some may argue that we should use a combined analysis with an adjustment for center, since this study (the EPIC study) was designed and conducted as a single study carried out on different locations, and many efforts have been made to standardize the data. In addition, aggregated analyses could take a better advantage of the variations in exposures across whole study participants. ${ }^{37}$ However, the high amount of heterogeneity observed indicates the existence of significant differences with respect to the effects of dietary factors on weight and waist circumference change in participants from different study centers. Presenting a pooled estimate without mentioning the differences between centers is therefore inappropriate. With the meta-analytical approach, the regression models were run in each participating cohort separately, which allows exposure and covariates to be differently associated with the outcome in each center. Using the random-effects model to pool the results, we took heterogeneity into account through a larger 
standard error and a wider confidence interval. The estimates reported in our papers are therefore the most conservative ones in terms of both the magnitude of estimates and their significance. The unexplained heterogeneity observed in our findings may indicate that there are some factors, currently unknown to us, driving the differences and inviting further examination.

\section{Genetic Epidemiology}

Twin, adoption and family studies have indicated that common obesity has a genetic component as high as $40-70 \%{ }^{38}$ The DiOGenes project, under which the studies presented in this thesis were conducted, applied a hypothesis driven candidate gene approach to study the impact of genes on obesity. This approach involves the selection of genes that are a priori suspected to be involved in the development of obesity or weight change based on previous knowledge. With the completion of the International Human HapMap Project and the advances in highthroughput genotyping technologies, genome-wide association studies on chronic diseases including obesity have been increasingly conducted. ${ }^{39}, 40$ As compared to this hypothesis free approach, the most valuable aspect of the candidate gene approach lies in the opportunity of detailed analyses on the gene-gene and geneenvironment interactions. ${ }^{41}$

In our study on SNPs (Chapter 8), we investigated the effect of individual SNPs and their interactions with dietary GI on weight and waist change, without taking into account the cumulative effects of several SNPs or the SNP-SNP interactions. This is because our ultimate research objective was to understand the function of individual genes and genetic variants in obesity prevention, for the purpose of better targeting the obesity treatment and prevention interventions later. Common obesity is a polygenic trait, to which a single genetic polymorphism may have only a small, if not null, contribution, while the complex gene-gene and gene-environment interactions may play an important role. ${ }^{42,43}$ Analytical techniques investigating the genetic effects on weight change while at the same time taking into account the complex interactions, such as the random forest approach, might be of great importance in determining the genetic pool of obesity in future. ${ }^{44}$

\section{Public Health Relevance}

The continually increasing obesity prevalence has spurred many international and national public health agencies, such as the WHO, to provide public recommendations for halting this epidemic. Public recommendations should be evidence-based and findings from all types of studies, i.e. observational, mechanistic and randomized intervention studies, are needed. ${ }^{17}$ One of the strengths of our present prospective cohort studies is its population-based design, which means findings have higher generalizability. Several aspects should however be considered. 
Small effect sizes may have significant public health relevance. The effects of dietary factors on subsequent weight and waist circumference observed in the current thesis were generally small (Table 9-1). From an individual perspective, these effects are definitely of no relevance. However, results from epidemiological studies should be interpreted at population level instead of individual level. ${ }^{45}$ Some small effects size may have large public health consequences if the risk factors have high prevalence and the disease presents an important public health concern. From this point of view, our findings are of public health relevance because obesity is currently an important public health issue and western diets are usually energy dense, high in GI, and low in fiber. Furthermore, we have adjusted our analyses for a number of potential confounders to obtain independent effects of the main exposure. In real life, several dietary factors may be changed simultaneously. For example, when fiber intake is increased through switching from refined cereals to wholegrain cereals, dietary GI may also be decreased, and therefore the effects could be additive. More importantly, the mean annual weight and waist circumference change in our study population were $115 \mathrm{~g} /$ year and $0.76 \mathrm{~cm} /$ year respectively, and thus the effects of 39-77 g/year and 0.08-0.19 cm/year (Table 9-1) represent $34 \%-67 \%$ of the mean weight change and $11 \%-25 \%$ of the mean waist circumference change. Therefore, the effects observed in the present study are of public health relevance and best be considered at proportional instead of absolute scale when translated into the impact at the individual level.

Low glycemic index does not necessarily mean healthy. The debates on the GI concept have not yet come to a halt. ${ }^{46}$ Whether recommending a low GI diet could mislead consumers to follow a high fat - low carbohydrate diet is the main concern. There is no doubt that GI alone will not label a food as "healthy" or "unhealthy". For example, a chocolate bar can have a GI lower than 40 while a watermelon can have a GI around 80.47 The GI value of fructose $(\sim 20)$ is much lower than the GI value of glucose $(\sim 100)$, but this does not exclude the possibility that high fructose consumption could lead to a reduction in insulin sensitivity and increase in visceral adiposity and blood lipids. ${ }^{48}$ The public health messages regarding GI must be that the application of the GI should be in the context of the overall composition of the diet, focusing on the quality of starchy foods in particular, while other dietary factors, such as energy density and contents of fiber should also be taken into account. Low GI is not equal to healthy.

A high fiber, low glycemic index and low energy dense dietary pattern probably is beneficial in terms of prevention of weight and waist gain. Intake of foods and nutrients tend to be highly correlated in free-living people. This is not only the case for macronutrients (e.g. a low- or no-carbohydrate diet must be necessarily high in fat or protein), but also for other dietary factors, such as vitamin $C$ and fruit fiber. Although it is possible to calculate the independent impact of single dietary factors 
on disease outcome in statistical analyses, it is hardly possible to change only one or few nutrients in real life through the variation in meals. For example, choosing an apple instead of a candy bar as a snack may simultaneously increase the fiber content and decrease GI and ED of the diet. In addition, other valuable changes could also be achieved, such as increased vitamin and decreased fat intake. On the other hand, dietary recommendations should be based on dietary patterns rather than individual dietary factors. A cola drink ( $\mathrm{ED}=40 \mathrm{kcal} / 240 \mathrm{~g}=0.17$ ) can be low energy dense as compared to a banana $(\mathrm{ED}=80 \mathrm{kcal} / 100 \mathrm{~g}=0.8)$ which contains much more fiber and vitamins than the former. A balanced diet is critically important for a long-term weight control and a general health. Although we have observed only small effects for dietary fiber, ED and GI on weight and waist change, our findings suggest that a dietary pattern rich in fiber and low in GI and ED will be beneficial for preventing body weight and waist gain. Further studies investigating the association of this dietary pattern with weight and waist change as well as other obesity-related chronic conditions such as type 2 diabetes, cardiovascular diseases, certain cancers and mortality are of interest. To be able to achieve this dietary pattern, people should increase their consumption of whole-grain based cereal, pasta and bread especially focusing on the low GI variants such as rye breads, consume more legumes, fruits, and vegetables, and limit total fat intake.

The glycemic load (GL) deserves some further discussion. As a concept introduced to capture the total glycemic burden of foods or diets by combining both the quality (GI) and quantity of carbohydrates, GL has more physiological meaning than GI. However, in epidemiological studies like ours, GL is often highly correlated with total carbohydrate intake, which makes it difficult to distinguish the impact of these two variables. In real life setting, understanding what GL means could guide us to choose a low GI diet. For example, for foods rich in carbohydrates (e.g. rice and breads), more attention should be paid on their GI values, since even a small bite will contribute substantially to the overall dietary GI and GL. On the other hand, if a food contains a limited amount of carbohydrates (i.e. water melon), its contribution to the overall dietary GI and GL will be minimal, even though it is of high GI.

A calorie is a calorie?! Although a significant beneficial effect of a low GI diet on waist circumference change was observed, as described in chapter 5, the effect of GL was not statistically significant, which means, as compared to low fat diets, low GL diets do not seem to be beneficial for preventing weight and waist circumference gain in an iso-caloric situation. This finding is in line with the proposition "a calorie is a calorie" in terms of weight change. ${ }^{49}$ Several recent intervention studies also draw a similar conclusion: weight loss and maintenance relies on calorie restriction and is independent of the macronutrient composition of the diet.50,51 However, in an earlier meta-regression of 87 studies, diets lower in carbohydrates have been associated with a larger weight loss regardless of total energy intake. ${ }^{52}$ In the Women's Health Initiative Dietary Modification Trial, a long term intervention trial 
on the prevention of cancer and cardiovascular diseases in postmenopausal women, weight loss was more pronounced among women who had the greatest decrease in percentage of energy from fat. ${ }^{29} \mathrm{In}$ a meta-analysis of 16 trials comparing ad libitum low-fat diets with a control group, the low-fat intervention group lost on average 3.2 $\mathrm{kg}$ more than the control group during the 2-12 months intervention periods. ${ }^{17}$ Although there is still room for debate about whether a calorie is indeed a calorie with respect to weight control, ${ }^{53-55}$ in any case moderate caloric restriction is beneficial in terms of preventing weight gain.

Personalized nutrition: an attractive perspective but it may prove problematic. In this thesis we observed that GI and a variant near neuromedin $\beta$ (NMB) gene interactively associated with both weight and waist circumference change (Chapter 8). This finding needs to be replicated and verified in future studies. In general, the exploration of how genetic polymorphisms interact with different dietary factors on weight change will help to understand the etiology of obesity and to fine-tune the targets of nutritional prevention and treatment. Personalized nutrition is a conceptual analogue of personalized medicine, meaning adapting diets to individual needs based on people's genotype or gene expression profile. This is a very attractive option for nutrition scientists as well as the general public. But, it should be a personal choice at best and may prove problematic if given as a public recommendation. First, our knowledge on gene-diet interactions still needs to be improved. The interactions may be proven too complex to be prescribed with simple understandable dietary advices as they may involve multiple genetic and dietary factors. Furthermore, there is a big knowledge-behavior gap in health promotion. Information on genetic predisposition may be of some use in motivating predisposed people to change their diets, but it can also counteract the effects of public health messages, by misleading the public that only those carrying "risk genes" need to care about their diets. Last but not the least, personalized nutrition may bring numerous ethical problems, such as discrimination and stigma, if it would become routine in practice. ${ }^{56}$

Other determinants of obesity should also be taken into account. As a common complex disorder, obesity or weight gain is associated with many factors, ${ }^{43}$ some of which are briefly mentioned in the General Introduction of this thesis. Although the main cause for becoming heavier might be different among individuals, preventing a positive energy balance through an increased physical activity and a decreased calorie intake probably is the core of obesity prevention for everybody. These behavior changes of individuals need a supportive environment to be able to sustain. For this the development of public policies that address obesity issues is very important. For example, some countries have already taken a lead in legislation on approaches to combat obesity, such as sugar-sweetened beverages have been taxed more than other commodities ${ }^{57}$ and banned from school vending machines. ${ }^{58}$ 
Currently, more investigation on the effectiveness these legislation strategies is needed.

\section{Future Research}

No results of epidemiological studies can be considered final. Future studies are definitely necessary to confirm or deny the findings in this thesis. With respect to large prospective cohort studies, more efforts should be paid to the detailed collection of information on body fatness, dietary exposures, genetic variants and other behavioral variables such as physical activity to be able to precisely address the issue of energy balance, which is the core of the obesity problem.

With regard to total body fat measurements, technologies such as computerized tomography (CT) and magnetic resonance imaging (MRI) might be of help when the financial and practical barriers could be overcome.59,60 These imaging techniques are especially useful for quantifying the distribution of abdominal adipose tissue as subcutaneous abdominal fat or visceral fat, which is helpful for the estimation of the risk of insulin resistance, type 2 diabetes and cardiovascular diseases.61,62 As a valid, simple and inexpensive approach to assess body fat status, especially in large populations, anthropometric measurements, such as waist circumference, waist-hipratio and sagittal diameter, ${ }^{63}$ need to be standardized in aspects such as clothing and fasting status of subjects and the sites of the measurements. ${ }^{64}$ Because it does not distinguish lean and fat body mass, BMI may not be a good indicator of adiposity at individual level. However, on a group basis, the BMI has been shown to be reasonably correlated with body fat content. ${ }^{65}$

Progress in the quality of dietary assessments will not only benefit obesity research, but also other areas of nutritional epidemiology, thus contributing to a better understanding and practicing of a 'healthy diet'.66 For example, improving the definition and determination methods for dietary fiber is definitely important from both scientific and public health perspectives. ${ }^{67}$ Enhancing the ability of dietary assessment tools to measure habitual GI and GL is necessary for comparing and translating the study findings and to solve the discussion on their utilities. For this, more foods should be tested for their GI values using a standard protocol. ${ }^{68}$ Specific dietary assessment tools should be designed focusing on carbohydrate-rich foods and collecting information on the nature of mono-, di- and polysaccharides, brands of products, fiber contents, preparation methods, how long the food is cooked, at what temperature it is consumed and with what foods together, and whether the breads contain intact kernels, etcerera. ${ }^{2}$ Accurately measuring dietary intake may become reality in the future, perhaps as a result of technological breakthroughs, improved statistical methods or robust biomarkers. ${ }^{69}$

Despite the large heritability of obesity established by family, adoption and twin studies, a very limited number of common variants have thus far been identified as obesity phenotype-associated. Further increasing the sample sizes or performing meta-analyses of human genetic studies, increasing the precision of phenotype 
measures, focusing on fat mass instead of BMI, studying fat distribution together with the total amount of fat tissue, obtaining more insights on the complex genegene and gene-environment interactions, ${ }^{44}$ and developing tools which allow us to identify rare variants (population frequency $<1 \%$ ), and other types of variants, such as copy number variation, should be the direction of future research. Further research is also needed to investigate the impact of epigenetics or DNA methylation patterns on the development of obesity or weight change. ${ }^{70}$ In addition, detailed information on genetic variants influencing gene expression and protein function need to be collected. Furthermore, genetic etiology of BMI or obesity may vary across the lifespan..$^{71}$ Therefore, lifelong follow-up studies on birth cohorts are of special interests for investigating the environmental, genetic, genetic and epigenetic influences on the development of obesity.

Improved knowledge and understanding the dietary and genetic determinants of obesity is only the first step of tackling the obesity problem. As mentioned earlier, there is still a large gap between knowledge and behavior changes. Research in finding effective methods, such as societal and environmental changes,,$^{72}$ to stimulate adaptations in dietary habits is vital for the translation of improved knowledge into healthy behaviors.

\section{References}

1. Buijsse B, Feskens EJ, Schulze MB, et al. Fruit and vegetable intakes and subsequent changes in body weight in European populations: results from the project on Diet, Obesity, and Genes (DiOGenes). Am J Clin Nutr. Jul 2009;90(1):202-209.

2. Du H, van der A DL, Feskens EJ. Dietary glycaemic index: a review of the physiological mechanisms and observed health impacts. Acta Cardiol. Aug 2006;61(4):383-397.

3. Salmeron J, Manson JE, Stampfer MJ, et al. Dietary fiber, glycemic load, and risk of non-insulindependent diabetes mellitus in women. Jama. Feb 12 1997;277(6):472-477.

4. Galisteo M, Duarte J, Zarzuelo A. Effects of dietary fibers on disturbances clustered in the metabolic syndrome. J Nutr Biochem. Feb 2008;19(2):71-84.

5. Liu S, Manson JE, Stampfer MJ, et al. Dietary glycemic load assessed by food-frequency questionnaire in relation to plasma high-density-lipoprotein cholesterol and fasting plasma triacylglycerols in postmenopausal women. Am J Clin Nutr. Mar 2001;73(3):560-566.

6. Ocke MC, Bueno-de-Mesquita HB, Goddijn HE, et al. The Dutch EPIC food frequency questionnaire. I. Description of the questionnaire, and relative validity and reproducibility for food groups. Int $J$ Epidemiol. 1997;26 Suppl 1:S37-48.

7. Ocke MC, Bueno-de-Mesquita HB, Pols MA, et al. The Dutch EPIC food frequency questionnaire. II. Relative validity and reproducibility for nutrients. Int J Epidemiol. 1997;26 Suppl 1:S49-58.

8. Du H, van der A DL, van Bakel MM, et al. Reproducibility and relative validity of dietary glycaemic index and glycaemic load assessed by the food-frequency questionnaire used in the Dutch cohorts of the European Prospective Investigation into Cancer and Nutrition. Br J Nutr. Aug 23 2009;102(4):601604.

9. Du H, van der A DL, van Bakel MM, et al. Dietary glycaemic index, glycaemic load and subsequent changes of weight and waist circumference in European men and women. Int J Obes (Lond). Aug 25 2009:[Epub ahead of print].

10. Du H, van der A DL, Ginder V, et al. Dietary energy density in relation to subsequent changes of weight and waist circumference in European men and women. Plos ONE. 2009;4(4):e5339. 
11. Hare-Bruun H, Flint A, Heitmann BL. Glycemic index and glycemic load in relation to changes in body weight, body fat distribution, and body composition in adult Danes. Am J Clin Nutr. Oct 2006;84(4):871-879; quiz 952-873.

12. Savage JS, Marini M, Birch LL. Dietary energy density predicts women's weight change over $6 \mathrm{y}$. Am J Clin Nutr. Sep 2008;88(3):677-684.

13. Bes-Rastrollo M, van Dam RM, Martinez-Gonzalez MA, et al. Prospective study of dietary energy density and weight gain in women. Am J Clin Nutr. Sep 2008;88(3):769-777.

14. Liu S, Willett WC, Manson JE, et al. Relation between changes in intakes of dietary fiber and grain products and changes in weight and development of obesity among middle-aged women. Am J Clin Nutr. Nov 2003;78(5):920-927.

15. Schatzkin A, Mouw T, Park $\mathrm{Y}$, et al. Dietary fiber and whole-grain consumption in relation to colorectal cancer in the NIH-AARP Diet and Health Study. Am J Clin Nutr. May 2007;85(5):1353-1360.

16. Freudenheim JL. Study design and hypothesis testing: issues in the evaluation of evidence from research in nutritional epidemiology. Am J Clin Nutr. Jun 1999;69(6):1315S-1321S.

17. Astrup A, Ryan L, Grunwald GK, et al. The role of dietary fat in body fatness: evidence from a preliminary meta-analysis of ad libitum low-fat dietary intervention studies. Br J Nutr. Mar 2000;83 Suppl 1:S25-32.

18. Brinkworth GD, Noakes M, Buckley JD, et al. Long-term effects of a very-low-carbohydrate weight loss diet compared with an isocaloric low-fat diet after 12 mo. Am J Clin Nutr. Jul 2009;90(1):23-32.

19. Tay J, Brinkworth GD, Noakes M, et al. Metabolic effects of weight loss on a very-low-carbohydrate diet compared with an isocaloric high-carbohydrate diet in abdominally obese subjects. J Am Coll Cardiol. Jan 1 2008;51(1):59-67.

20. Solum TT, Ryttig KR, Solum E, et al. The influence of a high-fibre diet on body weight, serum lipids and blood pressure in slightly overweight persons. A randomized, double-blind, placebo-controlled investigation with diet and fibre tablets (DumoVital). Int J Obes. 1987;11 Suppl 1:67-71.

21. Rosenbaum M, Sy M, Pavlovich $K$, et al. Leptin reverses weight loss-induced changes in regional neural activity responses to visual food stimuli. J Clin Invest. Jul 2008;118(7):2583-2591.

22. St-Pierre DH, Rabasa-Lhoret $\mathrm{R}$, Lavoie ME, et al. Fiber intake predicts ghrelin levels in overweight and obese postmenopausal women. Eur J Endocrinol. Jul 2009;161(1):65-72.

23. Teegarden SL, Bale TL. Effects of stress on dietary preference and intake are dependent on access and stress sensitivity. Physiol Behav. Mar 18 2008;93(4-5):713-723.

24. Lutter M, Sakata I, Osborne-Lawrence S, et al. The orexigenic hormone ghrelin defends against depressive symptoms of chronic stress. Nat Neurosci. Jul 2008;11(7):752-753.

25. Jackman MR, Steig A, Higgins JA, et al. Weight regain after sustained weight reduction is accompanied by suppressed oxidation of dietary fat and adipocyte hyperplasia. Am J Physiol Regul Integr Comp Physiol. Apr 2008;294(4):R1117-1129.

26. Goris AH, Westerterp-Plantenga MS, Westerterp KR. Undereating and underrecording of habitual food intake in obese men: selective underreporting of fat intake. Am J Clin Nutr. Jan 2000;71(1):130134.

27. Lin J, Zhang SM, Cook NR, et al. Dietary intakes of fruit, vegetables, and fiber, and risk of colorectal cancer in a prospective cohort of women (United States). Cancer Causes Control. Apr 2005;16(3):225233.

28. Buyken AE, Gunther AL, Barclay A, et al. Glycemic index in overweight development: distinguishing limited evidence from limits in evidence. Am J Clin Nutr. Jul 2009;90(1):243-244; author reply 244-246.

29. Howard BV, Manson JE, Stefanick ML, et al. Low-fat dietary pattern and weight change over 7 years: the Women's Health Initiative Dietary Modification Trial. Jama. Jan 4 2006;295(1):39-49.

30. Kaaks R, Slimani N, Riboli E. Pilot phase studies on the accuracy of dietary intake measurements in the EPIC project: overall evaluation of results. European Prospective Investigation into Cancer and Nutrition. Int J Epidemiol. 1997;26 Suppl 1:S26-36.

31. Riboli E, Hunt KJ, Slimani N, et al. European Prospective Investigation into Cancer and Nutrition (EPIC): study populations and data collection. Public Health Nutr. Dec 2002;5(6B):1113-1124. 
32. Slimani N, Deharveng G, Charrondiere RU, et al. Structure of the standardized computerized 24-h diet recall interview used as reference method in the 22 centers participating in the EPIC project. European Prospective Investigation into Cancer and Nutrition. Comput Methods Programs Biomed. Mar 1999;58(3):251-266.

33. M AM, Pera G, Agudo A, et al. Cereal fiber intake may reduce risk of gastric adenocarcinomas: The EPIC-EURGAST study. Int J Cancer. Oct 1 2007;121(7):1618-1623.

34. Kaaks R, Riboli E, van Staveren W. Calibration of dietary intake measurements in prospective cohort studies. Am J Epidemiol. Sep 1 1995;142(5):548-556.

35. Bedard D, Shatenstein B, Nadon S. Underreporting of energy intake from a self-administered foodfrequency questionnaire completed by adults in Montreal. Public Health Nutr. Aug 2004;7(5):675-681.

36. Voss S, Kroke A, Klipstein-Grobusch K, et al. Obesity as a major determinant of underreporting in a self-administered food frequency questionnaire: results from the EPIC-Potsdam Study. $Z$ Ernahrungswiss. Sep 1997;36(3):229-236.

37. Smith-Warner SA, Spiegelman D, Ritz J, et al. Methods for pooling results of epidemiologic studies: the Pooling Project of Prospective Studies of Diet and Cancer. Am J Epidemiol. Jun 1 2006;163(11):10531064.

38. Comuzzie AG, Allison DB. The search for human obesity genes. Science. May 29 1998;280(5368):13741377.

39. Frayling TM, Timpson NJ, Weedon MN, et al. A common variant in the FTO gene is associated with body mass index and predisposes to childhood and adult obesity. Science. May 11 2007;316(5826):889894.

40. Loos RJ, Lindgren CM, Li S, et al. Common variants near MC4R are associated with fat mass, weight and risk of obesity. Nat Genet. Jun 2008;40(6):768-775.

41. Li S, Loos RJ. Progress in the genetics of common obesity: size matters. Curr Opin Lipidol. Apr 2008;19(2):113-121.

42. Hinney A, Hebebrand J. Polygenic Obesity in Humans. Obesity Facts. 2008;1:35-42.

43. Mutch DM, Clement K. Unraveling the genetics of human obesity. PLoS Genet. Dec 29 2006;2(12):e188.

44. Schulze MB, Schulz M, Heidemann C, et al. Fiber and magnesium intake and incidence of type 2 diabetes: a prospective study and meta-analysis. Arch Intern Med. May 14 2007;167(9):956-965.

45. Rose G. Sick individuals and sick populations. Int J Epidemiol. Jun 2001;30(3):427-432; discussion 433424.

46. Pi-Sunyer FX. Glycemic index and disease. Am J Clin Nutr. Jul 2002;76(1):290S-298S.

47. Atkinson FS, Foster-Powell K, Brand-Miller JC. International tables of glycemic index and glycemic load values: 2008. Diabetes Care. Dec 2008;31(12):2281-2283.

48. Stanhope KL, Schwarz JM, Keim NL, et al. Consuming fructose-sweetened, not glucose-sweetened, beverages increases visceral adiposity and lipids and decreases insulin sensitivity in overweight/obese humans. J Clin Invest. May 2009;119(5):1322-1334.

49. Buchholz AC, Schoeller DA. Is a calorie a calorie? Am J Clin Nutr. May 2004;79(5):899S-906S.

50. Dale KS, McAuley KA, Taylor RW, et al. Determining optimal approaches for weight maintenance: a randomized controlled trial. Cmaj. May 12 2009;180(10):E39-46.

51. Brown L, Rosner B, Willett WW, et al. Cholesterol-lowering effects of dietary fiber: a meta-analysis. Am J Clin Nutr. Jan 1999;69(1):30-42.

52. Krieger JW, Sitren HS, Daniels MJ, et al. Effects of variation in protein and carbohydrate intake on body mass and composition during energy restriction: a meta-regression 1. Am J Clin Nutr. Feb 2006;83(2):260-274.

53. Manninen AH. Is a calorie a calorie? Biologically speaking, no. Am J Clin Nutr. Nov 2004;80(5):1445; author reply 1446 .

54. Feinman RD, Fine EJ. Whatever happened to the second law of thermodynamics? Am J Clin Nutr. Nov 2004;80(5):1445-1446; author reply 1446.

55. Manninen AH. Metabolic advantage of low-carbohydrate diets: a calorie is still not a calorie. Am J Clin Nutr. Jun 2006;83(6):1442-1443. 
56. Lovegrove JA, Gitau R. Personalized nutrition for the prevention of cardiovascular disease: a future perspective. J Hum Nutr Diet. Aug 2008;21(4):306-316.

57. Brownell KD, Frieden TR. Ounces of prevention--the public policy case for taxes on sugared beverages. N Engl J Med. Apr 30 2009;360(18):1805-1808.

58. Mello MM, Studdert DM, Brennan TA. Obesity--the new frontier of public health law. N Engl J Med. Jun 15 2006;354(24):2601-2610.

59. Goodpaster BH. Measuring body fat distribution and content in humans. Curr Opin Clin Nutr Metab Care. Sep 2002;5(5):481-487.

60. Ritz P, Salle A, Audran M, et al. Comparison of different methods to assess body composition of weight loss in obese and diabetic patients. Diabetes Res Clin Pract. Sep 2007;77(3):405-411.

61. Hayashi $\mathrm{K}$, Hara $\mathrm{H}$, Asvarujanon $\mathrm{P}$, et al. Ingestion of insoluble dietary fibre increased zinc and iron absorption and restored growth rate and zinc absorption suppressed by dietary phytate in rats. $\mathrm{Br} \mathrm{J}$ Nutr. Oct 2001;86(4):443-451.

62. Morin SH, Cobbold JF, Lim AK, et al. Incidental findings in healthy control research subjects using whole-body MRI. Eur J Radiol. Sep 23 2008:[Epub ahead of print].

63. Pouliot MC, Despres JP, Lemieux S, et al. Waist circumference and abdominal sagittal diameter: best simple anthropometric indexes of abdominal visceral adipose tissue accumulation and related cardiovascular risk in men and women. Am J Cardiol. Mar 1 1994;73(7):460-468.

64. Mason C, Katzmarzyk PT. Variability in Waist Circumference Measurements According to Anatomic Measurement Site. Obesity (Silver Spring). 2009;17(9):1789-1795.

65. Ascherio A, Rimm EB, Hernan MA, et al. Intake of potassium, magnesium, calcium, and fiber and risk of stroke among US men. Circulation. Sep 22 1998;98(12):1198-1204.

66. Kubena KS. Accuracy in dietary assessment: on the road to good science. J Am Diet Assoc. Jul 2000;100(7):775-776.

67. Mann J, Cummings JH, Englyst HN, et al. FAO/WHO scientific update on carbohydrates in human nutrition: conclusions. Eur J Clin Nutr. Dec 2007;61 Suppl 1:S132-137.

68. The official website of the glycemic index and GI database www.glycemicindex.com. Human Nutrition Unit, University of Sydney.

69. Jebb SA. Dietary determinants of obesity. Obes Rev. Mar 2007;8 Suppl 1:93-97.

70. Thorleifsson G, Walters GB, Gudbjartsson DF, et al. Genome-wide association yields new sequence variants at seven loci that associate with measures of obesity. Nat Genet. Jan 2009;41(1):18-24.

71. Ortega-Alonso A, Sipila S, Kujala UM, et al. Genetic influences on change in BMI from middle to old age: a 29-year follow-up study of twin sisters. Behav Genet. Mar 2009;39(2):154-164.

72. Katan MB. Weight-loss diets for the prevention and treatment of obesity. N Engl J Med. Feb 26 2009;360(9):923-925. 



\section{Summary}

Obesity is defined as a condition of excessive fat accumulation in adipose tissue, to the extent that health may be impaired. It has become a worldwide epidemic, leading to a substantial health and economic burden. Investigating what are the optimal strategies to prevent or treat obesity has become of utmost importance. Many dietary factors have been associated with change of adiposity, but findings are in general inconsistent (Chapter 1). The main aim of this thesis was to investigate to what extent dietary factors related to satiation and satiety, including dietary glycemic index (GI), glycemic load (GL), energy density (ED) and fiber intake, are associated with subsequent changes in body weight and waist circumference, a marker of abdominal obesity. The study was performed as part of the DiOGenes project (acronym for "Diet Obesity and Genes"). We used data from a large population-based prospective cohort study with participants from five countries participating in the European Prospective Investigation into Cancer and Nutrition (EPIC study).

GI is a quantitative indicator of the glycemic quality of carbohydrate-containing foods. It is measured as the incremental area under the blood glucose response curve (IAUC) of a test food as a percentage of the IAUC caused by a reference food, which is either glucose or white bread. Both test and reference foods should contain an equal amount of available carbohydrates. Usually, this is 50 gram or, in case of lowcarbohydrate foods, 25 gram. GI is a rather new concept proposed in the early 1980s, but much of the etiological research did not start until the late 1990's when GL, a measure of the entire glycemic burden of a food by combining both the quality and quantity of carbohydrates, was introduced. To better understand the GI concept, a comprehensive literature review on its physiological mechanisms and observed health impacts was performed (Chapter 2). Our main conclusion from this review is that it is plausible that low GI foods favorably influence the management and prevention of type 2 diabetes, obesity, cardiovascular diseases, and certain cancers. However, findings are far from consistent.

In the EPIC study, habitual diets were assessed by using food frequency questionnaires (FFQs), which were not specially designed to measure dietary GI and GL and the reproducibility and validity of these measurements had never been assessed before. It is important to obtain insight into the quality of the GI and GL measurements before examining their association with disease endpoints, in our case the subsequent changes in body weight and waist circumference. Therefore, two studies were conducted to address this issue. 
Firstly, using data from two ongoing Dutch cohort studies (the CoDAM study and the Hoorn study), in which habitual diet was estimated by the same FFQ as in the Dutch arms of the EPIC study, we investigated the association of GI and GL with blood concentrations of metabolic risk factors (Chapter 3). We observed that a 10 unit lower GI was associated with a 7\% higher HDL-cholesterol, 23\% lower fasting insulin, 23\% lower HOMA-IR, 10\% lower total/HDL cholesterol ratio, and 29\% lower CRP. However, no significant association was observed between GL and any of the metabolic factors under investigation. This might be due to the strong correlation between GL and total carbohydrate intake $(r=0.97)$, meaning that the two variables were measuring the same property of the diet. It was therefore difficult to detect any extra effect of GL on top of the impact of total carbohydrates. These findings support the hypothesis of a beneficial role of low GI diets in preventing the metabolic syndrome, insulin resistance, type 2 diabetes and cardiovascular diseases. More importantly, they may also suggest a good validity of GI measured by this FFQ.

Secondly, with the original data used to validate the Dutch EPIC FFQ in terms of the intake of total energy, food groups (i.e. breads, cereals, and potatoes) and nutrients (i.e. total carbohydrates and dietary fiber), we examined the reproducibility and relative validity of GI and GL (Chapter 4). The interclass correlation coefficients between the three repeated FFQ measurements of GI and GL were 0.78 and 0.74 respectively, which indicated a good reproducibility. Correlation coefficients between the FFQ measurements and the weighted averages of twelve 24-hour dietary recalls were 0.63 for both GI and GL, indicating a satisfactory relative validity.

Studies presented in chapter 5, 6 and 7 were conducted among 89,432 men and women. They came from six study centers in five European countries. On average, participants were 53 years old at baseline and were followed for 6.5 years. Chapter 5 is about the main effects of dietary GI and GL on subsequent changes in body weight and waist circumference. Our hypothesis was that there would be a positive association between GI, GL and subsequent gain in body weight and waist circumference. This was based on the literature showing that low GI foods are slowly digested and absorbed, thus can stimulate a higher satiation and satiety leading to a decreased total energy intake and promoting a healthy weight. Overall, in our study, weight change was not significantly associated with either GI or GL. However, the positive association between GI, not GL, and annual waist circumference change was statistically significant. Participants with higher GI of 10 units gained on average 0.19 $\mathrm{cm}$ /year more in their waist circumference than those with lower GI. The lack of association between GI and weight change may be due to the under-reporting of energy intake, which might be more weight-related than waist circumference-related. The lack of association of GL with both weight and waist circumference change may be, as above-mentioned, due to the close correlation between GL and total carbohydrate intake $(\mathrm{r}=0.98)$.

Chapter 6 focuses on dietary ED in relation to subsequent changes of body weight and waist circumference. Dietary ED is defined as the energy content per unit 
weight of food $(\mathrm{kcal} / \mathrm{g})$. Because people tend to eat a similar volume of food to reach satiation and satiety, energy dense foods could cause passive over-consumption in terms of energy intake. However, there is a lack of conclusive evidence from longterm cohort studies on the beneficial role of low ED in the prevention of subsequent weight and waist circumference gain. This might be due to variations in the methodology used to calculate dietary ED. We calculated ED as the energy provided by foods divided by the total weight of foods. Beverages were not included in the calculation based on evidence showing that 1) beverages lower ED disproportionately; 2) energy from drinks has only transient effects on satiation and does not influence habitual energy intake; 3 ) beverage intake is highly variable and difficult to be estimated by any habitual diet assessment method. Overall, we did not observe a significant association between ED and weight change, although $1 \mathrm{kcal} / \mathrm{g}$ ED was positively and significantly associated with $0.09 \mathrm{~cm} /$ year of waist circumference change. Like for GI, the lack of association between ED and weight change may be due to the under-reporting of total energy intake.

Although a beneficial role of high fiber intake in the prevention of weight and waist circumference gain has been generally accepted, limited data is available on whether the impact of fiber varies according to its food sources. Therefore, in chapter 7, we analyzed the associations of total fiber, cereal fiber and fruit and vegetable fiber with subsequent changes of body weight and waist circumference. We found that total fiber and cereal fiber were inversely associated with weight change (-39 and -77 $\mathrm{g} /$ year respectively for $10 \mathrm{~g}$ fiber), but not fruit and vegetable fiber $(2 \mathrm{~g} / \mathrm{year}$ for $10 \mathrm{~g}$ fiber). However, all these three types of fiber were inversely associated with changes in waist circumference with a similar magnitude $(-0.08,-0.10$, and $-0.08 \mathrm{~cm} /$ year respectively for $10 \mathrm{~g}$ fiber). The protective effect of cereal fiber on weight gain was more pronounced as compared to fruit and vegetable fiber. Several explanations could be responsible for this, including misreporting of fruits and vegetables, especially among those who had lower intake or who were obese; extra protective effects of whole-grain, which is the main source of cereal fiber and includes other components such as resistant starch, phytoestrogens, polyphenols, and antioxidants; and the unique influences of specific cereal fiber components such as cellulose.

All these observed associations confirm some, but not all, of the previous findings in the literature and suggest a beneficial role of low GI, high fiber, low ED diets in the prevention of excessive weight and waist gain. The small effect sizes observed may, at least partly, be due to the under-reporting of dietary intake, which is more pronounced among obese individuals. This notion was supported by the (trend of) stronger positive associations between ED and changes of weight and waist circumference in participants with a healthy BMI than in overweight or obese participants $(1 \mathrm{kcal} / \mathrm{g}$ ED was associated with 29 vs. - $103 \mathrm{~g} / \mathrm{year}$ of weight change and 0.17 vs. $0.04 \mathrm{~cm} /$ year of waist circumference change) (Chapter 6). Heterogeneity across study centers was significant in most of the associations under investigation. The exact cause is unknown but many potential factors such as different 
methodologies used to collect dietary exposures and anthropometrics, underreporting of energy intake, and different sources of study population in different centers may partially explain the heterogeneity across study centers. (Chapter 5, 6 and 7)

In chapter 8, we performed a case-cohort study exploring the associations of candidate gene variants (single nucleotide polymorphisms; SNPs) in the hypothalamic pathway with subsequent changes of body weight and waist circumference. We focused on the hypothalamic pathway because of its critical role in the regulation of satiation, satiety and thus energy intake. The potential interactions between these SNPs and GI were also investigated, given the possible impacts of dietary GI on satiation and satiety. Overall, none of the 123 SNPs in 15 candidate genes had a significant main effect on changes in weight or waist circumference. However, the interaction between GI and SNP rs7180849, near the neuromedin $\beta$ gene $(N M B)$ reached statistical significance $\left(P=3 \times 10^{-5}\right.$ and $\left.5 \times 10^{-5}\right)$. The associations between GI and subsequent changes of body weight and waist circumference were stronger in participants carrying the minor allele. This finding, when confirmed, implies that consuming low GI diets might be of special importance for minor allele carriers of this SNP.

In chapter 9, the main findings of this thesis are summarized and their interpretation, methodological issues and public health relevance are discussed. In addition, recommendations for future research are addressed. Overall, the findings presented in this thesis support the current recommendation of consuming low ED and high fiber foods to prevent obesity. Based on our own findings on GI, as well as those from the literature, we think that it may be appropriate to recommend a low GI diet for the prevention of (abdominal) obesity. However, more research is needed to investigate the association of GI, and also GL, with obesity and obesity-related chronic diseases, as well as their interactions with genetic variants. 


\section{Samenvatting}

Obesitas is een chronische ziekte waarbij een overmatige vetstapeling in het lichaam aanleiding geeft tot gezondheidsrisico's. Inmiddels is obesitas een wereldwijde epidemie geworden, die leidt tot een aanzienlijke last voor de gezondheid en een toename in de kosten van zorg. De beste strategiën voor het voorkómen of behandelen van obesitas zijn daarom op dit moment belangrijke onderwerpen voor onderzoek. Specifieke voedingsfactoren zouden in principe kunnen bijdragen aan het voorkómen van obesitas, maar de resultaten zijn tot nu toe over het algemeen inconsistent. De belangrijkste doelstelling van dit proefschrift was om te onderzoeken in hoeverre voedingsfactoren die betrokken zijn bij de verzadiging tijdens en tussen de maaltijden, gerelateerd zijn aan veranderingen in lichaamsgewicht en middelomtrek (als maat voor abdominale obesitas). Om deze relaties te bestuderen hebben we gebruik gemaakt van gegevens uit de "European Prospective Investigation into Cancer and Nutrition" (EPIC) studie, een groot prospectief cohortonderzoek onder mannen en vrouwen uit vijf Europese landen. Het onderzoek zoals beschreven in dit proefschrift werd uitgevoerd als onderdeel van het DiOGenes project (een acroniem voor "Diet, Obesity and Genes").

Voedingsfactoren die betrokken zijn bij de verzadiging tijdens en tussen de maaltijden zijn onder andere glycemische index (GI), glycemische belasting (GL), energiedichtheid (ED) en voedingsvezel. GI is een kwantitatieve maat voor de snelheid waarmee het bloedglucose stijgt na consumptie van koolhydraatbevattende voedingsmiddelen. De GI wordt gedefinieerd als de toename in de oppervlakte onder de bloedsuikercurve na consumptie van een voedingsmiddel, uitgedrukt als percentage van de oppervlakte onder de bloedsuikercurve van een referentie voedingsmiddel. Het is hierbij van belang dat het te onderzoeken voedingsmiddel en het referentie voedingsmiddel een gelijke hoeveelheid koolhydraten bevat (meestal $50 \mathrm{~g}$ of $25 \mathrm{~g}$ ). De GI is een relatief nieuw concept dat begin jaren '80 werd geïntroduceerd. Pas na de invoering van GL, een maat voor de totale glycemische belasting van een voedingsmiddel waarin rekening wordt gehouden met zowel de kwaliteit als de hoeveelheid koolhydraten, is er belangstelling ontstaan voor het bestuderen van de relaties tussen GI, GL en chronische ziekten zoals obesitas en hart- en vaatziekten. Om het concept GI beter te begrijpen is een uitgebreide literatuurstudie uitgevoerd naar de fysiologische mechanismen en de geobserveerde gezondheidseffecten (Hoofdstuk 2). Op basis van de literatuur concluderen we dat het aannemelijk is dat voedingsmiddelen met een lage GI een positieve invloed hebben op de behandeling en de preventie van type 2 diabetes, obesitas, hart- en 
vaatziekten en verschillende typen kanker. Desondanks zijn de resultaten verre van consistent.

In de EPIC studie werd de gebruikelijke voeding nagevraagd met een voedselfrequentievragenlijst (FFQ). Deze vragenlijsten zijn niet specifiek ontwikkeld om de GI en GL van de dagelijkse voeding vast te stellen. Voordat de relatie met veranderingen in lichaamsgewicht en middelomtrek kan worden onderzocht, is inzicht in de validiteit en reproduceerbaarheid van de GI en GL metingen noodzakelijk. Er werden twee studies uitgevoerd om deze aspecten te bestuderen. Ten eerste onderzochten we het verband tussen GI en GL en concentraties in het bloed van cardio-metabole risicofactoren (Hoofdstuk 3). Hiervoor hebben we gebruik gemaakt van twee lopende Nederlandse onderzoeken (de CoDAM studie en de Hoorn studie) waarin de gebruikelijke voeding werd nagevraagd met dezelfde FFQ die gebruikt was in het Nederlandse deel van de EPIC studie. We vonden dat een daling van de GI met 10 eenheden gerelateerd was aan een $7 \%$ hogere HDLcholesterol waarde, een $23 \%$ lagere nuchter insulineconcentratie, een $23 \%$ lagere HOMA-IR, een 10\% lager totaal/HDL cholesterol ratio, en een $29 \%$ lagere CRPwaarde in het bloed. We vonden echter geen significant verband tussen deze risicofactoren en GL. Dit zou veroorzaakt kunnen zijn door de sterke correlatie van GL met de totale inneming van koolhydraten $(\mathrm{r}=0,97)$, wat betekent dat de twee variabelen dezelfde eigenschap van de voeding meten. Het is daarom moeilijk om een extra effect van GL te onderscheiden. Deze resultaten ondersteunen de hypothese dat een voeding met een lage GI kan bijdragen aan de preventie van het metabool syndroom, insuline resistentie, type 2 diabetes en hart- en vaatziekten. Nog belangrijker is dat deze resultaten ook suggereren dat de validiteit van deze FFQ om GI te meten goed was. In een tweede onderzoek werd met de oorspronkelijke gegevens die gebruikt waren om de Nederlandse EPIC FFQ te valideren in termen van energie en bepaalde macro- en micronutriënten, de reproduceerbaarheid en relatieve validiteit van GI en GL onderzocht (Hoofdstuk 4). De interclasscorrelatiecoëfficiënten tussen drie herhaalde FFQ metingen van GI en GL waren respectievelijk 0,78 en 0,74 , wat duidt op een goede reproduceerbaarheid. Correlatiecoëfficiënten tussen de metingen van de FFQ en de gewogen gemiddelden van twaalf 24 -uurs navragen van de voeding waren 0,63 voor zowel GI als GL, wat aangeeft dat de relatieve validiteit voldoende is.

De studies die worden gepresenteerd in hoofdstuk 5, 6 en 7 zijn uitgevoerd bij 89.432 mannen en vrouwen. $\mathrm{Zij}$ kwamen uit 6 studiecentra in 5 verschillende Europese landen. Gemiddeld waren de deelnemers 53 jaar oud aan het begin van de studie en werden ze 6,5 jaar gevolgd. Een belangrijke hypothese van het onderzoek was dat er een positief verband bestaat tussen GI en GL enerzijds en gewichtsveranderingen anderzijds. Daarom voerden we een studie uit naar de effecten van GI en GL op de veranderingen in lichaamsgewicht en middelomtrek (Hoofdstuk 5). Er werd geen significant verband gevonden tussen GI en gewichtsverandering, maar wel tussen GI en de jaarlijkse verandering in 
middelomtrek. Deelnemers waarbij de GI met 10 eenheden toenam, namen gemiddeld $0,19 \mathrm{~cm} /$ jaar meer in middelomtrek toe. Voor GL werd geen significant verband gevonden met veranderingen in gewicht of middelomtrek.

De energiedichtheid van een voedingsmiddel is gedefinieerd als de hoeveelheid beschikbare energie per gewicht van het voedingsmiddel $(\mathrm{kcal} / \mathrm{g})$. Omdat personen vaak geneigd zijn om een gelijke hoeveelheid gewicht of volume van een voedingsmiddel te eten om verzadigd te raken, kunnen energierijke voedingsmiddelen leiden tot passieve overconsumptie van de totale energieinneming. Er is echter gebrek aan overtuigend bewijs van langdurige cohortonderzoeken die de positieve rol van voedingsmiddelen met een lage energiedichtheid in de preventie van een toename in gewicht en middelomtrek kunnen bevestigen. Dit zou verklaard kunnen worden door de verschillen in methodiek waarmee de energiedichtheid van een voedingsmiddel wordt berekend. Wij berekenden de energiedichtheid als de energie van een voedingsmiddel gedeeld door het totale gewicht van het voedingsmiddel. Dranken werden niet in de berekening opgenomen, en wel om de volgende redenen: 1) dranken verlagen de energiedichtheid onevenredig; 2) de energie van dranken geeft alleen een kortdurend effect op de verzadiging tijdens een maaltijd en heeft geen effect op de gebruikelijke energie-inneming; en 3) de inneming van dranken is erg variabel en moeilijk te meten door elke methode om de gebruikelijke voeding te meten. De resultaten lieten geen significant verband zien tussen energiedichtheid en gewichtsverandering, hoewel een toename in energiedichtheid van $1 \mathrm{kcal} / \mathrm{g}$ significant was geassocieerd met een $0,09 \mathrm{~cm}$ toename in middelomtrek. Net als bij GI, zou ook hier onderrapportage van de energie-inneming de afwezigheid van een verband tussen energiedichtheid en gewichtsverandering kunnen verklaren.

Ondanks dat het algemeen geaccepteerd is dat een hoge vezel inname een gunstige rol speelt bij de preventie van overgewicht, is maar weinig bekend of vezel afkomstig uit verschillende voedingsbronnen ook verschillende effecten laten zien. Om die reden werd in hoofdstuk 7 het verband tussen totaal vezel, vezel uit graanproducten en vezel uit groente en fruit met veranderingen in lichaamsgewicht en middelomtrek bestudeerd. We vonden dat totaal voedingsvezel en vezel uit graanproducten negatief geassocieerd waren met gewichtsverandering (-39 en -77 $\mathrm{g} /$ jaar voor $10 \mathrm{~g}$ vezel), maar niet met vezel uit groente of fruit $(2 \mathrm{~g} /$ jaar voor $10 \mathrm{~g}$ vezel). Totaal vezel, vezel uit graanproducten en vezel uit groente en fruit waren allemaal negatief gerelateerd aan veranderingen in middelomtrek (respectievelijk $0,08,-0,10$ en $-0,08 \mathrm{~cm}$ per jaar voor $10 \mathrm{~g}$ vezel). Verschillende verklaringen kunnen ten grondslag liggen aan de afwezigheid van een verband tussen vezel uit groente en fruit en gewichtsverandering, waaronder selectieve onderrapportage van de groente en fruit inneming, die mogelijk sterker gerelateerd zou kunnen zijn aan gewicht dan aan middelomtrek; een additioneel beschermend effect van volkorenprodukten, de belangrijkste bron van graanvezel die ook andere mogelijk relevant componenten bevat, zoals niet-fermenteerbare voedingsvezels, phyto-oestrogenen, polyfenolen en 
anti-oxidanten; en de unieke effecten van specifieke componenten in vezels uit graanproducten zoals cellulose.

Alle geobserveerde verbanden bevestigen sommige, maar niet alle, eerdere bevindingen in de literatuur, en duiden op een positieve rol van een voeding met een lage GI, hoge vezel en lage energiedichtheid in de preventie van overmatige toename in gewicht en middelomtrek. De kleine effecten die zijn geobserveerd zouden, op zijn minst gedeeltelijk, kunnen worden toegeschreven aan de onderrapportage van de inneming van de voeding, die sterker is in deelnemers met obesitas. Deze veronderstelling wordt ondersteund door de verschillen in resultaat tussen deelnemers met en zonder overgewicht bij aanvang van de studie zoals beschreven in Hoofdstuk 6. Het verband tussen energiedichtheid en veranderingen in gewicht en middelomtrek was sterker bij deelnemers zonder overgewicht dan in deelnemers met overgewicht. Een toename in energiedichtheid van $1 \mathrm{kcal} / \mathrm{g}$ was geassocieerd met $29 \mathrm{~g} / \mathrm{jaar}$ in gewicht en $0,17 \mathrm{~cm} / \mathrm{jaar}$ in middelomtrek in de eerstgenoemde groep vs. $-103 \mathrm{~g} / \mathrm{jaar}$ en $0,04 \mathrm{~cm} / \mathrm{jaar}$ bij de deelnemers met overgewicht.

In hoofdstuk 8 voerden we een case-cohort onderzoek uit om de associaties van polymorfismen in kandidaat genen (single nucleotide polymorfismen; SNPs) in de signaalroute van de hypothalamus te onderzoek in relatie tot veranderingen in gewicht en middelomtrek. We richtten ons op de signaalroute van de hypothalamus, omdat deze een belangrijke rol speelt bij de regulatie van verzadiging en dus ook bij energie-inneming. De mogelijke interacties tussen deze SNPs en GI werden ook onderzocht, gegeven de mogelijke effecten van GI op verzadiging en energieinneming. Geconcludeerd werd dat geen van de 123 SNP's in de 15 genen die onderzocht werden een significant effect hadden op veranderingen in gewicht en middelomtrek. Echter, de interactie tussen GI en SNP rs7180849, nabij het neuromedin $\beta$ gen $(N M B)$, was statistisch significant ook na correctie voor meervoudig testen (False Discovery Rate) $\left(P=3 \times 10^{-5}\right.$ and $\left.5 \times 10^{-5}\right)$. De verbanden tussen GI en veranderingen in lichaamsgewicht en middelomtrek waren sterker in deelnemers die vaker het minst voorkomend ('minor') allel (A) bezaten. Wanneer deze bevinding wordt bevestigd betekent dat dat de consumptie van een voeding met een lage GI belangrijk zou kunnen zijn voor dragers bij het minor allel van deze SNP.

In hoofdstuk 9 worden de belangrijkste conclusies van dit proefschrift samengevat en worden de interpretatie, methodologische aspecten en de relevantie voor de volksgezondheid bediscussieerd. Daarnaast worden ook aanbevelingen voor toekomstig onderzoek gedaan. Geconcludeerd kan worden dat de bevindingen beschreven in dit proefschrift, de huidige aanbeveling om een voeding met een lage energiedichtheid en met een hoog vezelgehalte te consumeren, ondersteunen. Gebaseerd op onze eigen conclusies, alsmede op de conclusies uit de literatuur, denken wij ook dat het mogelijk is om een voeding met een lage GI aan te bevelen voor de preventie van (abdominale) obesitas. Echter, meer onderzoek is nodig om ook de associatie van GL met obesitas, en chronische ziekten die gerelateerd zijn aan 
obesitas, goed naar waarde te kunnen schatten. Interacties met genetische aanleg zouden hier ook nadrukkelijk bij betrokken moeten worden. 



\section{摘要}

肥胖是指过多的脂肪组织在体內堆积, 它是一种全球范围內的流行 病, 对人类健康造成严重的危害, 给社会带来沉重的经济负担。也正是 因为这样, 大力研究找到有效的预防或治疗肥㭌的方法已经变得迫在眉 睫。多丰的研究显示, 诸多䐣食因素与肥㭌有关, 但是总的来说这些研 究结果揫不一致, 因此泿难从中得出确丵的结论（第 1 章）。本论文的 主要目的是研究与饱食感/饱食度有关的善食因素与体重及腰围(腰围是 一个常用的反映中心性肥㭌的指标)变化的关系。这些膳食因素包括了膳 食的生糖指数 (GI) , 生糖负荷 (GL) 和䏻量密度 (ED) 以及膳食纤 维摄入量。本研究是 DiOGenes（膳食、肥㭌和基因）项目的一部分, 数据来源于欧洲癌症和营养学前瞻性队列研究 (EPIC 研究) 中的 5 个 国家。

生糖指数 (GI) 是一个反映食物中碳水化合物生糖特证的指标。某 种洔测食物的生糖指数是由该食物所引起的血糖反应曲线下面积与参考 食物所引起的相应面积的比值所决定。洔测食物和参考食物(葡萄糖或 白面包) 应包含等量的可利用的碳水化合物 (生糖碳水化合物)。通常情 况下应该是 50 克。但是如果食物的碳水化合物含量过低, 则采用 25 克。 生糖指数是在 20 世纪 80 丰代初期提出的概念, 但是直到 90 丰代末生糖负 荷 (GL) 的概念被提出之后, 大量的病因学方面的研究才逐步开展起 来。生糖负倚是一个结合食物碳水化合物的质和量, 测量食物对机体血 糖反应的总体负荷。为了更好的理解什么是生糖指数, 生糖指数各异的 食物是通过怎样的生理学机制来影响人们的身体健康, 以及可䏻影响哪 些健康指标, 我们首先进行了一个系统全面的叙述性文献综进（第2 章)。通过该综迅我们得出了如下的主要结论：选择生糖指数低的食物 有益于预防和控制川型糖尿病、肥㭌、他血管疾病以及某些癌症。但是, 揫不是所有的研究结果都支持该结论。

在EPIC研究中, 研究参与晴的膳食引惯是由食物频率表 (FFQS) 来 评价的。但是, 这些食物频率表手平是为测定膳食的生糖指数和生糖负 倚而专门设计的, 之前也从未对这些食物频率表的开现性和有效性进行 评价。在砰究生糖指数和生糖负倚与体重和腰围变化的关系之前了解它 
摘要

们经由食物频率表所测得的值的质量非常重要。因此, 我们做了如下两 个研究:

首先, 我们分析了生糖指数和生糖负倚与代谢有关风险因素的血浓 度的关系（第3章）。我们采用的数据来源于荷兰的两个正在进行中的 前瞻性队列研究 (CODAM 研究和HOOrn研究)。之所以采用这两个研 究是因为它们使用了荷兰EPIC砰究中心所用的食物频率表来调查膳食引 惯。数据分析的结果显示, 与较高膳食生糖指数者比, 膳食生糖指数低 10个单位的研究参与者有较高的高密度脂蛋白胆固醇 (7\%) 和较低的空 腹胰岛素 (23\%) 、胰岛素抵抗指数（HOMA-IR，23\%）、总胆固醇／ 高密度脂蛋白胆固醇比（10\%）及C反应蛋白（29\%）。然而，我们搼 沒有发现生糖负荷与我们所研究的任何代谢风险因素之间存在统计学上 显著的关联性。这也许是因为生糖负倚与总碳水化合物摄入量之间存在 异常紧密的相关性 $(r=0.97)$ 。这意味着这两个变量其实反映相同的 膳食特证，因此泿难想像和发现生糖负荷具有总碳水化合物所不具有的 作用。总之, 我们的有关生糖指数的研究结果支持以前的一些研究发现, 䏨低生糖指数膳食可䏻对预防代谢综合证、胰岛素抵抗、川型糖尿病和心 血管疾病有益。更重要的是, 这些研究结果也间接地说明了这个食物频 率表所测定的膳食生糖指数具有良好的有效性（第3章）。

其次, 我们检验了生糖指数和生糖负荷测定值的重复性和有效性。这 得益于荷兰EPIC研究中心所提供的验证食物频率表的原始数据, 该数据 曾经被用于验证总䏻量、食物组（如面包、谷类和土豆）和营养素（如 总碳水化合物和膳食纤维) 摄入量测定値的重复性和有效性。我们发 现。三次重复使用该食物频率表所测得的生糖指数的相关系数是 0.78 、 生糖负荷的相吴系数是 0.74 。这说明了该两项指标具有较好的重复性。 食物频率表所测得的生糖指数和生糖负荷值与 24 小时膳食回顾法所测得 的数値的加权平均值之间的相关系数是 0.63 。这显示了该食物频率表的 有效性也合符要求（第4章）。

本论文中第 $5 、 6 、 7$ 章中所涉及的研究是在 5 个欧洲国家的 6 个研究 中心的 89432 人中进行的。研究对象在基线时平均丰龄 53 岁, 随访 6 丰牛。第 5 章是研究生糖指数和生糖负荷与体重和腰围变化的关系。我 们的研究假设是: 生糖指数和生糖负倚高的研究参与者体重和腰围增加 较多。这是基于以前的研究结果, 显示与生糖指数高的食物相比, 生糖 指数低的食物比较不容易被消化和吸收, 因此会提高进食后的饱食感和 饱食度, 抑制过多的䏻量摄入，进而有利于保持健康体重。然而，我们 的研究发现, 生糖负荷与体重和腰围变化均没有显著性关系。尽管生糖 指数也与体重改变没有显著性关系, 然而它与腰围变化之间的关系达到 
了统计学意义上的显著性。膳食生糖指数高 10 个单位的研究参与者, 他们每丰的腰围增加值高 0.19 厘米。値淂一提的是, 我们发现生糖指 数与腰围变化有关但是与体重变化无关, 这可䏻与研究参与者低估他们 的实际䏻量摄入有关。曾经有研究发现，与腰围相比，体重的大小更容 易影响研究参与者, 光其是肥胖者, 过低估计和报告他们的䏻量摄入。 关于生糖负荷，它与体重和腰围变化均无显著的关系，这可䏻是由于它 与总碳水化合物之间的过度紧密相关所致 $(r=0.98)$ 。

第 6 章是关于膳食的䏻量密度 (ED) 与体重和腰围变化的关系。䏻 力密度是指每单位重量的食物所䏻提供的䏻量（千卡/克）。因为人们 趋向于吃同样重量/体积的食物以获得饱食感和饱食度, 䏻量密度高的 食物更容易导致䏻量的过度摄入。然而，长期队列研究的结果拜本完全 支持低䏻量密度膳食在预防体重和腰围增加方面的功用，这可䏻与计算 膳食䏻量密度的方法不同有关。我们计算䐣食䏻量密度是用所有食物所 提供的䏻量除以食物总重量, 饮料拜沒有包括在内。这是因为有证据显 示 1）饮料可以不成比例地降低膳食的䏻量密度；2）来源于饮料的䏻量 对饱食感只有短暂的作用，拜尔影响引惯性膳食䏻量摄入; 3) 饮料摄 入的变异较大，泿难用任何膳食习惯的评价方法进行准确估计。尽管我 们沒䏻发现䏻量密度与体重变化之间存在显著的关系, 䏻量密度高 1 千 卡/克的研究参与者的丰平均腰围增加多 0.09 厘米, 该回归系数达到了 统计学显著性。与生糖指数的情形相似，䏻量密度与体重变化无关但与 腰围变化有关可䏻是由于体重大的研究参与者过低估计他们的䏻力摄入 有关。

尽管高膳食纤维摄入在预防体重和腰围增加方面的功效已被普遍接 受，关于是否不同食物来源的膳食纤维有不同的作用这方面的研究数据 还泿少。因此在第7章，我们分析了总膳食纤维、谷类纤维、水果和䟽 菜纤维与体重和腰围变化的关系。我们发现, 总膳食纤维与谷类纤维高 的人体重增加比较少，每增加10克膳食纤维，丰体重增加分別减少39克 和77克。每增加10克水果和赫荣纤维丰体重增加增加2克，但是这个关 系沒有显著性。在腰围变化方面, 总䐣食纤维、谷类纤维、水果和疏菜 纤维均与之的关系相似: 每增加10克膳食纤维丰腰围增加分別减少 0.08、0.10和0.08厘米。这里値得说明的是，与水果和疏荣纤维相比， 增加谷类纤维摄入似乎更有益于预防体重增加。这可䏻是由于食物频率 表所测得的赦荣和水果摄入量中的误差掩盖了水果和䟽菜纤维与体重变 化的关系。因为我们知道，摄入较低者以及肥㭌晴更容易高估他们的䟽 荣水果摄入量, 而且与腰围相比体重的大小更容易影响报告的准确性。 其次, 谷类纤维主要来源于全谷类食物，其中也许包含膳食纤维以外的 
保护成份比如抗性淀粉、植物性雌激素、多酚类和抗氧化剂。还有，特 定的谷类纤维成分如纤维素也许对体重调节具有独特的影响。

我们的研究发现证实了一部分前人的研究结果, 建议低生糖指数、高 纤维、低䏻量密度膳食在预防超重和腰围加大方面的功效。总的说来， 我们检测到的回归系数比较小，这可䏻至少部分是由于膳食摄入的低报 告所造成的, 这种低报告在肥胖人群中无为明显。之所以这样推断是由 于我们在㸴究䏻量密度与体重和腰围关系时发现，正回归系数在非肥㭌 人群中比在肥㭌人群中大, 1 千卡/克䏻量密度分別与 29 克/丰和-103克 /丰体重变化及0.17厘米/丰和0.04厘米/丰腰围变化有关（第6章）。我 们的绝大部分研究结果在6个研究中心之间具有显著的差异性, 其具体 的原因不是泿清楚，但可䏻是多因素造成的结果。比如说在膳食因素和 人体测量学指标收集方法上的差异、不同的䏻量摄入低报告模式、以及 研究参与者来源的不同等等。

在第8章，我们利用一个病例队列研究来探究在下丘脑路泾上候选基 因的变异（单核苷酸多态，SNPs）与体重和腰围的变化的关系，以及这 些SNPS和生糖指数的潜在的交互作用。之所以关注下丘脑路泾是因为 它在控制饱食感和饱食度进而䏻量摄入方面的关键性作用。总的来说, 在我们所砰究的15个基因上的123个SNPS中, 没有任何一个SNP独立影 响体重和腰围的改变。然而, 生糖指数和SNP r S 7180849的交互作用具 有统计意义上的显著性（体重变化的 $P=3 \times 10^{-5}$, 腰围变化的 $P=5 \times$ $10^{-5}$ ) 。该SNP位于神经调节肽 $\beta(N M B)$ 基因上游大概 $3 K \mathrm{~Kb}$ 的位置 上。少数等位基因携带者的膳食生糖指数与体重及腰围变化的关联性更 强。这一发现如果被证实, 就意味着对携带该SNP止数等位基因的人群 来说, 选择生糖指数低的膳食具有特殊的重要性。

本论文第 9 章总结和阐释了各章节的主要发现, 手对方洁学上问题和 对公共卫生的意义进行了讨论。另外, 也对未来该领域研究的方向提出 了展望。总而言之, 我们的研究结果支持当前的“低䏻量密度和高纤维 膳食以预防肥胖”的建议。根据我们在生糖指数方面的研究结果和文献 资料来看, 我们认为推荐生糖指数低的食物以预防（中心型）肥胖也许 是适当的，尽管我们目前还需要更多的研究来理清有关生糖指数、生糖 负倚与肥㭌及其相关慢性病的关系。以及他们与遗传性变异的交互作 用。 


\section{Acknowledgements（致谢）}

This has been a long journey, over four years and from China to Europe, from Wageningen, Bilthoven to Maastricht! I thank all of those who, in different ways, have walked beside me, offering supports and encouragements, providing inputs, challenging my thinking, and teaching me to think from the other way.

Foremost, I would like to express my sincere gratitude to my promoters and copromoter. Their professional guidance and consistent support helped me to arrive at this stage. Daphne, I learnt from you how to work in a neat and organized way. Special thanks for your detailed comments and careful correction of my writing. I admire your keen eyes! Edith, your always positive attitude and enthusiasm spurred me to go on. I have grown up under your encouragement and help. Thank you for all that you have given to me. Wim, I appreciate your critical comments and constructive suggestions on my work. The kind help from Desiree and Karin is greatly appreciated too.

Besides, I am indebted to many friends and colleagues in Wageningen. Martinet, thank you for always being there to help, from work to private issues. I feel really fortunate having you as my best friend, room mate, and colleague. Thank you for being my chauffeur and I wish you and Ruben all the best. Hanneke, my "second mother", no words could express how thankful I am for the care and love you and your family have given to me. Jane, nothing will happen today if you did not write that email to me about 5 years ago. I can not thank you enough! Olga, your warm hugs always calm me down and make me feel with mom. Frederike, thanks for the accommodation during the disaster weekend. Lisa and Vanessa, thanks for the valuable contributions you have made to my work. My young PhD fellows, Akke, Antonie, Carla, Cecile, Dieuwertje, Esmee, Geert, Gerda, Gertrude, Janette, Kevin, Linda, Marieke, Marielle, Mark, Mirre, Nicolien, Ondine, Sandra, Simone, Truus,..., thank you all for the joyful moments we have spent together: the PhD tour, WE day, Time Out, Department Trip, Christmas Parties, Sinterklaas,.... You really cheered me up and made my Wageningen memories not only about papers and computers. Colleagues who have offered all kinds of generous help since I came to Wageningen in 2002, Anneleen, Brian, Cees, Dione, Ellen, Evert, Frans, Gea, Inge, Jan Burema, Jan Harryvan, Jeanne, Joop, Karen, Lidwien, Lisette, Lous, Marie, Pieter, Rosalie, Ypie, ..., please have my sincere thanks too. Bedankt to all of you!!

I also thank all the colleagues in the Center for Nutrition and Health of RIVM, from which I learnt a lot and benefit a lot. Particularly, Marieke, it's such a nice thing sharing an office with you and a pity that we did not have a chance to share a 
bedroom (-). Thanks for the spiritual supports as well as translating several of my documents including my thesis samenvatting. Janneke and Heidi, thank you for the stroopwafel and tea as well as the taste of art. You can not imagine how much that afternoon means to me. Dank je wel!

DiOGenes partners, Nita, Nick, Ruth, Vimal, Thorkild, Ann-Louise, Claus, Lars, Ann, Jytte, Rikke, Kim, Marianne, Jaakko, Karri, Heiner, Matthias, Annika, Dominique, Gianluca, Giovana, Susan, Marleen, Edwin, Rianne, ..., it was great working with you together in a great project and sharing both the fun and the pain of doing research. Wish you all the best and I hope we can cooperate in another setting in the future.

Special thanks go to Hendriek Boshuizen from RIVM, Stephen Sharp from MRC Epidemiology unit in Cambridge, and Prof. Jos Twisk from free University of Amsterdam for their help in statistics. Prof. Jennie Brand-Miller from University of Sydney and Prof. Thomas Wolever from University of Toronto, your valuable contribution in the construction of our GI table is also sincerely acknowledged.

Last but not least, Marit and Nadia, I enjoyed very much the cooperation with you. Thank you for the indispensable contribution to my work. Trudy, thank you for your friendship and help when I was in Geneva. Good luck with your PhD and I look forward to meeting you again. Ping, you have set a role model for me to dedicate to my work. Thank you and I wish you and Kaimei all the best! Zhichao, I regret that we did not know each other earlier. I benefit a lot from your advices. Thank you and let's keep contacts!

回首这一路走过的日子, 值得我毕生珍藏。有成功的喜悦, 有失败 的沮丧，有踌躇满志，也有无措访湟。亲人和朋友是我最大的动力源 泉。在此请接受我最诚挚的感谢: 感谢冠生、燕萍、建滔、宇纳、素 英、武鸣、覃玉、爱国、求㯖、华良、淑恰、纪琴、荆奇、立祯、建 落、沈乐、舒曼…在Wageningen 的陪伴。正是因为有你们, 我在瓦村 的日尒才不孤单。感谢涂舟、仲伟、佳赫、涂辛、海旭、赵健、张炽、 靜波…在千里之外的关心和鼓励。感谢孙卓、任红、国钧、劲松、冬 妮、焦鹰、孙颖、张成…氶担了我对亲人的责任和义务, 让我在异国他 乡安心学业。有道是珠玉不如善友, 你们是我一生最大的财富。

焉得谖草, 言树之背。感谢生我养我的老釜老妈, 你们 30 几丰来无 条件的付出和宠爱, 我无以回报, 你们永远健康快乐是我最大的心愿! 感谢爷爷、奶奶、怀周、怀㯖、黄冰、李崇以及大家庭里的每一位亲 人, 谢谢你们的关心、疼爱及付出, 辛苦了! 还有我的两个小宝贝，棒 棒和可心，谢谢你们给大家带来的欢笑和希望。要健健康康快快乐乐地 长大成人哦! 最后还有你, 建军, 谢谢你这么多丰来的包容与忍让。愿 今生相依相伴!

Du 怀东 2009, 12 


\section{About the Author}

\section{Curriculum Vitae}

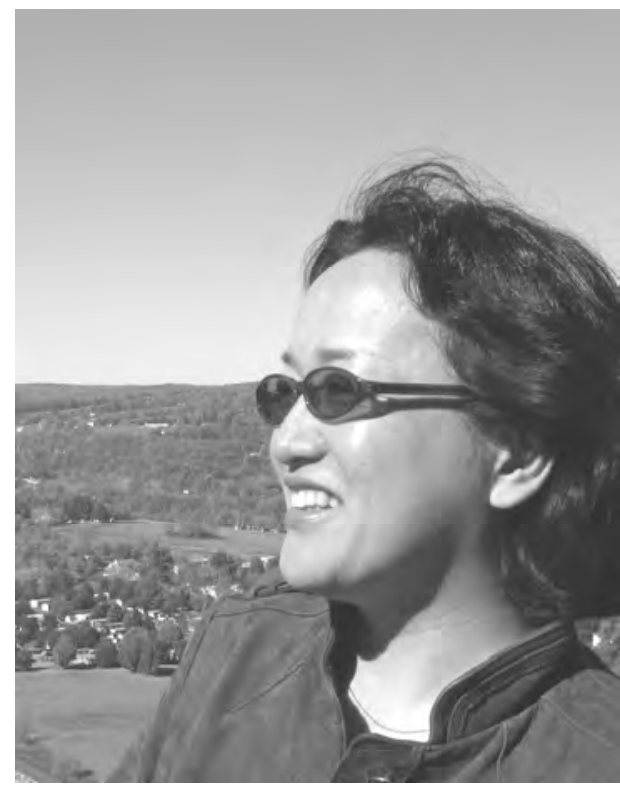

DU Huaidong was born in Liaoning, China on 24 February 1971. After she qualified in Medicine from Jinzhou Medical College in 1994, she had practiced as an Ophthalmologist for 8 years in the People's Hospital of Liaoning Province. During this period, she attended a Master degree program (1997 2000) in China Medical University with a specialization in Ophthalmology. In 2002, she started her second Master program in the Division of Human Nutrition, Wageningen University, The Netherlands. She graduated in September 2004 with a title of distinction and two specializations - Dietary Behavior \& Disease Prevention and Epidemiology \& Public Health. From October 2004 till June 2005, she worked as a program officer at the Department of International Cooperation, Ministry of Health, China. She started her $\mathrm{PhD}$ in 2005 under the joint supervision of the National Institute for Public Health and the Environment (RIVM), the Nutrition and Toxicology Research Institute Maastricht (NUTRIM) and Division of Human Nutrition, Wageningen University. Her PhD research project is the DiOGenes project which is a European project targeting on Obesity. At the Clinical Trial Service Unit of Medical Research Council (MRC) UK, DU Huaidong is currently working, as senior research assistant, on a large prospective cohort study (Kadoorie Biobank Project).

\section{Publications}

\section{As First Author}

- Du H, van der A DL, Feskens EJ. Dietary glycaemic index: a review of the physiological mechanisms and observed health impacts. Acta Cardiol. Aug 2006; 61(4):383-397.

- Du H, van der A DL, van Bakel MM, et al. Glycemic index and glycemic load in relation to food and nutrient intake and metabolic risk factors in a Dutch population. Am J Clin Nutr. Mar 2008; 87(3):655661.

- Du H, van der A DL, van Bakel MM, et al. Reproducibility and relative validity of dietary glycaemic index and glycaemic load assessed by the food-frequency questionnaire used in the Dutch cohorts of the European Prospective Investigation into Cancer and Nutrition. Br J Nutr. 2009; 102:601-604. 
- Du H, van der A DL, Ginder V, et al. Dietary energy density in relation to subsequent changes of weight and waist circumference in European men and women. Plos ONE. 2009; 4(4):e5339.

- Du H, van der A DL, van Bakel MM, et al. Dietary glycaemic index, glycaemic load and subsequent changes of weight and waist circumference in European men and women. Int J Obes (Lond). Aug 25 2009: Epub ahead of print.

- $\quad$ Du H, van der A DL, Boshuizen HC. Dietary fiber and subsequent changes of body weight and waist circumference in European men and women. Am J Clin Nutr. In Review.

\section{Other Publications (as co-author)}

- Feskens EJ, Du H. Dietary glycaemic index from an epidemiological point of view. Int J Obes (Lond) 2006; 30 Suppl 3:S66-71.

- Cust AE, Slimani N, Kaaks R, van Bakel M, Biessy C, Ferrari P, Laville M, Tjonneland A, Olsen A, Overvad K, Lajous M, Clavel-Chapelon F, Boutron-Ruault MC, Linseisen J, Rohrmann S, Nothlings U, Boeing H, Palli D, Sieri S, Panico S, Tumino R, Sacerdote C, Skeie G, Engeset D, Gram IT, Quiros JR, Jakszyn P, Sanchez MJ, Larranaga N, Navarro C, Ardanaz E, Wirfalt E, Berglund G, Lundin E, Hallmans G, Bueno-de-Mesquita HB, Du H, Peeters PH, Bingham S, Khaw KT, Allen NE, Key TJ, Jenab M, Riboli E. Dietary carbohydrates, glycemic index, glycemic load, and endometrial cancer risk within the European Prospective Investigation into Cancer and Nutrition cohort. Am J Epidemiol 2007; 166(8):912-23.

- van Bakel MM, Slimani N, Feskens EJ, Du H, Beulens JW, van der Schouw YT, Brighenti F, Halkjaer J, Cust AE, Ferrari P, Brand-Miller J, Bueno-de-Mesquita HB, Peeters P, Ardanaz E, Dorronsoro M, Crowe FL, Bingham S, Rohrmann S, Boeing H, Johansson I, Manjer J, Tjonneland A, Overvad K, Lund E, Skeie G, Mattiello A, Salvini S, Clavel-Chapelon F, Kaaks R. Methodological challenges in the application of the glycemic index in epidemiological studies using data from the European Prospective Investigation into Cancer and Nutrition. J Nutr. 2009; 139(3):568-575.

- Buijsse B, Feskens EJ, Schulze MB, Forouhi NG, Wareham NJ, Sharp S, Palli D, Tognon G, Halkjaer J, Tjonneland A, Jakobsen MU, Overvad K, van der A DL, Du H, Sorensen TI, Boeing H. Fruit and vegetable intakes and subsequent changes in body weight in European populations: results from the project on Diet, Obesity, and Genes (DiOGenes). Am J Clin Nutr. 2009;90(1):202-209.

- Forouhi NG, Sharp S, Du H, van der A DL, Halkjær J, Schulze MB, Tjønneland A, Overvad K, Jakobsen MU, Boeing H, Buijsse B, Palli D, Masala G, Feskens EJ, Sørensen TI, Wareham NJ. Dietary fat intake and subsequent weight change in adults: results from the European Prospective Investigation into Cancer and Nutrition cohorts. Am J Clin Nutr. 2009 Oct 14. [Epub ahead of print]

\section{Educational Activities}

\section{General Courses}

- $\quad$ VLAG course: PhD week, 2006 (Bilthoven, The Netherlands)

- $\quad$ Scientific Writing, 2007 (Wageningen, The Netherlands)

- PhD study tour, 2007 (To Tufts Universities, Harvard University, Cornell University, Penn State University, Monell Chemical Senses Center, Johns Hopkins University, National Institute of Health, in the USA)

- Philosophy and ethics of food sciences and technology, 2007 (Wageningen, The Netherlands) 


\section{Specific Courses or Workshops}

- $\quad$ Food Perception and Food Preference, 2005 (Wageningen, The Netherlands)

- $\quad$ Systems Biology Course: Principles of omics Data Analysis, 2005 (Nijmegen, The Netherlands)

- MSc course "Advanced Metabolism Aspects of Nutrition", 2006 (Wageningen, The Netherlands)

- $\quad$ Principles of Epidemiological Data Analysis, 2006 (Faculty: K. J Rothman; Lunteren, The Netherlands)

- Regulation of Food Intake and its Implications for Nutrition and Obesity, 2006 (Wageningen, The Netherlands)

- Dietary Influence on Blood Pressure, 2006 (Wageningen, The Netherlands)

- Longitudinal and Incomplete Data Analysis, 2006 (Faculty: G. Verbeke \& G. Molenberghs; Bilthoven, The Netherlands)

- Nutrition and Lifestyle Epidemiology, 2007 (Wageningen, The Netherlands)

- Chronic Inflammation and Obesity: Friendly or Hostile Fire, 2007 (Wageningen, The Netherlands)

- $\quad$ Food Intake Regulation. Theme: Nutrient Sensing, 2008 (Maastricht, The Netherlands)

- $\quad$ SNPs and Human Diseases, 2008 (Rotterdam, The Netherlands)

- Epigenesis and Epigenetics: Physiological Consequences of Perinatal Programming, 2008 (Wageningen, The Netherlands)

- $\quad$ Current Statistical Challenges in EPIC Europe, 2008 (Cambridge, UK)

- $\quad$ Masterclass Nutrigenomics, 2009 (Wageningen, The Netherlands)

- Translation of Genetic Variation to Gene Function in Biology and Epidemiology, 2009 (Stockholm, Sweden)

\section{Scientific Meetings}

- $\quad$ Symposium on Simple Carbohydrate Intake and Obesity, 2005 (Utrecht, The Netherlands)

- $\quad$ EuroStarch Symposium, 2005 (with poster presentation; Groningen, The Netherlands)

- Annual NuGO week, 2005 (Ichico, Italy)

- Dutch Nutrition Society (NWO) Research Meeting, 2005-2008 (with poster and oral presentation; Papendal and Deurne, The Netherlands)

- VLAG symposium: "from soil to healthy people", 2006 (with oral presentation; Wageningen, The Netherlands)

- European Congress of Obesity, 2007-2009 (with poster and oral presentation; Budapest, Hungary; Geneva, Switzerland; and Amsterdam, The Netherlands)

- Wageningen Nutritional Sciences Forum, 2009 (with oral presentation; Arhnem, The Netherlands)

- DiOGenes Project Meetings, 2005-2009 (twice per year in different locations within the Europe) 